Прилог 3.

Изјава о коришћењу

Овлашћујем Универзитетску библиотеку „Светозар Марковић“ да у Дигитални репозиторијум Универзитета у Београду унесе моју докторску дисертацију под насловом:

Zmacajodredivanja cistatinaC 2 a

procenu poremeiaja glomernlsne filtracize која је моје ауторско дело.

Дисертацију са свим прилозима предао/ла сам у електронском формату погодном за трајно архивирање.

Моју докторску дисертацију похрањену у Дигитални репозиторијум Универзитета у Београду могу да користе сви који поштују одредбе садржаніе у одабраном типу лиценце Креативне заједнице (Creative Commons) за коју сам се одлучио/ла.

1. Ауторство

2. Ауторство - некомерцијално

3. Ауторство - некомерцијално - без прераде

4. Ауторство - некомерцијално - делити под истим условима

5. Ауторство - без прераде

6. Ауторство - делити под истим условима

(Молимо да заокружите само једну од шест понуђених лиценци, кратак опис лиценци дат је на полеђини листа).

Потпис докторанда

y Беorpaay, $20 \cdot 2 \cdot 2012$

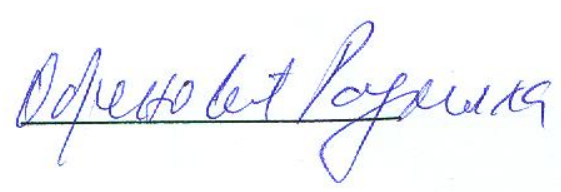


Прилог 2.

Изјава о истоветности штампане и електронске верзије докторског рада

Име и презиме аутора PALMUNA OBPEHOBUT Број уписа

Студијски програм

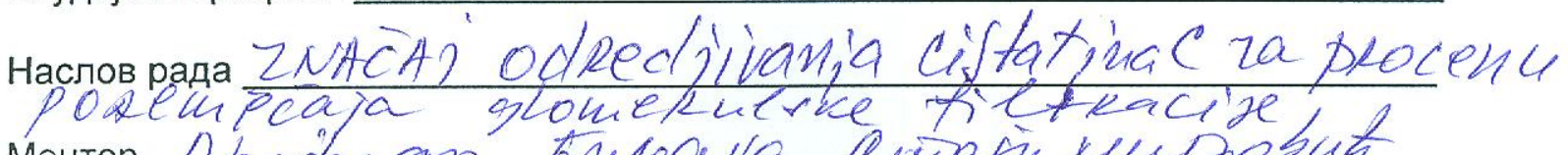
Ментор

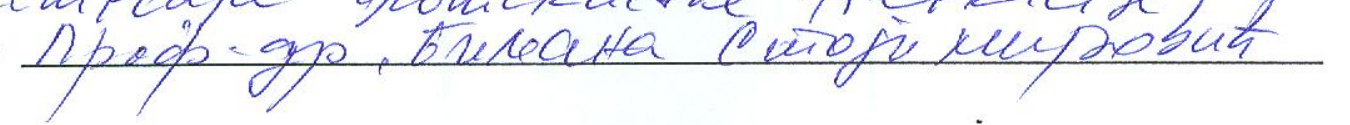

потписани OBPETHOBuћ PAsmuMt

изјављујем да је штампана верзија мог докторског рада истоветна електронској верзији коју сам предао/ла за објављивање на порталу Дигиталног репозиторијума Универзитета у Београду.

Дозвољавам да се објаве моји лични подаци везани за добијање академског звања доктора наука, као што су име и презиме, година и место рођења и датум одбране рада.

Ови лични подаци могу се објавити на мрежним страницама дигиталне библиотеке, у електронском каталогу и у публикацијама Универзитета у Београду.

Потпис докторанда

у Београду, $20.2 \cdot 2012$ 
Прилог 1.

Изјава о ауторству

потписани-а OBPEHOBut PAL Jin NA број уписа

Изјављујем

да је докторска дисертација под насловом

ZnGCAT OOREDIVANJA CISTATINAC ZA

PROCENA POREMEC'ATA GLOMERULSKE FITRACIJE

- резултат сопственог истраживачког рада,

- да предложена дисертација у целини ни у деловима није била предложена за добијање било које дипломе према студијским програмима других високошколских установа,

- да су резултати коректно наведени и - да нисам кршио/ла ауторска права и користио интелектуалну својину
других лица.

Потпис докторанда

у Београду, 20.02.2012.

Odpertolut agemen 


\section{UNIVERZITET U BEOGRADU \\ MEDICINSKI FAKULTET}

Radmila Ž. Obrenović

\section{ZNAČAJ ODREĐIVANJA CISTATINA C ZA PROCENU POREMEĆAJA GLOMERULSKE FILTRACIJE}

DOKTORSKA DISERTACIJA 


\section{UNIVERSITY OF BELGRADE \\ SCHOOL OF MEDICINE}

Radmila Z. Obrenovic

\section{THE IMPORTANCE OF DETERMINING CYSTATIN C FOR ASSESSMENT OF GLOMERULAR FILTRATION DISTURBANCE}

Doctoral Dissertation

Belgrade, 2012. 
Mentor: Prof. $d r$ Biljana Stojimirović, Univerzitet u Beogradu, Medicinski fakultet

\section{Članovi komisije:}

Prof. dr Radovan Bogdanović, Univerzitet u Beogradu, Medicinski fakultet

Prof. dr Dragan Đurić, Univerzitet u Beogradu, Medicinski fakultet

Prof. $d r$ Nada Majkić-Singh, Univerzitet u Beogradu, Farmaceutski fakultet 
Zahvaljujem se svom Mentoru Prof. dr Biljani Stojimirović na ideji, podršci, stručnim savetima, posvećenom vremenu a pre svega na neizmernom strpljenju bez koga ova disertacija ne bi bila završena.

Zahvaljujem se Prof. dr Radovanu Bogdanoviću na stručnoj pomoći i podršci pri izradi ove disertacije.

Zahvaljujem se Prof. dr Draganu Đuriću na stručnim sugestijama i smernicama za rad.

Zahvaljujem se svom učitelju, Prof. dr Nadi Majkić-Singh, za neizmernu podršku u mom naučnom i profesionalnom radu, na njenim britkim, konkretnim i dragocenim savetima što čini da se osećam privilegovanom što mi je pružena prilika da od nje učim tokom školovanja i tokom profesionalnog bavljenja medicinskom biohemijom.

Zahvaljujem se svojim kolegama iz Centra za medicinsku biohemiju Kliničkog centra Srbije koji su mi pružili podršku pri izradi ove teze.

Zahvaljujem se kolektivu biohemijske laboratorije Neurološke klinike koji mi je pružao iskrenu ljudsku podršku u mojim nastojanjima da uradim ovu disertaciju.

Zahvaljujem se svojim roditeljima koji su pored toga što su znali šta je dobro umeli to i da prenesu na svoju decu usmeravajući nas ka pravim vrednostima i čineći da se bez straha upustimo u životne i profesionalne izazove uvek sigurni da u njima imamo podršku za svaku našu odluku.

Zahvaljujem se svojoj deci i svom mužu koji svemu ovome daju poseban smisao.

Ovaj rad posvećujem mojoj Jeleni čija hrabrost inspiriše na upornost. 


\section{ZNAČAJ ODREĐIVANJA CISTATINA C ZA PROCENU POREMEĆAJA GLOMERULSKE FILTRACIJE}

\section{Rezime}

Zbog značaja koji bubreg ima u organizmu važno je rano prepoznati poremećaj njegove funkcije. Do oštećenja bubrega i do poremećaja funkcije mogu da dovedu različiti uzroci. Za procenu stanja bubrega najčešće se u kliničkoj praksi koristi kreatinin koji zavisi od pola, starosne dobi i rase, pa je zato nepouzdana za preciznu procenu JGF i to naročito kod početnih oštećenja bubrežne funkcije, a neki od ovih nedostataka mogu da budu prevaziđeni upotrebom renalnog klirensa kreatinina. Pored klirensa kreatinina primenjuje se i klirens supstanci obeleženih radioakivnim elementima, kao ${ }^{99 \mathrm{~m}}$ Tc-DTPA. Izotopske metode su reproducibilne i u visokoj korelaciji sa klirensom inulina kao zlatnim standardom za određivanje JGF. Postoji široko naučno interesovanje za utvrđivanje primenljivosti cistatina C za određivanje jačine glomerulske filtracije, kojom se $\mathrm{u}$ prvom redu procenjuju filtracioni procesi $\mathrm{u}$ glomerulu, ali se ipak nameće kao mera za praćenje najvećeg broja promena u funkciji bubrega $\mathrm{i}$ progresije njihovog oštećenja. Zbog male molekulske mase cistatin $\mathrm{C}$ se lako filtrira kroz bazalnu membranu glomerula i na taj način skoro se potpuno eliminiše iz cirkulacije posle čega se u tubulima $u$ potpunosti kataboliše i ne vraća se u cirkulaciju, što znači da njegova koncentarcija u serumu prvenstveno zavisi od jačine glomerulske filtracije.

Ispitano je u studiji preseka koja je trajala 4 godine i obuhvatila 337 ispitanika, 62 bubrežna bolesnika, 109 zdravih trudnica, 33 trudnica sa hipertenzijom izazvanom trudnoćom, 57 bolesnika sa endemskom nefropatijom, 30 bolesnika sa nefrotskim sindromom i 15 zdravih ispitanika kao i 31 bolesnik sa šećernom bolešću. Ispitivanje je sprovedeno u Kliničkom centru Srbije uz saglasnost bolesnika u skladu sa Helsinškom deklaracijom o medicinskim istraživanjima i uz odobrenje Etičkog komiteta Medicinskog fakulteta u Beogradu. Laboratorijska ispitivanja su urađena u laboratorijama Centra za medicinsku biohemiju Kliničkog centra Srbije iz preostalih alikvota krvi korišćene za rutinske laboratorijske analize. Za sva ispitivanja uzorci krvi i mokraće uzimani su ujutru. Uzorak $24 \mathrm{~h}$ urina sakupljan je od 6h ujutro prvog dana do 6h ujutro narednog dana. Uzorci venske krvi su sakupljani u vakutajnerima $(B D)$ bez aditiva, centrifugirani na $3500 \mathrm{rpm},(\approx 2000 \mathrm{~g})$ i posle separacije serum je čuvan na minus $80{ }^{\circ} \mathrm{C}$ do određivanja. Cistatin $\mathrm{C}$ u serumu je određivan PENIA metodom (Particle-Enhancesd Nephelometric Immuno-Assay) testovima firme Dade Behring (Marburg, Germany) na laserskom nefelometru (BN II Dade Behring).

Cilj rada je bio da se utvrdi da li je cistatin C pouzdan pokazatelj: 1) jačine glomerulske filtracije (JGF), tj. u kakvoj je vezi sa klirensom ${ }^{99 \mathrm{~m}}$ Tc-DTPA; 2) da se utvrdi u kakvoj je on vezi sa kreatininom u serumu i klirensom kreatinina; 3) da se utvrdi kako životna dob utiče na nivo cistatina $C$; 4) početnog oštećenja JGF i da li je pouzdaniji od kreatinina; 5) JGF kod obolelih od nefrotskog sindroma i kako proteinurija i životna dob bolesnika utiče na nivo cistatina $\mathrm{C}$ u serumu; 6) JGF kod osoba sa endemskom nefropatijom; 7) JGF kod obolelih od dijabetesa tipa 2; 8) kako gestacioni periodi trudnica sa normalnim bubrežnom funkcijom utiču na nivo cistatina $C$; 9) kako životna dob trudnica utiče na nivo cistatina $C$; 10) odnos nivoa cistatina $C$, serumskog kreatinina i klirensa kreatinina u različitim gestacionim periodima u normalnoj i u trudnoći komplikovanoj trudnoćom izazavanom hipertenzijom, da li cistatin $\mathrm{C}$ u ovoj grupi može da se koristi kao marker JGF. Da bi se ustanovilo da li cistatin C može da se primeni za procenu JGF određivan je klirens ${ }^{99 \mathrm{~m}}$ Tc-DTPA, zlatni standard za procenu JGF, serumski kreatinin i cistatin $\mathrm{C}$ kod bolesnika sa različitim bolestima bubrega. Za razliku od kreatinina, cistatin $\mathrm{C}$ i klirens

${ }^{99 m}$ Tc-DTPA ne zavise od pola bolesnika a cistatin C ne zavisi ni od starosne dobi bolesnika. Ustanovljeno je visoko slaganje vrednosti klirensa ${ }^{99 \mathrm{~m}}$ Tc-DTPA i cistatina $\mathrm{C}$, što potvrđuje da je cistatin C pouzdan pokazatelj jačine glomerulske filtracije.

Ispitivanjem kreatinina, klirensa kreatinina i cistatina $\mathrm{C}$ kod trudnica dobijeno je da se nivo kreatinina u serumu kretao u okviru referentnih vrednosti sa trendom rasta za razliku od nivoa klirensa 
kreatinina na koji nije uticala gestaciona dob. Na vrednost cistatina $\mathrm{C}$ u trudnoći značajno utiče gestaciona dob trudnica. Dobijeno je dobro slaganje vrednosti cistatina $\mathrm{C}$ i kreatinina u serumu, dok nije utvrđeno slaganje cistatina $\mathrm{C}$ i klirensa kreatinina u trudnoći osim u prvom trimestru. Ovim je pokazano da kod trudnica vrednost cistatina $\mathrm{C}$ ne odražava JGF sem u prvom trimestru. Ispitivanje uticaja životne dobi trudnica na posmatrane parametre je pokazalo da trudnice starije od 40 godina imaju značajno najviše prosečne vrednosti kreatinina i cistatina $\mathrm{C}$ u serumu, dok su vrednosti klirensa kreatinina snižavale sa starenjem trudnica. Analizom posmatranih parametara $u$ odnosu na trimestre i životnu dob trudnica pokazano je da sa starošću prosečne vrednosti cistatina $\mathrm{C}$ imaju trend rasta u prvom, drugom i trećem trimestru dok prosečne recipročne vrednosti cistatina $\mathrm{C}$ u svim trimestrima sa starošću opadaju. U sva tri trimestra vrednosti kreatinina imale su trend rasta a prosečne vrednosti klirensa kreatinina prema dobnim grupama u drugom i u trećem trimestru imale su trend snižavanja, dok su u prvom trimestru sa starošću rasle prosečne vrednosti klirensa kreatinin. Određivanjem kreatinina, klirensa kreatinina i cistatina $\mathrm{C}$ kod trudnica sa PIH nije potvrđena veza između cistatina $\mathrm{C}$ i kreatinina, ni između cistatina $\mathrm{C}$ i klirensa kreatinina kod trudnica kod kojih je prisutna trudnoćom izazvana hipertenzija. Dobijeno je da su prosečne vrednosti cistatina $\mathrm{C}$ značajno više kod trudnica sa trudnoćom izazvanom hipertenzijom u odnosu na zdrave trudnice iste gestacione dobi dok nije uočena značajna razlika vrednosti kreatinina i klirensa kreatinina. Nivo cistatina $\mathrm{C}$ raste sa starošću trudnica sa PIH, dok klirens kreatinina i kreatinin u serumu ostaju nepromenjeni. Dobijene vrednosti kreatinina, klirensa kreatinina i cistatina C kod bolesnika sa balkanskom endemskom nefropatijom pokazale su da ne postoji značajna povezanost između starosti ovih bolesnika, klirensa kreatinina i cistatina $\mathrm{C}$ dok je utvrđeno da sa starošću značajno raste nivo kreatinina $\mathrm{u}$ serumu bolesnika sa BEN. Dobijeno je dobro slaganje cistatina $\mathrm{C}$ sa klirensom kreatinina, tj. višim vrednostima cistatina $C$ odgovaraju niže vrednosti klirensa kreatinina pa se cistatina $C$ kod ovih bolesnika može korisiti za procenu JGF. Ispitivanje uticaja proteinurije na koncentraciju cistatina $\mathrm{C}$ u serumu bolesnika sa nefrotskim sindromom pokazano je da je prosečna vrednost klirensa kreatinina bila značajno niža kod bolesnika sa nefrotskim sindromom u odnosu na kontrolnu grupu dok je vrednost cistatina $\mathrm{C} \mathrm{u}$ serumu bila značajno viša u odnosu na kontrolnu grupu. Nije ustanovljena povezanost vrednosti kreatinina i cistatina $\mathrm{C}$ u serumu bolesnika sa nefrotskim sindromom i njihove životne dobi dok je ustanovljena povezanost klirensa kreatinina i životne dobi. Rezultati određivanja kreatinina, klirensa kreatinina i cistatina $\mathrm{C}$ kod bolesnika sa diabetes mellitus su pokazali da bolesnici sa DM imaju značajno različite vrednosti kreatinina i cistatina $\mathrm{C}$ u serumu u odnosu na grupe koje su formirane prema klirensu kreatinina. Kod bolesnika sa DM koji imaju klirens kreatinina ispod $60 \mathrm{ml} / \mathrm{min}$ dokazana je značajna obrnuta korelacija cistatina $\mathrm{C}$ sa klirensom kreatinina i direktna korelacija sa kreatininom. Kod bolesnika sa DM čiji je klirens kreatinina $>60 \mathrm{ml} / \mathrm{min}$ ne postoji povezanost cistatina $\mathrm{C}$ sa klirensom kreatinina $\mathrm{i}$ vrednostima kreatinina u serumu.Može se zaključiti da je cistatin C dobar pokazatelj JGF kod bolesnika sa različitim bolestima bubrega, bolesnika sa BEN, bolesnika sa nefrotskim sindromom i bolesnika sa šećernom bolešću dok je sporna njegovu primenjljivost za procenu JGF u normalnoj trudnoći.

Zaključili smo da u normalnoj trudnoći cistatin C nije pouzdan marker jačine glomerulske filtracije ali zbog njegovog porasta već od prvog trimestra može biti marker za blagovremeno uočavanje transformacije normalne trudnoće u patološku.

Ključne reči: JGF, cistatin C, kreatinin, klirens kreatinina, klirens ${ }^{99 m}$ Tc-DTPA, trudnoća, PIH, nefrotski sindrom, dijabetes, BEN.

Naučna oblast: Nefrologija

Uža naučna oblast: Medicinska biohemija

UDK BROJ: 616.611-074 (043.3) 


\title{
THE IMPORTANCE OF DETERMINING CYSTATIN C FOR ASSESSMENT OF GLOMERULAR FILTRATION DISTURBANCE
}

\begin{abstract}
Kidney failure can occur due to a number of causes. The laboratory marker that has long served as the mainstay for detecting impaired kidney function is serum creatinine. Unfortunately, serum creatinine is an insensitive marker of kidney injury, since it depends on sex, age and race. Furthermore, it does not reflect mildly diminshed renal function. Some of these shortcomings can be overcome by the creatinine clearance. However, creatinine clearance may be inaccurate because of tubular creatinine secretion and errors in specimen collection. Measurements of the renal clearance of infused tracers such as ${ }^{99 \mathrm{~m}} \mathrm{Tc}$-DTPA provide accurate measurements of GFR and correlates well with inulin clearance, which is the gold standard for determining GFR. There has been an ongoing search for improved markers for impaired renal function or injury. Cystatin $\mathrm{C}$ seems to be a promising candidate to assess GFR, but also other functional chnages in the kidney and their progression. It is produced by all nucleated cells and is small enough to be freely filtered at the glomerulus and completely removed from blood. It is then fully catabolized in the tubules, meaning that its serum concentration depends mainly on GFR.
\end{abstract}

In this cross-sectional study we aimed to: 1$)$ determine is cystatin $C$ reliable marker of GFR, by determinig its correlation with ${ }^{99 \mathrm{~m}} \mathrm{Tc}$-DTPA clearance; 2) determine the relationship between serum cystatin $\mathrm{C}$ concentration, serum creatinine and creatinine clearance; 3 ) determine the correlation between serum cystatin $\mathrm{C}$ and age; 4) determine is cystatin $\mathrm{C}$ a reliable marker of mildly diminshed renal function; 5) determine is serum cystatin $\mathrm{C}$ a reliable marker of GFR in nephrotic syndrome and how proteinuria and age influence its serum concentration; 6) determine if serum cystatin $\mathrm{C}$ is a reliable marker of renal function in nedemic nephropathy; 7) determine is serum cystatin $\mathrm{C}$ a reliable marker of renla function in nephropathy caused by type 2 diabetes; 8) determine correlation between serum cystatin $\mathrm{C}$ and gestational period in healthy pregnant women; 9) determine correlation between age and serum cystatin $\mathrm{C}$ in healthy pregnant women and 10) assess relationship between cystatin C, creatinine and creatinine clearance in different gestational period in normal and hypertensive pregnancies.

Over the period of 4 years we investigated 337 persons: 62 renal failure patients, 109 healthy pregnant women, 33 preagnant women with pregnancy induced hypertension (PIH), 57 patients with Balkan endemic nephropathy (BEN), 30 patients with nephrotic syndrome, 31 patients with type 2 diabetes and 15 healthy subjects. All individuals gave their informed consent for participation the study, accordnig to the Declaration of Helsinki. The study was approved by the Ethical Commitee of University School of Medicine in Belgrade and conducted in the Clinical Center of Serbia. Laboratory investigations were performed in the Center for Medical Biochemistry at the Clinical Center of Serbia from the remaining aliquotes of blood used for routine analyses. All blood and urine samples were taken in the morning. The 24-hour udine was collected between 6 A.M. one day and 6 A.M. the next day. Venous blood samples were collected in vacutainers (BD) without aditives, centrifuged at $3500 \mathrm{rpm}(\approx 2000 \mathrm{~g})$ and preserved at $80^{\circ} \mathrm{C}$ after separation. Cystatin $\mathrm{C}$ serum concentration was determined by the PENIA method (Particle-Enhancesd Nephelometric Immuno-Assay), using the Dade Behring (Marburg, Germany) tests, on a laser nephelometer (BN II Dade Behring).

In order to determine if cystatin $\mathrm{C}$ can be used as a marker of GFR, its correlation with ${ }^{99 \mathrm{~m}} \mathrm{Tc}-$ DTPA clearance and serum creatinine was determined in patients with different renal diseases. Unlike creatinine, cystatin $\mathrm{C}$ and ${ }^{99 \mathrm{~m}} \mathrm{Tc}$-DTPA clearance do not depend on sex, and cystatin $\mathrm{C}$ also does not depend on patients age. Serum creatinine is significantly inversely correlated with ${ }^{9 \mathrm{~m}} \mathrm{Tc}-\mathrm{DTPA}$ clearance $(p<0,001)$ and significantly correlated with serum cystatin $\mathrm{C}$ concentration $(\mathrm{p}<, 0001) .{ }^{99 \mathrm{~m}} \mathrm{Tc}-\mathrm{DTPA}$ clearance significantly correlates with serum cystatin $C$ concentration $(p<0,001)$ and serum cystatin $C$ 
rciprocal values, indicating that serum cystatin $C$ is a reliable marker of GFR. Serum creatinin was within reference levels, with mild elevation trend, during normal pregnancy. Creatinine clearance was not influenced by the gestational period in normal pregnancy. Cystatin $\mathrm{C}$ correlated significantly with gestational period $(\mathrm{p}<0,0001)$ and serum creatinine levels $(\mathrm{p}<0,0001)$ in healthy pregnant women. However, serum cystatin $\mathrm{C}$ correlated well with creatinine clearance only in the first trimester of normal pregnancy $(p>0,05)$. Therefore, serum cystatin $C$ is a reliable marker of GFR only in the first trimester of normal pregnancy. Pregnant women over 40 had significantly higher serum creatinine and cystatin $\mathrm{C}$ levels, while creatinine clearance decreased with age of pregnant women. Serum cystatin $\mathrm{C}$ and creatinine levels exhibit steady rise over the first, second and third trimester of normal pregnancy. Creatinine clearance showed rise in the first and then steady decrease in the second and third trimester of normal pregnancy. Serum cystatin C levels were significantly higher in women with PIH then in healthy pregnant women $(\mathrm{p}<0,004)$ in the same gestational period. Cystatin $\mathrm{C}$ levels rise with age in $\mathrm{PIH}$, while serum creatinine and creatinine clearance remain consant. No significant correlation was found between serum creatinine, cystatin $\mathrm{C}$ and creatinine clearance in pregnant women with PIH. No significant difference was observed in serum creatinine and creatinine clearance between these groups of women. No significant correlation was found between cystatin $\mathrm{C}$ and creatinin clearance and age in patients with BEN, while serum creatinine rose significantly with age in these patients. Serum cystatin $C$ correlated well with creatinine clearance in patients with BEN $(p<0,05)$, thus implying that cystatin $C$ is a reliable marker of GFR in this group of patients. Creatinine clearance was significantly lower in patients with nephrotic syndrome then in controls, while serum cystatin $\mathrm{C}$ levels were significantly higher in proteinuric patients then in the control group $(\mathrm{p}<0,05)$. No correlation was observed between serum creatinine, cystatin $\mathrm{C}$ and age in patients with nephrotic syndrome. However, significant correlation was found between creatinine clearance and age in this group ofpatients. Cystatin $\mathrm{C}$ was significantly reversely correlated with creatinine clearance $(p<0,0001)$ and directly correlated with serum creatinine $(p<0,0001)$ in diabetic patients with creatinine clearance under $60 \mathrm{ml} / \mathrm{min}$. No correlation between these parameters was found in diabteic patients with creatinine clearance over $60 \mathrm{ml} / \mathrm{min}$. Cystatin $\mathrm{C}$ is a reliable marker of renal function in different renal diseases. However, it is not a good marker of GFR in normal pregnancy, but it can be used for early detection of transition of normal into pathologic pregnancy.

Key words: GFR, cystatin C, creatinine, creatinine clearance, ${ }^{99 m}$ Tc-DTPA clearance, pregnancy, PIH, nephrotic syndrome, diabetes, BEN

Scientific field: Nephrology

Scientific subfield: Medical biochemistry

UDC NUMBER: 616.611-074 (043.3) 


\section{SADRŽAJ}

1. UVOD 1

1.1. GRAĐA I FUNKCIJA BUBREGA 1

1.1.1. Značaj ranog otkrivanja oboljenja bubrega 5

1.2. JAČINA GLOMERULSKE FILTRACIJE 6

1.3. METODE ZA MERENJE JAČINE GLOMERULSKE FILTRACIJE 8

1.3.1. Metode zasnovane na klirensu neizotopa i radionukleida 9

1.3.2. Metode zasnovane na serumskom kreatininu 10

1.3.3. Klirens kreatinina 14

1.3.4. Endogeni filtracioni marker - cistatin C 15

2. CILJ RADA 23

3. ISPITANICI I METODE 24

$\begin{array}{ll}\text { 3.1. ISPITANICI } & 24\end{array}$

3.2. METODE ISPITIVANJA 26

3.2.1. Određivanje koncentracije kreatinina 26

3.2.2. Određivanje koncentarcije cistatina C 26

3.2.3. Određivanje ukupnih proteina u urinu 27

3.2.4. Određivanje JGF primenom dinamske scintigrafije $\quad 27$

3.3. STATISTIČKA ANALIZA 28

$\begin{array}{lr}\text { 4. REZULTATI } & 29\end{array}$

4.1. REZULTATI ODREĐIVANJA KLIRENSA ${ }^{99 m}$ Tc-DTPA, KREATININA I CISTATINA C KOD BOLESNIKA SA RAZLIČITIM BOLESTIMA BUBREGA 29

4.1.1. Vrednosti klirensa ${ }^{99 \mathrm{~m}}$ Tc-DTPA, koncentracije kreatinin i cistatina $\mathrm{C} \mathrm{u}$ serumu i recipročne vrednosti cistatina $\mathrm{C}$ kod bubrežnih bolesnika 
4.1.2. Korelacija nivoa klirensa ${ }^{99 \mathrm{~m}}$ Tc-DTPA sa koncentracijama kreatinina i cistatina $\mathrm{C}$ u serumu i recipročnim vrednostima cistatina $\mathrm{C}$ pacijenata sa $\mathrm{BB}$

4.1.3. Korelacija nivoa klirensa ${ }^{99 \mathrm{~m}} \mathrm{Tc}-\mathrm{DTPA}$ sa koncentracijama kreatinina i cistatina $\mathrm{C}$ u serumu i recipročnim vrednostima cistatina $\mathrm{C}$ kod osoba muškog pola

4.1.4. Korelacija klirensa ${ }^{99 \mathrm{~m}}$ Tc-DTPA sa koncentracijama kreatinina i cistatina $\mathrm{C}$ u serumu i recipročnim vrednostima cistatina $\mathrm{C}$ kod osoba ženskog pola

4.1.5. Uticaj životne dobi na vrednosti klirensa ${ }^{99 \mathrm{~m}}$ Tc-DTPA, kreatinina, cistatina $\mathrm{C}$ i recipročnu vrednost cistatina $\mathrm{C}$

\subsection{REZULTATI ODREĐIVANJA KREATININA, KLIRENSA KREATININA I} CISTATINA C KOD TRUDNICA

4.2.1. Distribucija trudnica prema gestacionom periodu

4.2.2. Distribucija vrednosti kreatinina, klirensa kreatinina, cistatina C i recipročne vrednosti cistatina $\mathrm{C}$ kod trudnica različite gestacione dobi

4.2.3. Korelacija gestacionog doba trudnica sa vrednostima kreatinina, klirensa kreatinina, cistatina $\mathrm{C}$ i recipročnim vrednostima cistatina $\mathrm{C}$

4.2.4. Međusobna korelacija dobijenih vrednosti kreatinina, klirensa kreatinina, cistatina $\mathrm{C}$ i recipročne vrednosti cistatina $\mathrm{C}$ kod trudnica

4.2.5. Korelacija kreatinina, klirensa kreatinina, cistatina $\mathrm{C}$ i recipročne vrednosti cistatina $\mathrm{C}$ kod trudnica u prvom trimestru

4.2.5.1. Analiza ROC (Receiver Operating Characteristic) krive trudnica u prvom trimestru

4.2.6. Korelacija nivoa kreatinina, klirensa kreatinina, cistatina $\mathrm{C}$ i recipročne vrednosti cistatina $\mathrm{C}$ dobijenih kod trudnica $\mathrm{u}$ drugom trimestru

4.2.6.1. Analiza ROC (Receiver Operating Characteristic) krive trudnica u drugom trimestru 
4.2.7. Korelacija nivoa kreatinina, klirensa kreatinina, cistatina $C$ i recipročne vrednosti cistatina $\mathrm{C}$ kod trudnica u trećem trimestru

4.2.7.1. Analiza ROC (Receiver Operating Characteristic) krive trudnica $\mathrm{u}$ trećem trimestru

4.2.8. Prosečne vrednosti klirensa kreatinina, kreatinina i cistatina C kod trudnica u odnosu na životnu dob trudnica

4.2.8.1. Uticaj životne dobi trudnica na nivo kreatinina 57

4.2.8.2. Uticaj životne dobi trudnica na vrednosti klirensa kreatinina $\quad 59$

4.2.8.3. Uticaj životne dobi trudnica na nivo cistatina C 61

4.2.8.4. Uticaj životne dobi trudnica na recipročnu vrednost cistatina C 63

4.2.9. Distribucija cistatina $\mathrm{C}$ i drugih određivanih parametara u odnosu na trimestar i dobne grupe

4.2.9.1. Distribucija vrednosti cistatina $\mathrm{C}$ zavisno od trimestra i dobne grupe trudnica

4.2.9.2. Distribucija recipročnih vrednosti cistatina $\mathrm{C}$ zavisno od trimestra i dobne grupe

4.2.9.3. Distribucija koncentracija kreatinina zavisno od trimestra i dobne grupe

4.2.9.4. Distribucija klirensa kreatinina zavisno od trimestra i dobne grupe trudnica

\subsection{REZULTATI ODREĐIVANJA KREATININA, KLIRENSA KREATININA I}

4.3.1. Distribucija vrednosti kreatinina, klirensa kreatinina, cistatina C i recipročne vrednosti cistatina $\mathrm{C}$ kod trudnica sa $\mathrm{PIH}$

4.3.2. Međusobna korelacija nivoa kreatinina, klirensa kreatinina, cistatina

$\mathrm{C}$ i recipročne vrednosti cistatina $\mathrm{C}$ dobijenih kod trudnica sa $\mathrm{PIH}$ 
4.3.3. Korelacija nivoa kreatinina, klirensa kreatinina, cistatina $\mathrm{C}$ i recipročne vrednosti cistatina $\mathrm{C}$ dobijenih kod trudnica sa PIH prema vrednostima dobijenih kod trudnica u III trimestru

4.3.3.1. Receiver Operating Characteristic Curve kod trudnica sa PIH u odnosu na III trimestar

4.3.4. Prosečne vrednosti klirensa kreatinina, kreatinina i cistatina $\mathrm{C}$ kod trudnica sa PIH u odnosu na životnu dob

4.3.4.1. Uticaj životne dobi na nivo kreatinina u serumu trudnica sa PIH 76

4.3.4.2. Uticaj životne dobi na nivo klirensa kreatinina trudnica sa PIH 77

4.3.4.3. Uticaj životne dobi na nivo cistatina $\mathrm{C}$ u serumu trudnica sa $\mathrm{PIH}$ 79

4.3.4.4. Uticaj životne dobi na recipročnu vrednost cistatina $\mathrm{C}$ trudnica sa PIH

4.4. REZULTATI ODREĐIVANJA KREATININA, KLIRENSA KREATININA I CISTATINA C KOD BOLESNIKA SA BALKANSKOM ENDEMSKOM NEFROPATIJOM

4.4.1. Distribucija vrednosti kreatinina, klirensa kreatinina, cistatina C i recipročne vrednosti cistatina $\mathrm{C}$ kod bolesnika sa BEN

4.5. UTICAJ PROTEINURIJE NA KONCENTRACIJU CISTATINA C U SERUMU KOD BOLESNIKA SA NEFROTSKIM SINDROMOM

4.5.1. Uticaj životne dobi bolesnika sa nefrotskim sindromom na nivo kreatinina, klirensa kreatinina, cistatina $\mathrm{C}$ i recipročnu vrednost cistatina $\mathrm{C}$

4.6. REZULTATI ODREĐIVANJA KREATININA, KLIRENSA KREATININA I CISTATINA C KOD BOLESNIKA SA DIABETES MELLITUS

4.6.1. Uticaj životne dobi na vrednosti klirensa kreatinina, kreatinina, cistatina C i recipročnu vrednost cistatina $\mathrm{C}$ kod bolesnika sa $\mathrm{DM}$

4.6.2. Vrednosti kreatinina, klirensa kreatinina, cistatina $\mathrm{C}$ i recipročne vrednosti cistatina C kod bolesnika sa DM 
4.6.3. Korelacija cistatina $\mathrm{C}$ u serumu sa klirensom kreatinina, koncentracijom kreatinina i recipročnim vrednostima cistatina $\mathrm{C}$ kod bolesnika sa DM

4.6.4. Korelacija cistatina $\mathrm{C}$ u serumu sa klirensom kreatinina, koncentracijom kreatinina i recipročnim vrednostima cistatina $\mathrm{C}$ kod bolesnika sa DM zavisno od grupe

5. DISKUSIJA

5.1. VREDNOSTI KLIRENSA ${ }^{99 \mathrm{~m}}$ Tc-DTPA, KREATININA I CISTATINA C KOD BOLESNIKA SA RAZLIČITIM BOLESTIMA BUBREGA

5.2. VREDNOSTI ODREĐIVANJA KREATININA, KLIRENSA KREATININA I CISTATINA C KOD TRUDNICA

5.3. VREDNOSTI KREATININA, KLIRENSA KREATININA I CISTATINA C KOD TRUDNICA SA PIH

5.4. VREDNOSTI KREATININA, KLIRENSA KREATININA I CISTATINA C KOD BOLESNIKA SA BALKANSKOM ENDEMSKOM NEFROPATIJOM

5.5. UTICAJ PROTEINURIJE NA KONCENTRACIJU CISTATINA C U SERUMU BOLESNIKA SA NEFROTSKIM SINDROMOM

5.6. VREDNOSTI KREATININA, KLIRENSA KREATININA I CISTATINA C KOD BOLESNIKA SA DIABETES MELLITUS

6. ZAKLJUČCI 


\section{BIOGRAFIJA}

Radmila Obrenović, rođena Rakić (otac Živojin, majka Dragica ) rođena je 30. jula 1959. god. u Milutovcu gde je završila osnovnu školu. Srednju školu je završila sa odličnim uspehom u Čačku 1978. godine $\mathrm{i}$ iste je upisala Farmaceutski fakultet u Beogradu. Kao student bavila se naučnim radom u Institutu za organsku hemiju gde je radila u okviru projekta „Sinteza novih lekovitih supstanci“‘. Diplomirala je 5. januara 1983. godine i zaposlila se u Zdravstvenom centru u Kruševcu. Magistarsku tezu pod nazivom „Uticaj konzervansa i površinski aktivnih materija na osobine gelova natrijumkarboksimetilceluloze“ odbranila je 1991. god. i stekla akademsku titulu magistar nauka.

Specijalizaciju iz medicinske biohemije sa odličnim uspehom završila je 1992. god. i odbranila specijalistički rad pod nazivom „Odredjivanje referentnih vrednosti za apolipoproteine A I i B turbidimetrijskom metodom“ na Farmaceutskom fakultetu u Beogradu.

Po završetku specijalizacije radi u Odeljenju za laboratorijska ispitivanja u Zdravstvenom centru Kruševac. Marta meseca 1995. godine prelazi u KCS u Institut za medicinsku biohemiju. Do 1999. god. radi u biohemijskoj laboratoriji Urgentnog centra a zatim u biohemijskoj laboratoriji Instituta za endokrinologiju.

Na mesto načelnika biohemijske laboratorije Instituta za neurologiju postavljena je 2000 . god a 2003. god. je imenovana za načelnika Centra za kliničku laboratorijsku dijagnostiku. Sada je pomoćnik direktora Centra za medicinsku biohemiju Kliničkog centra Srbije i načelnik Odeljenja Centra za medicinsku biohemiju na Neurološkoj klinici. Pored uspešnog stručnog rada uporedo se bavi i naučnim radom i birana je u zvanje istraživač saradnik na Farmaceutskom fakultetu. Stručni naziv Primarijus dobila je 2003. godine.

Bila je saradnik-istraživač u projektu 1260 Ministarstva nauke, tehnologije i zaštite životne sredine, pod rukovodstvom Prof. dr. Nade Majkić-Singh. Učestvovala je u organizaciji više naučnih i stručnih skupova iz oblasti medicinske biohemije. Saradjuje sa velikim brojem istraživača iz različitih oblasti a najviše iz medicine i farmacije. Član je Izvršnog Odbora Društva medicinskih biohemičara Srbije i predsednik Sekcije za medicinsku biohemiju Farmaceutskog društva Srbije. Član je: Upravnog odbora Komore biohemičara Srbije, Republičke Stručne Komisije za medicinsku i kliničku biohemiju, komisije za polaganje stručnog ispita za 
farmaceute-medicinske biohemičare i više komisija i radnih tela u Kliničkom centru Srbije. U svojstvu Ocenjivača učestvuje u akreditaciji zdravstvenih ustanova u Republici Srbiji.

Autor je dela publikacije „Proteinurija“ urednika Biljane Stojimirović u izdanju Medicinskog fakulteta u Beogradu 2008.godine. Takođe je saradnik u delu publikacije „Glavobol in nevropatska bolečina s kliničkim primeri“, urednika Bojane Žvan i Marjana Zaletel 2011. Ljubljana. Kao autor ili koautor objavila je 12 radova u celini u CC časopisima, 26 radova u Medline časopisima i preko 80 sažetaka koji su štampani u stranim i domaćim časopisima. Najveći broj radova se bavi problemima iz oblasti nefrologije, endokrinologije, kardiologije, neurologije i medicinske biohemije.

Objavljivanjem većeg broja naučnih i stručnih radova, pokazala je i značajnu sposobnost i interesovanje za naučno istraživački rad, kojim se kontinuirano bavi još od studentskih dana. Udata je i ima dve kćerke. 


\section{U V O D}

\subsection{GRAĐA I FUNKCIJA BUBREGA}

Bubrezi su parni organ koji se nalaze u retroperitonealnom prostoru postavljeni sa obe strane kičmenog stuba. Desni bubreg potiskuje jetra, te se on nalazi u odnosu na levi bubreg malo niže. Bubreg ima oblik zrna pasulja, težina mu je oko 140 do 150 grama.

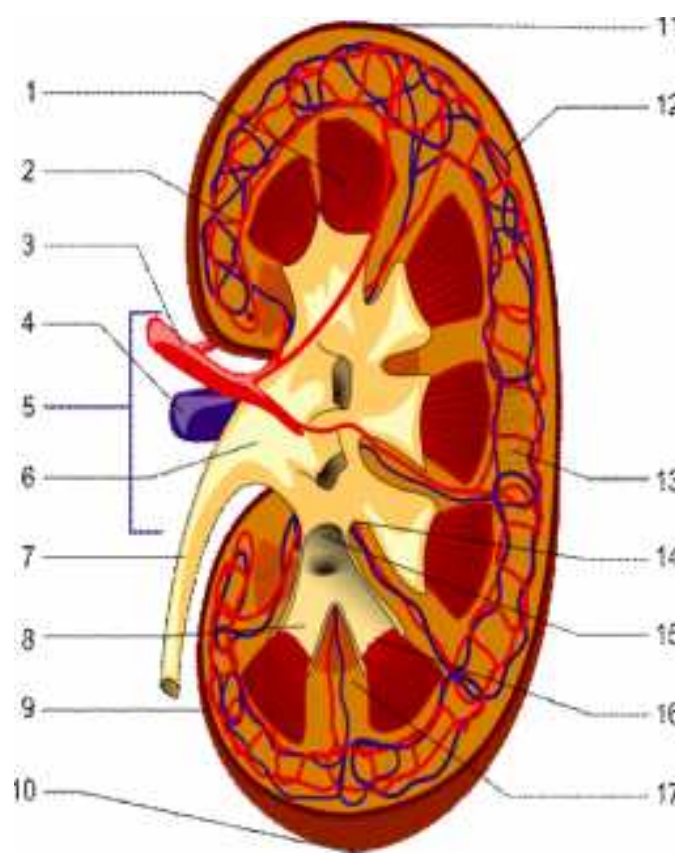

Slika 1. Građa bubrega
1. Malpigijeva piramida,

2. interlobularne arterije,

3. bubrežna arterija,

4. bubrežna vena,

5. hilus,

6. bubrežna karlica,

7. mokraćovod,

8. mala bubrežna čašica,

9. fibrozna kapsula,

10. donji pol,

11. gornji pol,

12. interlobularna vena,

13. nefron,

14. bubrežna duplja,

15. velika bubrežna čašica,

16. papile,

17. Bertinijeva kolumna 
Sa svih strana ga okružuju tri omotača: bubrežna fascija koja oblaže i nadbubrežnu žlezdu, masna čaura (capsula adiposa) i fibrozna čaura (capsula fibrosa).

Na poprečnom preseku bubrega mogu da se uoče karakteristične zone: spoljašnja zona ili kora (cortex renis), unutrašnja zona ili srž (medulla renis) i u sredini karlica bubrega preko koje je bubreg povezan sa organizmom, a čine je krvni i limfni sudovi, simpatički nervi i ureter (Slika 1). Korteks je tamnije boje i zrnaste strukture a medula je prugasta i svetlija. U srži bubrega se nalaze renalne, Malpigijeve piramide, čiji su vrhovi orijentisani prema hilusu. Sa baze renalnih piramida u koru se projektuju prugaste strukture ili medularni zraci (Ferajnove piramide). Od jedne piramide izrasta 400-500 medularnih zraka, a one se tretiraju kao deo kore bubrega (zajedno sa pravim kortikalnim parenhimom). Vrhovi piramida (papile) sadrže tzv. rešetkasto polje sa 1020 papilarnih otvora kroz koje se mokraća iz srži izliva u male bubrežne čašice (calyces renales minores) čijim spajanjem nastaju velike bubrežne čašice (calyces renales majores), a one se otvaraju u bubrežnu karlicu i mokraćovod.

Koru bubrega čini parenhim između renalnih piramida i kapsule i deo parenhima koji prodire između piramida (Bertinijeve kolumne). Manje morfološke celine bubrega su: lobus (jedna Malpigijeva piramida sa delom kore iznad njene baze i delovima susednih kolumni) i lobulus (jedan medularni zrak i delovi lavirinta koji ga okružuju).

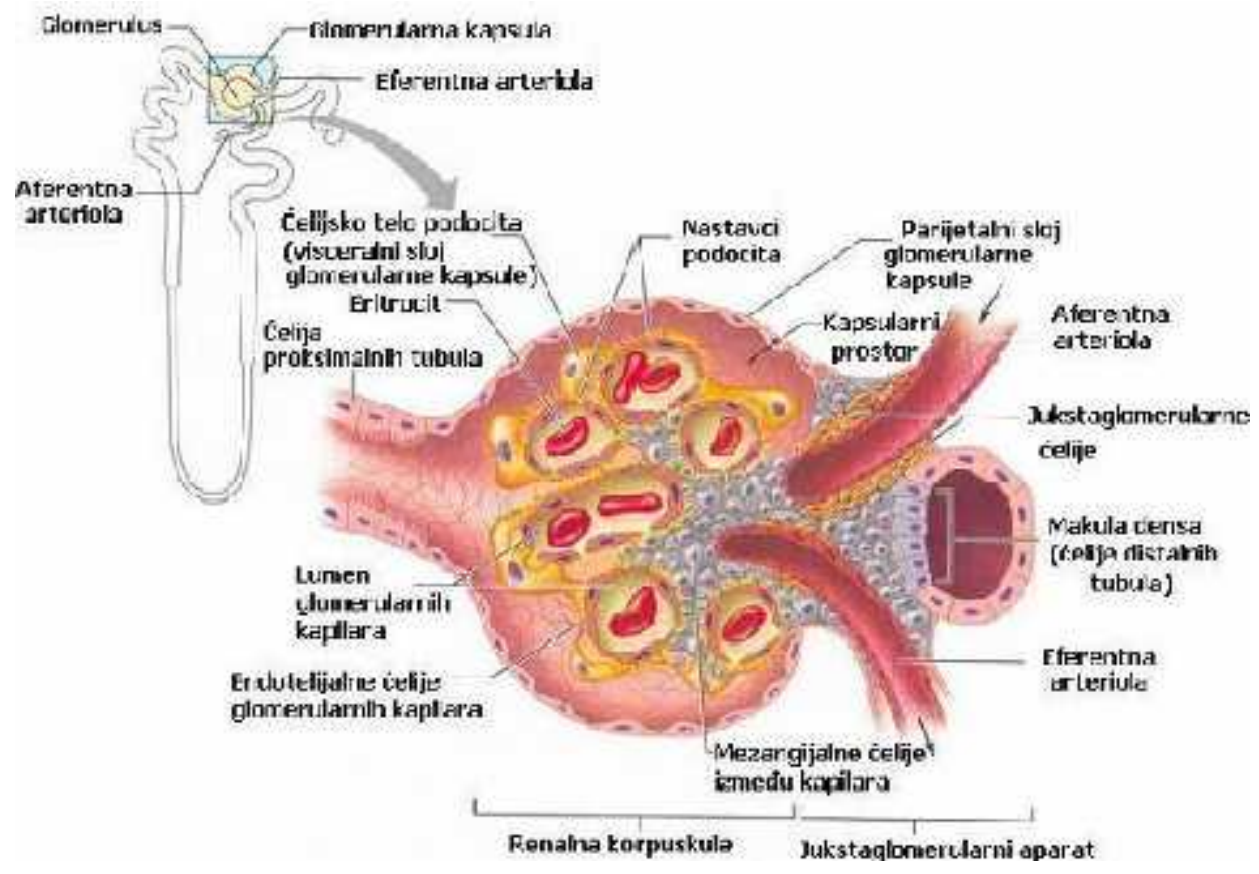

Slika 2. Nefron i glomerul 
Osnovna funkcionalna i morfološka jedinica bubrega je nefron. Svaki bubreg ima oko 1,2 miliona nefrona koji samostalno vrše funkciju tj. stvaraju mokraću. Čovek može da živi sa samo jednom trećinom nefrona. Nefron čine glomerul i tubul (Slika 2).

Glomerul ovijen Bowmanovom kapsulom je početni deo nefrona loptastog izgleda dijametra oko $200 \mu \mathrm{m}$. Glomerul je splet gusto izuvijanih kapilara koji povezuju dovodnu sa odvodnom arteriolom.

Glomerulsku filtracionu membranu gradi fenestrirani zid kapilara, višestruko propustljiviji od somatskih kapilara jer nema dijafragmu i bazalna membrana (Slika 3). Fenestre kapilara propuštaju sve komponente plazme, sem ćelija krvi. Filtraciona membrana je prepreka po veličini i naelektrisanju. Ova porozna membrana ima pore dijametra 7-10 nm, kroz nju se iz plazme, pored vode, filtriraju i svi molekuli sa dijametrom manjim od $10 \mathrm{~nm}$, odnosno molekulskom težinom manjom od 70000 Daltona (molekulska težina albumina je 69000 Daltona i relativno mala količina prelazi dnevno iz kapilara u lumen tubula). Ova membrana dozvoljava prolaz samo najmanjim proteinima i drugim manjim materijama.

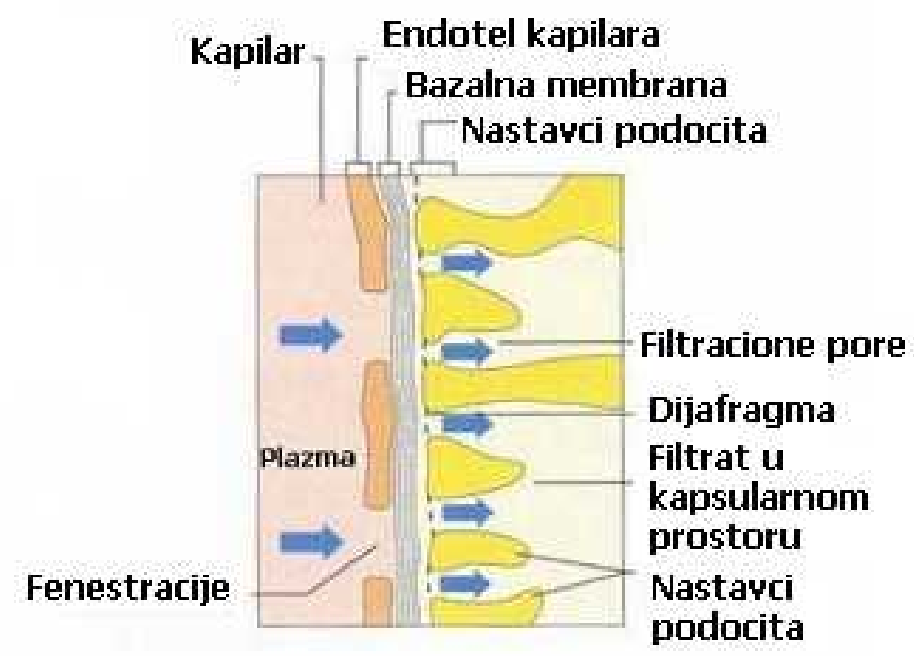

Slika 3. Filtracione membrane

Membrana doprinosi električnoj selektivnosti procesa filtracije, jer je većina proteina membrane negativno naelektrisana. Kako je i većina proteina plazme negativno naelektrisana membrana ih odbija, a ovaj vid selektivnosti blokira prolazak proteina, odnosno pozitivno naelektisane čestice lakše se filtriraju (1). Pri oštećenju glomerulske 
membrane $\mathrm{u}$ urin prelaze i materije sa većom molekulskom težinom kao i uobličeni elementi krvi.

Bowmanova kapsula predstavlja vezu glomerula sa tubulima. Izgrađena je od dva lista, spoljašnjeg, parijetalnog koji ograničava bubrežni korpuskul i odvaja ga od okolnog parenhima i unutrašnjeg visceralnog lista. Između ova dva lista je interkapsularni prostor u koji se filtrira primarna mokraća kao ultrafiltrat krvi.

Bubrežni tubul je nastavak urinarnog pola bubrežnog telašca, proteže se do sabirnog tubula i sastoji se iz proksimalnog izuvijanog tubula, Henleove petlje i distalnog izuvijanog tubula. U tubul se za 24 sata uliva oko 180 litara primarne mokraće. Procesima reapsorpcije i sekrecije u tubulima se u organizam vraća $99 \%$ ultrafiltrata i obrazuje konačna mokraća u količini oko 2 litra dnevno (2-5).

Koncentracija materija u krvi koje se iz organizma izlučuju urinom (urea, kreatinin) direktno zavisi od jačine glomerularne filtracije. U slučajevima kada je zbog ekstrarenalnih (npr. pad arterijskog krvnog pritiska a time i filtracionog pritiska) ili renalnih (npr. smanjenje broja glomerula usled bolesti bubrega) uzroka smanjena glomerulska filtracija dolazi i do nakupljanja tih materija u organizmu.

U održavanju homeostaze kod čoveka bubrezi imaju centralno mesto i ekskretornu, endokrinu i regulatornu funkciju. Preko bubrega se iz organizma ekskretuje većina krajnjih proizvoda metabolizma i višak hranom unetih neorganskih supstanci: neproteinska jedinjenja (kreatinin, urea i mokraćna kiselina), brojne organske kiseline (aminokiseline), neorganske supstance natrijum, kalijum, hlorid, kalcijum, magnezijum, bikarbonat. Glomerulska filtracija i tubulska sekrecija održavaju konstantan optimalan sastav krvi i drugih telesnih tečnosti.

Bubreg je izuzetno značajan i kao endokrini organ jer on stvara renin, eritropoetin, prostaglandine i tromboksane. U njemu se sekundarno aktiviraju hormoni koji se primarno stvaraju u drugim organima. Usled oštećenja funkcije bubrega može da dođe i do poremećaja njegove endokrine uloge. $U$ insuficijenciji bubrega može da se poremeti stvaranje eritrocita $i$ razvije anemija a usled poremećaja stvaranja renina i prostaglandina remeti se regulacija krvnog pritiska. Sekundarno, bubrezi su mesto degradacije insulina, glukagona i aldosterona. U bubrezima se odigrava i hidroksilacija 25-hidroksi holekalciferola pri čemu nastaje 1,25-dihidroksi holekalciferol, najaktivniji oblik vitamina D. Progresivno, hronično renalno oštećenje uvek prati poremećaj strukture kostiju usled izmenjenog metabolizma vitamina D i sekundarno povišenih nivoa paratireoidnog hormona (6). 


\subsubsection{Značaj ranog otkrivanja oboljenja bubrega}

Zbog značaja koji bubreg ima u organizmu važno je rano prepoznati poremećaj njegove funkcije. Do oštećenja bubrega i do poremećaja funkcije mogu da dovedu različiti uzroci kao što su infekcije, opstrukcije, malignitet, inflamacija, prekomerna i dugotrajna upotreba nekih lekova, smanjeni protok krvi kroz bubreg, neke sistemske bolesti, trauma. Procesi koji dovode do oštećenja bubrežne funkcije mogu biti akutne i hronične prirode.

Akutna bubrežna slabost nastaje naglo i razvija se brzo u toku nekoliko dana. Mogu je usloviti stanja koja remete cirkulaciju (šok, infekcije, trovanja), direktna oštećenja parenhima bubrega i opstrukcije urinarnog trakta. Za razliku od akutnog oštećenja, hronična bubrežna slabost se razvija sporo, postepeno, tokom dužeg vremenskog perioda i rana faza oštećenja prolazi najčešće nezapaženo. Hronična slabost bubrega je najčešće posledica hipertenzije, dijabetesa i gojaznosti i postala je glavni problem javnog zdravlja u zapadnom svetu. Po podacima National Institute of Diabetes and Digestive and Kidney Diseases u SAD više od $10 \%$ stanovnika ili više od 20 miliona ljudi starijih od 20 godina ima hroničnu bolest bubrega. Češće oboljevaju žene od muškaraca, $35 \%$ obolelih od hronične bolesti bubrega su dijabetičari, dok više od $20 \%$ obolelih ima hipertenziju (7-11). Nacionalne organizacije zbog rasprostranjenosti i ozbiljnosti hronične bubrežne bolesti izdaju preporuke za praćenje rizičnih grupa da bi što ranije otkrili i planirli startegiju lečenja i praćenja bolesti i edukovali stanovništvo i medicinske profesionalace $(12,13)$.

Faktore rizika za bolesti bubrega predstavljaju i način života, pušenje, dugotrajna upotreba nesteroidnih antireumatika, srčane bolesti, visok holesteroal, ateroskleroza, pozitivna porodična istorija i etnička pripadnost a uključuju i životnu dob. Posle 40 godine života jačina glomerulske filtracije, JGF se smanjuje približno $1 \mathrm{ml} / \mathrm{min} / 1,73 \mathrm{~m}^{2}$ po godini, a brzina smanjenja JGF se povećava posle 65 godine. Starenje je udruženo sa razvojem fibroze tubulointersticijuma, smanjenjem dužine proksimalnih tubula $\mathrm{i}$ gubitkom mase tubula. Povećanje frakcije filtracije sa starenjem je verovatno adaptacija na strukturne promene u bubregu koji pomaže da se očuva funkcija bubrega (14). 


\subsection{JAČINA GLOMERULSKE FILTRACIJE}

Izuzetno je značajno da se određenim dijagnostičkim testovima prati stanje i funkcija bubrega jer blagovremeno otkrivanje i adekvatan tretman mogu znatno da uspore progresiju bubrežne slabosti i da u znatnoj meri očuvaju funkciju bubrega. Kako je bubrežna funkcija izuzetno složena, jasno je da je vrlo teško pronaći idealan i jednostavan način da se proceni i obuhvati najveći broj promena koji se dešavaju tokom razvoja patološkog procesa. Bez obzira što jačina glomerulske filtracije u prvom redu procenjuje proces filtracije u glomerulu, JGF se nameće kao parametar preko koga se može pratiti najveći broj promena u funkciji bubrega. Nefroni ne mogu da se regenerišu tako da svaka povreda, oboljenje ili starenje smanjuju broj nefrona, a samim tim i bubrežnu funkciju. Jačina glomerulske filtracije (JGF) je direktno proporcionalna ukupnom filtracionom pritisku (UFP) odgovornom za formiranje filtrata. Ukupan filtracioni pritisak je rezultat dejstva glomerulskog hidrostatskog pritiska, koloidnoosmotskog pritiska krvi u glomerulima i hidrostatičkog pritiska u kapsuli i iznosi oko 10 mm Hg. Svaka promena ma kog od pritisaka koji deluju na filtracionu membranu rezultuje u promeni UFP i ujedno menja i JGF (15).

Jačinu glomerulske filtracije pojedinačnog nefrona definiše proizvod filtracione površine i jačine kretanja tečnosti kroz zid kapilara glomerula. Smanjenje broja funkcionalnih kapilara glomerula (smanjenje dodirne površine za filtraciju) i povećanje debljine membrane kapilara glomerula i redukcija njene provodljivosti smanjuju jačinu glomerulske filtracije.

Prema National Kidney Foundation Kidney Disease Outcomes Quality Initiative (K/DOQI) i National Kidney Disease Education Program (NKDEP) jačina glomerulske filtracije najbolje procenjuje funkciju i stepen oštećenja bubrega. Ove američke organizacije rane faze hronične bubrežne bolesti definišu kao JGF manju od 60 $\mathrm{ml} / \mathrm{min} / 1,73 \mathrm{~m}^{2}$ ili prisustvom oštećenja bubrega tri ili više meseci bez obzira na uzrok nastanka (13). Američka fondacija za bubreg 5 stadijuma hronične bolesti bubrega klasifikuje prema vrednostima JGF, jer do promene JGF dolazi pre pojave vidljivih znakova poremećene funkcije bubrega (11).

U nekim fiziološkim stanjima, kao što je trudnoća usled hormonskih i hemodinamskih promena povećava se protok krvi kroz bubreg za 50-65 \% a JGF za 40-65 \%. Studije koje koriste gravidne pacove kao model imaju veliki značaj za razumevanje mehanizma promena renalne cirkulacije tokom trudnoće $(16,17)$. 
U trudnoći ovarijalni hormon, relaksin, povećava aktivnost vaskularne želatinaze preko azot oksida i dovodi do renalne vazodilatacije. Pored vazodilatacije dolazi i do hiperfiltracije i smanjenja miogene reaktivnosti malih renalnih arterija. Hiperfiltracija je jedan od uzroka povećanja protoka kroz bubreg i povećane JGF. Povećana ekskrecija proteina je posledica smanjene reapsorpcije u proksimalnim tubulima i verovatno je pod uticajem elektrostatskog naelektrisanja glomerularnog filtra dok je porast tubulske sekrecije Tamm-Horsfall proteina tokom trudnoće nejasan (18). Pojava proteinurije može da bude rani subklinički znak poremećene bubrežne funkcije u trudnoći, i može da dovede do niza komplikacija kao što su trudnoćom izazvana hipertenzija, preeklampsija i eklampsija. Da bi se izbegle ili smanjile komplikacija tokom trudnoće veliki izazov za kliničare i istraživače je da otkriju promene na bubrezima rano, pre pojave bilo proteinurije, bilo trudnoćom izazvana hipertenzija kao blažih oblika preeklampsije ili preeklampsije (19).

Proteinurija označava pojavu proteina u urinu. Kod odraslih, zdravih ljudi količina proteina u urinu je vrlo mala i kreće se do $150 \mathrm{mg}$ dnevno. Proteini koje se nalaze $\mathrm{u}$ normalnom urinu potiču iz plazme i iz tubula. U fiziološkim uslovima se iz plazme kroz membranu glomerula filtriraju proteini male molekulske mase i izvesna količina albumina (2 do $3 \mathrm{~g} / 24 \mathrm{~h}$ ), dok proteini veće molekulske mase praktično ne dospevaju u glomerulski filtrat. Filtrirani proteini se u tubulima bubrega skoro potpuno reapsorbuju procesom pinocitoze i samo mali deo se izluči mokraćom (40 do $50 \mathrm{mg}$ ). Proteini se reapsorbuju uglavnom u proksimalnim tubulima, čiji kapacitet za reapsorpciju proteina je relativno mali i verovatno ne premašuje količinu koja se normalno filtrira. Reapsorbovani proteini se katabolišu u ćelijama tubula, a oslobođene aminokiseline i peptidi se vraćaju u cirkulaciju limfom.

Kod endemske nefropatije je važno blagovremeno postaviti dijagnozu. Zbog neprepoznatljivih znakova bolesti u ranoj fazi, pretpostavlja se da početni stadijum dugo traje, pa je pažnja usmerena na otkrivanje ranih subkliničkih manifestacija bolesti. U ranom stadijumu, dok nije poremećena bubrežna funkcija, klinička slika je veoma oskudna. Bolesnici povremeno osećaju tupe bolove u predelu bubrega, glavobolju, vrtoglavice, dispeptičke tegobe, gubitak telesne težine i malaksalost dok su otoci po pravilu odsutni. Renalna intersticijalna fibroza je glavna morfoloska karakteristika endemske nefropatije i istovremeno najvažniji uzrok hronične bubrežne insuficijencije. Renalna intersticijalna fibroza je abnormalan proces taloženja velike količine vanćelijskog matriksa koji ima kompleksnu strukturu sačinjenu od različitih elemenata 
vezivnog tkiva kao sto je kolagen tip I, laminin, fibronektin, elastin, proteoglikani itd. Struktura tubulointersticijuma zdravih bubrega bez fibroze je zasnovana na balansu između različitih delova renalnih komponenti: intersticijalnih ćelija, ekstracelularnog matriksa, tubularnih i endotelnih celija. Renalna intersticijalna fibroza se razvija samo kada se javi disbalans izmedju ovih komponenti, a pretpostavlja se da bi svaka od njih mogla da bude okidač u razvoju fibroze.

Endemsku nefropatiju karakterišu brojni funkcionalni poremećaji. U ranom stadijumu oni ukazuju na promene tubulskih funkcija, a sa napredovanjem patološkog procesa, se smanjuje glomerulska filtracija i razvija globalna bubrežna insuficijencija. U početku bolesti JGF i sposobnost koncentrovanja urina su normalni a smanjuje se kako bolest napreduje. U inicijalnoj fazi bolesti, kreatinin i urea pokazuju normalne vrednosti u serumu. Kasnije, sa napredovanjem bolesti, sa razvojem bubrežne insuficijencije vrednosti rastu.

\subsection{METODE ZA MERENJE JAČINE GLOMERULSKE FILTRACIJE}

Jačinu glomerulske filtracije nije moguće određivati direktno tako da se određivanje JGF zasniva na merenju koncentracije različitih endogenih i egzogenih supstanci u krvi i u urinu. Supstance koje se koriste za merenje JGF moraju da poseduju određena svojstva tj. treba da budu fiziološki inertna, da ne budu vezana za protein i da se slobodno filtriraju kao i da se ne reapsorbuju, sekretuju, sintetišu ili metabolišu u renalnim tubulima. Shodno ovome količina supstance koja se filtrira u glomerulu mora da bude ista kao i količina koja se ekskretuje u urin. Ovakav proces se može definisati sledećom jednačinom:

$\mathbf{J G F} \times \mathbf{P x}=\mathbf{U x} \times \mathbf{V}$

gde je Px i Ux koncentracija supstance u plazmi i urinu a V protok urina, pa se JGF izračunati iz jednačine

$\mathbf{J G F}=\mathbf{U x} \times \mathbf{V} / \mathbf{P x}$

Apsolutna količina filtrata koji se stvori u normalnim uslovima promenljiva je i zavisi od veličine tela tako da se JGF izražava prema normalnoj površini tela.

U kliničkoj praksi se različite supstance i metode koriste za određivanje JGF. Najpreciznija i najpouzdanija metoda za evaluaciju bubrežne funkcije je procena JGF 
merenjem klirensa egzogenih supstanci kao što su Inulin, ${ }^{51} \mathrm{Cr}$ Etilenediamintetrasirćetna kiselina $\left({ }^{51} \mathrm{Cr}\right.$-EDTA $),{ }^{99 \mathrm{~m}} \mathrm{Tc}$-dietilentriaminpentasirćertna kiselina ili ${ }^{125} \mathrm{~J}$-iotalamat koji važe za idealne markere JGF. U rutinskim laboratorijama za procenu bubrežne funkcije se određue koncentracija kreatinina u serumu i u 24 časovnom urinu kao klirens kreatinina. U poslednje vreme za procenu JGF mesto pronalaze proteini plazme male molekulske mase kao što su beta trace protein, $\beta_{2}$ mikroglobulin i cistatin C. I različite prediktivne jednačina koje uključuju koncentraciju kreatinina, tau proteina ili cistatina $\mathrm{C}$ u serumu se koriste za procenu JGF.

\subsubsection{Metode zasnovane na klirensu neizotopa i radionukleida}

Inulin je neizotpska supstanca, polimer fruktoze izolovan iz Jerusalimske artičoke sa molekulskom masom koja je približno $5 \mathrm{kDa}$. Smatra se zlatnim standardom za merenje JGF. Određivanje JGF pomoću klirensa inulina zahteva kontinuiranu intravensku infuziju tokom koje se uzorkuju plazma i urin u vremenski definisanim intervalima. Inulin se u uzorcima određuje spektroskopski uz upotrebu rezorcinola. Ovaj metod je skup za izvođenje i zahteva posebnu opremu što mu ograničava primenu u rutinskoj kliničkoj praksi (20).

Pored klirensa inulina primenjuje se i klirens supstanci obeleženih radioaktivnim elementima. Zbog dostupnosti, dobre korelacije sa klirensom inulina i jednostavnog merenje u plazmi i urinu ${ }^{125}$ J-iotalamat je preporučljiv za precizno i pouzdano određivanje JGF i pored činjenice da je 5-25\% vezano za proteine plazme a $20 \%$ njegove količine u urinu potiče od sekrecije. Primenu ${ }^{125} \mathrm{~J}$-iothalamata u kliničkoj praksi ograničavaju visoka cena, zahtevna oprema za prikupljanje i određivanje i bezbednost bolesnika i osoblja koje ga aplikuje i rukuje. Da bi se izbeglo izlaganje bolesnika i medicinskog osoblja štetnom radioaktivnom dejstvu razvijene su metode za kapilarnu elektroforezu i HPLC na bazi iotalamata koji nije obeležen radioaktivnom komponentom, a zadovoljavajuće korelišu sa materijalom obeleženim jodom ${ }^{125}$ (21-23). Nisu nađene značajne razlike između izotopskih i neizotopskih metoda $u$ određivanju JGF, odnosno obe metode su uporedive. Izotopske metode su reproducibilne i u korelaciji sa klirensom inulina, kao zlatnim standardom za određivanje JGF (24).

Takođe se JGF može proceniti radionuklidima kao što su ${ }^{99 m} \mathrm{Tc}-\mathrm{DTPA},{ }^{99 \mathrm{~m}} \mathrm{Tc}-$ mercaptoacetyltriglycine (MAG3) ili ${ }^{123} \mathrm{~J}$-iodohipurate, koji se inače koriste u 
bubrežnim imidžing tehnikama. U odnosu na druge metode sa primenom radiofarmaka ${ }^{99 m}$ Tc-DTPA je relativno jeftin, jednostavan za pripremu, dobro korelira sa klirensom inulina a bolesnik je izložen niskoj dozi radijacije. Zbog toga je klirens ${ }^{99 m}$ Tc-DTPA najviše primenljivana metoda za procenu JGF u rutinskim laboratorijama (25-29).

\subsubsection{Metode zasnovane na serumskom kreatininu}

Kao skrining test za procenu stanja bubrega mnogi lekari rado koriste kreatinin i njegov renalni klirens. Kreatinin ima molekulsku masu $113 \mathrm{Da}$, produkt je hidrolize kreatina i fosfokreatina koja se odvija u mišićima pa je proporcionalan mišićnoj masi. Filtrira se u glomerulama a sekretuju ga ćelije proksimalnih tubula. Malo varira iz dana u dan. Koncentracija u serumu je nelinearno recipročna JGF pa se smatra da odražava JGF (30).

Određivanje JGF metodom sa inulinom i drugim osetljivim metodama je pokazalo da je kreatinin nedovoljno osetljiv za procenu JGF kod blago i umereno oštećene funkcije bubrega jer njegova koncentarcija u serumu ostaje nepromenjena. Kada se stanje bubrega procenjuje na osnovu koncentracije kreatinina u serumu mora da se ima u vidu da razlike u mišićnoj masi menjaju nivo nastajanja kreatinina što je naročito značajno kod procene JGF kod dece (31). Kreatininemija zavisi od pola, starosne dobi i rase pa je i zato nepouzdana za procenu JGF (32). Koncentracija kreatinina menja se zbog promena ishrane kao što su mali ili prevelik unos proteina, malnutricija, kao i pri amputaciji ekstremiteta, dužem ležanju u bolnici, kod ciroze jetre, inflamacije i drugih hroničnih bolesti (npr. maligniteti, teške kardiovaskularne bolesti). Koncentraciju kreatinina povećavaju lekovi koji inhibiraju njegovu sekreciju u tubulima (cimetidin, trimetoprim) ili inhibiraju njegovu gastrointestinalnu degradaciju (antibiotici širokog spektra) a da pri tom JGF može da ostane nepromenjena (33). Kada je JGF niska može da se poveća intestinalna eliminacija kreatinina i pogrešno proceni JGF.

Fiziološko povećanje JGF tokom trudnoće snižava koncentraciju kreatinina u serumu, tako da se kreatinin kreće od $35 \mu \mathrm{mol} / 1$ do $72 \mu \mathrm{mol} / 1$ a kreatinemija od 88 $\mu \mathrm{mol} / 1$ koja je normalna za negravidne žene kod trudnica može predstavljati znak smanjenja renalne funkcije.

Da bi se poboljšale karakteristike markera kao što je kreatinin za procenu JGF razvijene su posebne prediktivne jednačine da bi prevazišle nedostatke markera $\mathrm{i}$ da budu približno jednako pouzdane za sva patološka stanja. Ove jednačine su nastale 
primenom regresionih tehnika na povezanost između serumskih nivoa filtracionih markera i izmerene GFR u proučavanoj populaciji. U njima se koristi nivo kreatinina i cistatina C u serumu. Razvijene su za svaki parametar pojedinačno, uzimaju u obzir telesnu površinu kao zamenu za mišićnu masu, pol, rasu i starost. NKDEP preporučuje da laboratorije izdaju paralelno sa nivoom kreatinina i preračunatu JGF, eJGF.

Prediktivne jednačine za preračunavanje GFR iz vrednosti kreatinina u serumu su razvijene za decu i uglavnom se koriste Schwartzova i Counahan-Barratova formula.

Schwartzova jednačina:

$\operatorname{GFR}(\mathrm{mL} / \mathrm{min})=0,55 \times[\operatorname{visina}(\mathrm{cm})] /[\mathrm{SCr}(\mathrm{mmol} / \mathrm{l}) / 88,4]$

Counahan-Barratova jednačina:

$\operatorname{GFR}(\mathrm{mL} / \mathrm{min})=0,43 \times[\operatorname{visina}(\mathrm{cm})] /[\mathrm{SCr}(\mathrm{mmol} / \mathrm{l}) / 88,4]$

$\mathrm{SCr}$ - koncentracija kreatinina u serumu

Kod odraslih se koristi jednačina koju su predložili Cockcroft $i$ Gault, kao i jednačina iz studije MDRD (Modification of Diet in Renal Disease). Cockcroft-Gaultova formula se široko koristi u farmokokinetičkim studijama kao vodiči za doziranje lekova koji se eliminišu putem bubrega. Razvijena je 1973. godine iz podataka dobijenih od 249 muškaraca sa klirensom kreatinina u rasponu od 30 do $130 \mathrm{ml} / \mathrm{min}$. Ova jednačina predviđa klirens kreatinina $(\mathrm{ml} / \mathrm{min})$ iz koncentracije kreatinina $\mathrm{u}$ serumu, telesne težine i godina starosti.

Najčešće su u upotrebi za preračunavanje JGF iz kreatinina kod odraslih sledeće jednačine:

Cockcroft-Gaultova jednačina:

$\mathrm{CCr}(\mathrm{ml} / \mathrm{min})=[(140-$ godine $) \times$ telesna težina $(\mathrm{kg})] /[0,81 \mathrm{~s} 4 \times \mathrm{SCr}] \times[0,85$ ako je žena]

\section{MDRD jednačina:}

$\mathrm{JGF}=32,788 \times\left[\mathrm{SCr}^{]-1,154} \times[\text { godine }]^{-0,203} \times[0,742\right.$ ako je žena $] \times[1,210$ ako je crnac $]$ »Korigovana« MDRD jednačina:

$\mathrm{JGF}=30,849 \times[\text { standardizovan } \mathrm{SCr}]^{-1,154} \times[\text { godine }]^{-0,203} \times[0,742$ ako je žena $]$

$\mathrm{CCr}$ - klirens kreatinina; SCr - kreatinin u serumu u mmol/l; JGF izražena u $\mathrm{ml} / \mathrm{min} / 1,73 \mathrm{~m}^{2}$. 
Različite radne grupe i dalje rade na usavršavanju jednačina da bi se što pouzdanije i na najmanje komplikovan način procenila funkcija bubrega odnosno JGF.

Formule za procenu JGF koje se zasnivaju na nivou kreatinina u serumu i koje su razvijene za negravidnu populaciju nepouzdane su kada se primene za procenu JGF kod trudnica jer smanjenje kreatinina kod trudnica nije samo posledica trudnoćom izazvanog povećanja JGF već i hemodilucije zbog povećanog volumena plazme. U Modification of Diet in Renal Disease (MDRD) formuli za procenu JGF koristi se kombinacija serumskih markera i kliničkih parametara za utvrđivanje stanja bubrega kod bolesnika sa HBB. Ova formula nije proučavana na populaciji trudnica i vodiči koji definišu primenu MDRD isključuju njenu primenu kod gravidnih žena. Ni formule koje se baziraju na telesnoj težini kao Cockroft-Gault, nisu pouzdane jer povećanje telesne težine u trudnoći nije posledica povećanja mišićne mase pa samim tim nema povećanja produkcije kreatinina. Neki autori smatraju da u nedostatku boljih, klirens kreatinina ostaje najpouzdanije kliničko oruđe za procenu stanja bubrega u trudnoći (34)

U kliničkim studijama MDRD formula je prvi put 2007. godine testirana za trudnice (35-37). Poredili su MDRD formulu (bazirana na godinama, serumskom kreatininu i polu) sa klirensom inulina kod tri gupe žena: zdravih trudnica, trudnica sa preeklampsijom i trudnica koje su pre trudnoće već bolovale od HBB. Dok je kod zdravih trudnica 24-h klirens kreatinina bio približan JGF dobijenoj klirensom inulina, dotle je JGF procenjena MDRD jednačinom bila precenjena za $>40 \mathrm{ml} / \mathrm{min}$, što je stepen biasa veći nego kod negravidnih donora bubrega sa normalnom bubrežnom funkcijom (29 ml/min) (38). Kod trudnica sa preeklampsijom i HBB MDRD formulom dobijena je precenjena vrednost JGF za 23,3 i 27,3 ml/min što je manje nego u prvoj grupi. Kod sve tri grupe MDRD formulom je dobijena JGF $>60 \mathrm{ml} / \mathrm{min}$ što je veći bias u odnosu na negravidnu populaciju. Iz ovih razloga je primena ove formule za procenu stanja bubrega tokom trudnoće nesigurna.

Posebnu vrstu problema pri upotrebi serumskog kreatinina za procenu JGF predstavlja metodološki pristup određivanju koncentracije kreatinina u serumu. Laboratorije za određivanje koncentracije kreatinina u serumu najčešće koriste Jaffeovu metodu koja se zasniva na kolorimetrijskom merenju kompleksa koji kretinin gradi sa alkalnim pikratom. Pouzdanost ove metode ograničava prisustvo različitih interferirajućih supstanci kao što su acetoacetat, askorbinska kiselina, fruktoza, piruvat, cefalosporini i neke druge endogene nekreatininske hromogene supstance koje dovode do smanjenja analitičke specifičnosti ove metode. 
Enzimska ili delimično enzimska određivanja, koja su razvijena da se poveća osetljivost Jaffeove metoda, manje su podložne intreferencijama nego Jaffeova metoda ali ipak neke supstance kao što su bilirubin, metamizol, 5-fluorocitozin, dopamin, dobutamin, kao i unakrsno vezani hemoglobin sa monoklonalnim IgM interferiraju sa enzimskim metodama za kreatinin. Uticaj ovih hromegena se može umanjiti adekvatnim odabirom automatskih analizatora što ukupno povećava specifičnost metode enzimskog određivanja.

Prisustvo interferirajućih supstanci kao što su glukoza i acetoacetat predstavlja naročit problem za monitoring dijabetičara sobzirom da se oštećenje bubrega često može pojaviti i pre manifestacije šećerne bolesti te je neophodna pravovremena i tačna procena stanja bubrega.

Tečni hromatografijski (HPLC) postupak i izotop-dilucione maseno spektrometrijske (IDMS) metode su razvijene za procenu stvarne koncentracije kreatinina, jer imaju veliku osetljivost i analitičku specifičnost (39). Kombinacija gasne hromatografije (GC) i IDMS se smatra metodom izbora za utvrđivanje tačne koncentracije kreatinina, zbog visoke specifičnosti i standardne devijacije manje od 0,3 \%. Na postojećim analizatorima aplikacije kinetičke Jaffeove metode u nerazblaženom serumu ili plazmi daju pozitivno odstupanje kada se uporede sa IDMS ili HPLC metodom, naročito pri koncentracijama unutar referentnog intervala (40). Uočena je i razlika $\mathrm{u}$ dobijenim vrednostima kreatinina $\mathrm{u}$ istom uzorku iz različitih laboratorija. Program IMEP-7 (International Measurement Evaluation Program) je sproveden u više od 800 laboratorija iz 35 zemalja i pokazao je pozitivno odstupanje između $10 \%$ i $15 \%$ u pool uzorku koncentracije kreatinina od $75 \mu \mathrm{mol} / 1$ (41). Sistematske razlike u kalibraciji metoda za kreatinin u serumu su u $85 \%$ slučajeva odgovorne za razlike između laboratorija. Do sistemske greške u određivanju kreatinina dolazi usled toga što su laboratorije koristile različite postupke određivanja kao i različite standarde što je uslovljavalo i razliku u referentnim nivoima kreatinina.

Uočivši ovaj problem National Kidney Disease Education Program (NKDEP) formirao je radnu grupu za razvijanje standarda za kalibraciju kreatinina za njegovo određivanje u serumu što za poboljšanje tačnosti određivanja kreatinina zahteva od proizvođača da standardni kalibracioni i kontrolni materijal bude sledljiv sa referentnim mernim postupcima i referentnim materijalima. Kao primarni referenti materijal koristi se kristalni kreatinin, koji je označen kao SRM (Standard Reference Material) 914a. Kalibracioni rastvori SRM 914a pripremaju se gravimetrijskim rastvaranjem kristalnog 
kreatinina $\mathrm{u}$ vodenom puferu i primarno su namenjeni za upotrebu $\mathrm{u}$ referentnim mernim postupcima (GC-IDMS, LC-IDMS) i nisu pogodni za direktno određivanje na rutinskim kliničkim analizatorima. NKDEP i NIST (National Institute of Standards and Technology) su pripremili humani serumski referentni materijal za kreatinin označen kao SRM 967 (39). Postizanje merne sledljivosti je neophodno da bi mogli da se upoređuju rezultati određivanja kreatinina pomoću različitih metoda ili u različitim laboratorijama za šta je nužna saradnja na međunarodnom nivou i proizvođača testova za određivanje i kliničkih laboratorija, profesionalnih organizacija, državnih agencija i organizatora kontrole kvaliteta. Tek tako usaglašene metode određivanja mogu dati pouzdane rezultate koji predstavljavaju stvarnu vrednost kreatinina u serumu da se sa velikom pouzdanošću proceni JGF i funkcionalna sposobnost bubrega.

\subsubsection{Klirens kreatinina}

Uobičajeno je da se u laboratorijama meri klirens kreatinina tako što se urin sakuplja 24 sata i tokom tog perioda se uzima krv za utvrđivanje koncentracije kreatinina $\mathrm{u}$ serumu. Pošto se kreatinin sekretuje u tubulima, izračunat klirens kreatinina kod zdravih osoba za oko 10-40 \% precenjuje vrednost JGF. Ovaj problem naročito dolazi do izražaja kad određujemo JGF bolesnicima koji imaju hroničnu bubrežnu bolest gde je JGF inače smanjena zbog sekrecije kreatinina u crevima gde se pod dejstvom bakterija razgrađuje. Aplikacija Jaffeove metode je nepogodna za određivanje klirensa kreatinina i zbog toga što se u urinu ne nalaze pseudo-kreatinski hromogeni pa je klirens kreatinina sistematski snižen. Međutim, kako se kreatinin kao što je rečeno, sekretuje u tubulima uspostavlja se ravnotežu između stvarnog i izmerenog kreatinina pa se izmeren klirens kreatinina pribižuje nivou JGF.

Poseban nedostatak metode su problemi oko nekompletnog sakupljanja urina. Sakupljanje uzoraka urina tokom određenih vremenskih perioda je komplikovan postupak za bolesnike naročito ako ih medicinsko osoblje nije dobro edukovalo i ako ne shvataju koliko je važno tačno i precizno prikupljanje svake porcije urina $u$ vremenskom intervalu. Neophodno je pre svega da se obezbedi adekvatan protok urina uz komletno pražnjenje bešike (42). Nekompletno prikupljanje urina može dovesti do velike greške u određivanju klirensa kreatinina. Pokušaji da se uvedu u rutinsku praksu kraći periodi sakupljanja urina nisu opravdali očekivanja i nisu poboljšali osetljivost procene JGF pomoću klirensa kreatinina (43). Studija Smitha i saradnika 
(36) je u kohorti od 209 žena sa preeklampsijom posmatrala JGF. Poređen je klirens kreatinina iz 24-satnog urina, Cockroft-Gault formula, i dve verzije MDRD formule. Rezultati studije su pokazali da Cockroft-Gault formula precenjuje GFR približno za $40 \mathrm{ml} / \mathrm{min}$, dok MDRD formule precenjuju GFR za 19,68 $\mathrm{ml} / \mathrm{min}$ za punu MDRD formula i 12,6 ml/min za modifikovanu MDRD. Kao i u drugim studijama, srednja vrednost JGF i u ovoj studiji je bila $60 \mathrm{ml} / \mathrm{min}$ (36). I najnovije studije su pokazale slične rezultate. Ispitivana je pouzdanost klirensa kreatinina, Cockroft-Gault i MDRD formule za procenu JGF uz klirens inulina kao standard kod tudnica. Ispitivanje je obuhvatilo negravidne žene i trudnice u prvom trimestru ( 8 nedelja). Rezultati studije su pokazali da tokom rane trudnoće JGF merena inulinom poraste $32 \%$ u odnosu na nivo pre trudnoće, dok JGF merena indirektnim metodama poraste za $20 \%$. Sagledavši bias i granice pouzdanosti zaključuje se da je za sve tri metode JGF veća u odnosu na vrednosti pre trudnoće. Hiperfiltracija u trudnoći smanjuje pouzdanost Cockroft-Gault i MDRD formula i klirensa kreatinina za procenu JGF pa je nužno istražiti nove markere $(44,45)$.

\subsubsection{Endogeni filtracioni marker - cistatin C}

Za procenu jačine glomerulske filtracije sve češće se primenjuju proteini male molekulske mase kao pouzdaniji u odnosu na kreatinin zbog njegovih ograničenja. Iz više razloga se cistatin $C$ nameće kao pogodan endogeni filtracioni marker JGF. Njegov nivo u krvi nelinearno inverzno korelira sa JGF. Sa opadanjem JGF raste proporcionalno koncentracija cistatina C. Stepen korelacije između cistatina C i smanjenja JGF u opsegu od 80 do $40 \mathrm{ml} / \mathrm{min} / 1,73 \mathrm{~m}^{2}$ je veći u poređenju sa stepenom korelacije između JGF i kreatinina.

Cistatin $\mathrm{C}$ je neglikozilirani osnovni protein plazme, u konstantnom stepenu stvaraju ga ćelije sa jedrom tokom čitavog života a eliminiše se skoro isključivo glomerulskom filtracijom. Član je familije 2 superfamilije cistatin proteina, koji su fiziološki potentni, ne-kovalentni, kompetitivni snažani inhibitori cistein proteinaza sisara iz lizozma koje su evolutivno konzervisane (Tabela 1). U organizmu ima ulogu kao vanćelijski inhibitor cistein proteaza i raznih katepsina. U ranijoj literaturi, pre nego je sekvencioniran, susreće se pod nekoliko različitih imena kao što su $\gamma$-trace, post- $\gamma$ globulin, i gamma-CSF (46-48). Dve godine posle sekvencioniranja identifikovan je 
kao inhibitor cistein proteaza. Cistatin $\mathrm{C}$ deluje regulatorno i na druge proteaze $\mathrm{u}$ vanćelijskom prostoru (49).

Tabela 1. Superfamilija cistatina kod ljudi

\begin{tabular}{|l|l|l|l|}
\cline { 2 - 4 } \multicolumn{1}{c|}{} & Familija 1 & Familija 2 & Familija 3 \\
\hline Distribucija & intracelularno & ekstracelularno & intravaskularno \\
& & cistatin C & $\begin{array}{l}\text { niskomolekularni } \\
\text { kininogen }\end{array}$ \\
& cistatin A & cistatin D & cistatin S \\
& cistatin B & cistatin SN & visokomolekularni \\
& & kininogen \\
\hline
\end{tabular}

Cistatin C je protein molekulske mase od 13,359 kD. Izoelektrična tačka mu je relativno visoka 9,2 i omogućava mu lakšu filtraciju u odnosu na druge proteine male molekulske mase. Sastoji se od 122 aminokiseline (Slika 4).

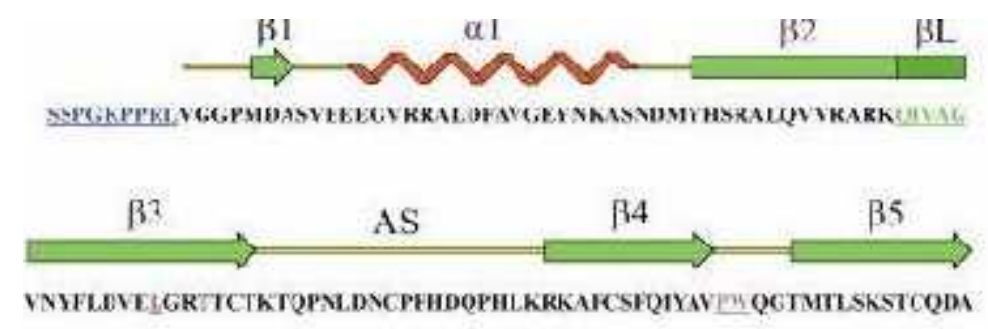

Slika 4. Primarna i sekundarna struktura cistatina $C$

Kao i kod ostalih članova familije 2 cistatina četiri cisteinske rezidue formiraju dve karakteristične disulfidne veze, između rezidua 73 i 83 i rezidua 97 i 117. Sekundarnu strukturu karakteriše dugi $\alpha 1$-heliks koji se rasprostire preko antiparalelne $\beta$-ploče koja se sastoji iz pet lanaca. 
U interakciju sa enzimom uključena su tri regiona (Slika 5). N-terminalni segment i dve petlje oblika ukosnice, L1 i L2 (50).

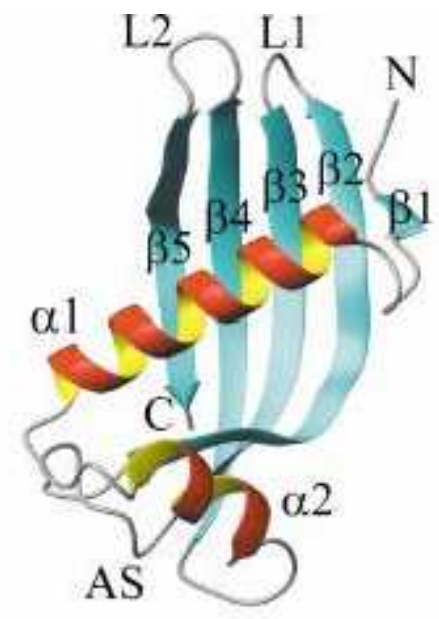

Slika 5. Tercijarna struktura cistatina $\mathrm{C}$

Uporedna analiza sekvence aminokiselina još tri pripadnika ove familije, cistatina S, SN i SA, pokazala je oko $90 \%$ međusobne identičnosti strukture, odnosno $50 \%$ je identična sa cistatinom C. Sintetiše se kao preprotein sa signalnim peptidom što ukazuje na ekstraćelijske funkcije ovog inhibitora. Kodiran je genom na humanom hromozomu 20p11.2. Eksprimira se u bubrezima, jetri, pankreasu, plućima, placenti, a najviši nivo je zabeležen u vesiculae seminalis (51). Obrazac ekspresije koji očito nije tkivnospecifičan u vezi je sa regionom uz 5'-kraj koji ima zajednička svojstva sa „housekeeping“ genima.

Cistatin $\mathrm{C}$ ima brojne biološke funkcije, inhibiše cistein peptidaze (pogotovo katepsin B, H, L i S) i kontroliše ekstraćelijsku proteolizu (52). Učestvuje u modulaciji imunskog sistema, modifikaciji odgovora organizma na oštećenja mozga, kontroliše antibakterijske i antivirusne aktivnosti (53).

Stvaranje cistatina $\mathrm{C}$ nije pod uticajem inflamacije pa on nije protein akutne faze. Aktivan je u obliku monomera a tokom prometa u ćeliji je u obliku dimera i tada potpuno gubi biološku aktivnost (54). Na modelu pacova dokazano je da mu je poluživot 20 minuta. U pojedinim humanim kompartmentima kao što je likvor cistatin C predstavlja više od 90 \% ukupne molarne koncentracije inhibitora cistein proteaza, dok u krvnoj plazmi predstavlja svega nekoliko procenata inhibitornog kapaciteta za cistein protease. Pretpostavlja se da ima protektivnu ulogu u nagomilavanja amiloida- $\beta$ 
u Alchajmerovoj bolesti. Eksperimenti na miševima su pokazali da cistatin $C$ vezuje rastvoreni peptid amiloid- $\beta$ i sprečava da se nagomila u proteinu prekursoru amiloida- $\beta$, što bi bilo značajno u patogenezi i modulaciji koncentracije cistatina $\mathrm{C}$ kao pristup lečenju Alchajmerove bolesti $(55,56)$. Uočena je veza između mutacije cistatin $\mathrm{C}$ gena $\mathrm{i}$ nasledne cerebrovaskularne angiopatije $(57,58)$.

Zbog male molekulske mase cistatin $\mathrm{C}$ se lako filtrira kroz bazalnu membranu glomerula i na taj način skoro se potpuno eliminiše iz cirkulacije posle čega se, ako tubuli nisu značajno oštećeni, više od $99 \%$ reapsorbuje u epitelnim ćelijama proksimalnih tubula gde se u potpunosti kataboliše i ne vraća se u cirkulaciju što znači da njegova koncentarcija u serumu prvenstveno zavisi od jačine glomerulske filtracije pa se zato i smatra dobrim endogenim pokazateljom bubrežne funkcije odnosno JGF. Pokazano je da cistatin C kao biomarker JGF bolje korelira sa klirensima egzogenih filtracionih markera od kreatinina i da je njegova dijagnostička tačnost za detekciju bolesti bubrega bolja u odnosu na kreatinin jer ima veću osetljivost (81 \%) i sličnu specifičnost $(88 \%)$ u poređenju sa kreatininom $(69 \% ; 88 \%)$ pri proceni bubrežne disfunkcije. Koncentracija cistatina $\mathrm{C}$ se povećava pri smanjenju JGF već od 80 $\mathrm{ml} / \mathrm{min} / 1,73 \mathrm{~m}^{2}$, dok se povećanje koncentracije kreatinina javlja pri JGF $<40$ $\mathrm{ml} / \mathrm{min} / 1,73 \mathrm{~m}^{2}$. Zato što se reapsorbuje $\mathrm{i}$ potpuno metaboliše $\mathrm{u}$ tubulima njegova koncentracija u urinu zdravih osoba je vrlo niska.

$\mathrm{U}$ Tabeli 2. su prikazane normalne koncentracije humanog cistatina $\mathrm{C}$ u telesnim tečnostim kod zdravih odraslih osoba.

Tabela 2. Normalna koncentracija humanog cistatina $\mathrm{C}$ u telesnim tečnostim kod zdravih odraslih osoba

\begin{tabular}{|l|c|l|}
\hline telesna tečnost & srednja vrednost & opseg $(\mathbf{m g} / \mathbf{l})$ \\
\hline krv & 0,96 & $0,57-1,79$ \\
\hline likvor & 5,8 & $3,2-12,5$ \\
\hline mokraća & 0,095 & $0,033-0,29$ \\
\hline pljuvačka & 1,8 & $0,36-4,8$ \\
\hline seminalna tečnost & 51,0 & $41,2-61,8$ \\
\hline amnionska tečnost & 1,0 & $0,8-1,4$ \\
\hline suze & 2,4 & $1,3-7,4$ \\
\hline mleko & 3,4 & $2,2-3,9$ \\
\hline
\end{tabular}


Koncentracija cistatina $\mathrm{C}$ u serumu je konstantna $(\sim 1 \mathrm{mg} / \mathrm{l})$ i ne zavisi od mišićne mase $\mathrm{i}$ pola $\mathrm{u}$ dobu od 1 do 50 godina. Kod starijih je pokazano da se njegova koncentracija ipak menja. Zbog porasta broja obolelih od hronične bubrežne bolesti važno je zapaziti rane znake oštećenja funkcije bubrega za šta, po mnogima, kreatinin nije najpogodniji $(59,60)$. Kliničari propuštaju da prepoznaju prve znake bubrežne disfunkcije prateći referentni interval kreatinina.

Naročito je važno prepoznati prve znake slabosti bubrega kod akutnog oštećenja bubrega, koje može da nastane kod hospitalizovanih bolesnika i ima visoku smrtnost, 30 $\%$ do $90 \%$ pa je vrlo važno sprečiti progresiju oštećenja (61-66). Pri akutnom oštećenju bubrega brzo opada JGF, a kreatinin zbog već iznetih ograničenja ne odražava dovoljno pouzdano brze promene JGF (67). Nekoliko autora je pokazalo da se u akutnoj bubrežnoj bolesti porast vrednosti cistatina $\mathrm{C}$ javlja dva dana ranije nego porast kreatinina, što može biti ključno za uspešnost prevencije progresije akutne bubrežne bolesti $(68,69)$.

Novije studije ukazuju na sve veći značaj cistatina $\mathrm{C}$ kao prediktivnog faktora kod kardiovaskularnih bolesti gde je on nezavistan prognostički marker. Renalna disfunkcija ima direktan uticaj na progresiju kardiovaskularnih bolesti i pokazano je da je povećan nivo cistatina $\mathrm{C}$ povezan sa većim mortalitetom kako kod hroničnog tako $\mathrm{i}$ kod akutnog oštećenja srca (70). Cistatin C je takođe superiorniji od drugih standardnih biomarkera bubrežne funkcije $\mathrm{u}$ predikciji rizika od smrtnog ishoda bolesnika sa akutnom insuficijencijom srca.

Koncentracija cistatina $\mathrm{C} u$ serumu je pouzdan marker za procenu JGF $\mathrm{u}$ pedijatrijskoj populaciji (71). Koncentracija fetalnog cistatina $\mathrm{C}$ ne zavisi od koncentracije cistatina $\mathrm{C}$ u krvi majke tako da on odražava funkciju bubrega neonatusa (72). Kod zdravih novorođenčadi nivo cistatina $\mathrm{C}$ u krvi ne zavisi od gestacione dobi rođenja, niti od telesne težine ili nivoa bilirubina, statistički je viši nego kod odraslih osoba i sazrevanjem bubrega i razvijanjem funkcije opada iz dana $u$ dan i dostiže vrednost odraslih (73). Studije su pokazale da je cistatin $\mathrm{C}$ jednak ili bolji od kreatinina za procenu JGF i da visoko korelira sa klirensom inulina jer odražava funkciju bubrega nezavisno od uzrasta, pola, težine, telesne kompozicije, što je važno u dečijem dobu (74-77). Cistatin C se koristi u pedijatrijskoj populaciji u jednačinama za izračunavanje JGF gde pouzdanost procene zavisi od primenjene jednačine (78). Pri odabiru prediktivnih jednačina neophodno je da se vodi računo o metodi kojom je određen cistatin C. U praksi se za procenu JGF primenjuju sledeće jednačine na bazi cistatina C: 
1. JGF $(\mathrm{ml} / \mathrm{min} / 1,73 \mathrm{~m} 2)=78 \times 1 /$ cistatin $\mathrm{C}(\mathrm{mg} / \mathrm{l})+4$

2. JGF $(\mathrm{ml} / \mathrm{min} / 1,73 \mathrm{~m} 2)=84,69 \times[$ cistatin $\mathrm{C}(\mathrm{mg} / \mathrm{l})]-1,680$

$\times[1,384$ za decu $<14$ god. $]$

3. JGF $(\mathrm{ml} / \mathrm{min} / 1,73 \mathrm{~m} 2)=87 \times[1 /$ cistatin $\mathrm{C}(\mathrm{mg} / \mathrm{l})]-6,9$

4. JGF $(\mathrm{ml} / \mathrm{min} / 1,73 \mathrm{~m} 2)=80,35 \times[1 /$ cistatin $\mathrm{C}(\mathrm{mg} / 1)]-4$

5. JGF $(\mathrm{mL} / \mathrm{min})=74,84 \times 1 /[\operatorname{cistatin} \mathrm{C}(\mathrm{mg} / \mathrm{l})] 1,33$

Korekcija jednačina se vrši odgovarajućim faktorom za izračunavanje JGF kod dece.

U dečijoj onkologiji od izuzetne važnosti je praćenje stanja bubrega. Upotreba serumskog kreatinina za procenu JGF je u ovoj populaciji bolesnika nepogodna zbog njegove zavisnosti od mišićne mase te može doći do precenjivanja JGF. Jednačine koje se zasnivaju na cistatinu $\mathrm{C}$ su se pokazale pouzdanije a adekvatnom kombinacijom jednačina baziranih na cistatinu $\mathrm{C}$ povećava se i specifičnost $(79,80)$.

Pokazano je da cistatin $\mathrm{C}$ dobro odražava JGF u postooperativnom praćenju funkcije transplantiranog bubrega (81). On je senzitivnji marker promena JGF od kreatinina u serumu, posebno tokom akutnog odbacivanja bubrega. U grupi odraslih transplantiranih primalaca duži niz godina posle transplantacije cistatin $\mathrm{C}$ je bio bolji dijagnostički pokazatelj stanja transplantiranog bubrega nego serumski kreatinin pri JGF $60 \mathrm{ml} / \mathrm{min}$, a klirens kreatinina je za preko $20 \%$ precenjivao JGF $(82,83)$. Samo u slučajevima snižene JGF cisatin C precenjuje JGF kod bolesnika sa transplantiranim bubregom (84).

U velikim broju studija je dokazana superiornost cistatina $\mathrm{C}$ nad kreatininom za procenu JGF u hroničnoj bubrežnoj insuficijenciji, zbog male varijabilnosti i jedinstvenog referntnog intervala koji ne zavisi od pola, strosti i pripadnosti etničkoj grupi. Pokazano je da je cistatin C posebno pogodan za otkrivanje blagih i umerenih poremećaja funkcije bubrega pri JGF između $60-90 \mathrm{~mL} / \mathrm{min} / 1,73 \mathrm{~m}^{2}$, odnosno može da detektuje poremećaje u ranom stadijumu hronične bubrežne bolesti kada se pomoću kreatinina ne mogu da otkriju poremećaji zbog povećane eliminacije kreatinina usled tubulske sekrecije (85-87).

Kod bolesnika sa dijabetesom se vrlo rano javlja disfunkcija bubrega. U nekim studijama je pokazano za bolesnike koji imaju dijabetes tip 1 da ni kreatinin u serumu ni klirens kreatinina nisu dovoljno osetljivi pri JGF većoj od $50 \mathrm{ml} / \mathrm{min}$. Poređenje klirensa Ioheksol i cistatina $\mathrm{C}$ dobijen je visok stepen slaganja i pokazano je da je cistatin $\mathrm{C}$ metod izbora za procenu JGF kod bolesnika sa dijabetesom tip 1 (88). Slični rezultati su 
dobijeni i za diabetes mellitus tip 2 (89). I kod drugih patoloških stanja kao što su reumatoidni artritis, ciroza jetre, multipli mijelom, kod bolesnika koji primaju nesteroidne antiflamatorne lekove cistatin $\mathrm{C}$ je superioran $\mathrm{u}$ odnosu na kreatinin za procenu JGF. Neki autori smatraju da je u trudnoći kako normalnoj tako i patološkoj i u preeklapsiji cistatin C pogodan za procenu JGF. Kod trudnica sa preeklampsijom u trećem trimestru nivoi beta-trace proteina, cistatina $\mathrm{C}$ i $\beta_{2}$ mikroglobulin $u$ plazmi su značajno viši u odnosu na zdrave trudnice, što ukazuje da su ovi proteini korisni biomarkeri renalne insuficijencije kod ovog poremećaja (90).

$\mathrm{U}$ svim navedenim stanjima cistatina $\mathrm{C}$ je potencijalno idealan endogeni marker JGF zbog konstantne stope stvaranja, koja ne zavisi od godina života, pola ili mišićne mase, slobodne filtracije u glomerulima zbog male molekulske mase i baznog $\mathrm{pH}$, kompletne reapsorpcije i katabolizma u ćelijama proksimalnih tubula, izostanka renalne tubularne sekrecije i reapsorpcije u krvotok. Nivo cistatin $\mathrm{C}$ u cirkulaciji za razliku od kreatinina ne zavisi od unosa belančevima, starenja i inflamacije $(91,92)$.

Smatra se da na dijagnostičku osetljivost cistatina $\mathrm{C}$ utiče maligna progresija jer $\mathrm{u}$ tim stanjima on ima ulogu u remodeliranju obolelog tkiva, invaziji i metastaziranju kancera (93). Koncentracije cistatina C u serumu bolesnika sa kolorektalnim karcinomom ili metastaznim melanomom bez oboljenja bubrega su značajno više nego kod pacijenata sa primarnim melanomom, pa se smatra da je to izazvano ubrzanim ćelijskim ciklusom melanocita, nezavisno od JGF. Postoje još neka patološka stanja gde cistatin C nije bolji od serumskog kreatinina za procenu JGF kao što su terapija glukokortikoidima i tiroidna bolest (94).

Koncentracija cistatina $\mathrm{C}$ u biološkim fluidima je niska pa su za njegovu detekciju neophodne visoko specifične i senzitivne metode. Prvi test za kvantifikaciju cistatina $\mathrm{C}$, kompetitivni radioimunoesej (Radioimmunoassay, RIA) sa granicom detekcije od 300 $\mu \mathrm{g} / \mathrm{l}$, razvili su 1979. godine Löfberg $i$ Grubb. On omogućava detekcija cistatina C u serumu zdravih individua i analizu vrednosti cistatina C. Druge metode za detekciju cistatina $\mathrm{C}$ zasnovane su na fluorescentnim i enzimskim imunološkim testovima sa opsegom detekcije od 0,13 do 1,9 $\mu \mathrm{g} / \mathrm{l}$. Do 1994. godine određivanje nivoa cistatina $\mathrm{C} \mathrm{u}$ serumu nije imalo veći dijagnostički značaj zbog poteškoća u standardizaciji imunohemijskih metoda. Visoku specifičnost i osetljivost imaju automatizovana homogena imunoodređivanja, u kojima se koriste čestice od lateksa ili polistirena za koje su vezana cistatin C-specifična antitela, zasnovana na turbidimetriji (Particleenhanced turbidimetric immunoassay, PETIA) ili nefelometriji (Particle-enhanced 
nephelometric immunoassay, PENIA). PETIA metod daje rezultate koji su za $20 \%-30$ \% viši od onih dobijenih PENIA metodom, dok je korelacija između JGF i recipročne vrednosti cistatina $C$ veća kada se cistatin $C$ meri PENIA metodom nego ostalima (95). Početna ograničenja upotrebe cistatina $\mathrm{C}$ u kliničkoj praksi su bila vezana za problem standardizacije mernih procedura. Radna grupa za standardizaciju cistatina C pri IFCC (International Federation of Clinical Chemistry and Laboratory Medicine) je razvila referentni materijal koji je sada dostupan u Institutu za referentne materijale i mere u Belgiji i označen je kao ERM-DA471/IFCC.

Kada se sve aktivnosti oko standardizacije određivanja cistatina $\mathrm{C}$ završe očekuje se prevazilaženje problema koji sada postoje u preciznom praćenju funkcije bubrega upotrebom cistatina $\mathrm{C}$ kod nekih populacionih grupa kao što su deca ili starije osobe. Standardizacija će dovesti do ispravljanja formula kojima se izračunava JGF i na taj način će cistatin C bolje da odražava stvarnu vrednost JGF (96-100). 


\section{CILJ RADA}

Bolest i slabost bubrega imaju ireverzibilan i progresivan tok koji vodi ka razvoju terminalne hronične bubrežne slabosti. Ulažu se napori da se nađe što jednostavniji, brži i pouzdaniji parametar jačine glomerulske filtracije pa i ovaj rad predstavlja doprinos tom procesu kroz sledeće ciljeve:

1. da se utvrdi da li je cistatin $\mathrm{C}$ pouzdan pokazatelj jačine glomerulske filtracije, tj. da se utvrdi u kakvoj je on vezi sa klirensom ${ }^{99 \mathrm{~m}}$ Tc-DTPA,

2. da li je cistatin C pouzdan pokazatelj jačine glomerulske filtracije, tj. da se utvrdi u kakvoj je on vezi sa kreatininom u serumu i klirensom kreatinina,

3. da se utvrdi kako životna dob utiče na nivo cistatina $C$,

4. da se ispita da li je cistatin C osetljiviji pokazatelj početnog oštećenja jačine glomerulske filtracije od kreatinina,

5. da li je cistatin $\mathrm{C}$ dobar pokazatelj jačine glomerulske filtracije kod obolelih od nefrotskog sindroma $\mathrm{i}$ da se utvrdi kako proteinurija i životna dob bolesnika utiče na nivo cistatina $\mathrm{C}$ u serumu.

6. da se utvrdi da li je cistatin C dobar pokazatelj JGF kod osoba sa endemskom nefropatijom,

7. da se utvrdi da li je cistatin $\mathrm{C}$ dobar pokazatelj jačine glomerulske filtracije kod obolelih od dijabetesa tipa 2 ,

8. da se utvrdi kako gestacioni periodi trudnica sa normalnim bubrežnom funkcijom utiču na nivo cistatina $C$,

9. da se utvrdi kako životna dob trudnica utiče na nivo cistatina $C$,

10. da se ustanovi odnos nivoa cistatina $C$, serumskog kreatinina i klirensa kreatinina $\mathrm{u}$ različitim gestacionim periodima kako $\mathrm{u}$ normalnoj tako $\mathrm{i} \mathrm{u}$ trudnoći komplikovanoj PIH i da se utvrdi da li cistatin $\mathrm{C}$ u ovoj grupi može da se koristi kao marker jačine glomerulske filtracije. 


\section{ISPITANICI I METODE}

\subsection{ISPITANICI}

Ovo ispitivanje je sprovedeno kao studija preseka u periodu od 2006. do 2010. godine.

Sva ispitivanja su sprovedena $\mathrm{u}$ skladu sa Helsinškom deklaracijom o medicinskim istraživanjima i uz odobrenje Etičkog komiteta Medicinskog fakulteta $\mathrm{u}$ Beogradu. Sva laboratorijska ispitivanja su urađena u laboratorijama Centra za medicinsku biohemiju Kliničkog centra Srbije.

Jedan od ciljeva ovog rada je bio da se ustanovi da li cistatin $C$ može da se primeni za procenu JGF. Zbog toga je u periodu od 2006. do 2008. godine formirana grupa od 62 bubrežna bolesnika (BB) koji su imali različiti stepen jačine glomerulske filtracije. Svima je izotopski određena JGF kao klirens ${ }^{99 m}$ Tc-DTPA, a zatim i koncentracija cistatina $\mathrm{C}$ i kreatinina u serumu. Da bi se utvrdilo kakav je stepen povezanosti vrednosti cistatina $\mathrm{C}$ i kreatinina $u$ serumu $i$ klirensa ${ }^{99 \mathrm{~m}} \mathrm{Tc}-$ dietilentriaminpentasirćertne kiseline $\left({ }^{99 \mathrm{~m}}\right.$ Tc-DTPA) izvršena je korelaciona analiza.

U skladu sa definisanim ciljevima urađeno je, uz poštovanje Helsinške deklaracije o medicinskim istraživanjima i predhodno dobijenu pisanu saglasnost, i ispitivanje 109 trudnica. Sve su bile zdrave, bez hipertenzije pre i tokom trudnoće, bez dijabetesa $\mathrm{i}$ bolesti bubrega i nosile su jedno dete. Ispitivanja su vršena u preostalim alikvotima krvi koja je uzimana za rutinske laboratorijske analize pri redovnom kontrolnom pregledu trudnica u Klinici za ginekologiju i akušerstvo Kliničkog centra Srbije u periodu od 2008. do 2010. godine. Određivanje koncentracije cistatina C rađeno je u Službi za polikliničku laboratorijsku dijagnostiku, dok je određivanje kreatinina u serumu kao i klirensa kreatinina rađeno u Službi za kliničku laboratorijsku dijagnostiku u Odeljenju biohemijske laboratorije na Klinici za ginekologiju i akušerstvo. Da bi se posmatrala direktna srazmera JGF izračunavana je recipročna vrednost cistatina $\mathrm{C}$ (1/ cistatin $\mathrm{C})$. Trudnice su prema stadijumu trudnoće podeljene u tri gestacina perioda.

Kako je hipertenzija moguća prateća komplikacija trudnoće jedan od ciljeva ovog rada je bio da se odredi cistatin $\mathrm{C}$ trudnicama koje su imale hipertenziju izazvanu 
trudnoćom (PIH) i da se utvrdi da li kod njih cistatin C može da bude dobar pokazatelj JGF. U ovu svrhu formirana je grupa od 33 trudnice kojima je klinički postavljena dijagnoza PIH i određivani su im isti parametri kao i trudnicama sa nekomplikovanim tokom trudnoće. Za ispitivanja su upotrebljeni preostali alikvoti krvi koja je uzimana za rutinske laboratorijske analize tokom njihovog lečenja u Klinici za ginekologiju i akušerstvo Kliničkog centra Srbije u periodu od 2008. do 2010. godine.

Da bi se utvrdile vrednosti ispitivanih parametara kod obolelih od endemske nefropatije sprovedeno je ispitivanje 57 osoba sa endemskom nefropatijom koji su ispitivani i lečeni u Specijalnoj bolnici za endemsku nefropatiju u Lazarevcu. Kao izvori podataka korišćeni su i kartoni obaveznih prijava bubrežnih oboljenja, kao i medicinska dokumentacija a ispitana im je vrednost cistatina $\mathrm{C}$, kreatinina i klirensa kreatinina.

Svi ispitanici su podeljeni u četiri grupe u zavisnosti od utvrđene vrednosti klirensa kreatinina:

-I grupa obuhvata osobe sa vrednostima klirensa kreatinina od 1 do 39,9 ml/min -II grupa ispitanika je sa vrednostima klirensa kreatinina od $40 \mathrm{ml} / \mathrm{min}$ do $79,9 \mathrm{ml} / \mathrm{min}$ -III gupa ispitanika je sa vrednostima klirensa kreatinina od od 80 do $119,9 \mathrm{ml} / \mathrm{min}$ -IV grupa obuhvata osobe sa vrednostima klirensa kreatinina preko $120 \mathrm{ml} / \mathrm{min}$.

Jedan od ciljeva ovog rada je bio da se ispitaju vrednosti cistatina $\mathrm{C}$, kreatinina $\mathrm{i}$ klirensa kreatinina kod bolesnika sa nefrotskim sindromom.

Vrednosti posmatranih parametara su ispitani kod 30 bolesnika čija je proteinurija bila preko 3,5 g/24 sata. Grupu je činilo 16 muškarac i 14 žena prosečne strosti 47,2 $\pm 12,72$ godine. Kontrolnu grupu je činilo 15 zdravih osoba od kojih je bilo 6 muškaraca i 9 žena, prosečne starosti $37,27 \pm 5,48$ godina.

Ispitana je i mogućnost procene JGF pomoću cistatina $\mathrm{C}$ kod obolelih od Diabetes mellitus-a. Ispitivanje je obuhvatilo 31 bolesnika koji su kao osnovnu bolest imali Diabetes mellitus tip 2 i svi su uz to imali i druge različite bolesti bilo kao posledicu već prisutnog Diabetes mellitus ili nezavisno kao prateću bolest. 


\subsection{METODE ISPITIVANJA}

Za sva ispitivanja uzorci krvi i mokraće uzimani su ujutru. Uzorak 24h urina sakupljan je od 6h ujutro prvog dana do 6h ujutro narednog dana. Uzorci venske krvi su sakupljani u vakutajnerima (BD) bez aditiva, centrifugirani na $3500 \mathrm{rpm},(\approx 2000 \mathrm{~g}) \mathrm{i}$ posle separacije serum je čuvan na minus $80{ }^{\circ} \mathrm{C}$ do određivanja.

\subsubsection{Određivanje koncentracije kreatinina}

Kreatinin u serumu i u uzorku 24-satne mokraće (sa deset puta većim razblaženjem) je određivan kinetičkom metodom sa alkalnim pikratom komercijalnim kitovima firme Olympus (Hamburg, Germany) na automatskom analizatoru Olympus 640. Kreatinin u uzorku reaguje sa pikrinskom kiselinom u alkalnoj sredini gradeći žuto-narandžasti kompleks kreatinin-pikrata. Brzina porasta apsorbance reakcione smeše se meri na 500 $\mathrm{nm}$ i proporcionalna je koncentraciji kreatinina $\mathrm{u}$ uzorku. Referentni interval za kreatinin u serumu je za muškarce 58-110 $\mu \mathrm{mol} / 1$, a za žene 45-84 $\mu \mathrm{mol} / 1$. Klirens kreatinina je izračunavan na osnovu formule koja predstavlja količnik proizvoda koncentracije kreatinina $\mathrm{u}$ urinu i zapremine sakupljenog urina sa jedne strane $\mathrm{i}$ koncentracije kreatinina u serumu sa druge. Odnos je dat za standardnu površinu ljudskog tela koji iznosi $1,73 \mathrm{~m}^{2}$ i izražen je u $\mathrm{ml} / \mathrm{min}$

\subsubsection{Određivanje koncentarcije cistatina $C$}

Cistatin $\mathrm{C}$ u serumu je određivan PENIA metodom (Particle-Enhancesd Nephelometric Immuno-Assay) testovima firme Dade Behring (Marburg, Germany) na laserskom nefelometru (BN II Dade Behring). U ovom testu polistirenske čestice hemijski kuplovane zečjim antitelima na humani cistatin $\mathrm{C}$ aglutinišu kada se pomešaju sa uzorkom koji sadrži cistatin C. Antigen-antitelo kompleksi rasipaju upadnu svetlost (poreklom od diode) talasne dužine od $840 \mathrm{~nm}$. Intenzitet rasute svetlosti u nefelometru proporcionalan je koncentraciji cistatina $\mathrm{C}$ (antigen) u uzorku koja se određuje interpolacijom na kalibracionoj krivi. Donja granica detekcije je 0,05 mg/l. Normalna 
koncentracija cistatina $\mathrm{C}$ u serumu po proizvođačkoj deklaraciji za ovu metodu iznosi $0,53-0,95 \mathrm{mg} / \mathrm{l}$.

\subsubsection{Određivanje ukupnih proteina u urinu}

Proteinurija iz uzorka 24-satne mokraće je određena kolorimetrijskom metodom sa pyrogallol red bojom komercijalnim testovima na automatskom analizatoru Olympus 640. Princip testa se zasniva na formiranju kompleksa crvene boje između pyrogallol red i molibdata koji se vezuje za amino grupe molekula proteina, posle čega se menja boja reakcionog sistema u plavo-ljubičastu. Ovaj obojeni kompleks ima maksimum apsorbance na $600 \mathrm{~nm}$ i apsorbanca je direktno proporcionalna koncentraciji proteina $\mathrm{u}$ posmatranom uzorku urina. Metoda je linearna u opsegu $0,01-2,0 \mathrm{~g} / \mathrm{l}$. Za nivo proteina preko 2,0 g/l vršeno je adekvatno razblaživanje fiziološkim rastvorom. Referentne vrednosti za proteine u urinu su $<0,30 \mathrm{~g} / \mathrm{dan}$.

\subsubsection{Određivanje JGF primenom dinamske scintigrafije}

Dinamska scintigrafija bubrega je urađena tokom šest minuta posle intravenskog ubrizgavanja standardne doze $222 \mathrm{MBq}$ (Bg-Becquerel), dietilentriaminopentaacetatne kiseline (DTPA) obeležene izotopom (99m) tehnicijuma $\left({ }^{99 \mathrm{~m}}\right.$ Tc-DTPA). Snimanje je obavljeno $\gamma$-scintilacionom kamerom, Siemens Orbiter 7500 (Siemens Gamma Sonics, Inc, Hoffman Estates, Illinois, USA) gde su bolesnici bili u ležećem položaju a kamera je postavljena ispod njih. Područje bubrega i bešike su postavljeni u centar fokusa gama kamere. Aktivnost šprica kojim je ubrizgana ${ }^{99 \mathrm{~m}}$ Tc-DTPA je izmerena pre i posle injekcije i ta razlika predstavlja datu dozu. Posle injekcije ${ }^{99 m}$ Tc-DTPA tokom 6 minuta scintigrafijski snimci i kompjuterski prerađene krive za aktivnosti po vremenu posle oduzimanja pozadinskih efekata su analizirane. Komercijalnim programom proizvođača izračunato je koliko su ${ }^{99 \mathrm{~m}}$ Tc-DTPA preuzeli bubrezi, ubačene su vrednosti za visinu i težinu bolesnika i jačina glomerulske filtracije (JGF) je kompjuterski određena na osnovu Gatesovog algoritma (101). 


\subsection{STATISTIČKA ANALIZA}

Rezultati istraživanja su prikazani tabelarno i grafički. Korišćene su statističke tabele distribucije frekvencija, kao i neposredna analiza tabelarnih podataka i analiza na osnovu grafičkog prikazivanja. Prikazani podaci, bilo u apsolutnim ili relativnim brojevima služili su za uočavanje karakteristika i donošenje zaključaka.

Od statističkih metoda primenjene su srednja vrednost, standardna devijacija, koeficijent varijacije kao i medijana i percentilne vrednosti. Podaci su prikazani tabelarno i uz grafičku obradu statističkim metodama deskriptivne statistike.

U uslovima gde posmatrane grupe nisu imale normalnu raspodelu (KolmogorovSmirnov test), korišćeni su neparametarski testovi za poređenje, Mann-Whitney test i Spearmanov test za korelacionu analizu. Za testiranje podataka koji su imali normalnu raspodelu korišćen je Student t-test i parametarska korelaciona analiza, Pearsonov test. Za testiranje značajnosti razlike obeležja korišćen je Univarijantni metod-analiza varijanse - ANOVA test.

Za testiranje značajnosti razlike posmatranih varijabli korišćen je LSD test za multu komparaciju. Za testiranje korelacija između odabranih varijabli korišćen je LSD test za multu komparaciju. Statistička obrada i analiza urađena je u SPSS-u ver.12.0, a grafičko i tabelarno prikazivanje urađeno je u MICROSOFT OFFICE-u. 


\section{REZULTATI}

\subsection{REZULTATI ODREĐIVANJA KLIRENSA ${ }^{99 \mathrm{~m}}$ Tc-DTPA, KREATININA I CISTATINA C KOD BOLESNIKA SA RAZLIČITIM BOLESTIMA BUBREGA}

Jedan od ciljeva ovog rada je bio da se ustanovi da li cistatin C može da se primeni za procenu JGF. Zato je formirana grupa od 62 bubrežna bolesnika (BB) koji su bili različite životne dobi. Bilo je 26 (41,9 \%) muškaraca i 36 (58,1 \%) žena. Nije nađena statistički značajna razlika u zastupljenosti bolesnika prema polu $(\chi 2=1,613$ $\mathrm{p}=0,201)($ Slika 6).

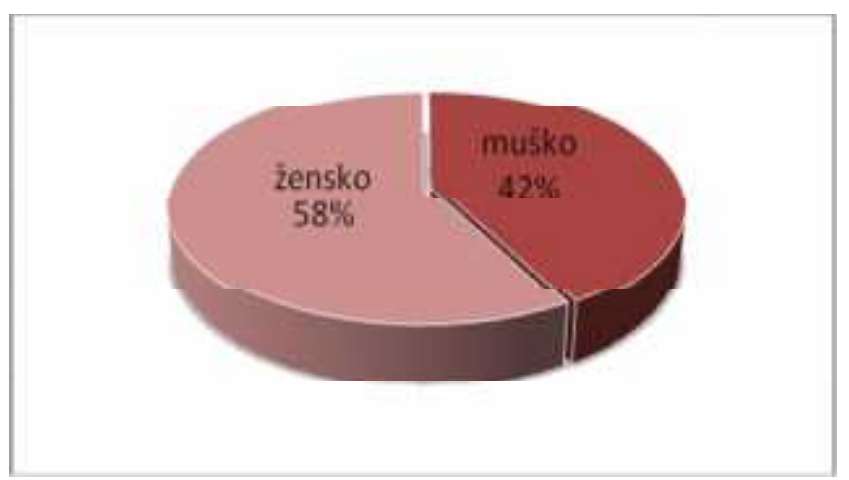

Slika 6. Distribucija bolesnika prema polu

Prosečna starost bolesnika obuhvaćenih istraživanjem bila je 45,04 $\pm 12,88$ godina. Najmlađi bolesnik je imao 18 godina, a najstariji 71 godinu.

Tabela 3. Prosečna starost bolesnika obuhvaćenih istraživanjem prema polu

\begin{tabular}{|c|c|c|c|c|c|c|c|}
\hline \multirow[b]{2}{*}{ pol } & \multirow[b]{2}{*}{$\mathrm{N}$} & \multirow{2}{*}{$\begin{array}{c}\text { Prosek } \\
\text { (godine) }\end{array}$} & \multirow[b]{2}{*}{ SD } & \multicolumn{2}{|c|}{ 95\% interval pouzdanosti } & \multirow[b]{2}{*}{ Min. } & \multirow[b]{2}{*}{ Maks. } \\
\hline & & & & donja & gornja & & \\
\hline muško & 26 & 44,18 & 12,50 & 38,64 & 49,72 & 20,00 & 70,00 \\
\hline žensko & 36 & 45,86 & 13,46 & 40,05 & 51,69 & 18,00 & 71,00 \\
\hline ukupno & 62 & 45,04 & $\overline{12,88}$ & 41,17 & 48,91 & $\overline{18,00}$ & $\overline{71,00}$ \\
\hline
\end{tabular}

Prosečna starost muškaraca obuhvaćenih istraživanjem u ovoj grupi iznosila je $44,18 \pm 12,50$ godina. Najmlađi bolesnik imao je 20 godina, a najstariji 70 godina. 
Prosečna starost žena u ovoj grupi bolesnika bila 45,86 $\pm 13,46$ godina. Najmlađa bolesnica imala je 18 godina, a najstarija 71 godinu (Tabela 3).

Bolesnici su imali različiti stepen jačine glomerulske filtracije. Svima je određen klirens ${ }^{99 \mathrm{~m}}$ Tc-DTPA, koncentracija cistatina $\mathrm{C}$ i kreatinina u serumu. Da bi se utvrdilo $\mathrm{u}$ kom stepenu su povezane vrednosti cistatina C i kreatinina u serumu i klirensa ${ }^{99 \mathrm{~m}} \mathrm{Tc}$ dietilentriaminpentasirćertne kiseline $\left({ }^{99 \mathrm{~m}}\right.$ Tc-DTPA) izvršena je korelaciona analiza.

\subsubsection{Vrednosti klirensa ${ }^{99 m}$ Tc-DTPA, koncentracije kreatinin i cistatina $\mathrm{C} u$ serumu i recipročne vrednosti cistatina $C$ kod bubrežnih bolesnika}

Prosečna koncentracija kreatinina u serumu ispitivanih bolesnika bila je $87,40 \pm$ $20,85 \mu \mathrm{mol} / \mathrm{l}$. Kod muškaraca je iznosila $99,42 \pm 22,13 \mu \mathrm{mol} / 1$, dok je kod žena iz ove grupe vrednost kreatinina u serumu iznosila u proseku 78,72 $\pm 14,94 \mu \mathrm{mol} / 1$ (Tabela 4).

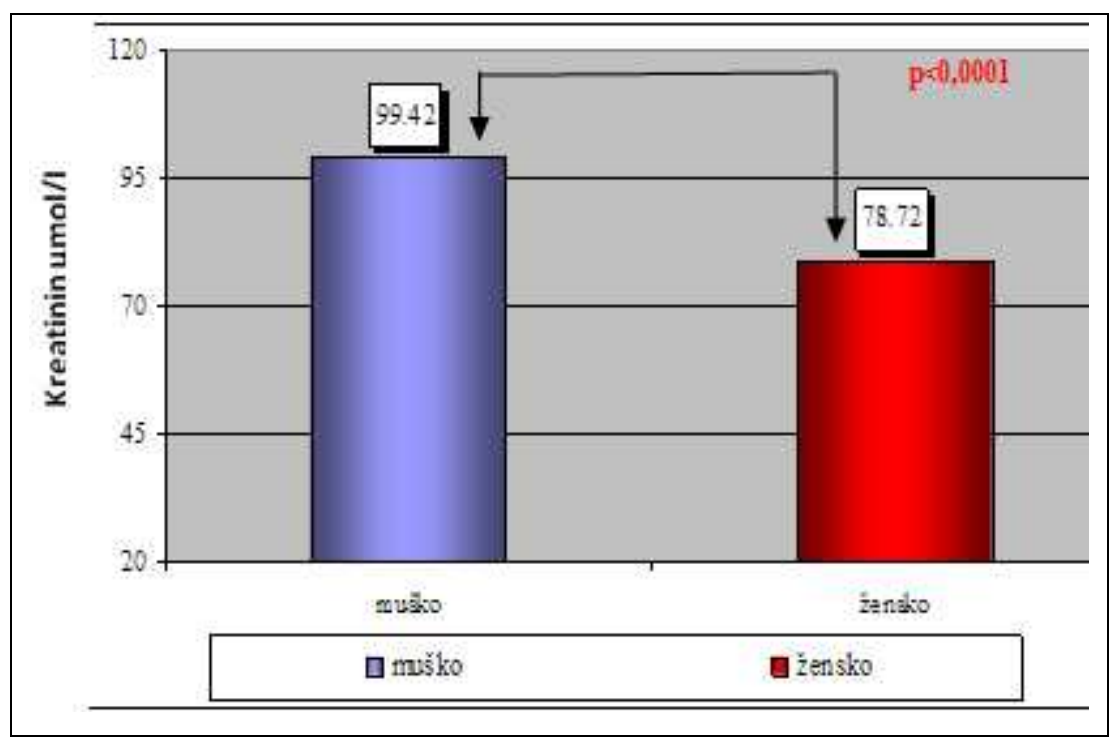

Slika 7. Prosečna vrednost kreatinina u serumu prema polu

Očigledno je da su vrednosti kreatinina u serumu bile statistički značajno više kod muškaraca nego kod žena $(\mathrm{F}=19,34 \mathrm{p}<0,0001)$ (Slika 7). Prosečna vrednost klirensa ${ }^{99 \mathrm{~m}}$ Tc-DTPA bila je 97,83 $\pm 23,61 \mathrm{ml} / \mathrm{min}$. Vrednosti su bile približne kod oba pola, nije dokazano da postoji statistički značajna razlika $(\mathrm{F}=0,223 \mathrm{p}=0,629)$ (Tabela 4). 
Tabela 4. Distribucija prosečnih vrednosti klirensa ${ }^{99 \mathrm{~m}}$ Tc-DTPA, koncentracije kreatinin i cistatina $\mathrm{C}$ u serumu i recipročne vrednosti cistatina $\mathrm{C}$ kod bubrežnih bolesnika

\begin{tabular}{|c|c|c|c|c|c|c|c|c|}
\hline \multirow{2}{*}{\multicolumn{2}{|c|}{ Parametar }} & \multirow{3}{*}{$\begin{array}{c}\mathrm{N} \\
26\end{array}$} & \multirow{3}{*}{$\begin{array}{l}\text { Prosek } \\
99,42\end{array}$} & \multirow{3}{*}{$\begin{array}{c}\text { SD } \\
22,13\end{array}$} & \multicolumn{2}{|c|}{ 95\% Granice pouzdanosti } & \multirow{3}{*}{$\begin{array}{l}\text { Min. } \\
69,00\end{array}$} & \multirow{3}{*}{$\begin{array}{l}\text { Maks. } \\
169,00\end{array}$} \\
\hline & & & & & \multirow{2}{*}{$\begin{array}{c}\begin{array}{c}\text { donja } \\
\text { granica }\end{array} \\
90,49\end{array}$} & \multirow{2}{*}{$\begin{array}{l}\begin{array}{c}\text { gornja } \\
\text { granica }\end{array} \\
108,36\end{array}$} & & \\
\hline Kreatinin & muško & & & & & & & \\
\hline u serumu & žensko & 36 & 78,72 & 14,94 & 73,67 & 83,78 & 49,00 & 120,00 \\
\hline$(\mu \mathrm{mol} / 1)$ & Ukupno & 62 & 87,40 & 20,85 & 82,11 & 92,70 & 49,00 & 169,00 \\
\hline \multirow{3}{*}{$\begin{array}{c}\text { 99m } \text { Te-DTPA } \\
(\mathrm{ml} / \mathrm{min})\end{array}$} & muško & 26 & 96,08 & 25,99 & 85,58 & 106,58 & 48,40 & 162,00 \\
\hline & žensko & 36 & 99,09 & 22,03 & 91,64 & 106,55 & 52,90 & 130,70 \\
\hline & Ukupno & 62 & 97,83 & 23,61 & 91,83 & 103,83 & 48,40 & 162,00 \\
\hline \multirow{3}{*}{$\begin{array}{c}\text { Cistatin C } \\
(\mathrm{mg} / \mathrm{l})\end{array}$} & muško & 26 & 0,93 & 0,23 & 0,84 & 1,02 & 0,64 & 1,61 \\
\hline & žensko & 36 & 0,86 & 0,24 & 0,78 & 0,94 & 0,48 & 1,35 \\
\hline & Ukupno & 62 & $\mathbf{0 , 8 9}$ & $\mathbf{0 , 2 3}$ & $\mathbf{0 , 8 3}$ & 0,95 & $\mathbf{0 , 4 8}$ & 1,61 \\
\hline \multirow{3}{*}{ 1/cistatin C } & muško & 26 & 1,13 & 0,24 & 1,03 & 1,23 & 0,62 & 1,56 \\
\hline & žensko & 36 & 1,26 & 0,34 & 1,14 & 1,37 & 0,74 & 2,08 \\
\hline & Ukupno & 62 & 1,20 & $\mathbf{0 , 3 1}$ & 1,12 & 1,28 & 0,62 & 2,08 \\
\hline
\end{tabular}

Kod muškaraca je prosečna vrednost klirensa ${ }^{99 m}$ Tc-DTPA bila 96,08 $\pm 25,99$ $\mathrm{ml} / \mathrm{min}$ dok je kod žena bila 99,09 $\pm 22,03 \mathrm{ml} / \mathrm{min}$ (Slika 8 ).

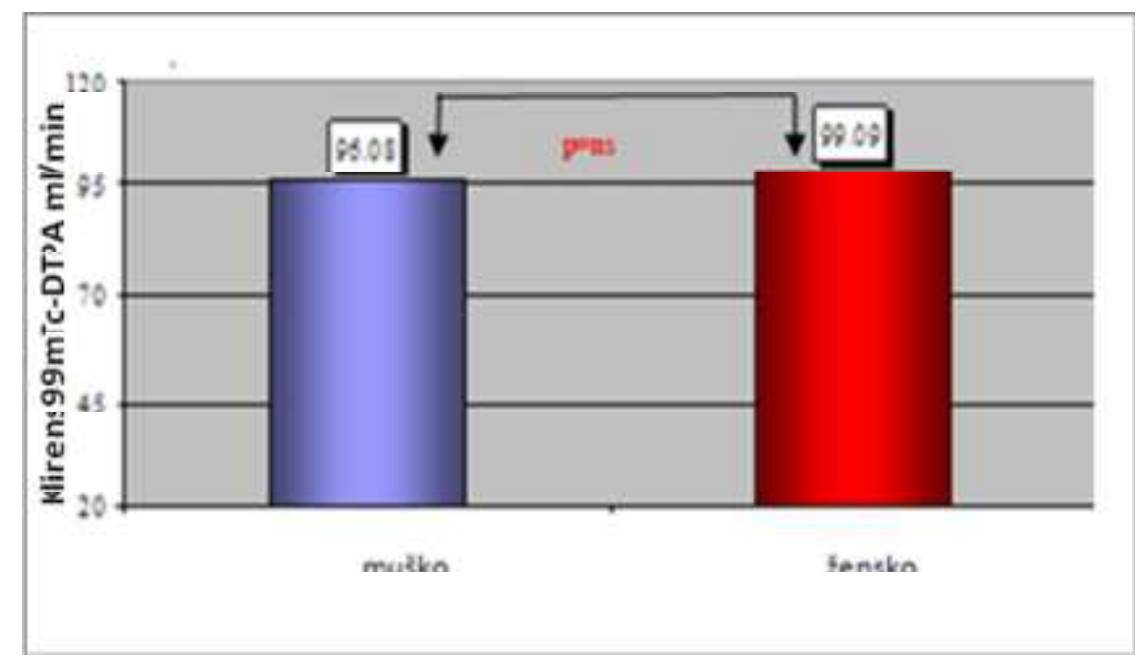

Slika 8. Prosečna vrednost klirensa ${ }^{99 \mathrm{~m}}$ Tc-DTPA prema polu 


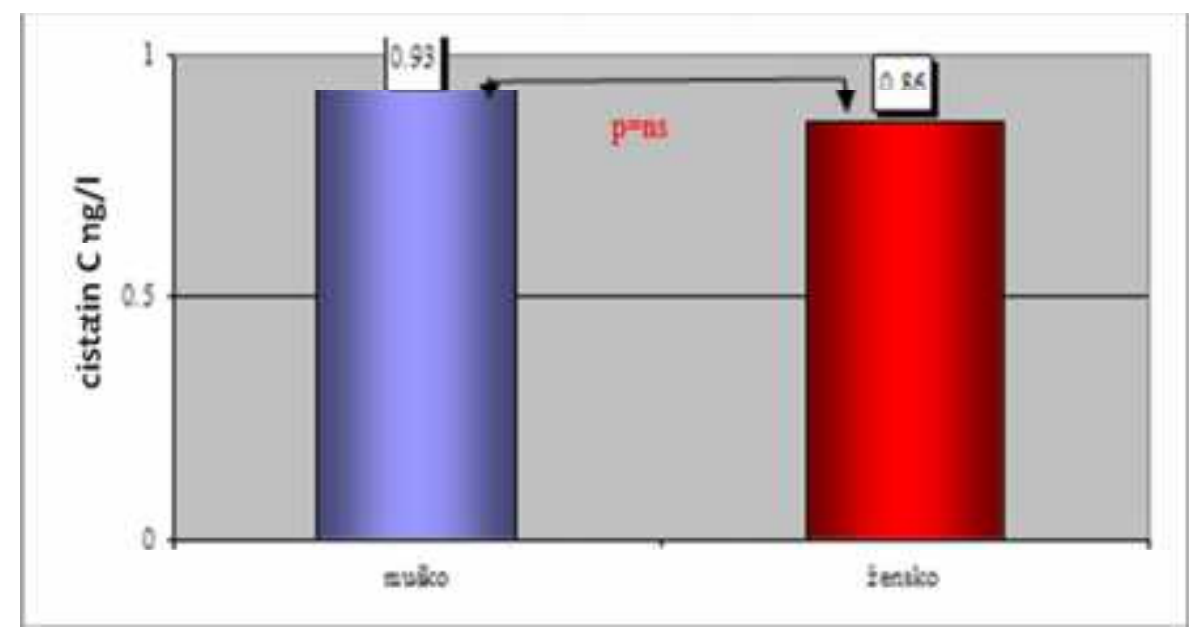

Slika 9. Prosečna vrednost cistatina C prema polu

Prosečni nivo cistatina $\mathrm{C}$ kod muškaraca iznosio je $0,93 \pm 0,23 \mathrm{mg} / \mathrm{l}$ dok je kod žena nivo cistatina $\mathrm{C}$ bio $0,86 \pm 0,24 \mathrm{mg} / \mathrm{l}$. Mada su muškarci imali više vrednosti nije dokazana statistički značajna razlika u nivou cistatina $\mathrm{C}$ u odnosu na pol bolesnika $(\mathrm{F}=1,494 \mathrm{p}=0,226)($ Slika 9).

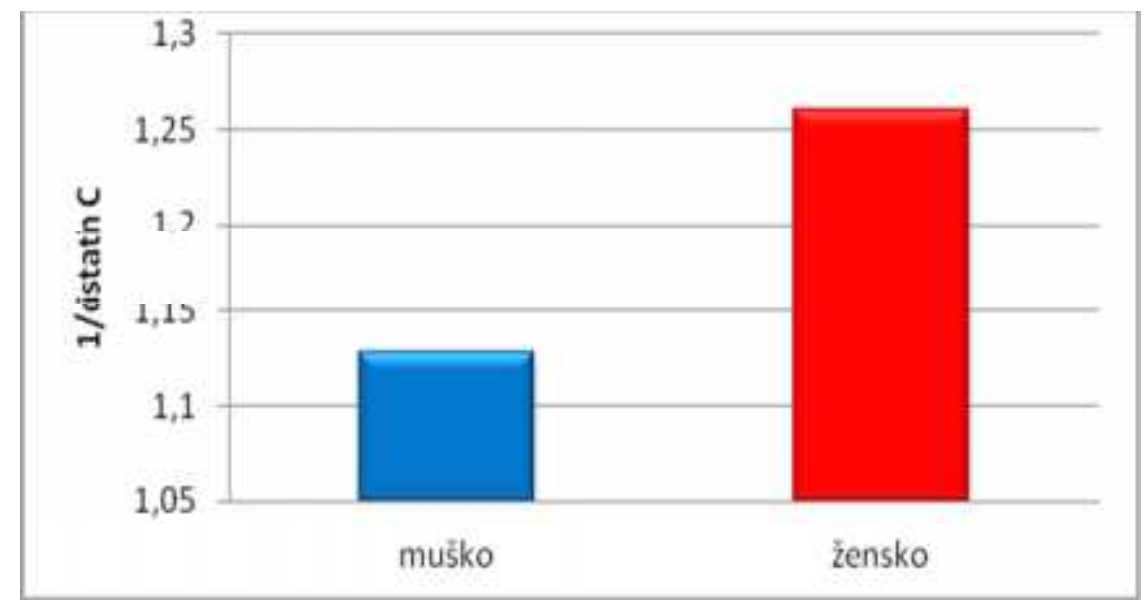

Slika 10. Prosečna vrednost $1 /$ cistatin $C$ prema polu

Kao što se moglo pretpostaviti, recipročne vrednosti cistatina $\mathrm{C}$ bile su niže kod muškarca, a ANOVA testom nije dokazana statistički značajna razlika između recipročnih vrednosti cistatina $\mathrm{C}$ muškaraca i žena u studiji $(\mathrm{F}=2,591 \mathrm{p}=0,118)($ Slika 10). 


\subsubsection{Korelacija nivoa klirensa ${ }^{99} \mathrm{~m}_{\text {Tc-DTPA sa koncentracijama kreatinina } \mathrm{i}}$ cistatina $C$ u serumu i recipročnim vrednostima cistatina $C$ kod bubrežnih bolesnika}

Da bi se ispitala povezanost klirensa ${ }^{99 \mathrm{~m}}$ Tc-DTPA sa koncentracijom kreatinina $\mathrm{i}$ cistatina $\mathrm{C}$ u serumu, kao i sa recipročnom vednošću cistatina $C$ (1/cistatin $C)$ određeni su koeficijenti korelacije.

Kreatinin u serumu obrnuto, statistički značajno korelira sa klirensom ${ }^{9 \mathrm{~m}}$ Tc-DTPA $(\mathrm{p}<0,001)$, kada raste kreatininemija značajno opada klirens ${ }^{99 \mathrm{~m}}$ Tc-DTPA (Tabela 5).

Tabela 5. Korelacija nivoa klirensa ${ }^{99 \mathrm{~m}}$ Tc-DTPA sa koncentracijama kreatinina $i$ cistatina $\mathrm{C}$ u serumu i recipročnim vrednostima cistatina $\mathrm{C}$ bolesnika sa $\mathrm{BB}$

\begin{tabular}{|c|c|c|c|c|c|}
\hline & & $\begin{array}{c}\text { Kreatinin } \\
\text { u serumu } \\
(\mu \mathrm{mol} / \mathrm{l})\end{array}$ & $\begin{array}{c}\text { Klirens } \\
{ }^{99 \mathrm{~m}} \text { Tc-DTPA } \\
(\mathrm{ml} / \mathrm{min}) \\
\end{array}$ & $\begin{array}{c}\text { Cistatin C } \\
(\mathrm{mg} / \mathrm{l})\end{array}$ & 1/Cistatin C \\
\hline \multirow{3}{*}{$\begin{array}{c}\text { Kreatinin } \\
\text { u serumu } \\
(\mu \mathrm{mol} / \mathrm{l})\end{array}$} & $\mathrm{R}$ & 1 & $-0,408(* *)$ & $0,599(* *)$ & $-0,543(* *)$ \\
\hline & Sig. $p$ & & 0,001 & 0,000 & 0,000 \\
\hline & Broj & 62 & 62 & 62 & 62 \\
\hline \multirow{3}{*}{$\begin{array}{c}\text { Klirens } \\
{ }^{\text {99m }} \text { Tc-DTPA } \\
(\mathrm{ml} / \mathrm{min})\end{array}$} & $\bar{R}$ & $-0,408(* *)$ & 1 & $-0,419(* *)$ & $0,401(* *)$ \\
\hline & Sig. $p$ & 0,001 & & 0,001 & 0,001 \\
\hline & Broj & 62 & 62 & 62 & 62 \\
\hline \multirow{3}{*}{$\begin{array}{c}\text { Cistatin C } \\
(\mathrm{mg} / \mathrm{l})\end{array}$} & $\mathrm{R}$ & $0,599(* *)$ & $-0,419(* *)$ & 1 & $-0,946(* *)$ \\
\hline & Sig. $p$ & 0,000 & 0,001 & & 0,000 \\
\hline & Broj & 62 & 62 & 62 & 62 \\
\hline \multirow[t]{3}{*}{ 1/cistatin $\mathrm{C}$} & $\overline{\mathrm{R}}$ & $-0,543(* *)$ & $0,401(* *)$ & $-0,946(* *)$ & 1 \\
\hline & Sig. $p$ & 0,000 & 0,001 & 0,000 & \\
\hline & Broj & 62 & 62 & 62 & 62 \\
\hline
\end{tabular}

** $\mathrm{p}<0,01$ postoji značajna korelacija među parametrima

Nivo kreatinina u serumu direktno statistički visoko značajno korelira sa koncentracijom cistatina $\mathrm{C}(\mathrm{p}<0,0001)$, sa porastom kreatininemije značajno češće raste nivo cistatina $\mathrm{C}$.

Vrednost klirensa ${ }^{99 \mathrm{~m}}$ Tc-DTPA obrnuto, statistički visoko značajno korelira sa nivoom cistatina $\mathrm{C}(\mathrm{p}<0,001)$, sa rastom klirensa ${ }^{99 \mathrm{~m}}$ Tc-DTPA opada vrednost cistatina $\mathrm{C}$. 
Između vrednosti klirensa ${ }^{99 \mathrm{~m}} \mathrm{Tc}$-DTPA i recipročnih vrednosti cistatina $\mathrm{C}$ postoji direktna, statistički visoko značajna korelacija $(p<0,001)$.

\subsubsection{Korelacija klirensa ${ }^{99 m}$ Tc-DTPA sa koncentracijama kreatinina i cistatina $C$ u serumu i recipročnim vrednostima cistatina $C$ kod osoba muškog pola}

Da bi se kod bolesnika muškog pola sa BB ustanovila povezanost nivoa klirensa ${ }^{99 m}$ Tc-DTPA sa vrednostima kreatinina u serumu, cistatina $\mathrm{C}$ i recipročne vrednosti cistatina $\mathrm{C}$, određeni su korelacioni koeficijenti (Tabela 6).

Tabela 6. Korelacija klirensa ${ }^{99 m}$ Tc-DTPA i kreatinina i cistatina $\mathrm{C}$ u serumu i recipročnim vrednostima cistatina $\mathrm{C}$ kod bolesnika muškog pola

\begin{tabular}{|c|c|c|c|c|c|}
\hline & & $\begin{array}{c}\text { Kreatinin } \\
\text { u serumu } \\
(\mu \mathrm{mol} / \mathrm{l})\end{array}$ & $\begin{array}{c}\text { Klirens } \\
{ }^{99 m} \text { Tc-DTPA } \\
(\mathrm{ml} / \mathrm{min})\end{array}$ & $\begin{array}{c}\text { Cistatin C } \\
(\mathrm{mg} / \mathrm{l})\end{array}$ & $1 /$ cistatin $C$ \\
\hline \multirow{3}{*}{$\begin{array}{c}\text { Kreatinin } \\
\text { u serumu } \\
(\mu \mathrm{mol} / \mathrm{l})\end{array}$} & $\mathrm{R}$ & 1 & $-0,522(* *)$ & $0,713(* *)$ & $-0,608(* *)$ \\
\hline & Sig. $p$ & & 0,006 & 0,000 & 0,001 \\
\hline & Broj & 26 & 26 & 26 & 26 \\
\hline \multirow{3}{*}{$\begin{array}{c}\text { Klirens } \\
{ }^{99 m} \text { Tc-DTPA } \\
(\mathrm{ml} / \mathrm{min})\end{array}$} & $\mathrm{R}$ & $-0,522(* *)$ & 1 & $-0,415(*)$ & 0,350 \\
\hline & Sig. $p$ & 0,006 & & 0,035 & 0,049 \\
\hline & Broj & 26 & 26 & 26 & 26 \\
\hline \multirow{3}{*}{$\begin{array}{c}\text { Cistatin C } \\
(\mathrm{mg} / \mathrm{l})\end{array}$} & $\mathrm{R}$ & $0,713(* *)$ & $-0,415(*)$ & 1 & $-0,966(* *)$ \\
\hline & Sig. $p$ & 0,000 & 0,035 & & 0,000 \\
\hline & Broj & 26 & 26 & 26 & 26 \\
\hline \multirow{3}{*}{ 1/cistatin C } & $\mathrm{R}$ & $-0,608(* *)$ & 0,350 & $-0,966(* *)$ & 1 \\
\hline & Sig. $p$ & 0,001 & 0,049 & 0,000 & \\
\hline & Broj & 26 & 26 & 26 & 26 \\
\hline
\end{tabular}

** $\mathrm{p}<0,01$ postoji značajna korelacija među parametrima

$* \mathrm{p}<0,05$ postoji značajna korelacija među parametrima

Klirens ${ }^{99 m}$ Tc-DTPA obrnuto statistički značajno korelira sa cistatinom C $(\mathrm{p}<0,035)$, sa porastom klirensa ${ }^{99 \mathrm{~m}}$ Tc-DTPA opada nivo cistatina $\mathrm{C}$ kod muškaraca.

Klirens ${ }^{99 \mathrm{~m}}$ Tc-DTPA direktno, statistički značajno korelira sa recipročnom vrednosti cistatina $\mathrm{C}(\mathrm{p}<0,049)$, sa porastom klirensa ${ }^{99 \mathrm{~m}}$ Tc-DTPA raste visina recipročne vrednosti cistatina $\mathrm{C}$ kod muškaraca.

Klirens ${ }^{99 m}$ Tc-DTPA obrnuto statistički značajno korelira sa kreatininom u serumu, sa porastom kreatinina u serumu značajno najčešće opada nivo klirensa ${ }^{99 \mathrm{~m}} \mathrm{Tc}$ DTPA kod muškaraca $(\mathrm{p}<0,006)$. 
Cistatin C u serumu direktno visoko statistički značajno korelira sa kreatininom, porast cistatin $\mathrm{C}$ u serumu značajno češće prati rast kreatinina kod muškaraca $(\mathrm{p}<0,0001)$.

\subsubsection{Korelacija klirensa ${ }^{99 m}$ Tc-DTPA sa koncentracijama kreatinina i cistatina $C$ u serumu i recipročnim vrednostima cistatina $C$ kod osoba ženskog pola}

Klirens ${ }^{99 \mathrm{~m}}$ Tc-DTPA obrnuto statistički značajno korelira sa kreatininom u serumu kod žena, sa porastom kreatinina u serumu značajno najčešće opada nivo klirensa ${ }^{99 m}$ Tc-DTPA, tako da kad rastu vrednosti kreatinina $u$ serumu značajno najčešće opada klirens ${ }^{99 \mathrm{~m}}$ Tc-DTPA $(\mathrm{p}<0,049)$ (Tabela 7).

Tabela 7. Korelacija klirensa ${ }^{99 \mathrm{~m}}$ Tc-DTPA sa koncentracijama kreatinina i cistatina $\mathrm{C} \mathrm{u}$ serumu i recipročnim vrednostima cistatina $\mathrm{C}$ kod osoba ženskog pola

\begin{tabular}{|c|c|c|c|c|c|}
\hline & & $\begin{array}{c}\text { Kreatinin u } \\
\operatorname{serumu}(\mu \mathrm{mol} / 1)\end{array}$ & $\begin{array}{c}\text { Klirens } \\
{ }^{99} \text { Tc-DTPA } \\
(\mathrm{ml} / \mathrm{min})\end{array}$ & $\begin{array}{c}\text { Cistatin C } \\
(\mathrm{mg} / \mathrm{l})\end{array}$ & 1/cistatin $C$ \\
\hline \multirow{3}{*}{$\begin{array}{l}\text { Kreatinin u serumu } \\
\qquad(\mu \mathrm{mol} / 1)\end{array}$} & $\mathrm{R}$ & 1 & $-0,330(*)$ & $0,527(* *)$ & $-0,518(* *)$ \\
\hline & Sig. $p$ & & 0,049 & 0,001 & 0,001 \\
\hline & Broj & 36 & 36 & 36 & 36 \\
\hline \multirow{3}{*}{$\begin{array}{c}\text { Klirens } \\
{ }^{99 m} \text { Tc-DTPA } \\
(\mathrm{ml} / \mathrm{min})\end{array}$} & $\mathrm{R}$ & $-0,330\left(^{*}\right)$ & 1 & $-0,418\left(^{*}\right)$ & $0,445(* *)$ \\
\hline & Sig. $p$ & 0,049 & & 0,011 & 0,007 \\
\hline & Broj & 36 & 36 & 36 & 36 \\
\hline \multirow{3}{*}{$\begin{array}{c}\text { Cistatin C } \\
(\mathrm{mg} / \mathrm{l})\end{array}$} & $\mathrm{R}$ & $0,527(* *)$ & $-0,418(*)$ & 1 & $-0,952(* *)$ \\
\hline & Sig. $p$ & 0,001 & 0,011 & & 0,000 \\
\hline & Broj & 36 & 36 & 36 & 36 \\
\hline \multirow{3}{*}{ 1/cistatin $C$} & $\mathrm{R}$ & $-0,518(* *)$ & $0,445(* *)$ & $-0,952(* *)$ & 1 \\
\hline & Sig. $p$ & 0,001 & 0,007 & 0,000 & \\
\hline & Broj & 36 & 36 & 36 & 36 \\
\hline
\end{tabular}

** $\mathrm{p}<0,01$ postoji značajna korelacija

$* \mathrm{p}<0,05$ postoji značajna korelacija među parametrima

Klirens ${ }^{99 \mathrm{~m}}$ Tc-DTPA obrnuto, statistički značajno korelira sa cistatinom $\mathrm{C}(\mathrm{p}<0,011)$, sa porastom klirensa ${ }^{99 m}$ Tc-DTPA kod žena opada nivo cistatina C (Tabela 7).

Klirens ${ }^{99 \mathrm{~m}}$ Tc-DTPA je $\mathrm{u}$ direktnoj statistički visoko značajnoj korelaciji sa recipročnom vrednošću cistatina $C(p<0,007)$, sa porastom klirensa ${ }^{99 m}$ Tc-DTPA kod žena raste recipročna vrednost cistatina $\mathrm{C}$. 
Cistatin $\mathrm{C} \mathrm{u}$ serumu direktno statistički visoko značajno korelira sa kreatininom, $(p<0,001)$, i kod žena porast cistatina $\mathrm{C}$ značajno češće prati porast kreatinina u serumu.

\subsubsection{Uticaj životne dobi na vrednosti klirensa ${ }^{99 \mathrm{~m}}$ Tc-DTPA, kreatinina, cistatina $C$ i recipročnu vrednost cistatina $C$}

Da bi se analizirao uticaj životne dobi na nivo klirensa ${ }^{99 \mathrm{~m}}$ Tc-DTPA i na vrednosti kreatinina i cistatina $\mathrm{C}$ u serumu, bolesnici su razvrstani u dobne grupe $\mathrm{i}$ to: do 30 godina, od 30 do 40 godina, od 40 do 50 godina i preko 50 godina.

Tabela 8. Distribucija prosečnih vrednosti kreatinina u odnosu na pripadnost dobnim grupama bolesnika sa BB

\begin{tabular}{|c|c|c|c|c|c|c|c|c|}
\hline & \multirow{2}{*}{ Godine } & \multirow[b]{2}{*}{$\mathrm{N}$} & \multirow{2}{*}{$\begin{array}{l}\text { Srednja } \\
\text { vrednost }\end{array}$} & \multirow[b]{2}{*}{ SD } & \multicolumn{2}{|c|}{$\begin{array}{l}95 \% \text { Interval } \\
\text { pouzdanosti }\end{array}$} & \multirow{2}{*}{ Min. } & \multirow{2}{*}{ Maks. } \\
\hline & & & & & $\begin{array}{l}\text { donja } \\
\text { granica }\end{array}$ & $\begin{array}{l}\text { gornja } \\
\text { granica }\end{array}$ & & \\
\hline \multirow{5}{*}{$\begin{array}{c}\text { Kreatinin } \\
\mu \mathrm{mol} / 1\end{array}$} & do 30 & 7 & 84,43 & 13,54 & 71,91 & 96,95 & 63,00 & 97,00 \\
\hline & $30-40$ & 10 & 83,00 & 12,10 & 67,97 & 98,03 & 69,00 & 97,00 \\
\hline & $40-50$ & 22 & 87,63 & 25,27 & 74,16 & 101,09 & 49,00 & 128,00 \\
\hline & $>50$ & 23 & 91,47 & 26,82 & 76,62 & 106,32 & 69,00 & 169,00 \\
\hline & ukupno & 62 & 87,91 & 22,74 & 80,91 & 94,91 & 49,00 & 169,00 \\
\hline
\end{tabular}

Prosečna koncentracija kreatinina u serumu je rasla sa starošću bolesnika i najviša je bila kod bolesnika starijih od 50 godina, ali nije dokazana statistički značajna razlika $\mathrm{u}$ nivou kreatinina u odnosu na starosnu dob bolesnika $(\mathrm{F}=0,242 \mathrm{p}=\mathrm{ns})$ (Tabela 8 , Slika $11)$. 


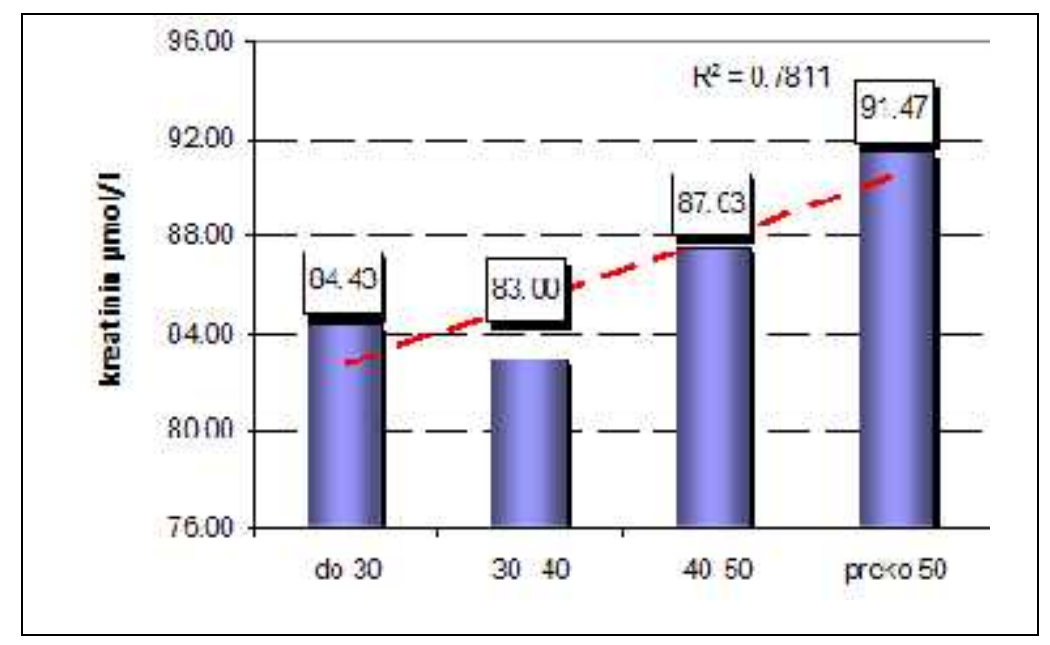

Slika 11. Koncentracija kreatinina u serumu u odnosu na starosnu dob bolesnika

Prosečni nivo klirensa ${ }^{99 m}$ Tc-DTPA je opadao sa starošću bolesnika (u grupi od 30-40 godina bila je najviša vrednost) i najniža vrednost je bila kod bolesnika starijih od 50 godina, tako da je dokazana statistički značajna razlika u vrednosti klirensa ${ }^{99 \mathrm{~m}} \mathrm{Tc}$ DTPA u odnosu na starosnu dob bolesnika $(\mathrm{F}=3,418 \mathrm{p}<0,02)$ (Tabela 9, Slika 12).

Tabela 9. Distribucija prosečnih vrednosti klirensa ${ }^{99 \mathrm{~m}}$ Tc-DTPA u odnosu na pripadnost dobnim grupama bolesnika sa BB

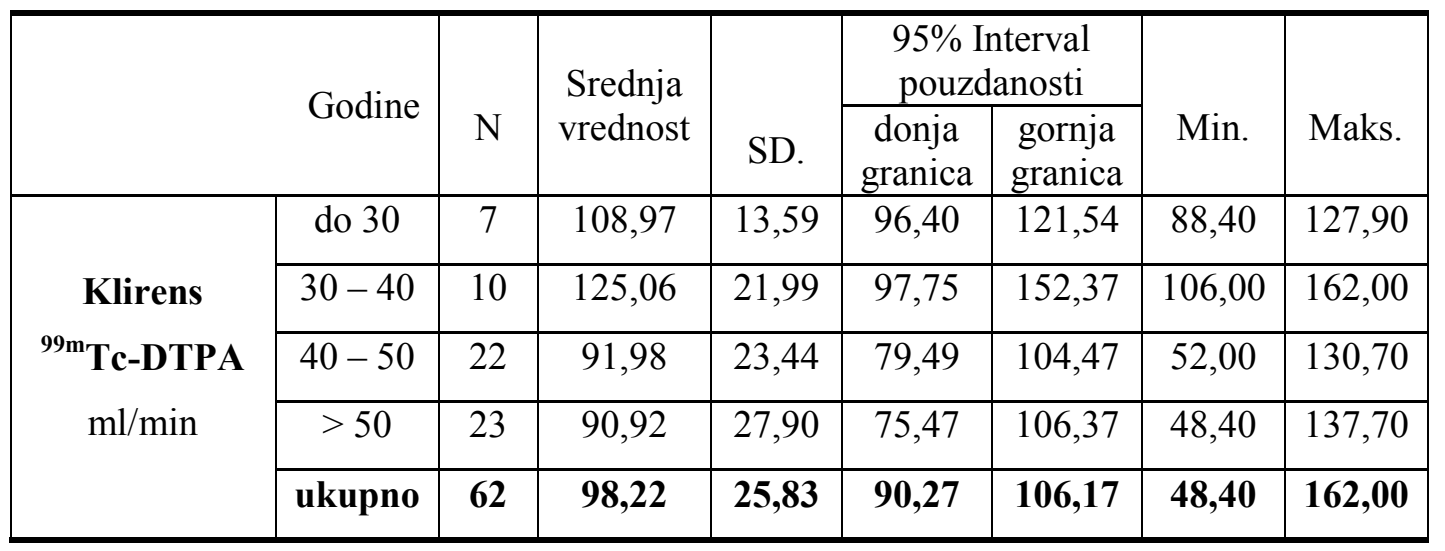




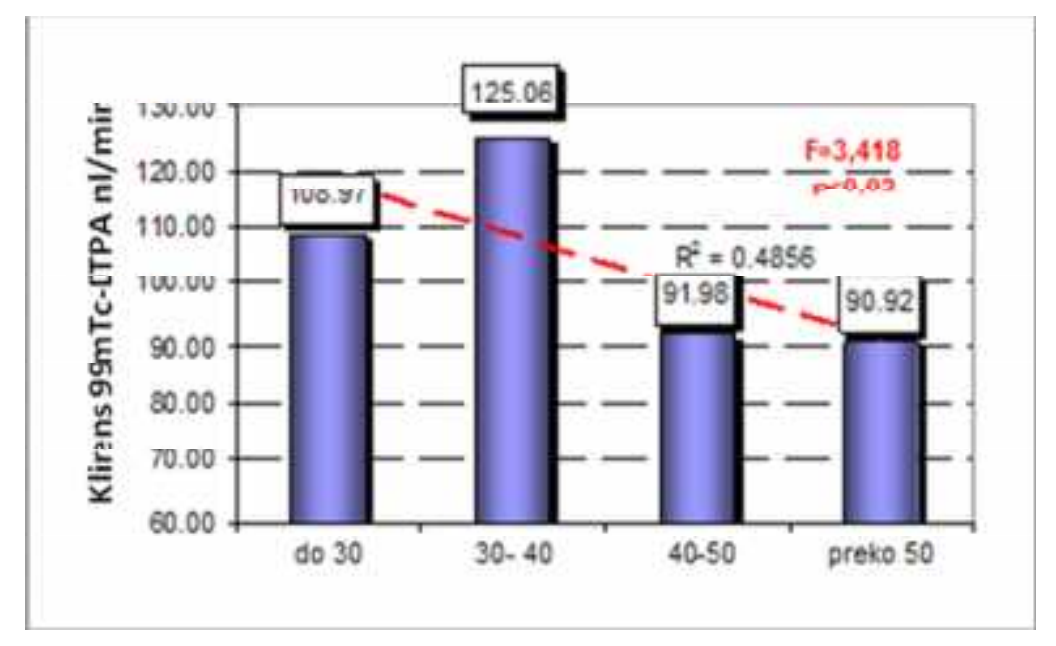

Slika 12. Vrednosti klirensa ${ }^{99 \mathrm{~m}}$ Tc-DTPA u odnosu na starosnu dob bolesnika

Prosečna koncentracija cistatina $\mathrm{C}$ raste sa starošću bolesnika i najviša vrednost je bila kod bolesnika starijih od 50 godina, ali bez statistički značajne razlike između vrednosti cistatina $\mathrm{C}$ u odnosu na starosnu dob bolesnika $(\mathrm{F}=1,237 \mathrm{p}=\mathrm{ns})$ (Tabela 10, Slika 13).

Tabela 10. Distribucija prosečnih vrednosti cistatina $\mathrm{C}$ u odnosu na pripadnost dobnim grupama bolesnika sa BB

\begin{tabular}{|c|c|c|c|c|c|c|c|c|}
\hline & & \multirow[t]{2}{*}{$\mathrm{N}$} & \multirow{2}{*}{$\begin{array}{l}\text { Srednja } \\
\text { vrednost }\end{array}$} & \multirow[b]{2}{*}{$\mathrm{SD}$} & \multicolumn{2}{|c|}{$\begin{array}{c}95 \% \\
\text { granica } \\
\text { pouzdanosti }\end{array}$} & \multirow[t]{2}{*}{ Min. } & \multirow[t]{2}{*}{ Maks. } \\
\hline & & & & & $\begin{array}{c}\text { Donja } \\
\text { granica }\end{array}$ & $\begin{array}{l}\text { Gornja } \\
\text { granica }\end{array}$ & & \\
\hline \multirow{5}{*}{$\begin{array}{c}\text { Cistatin C } \\
(\mathrm{mg} / \mathrm{l})\end{array}$} & do 30 & 7 & 0,77 & 0,10 & 0,68 & 0,87 & 0,64 & 0,89 \\
\hline & $30-40$ & 10 & 0,77 & 0,21 & 0,51 & 1,03 & 0,56 & 1,07 \\
\hline & $40-50$ & 22 & 0,88 & 0,24 & 0,75 & 1,00 & 0,48 & 1,31 \\
\hline & $>50$ & 23 & 0,94 & 0,24 & 0,80 & 1,07 & 0,66 & 1,61 \\
\hline & ukupno & 62 & 0,87 & 0,22 & $\mathbf{0 , 8 0}$ & 0,94 & 0,48 & 1,61 \\
\hline
\end{tabular}




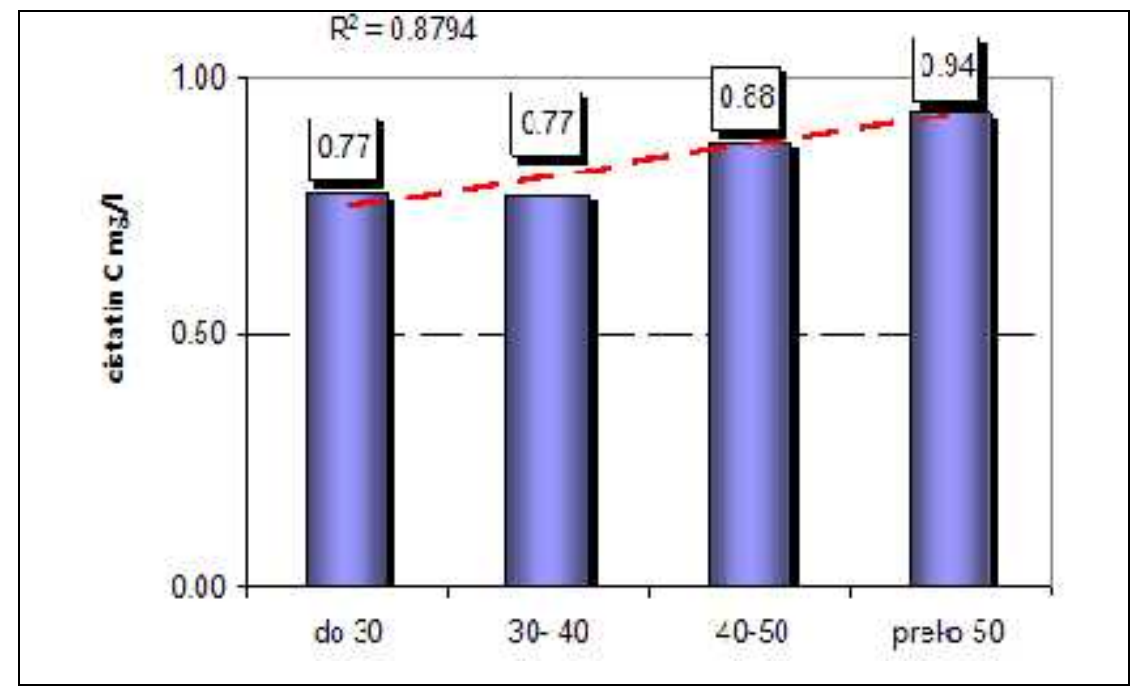

Slika 13. Koncentracija cistatina $\mathrm{C}$ u odnosu na starosnu dob bolesnika

Najniža prosečna recipročna vrednost cistatina $\mathrm{C}$ je bila kod bolesnika starijih od 50 godina a najviša kod bolesnika starosti između 30 i 40 godina. Nije bilo statistički značajne razlike u nivou recipročne vrednosti cistatina $\mathrm{C}$ u odnosu na starosnu dob bolesnika $(\mathrm{F}=1,341 \mathrm{p}=\mathrm{ns})($ Tabela 11$)$.

Tabela 11. Distribucija prosečnih recipročnih vrednosti cistatina $\mathrm{C}$ u odnosu na pripadnost dobnim grupama bolesnika sa BB

\begin{tabular}{|c|c|c|c|c|c|c|c|c|}
\hline \multirow[t]{3}{*}{ 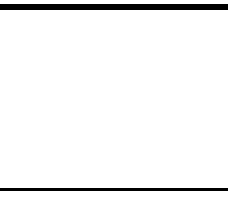 } & \multirow[t]{2}{*}{ Godine } & \multirow{2}{*}{$\mathrm{N}$} & \multirow{2}{*}{$\begin{array}{l}\text { Srednja } \\
\text { vrednost }\end{array}$} & \multirow[b]{2}{*}{$\mathrm{SD}$} & \multicolumn{2}{|c|}{$\begin{array}{l}95 \% \text { Granica } \\
\text { pouzdanosti }\end{array}$} & \multirow{2}{*}{ Min. } & \multirow{2}{*}{ Maks. } \\
\hline & & & & & $\begin{array}{l}\text { Donja } \\
\text { granica }\end{array}$ & $\begin{array}{l}\text { Gornja } \\
\text { granica }\end{array}$ & & \\
\hline & do 30 & 7 & 1,31 & 0,19 & 1,14 & 1,48 & 1,12 & 1,56 \\
\hline \multirow{4}{*}{$1 /$ cistatin $C$} & $30-40$ & 10 & 1,37 & 0,34 & 0,95 & 1,80 & 0,93 & 1,79 \\
\hline & $40-50$ & 22 & 1,23 & 0,36 & 1,04 & 1,42 & 0,76 & 2,08 \\
\hline & $>50$ & 23 & 1,12 & 0,23 & 0,99 & 1,25 & 0,62 & 1,52 \\
\hline & ukupno & 62 & 1,22 & 0,30 & 1,13 & 1,31 & 0,62 & 2,08 \\
\hline
\end{tabular}




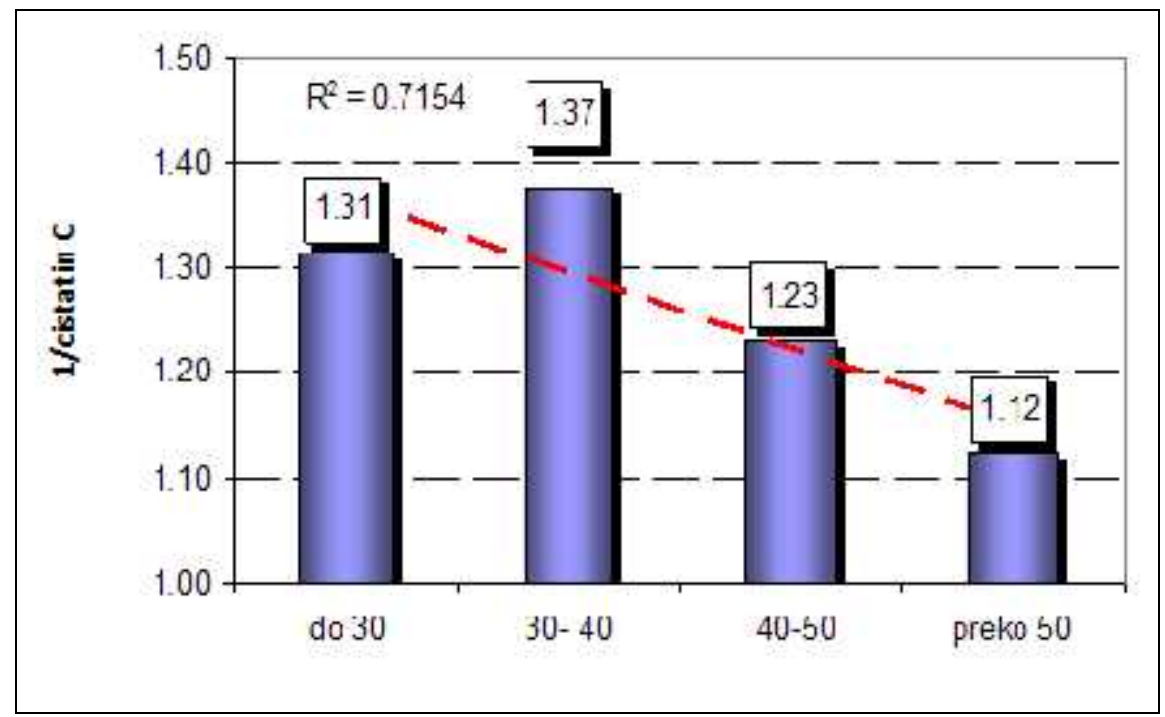

Slika 14. Recipročne vrednosti cistatina $\mathrm{C}$ u odnosu na starosnu dob bolesnika

Prosečne recipročne vrednosti cistatina $\mathrm{C}$ imale su opadajući trend $\mathrm{u}$ odnosu na starost bolesnika (Slika 14). 


\subsection{REZULTATI ODREĐIVANJA KREATININA, KLIRENSA KREATININA I CISTATINA C KOD TRUDNICA}

Za procenu JGF u poslednjoj dekadi nametnuo se kao alternativa skupim, zahtevnim i nedovoljno pouzdanim tehnikama cistatin C. Jedan od ciljeva ovog rada bio je da utvrdi da li cistatin C može u trudnoći da bude dobar pokazatelj JGF. Grupi od 109 trudnica različite gestacione dobi određen je nivo cistatina $\mathrm{C}$ i kreatinina u serumu i klirens kreatinina.

\subsubsection{Distribucija trudnica prema gestacionom periodu}

Trudnice su prema gestacionom periodu razvrstane $u$ tri trimestra.

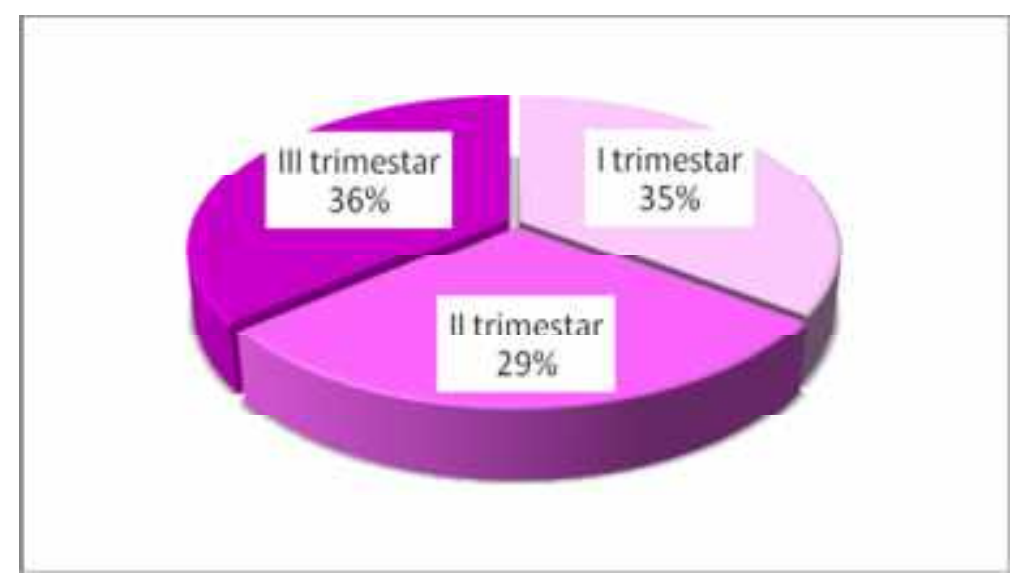

Slika 15. Distribucija trudnica prema trimestrima

U prvom trimestru trudnoće bilo je 38 (35\%) trudnica, u drugom trimestru 32 (29\%) i u trećem trimestru trudnoće bilo je 39 (36\%) trudnica (Slika 15).

Prosečna starost ispitivanih trudnica iznosila je 31,39 $\pm 5,65$ godina. Najmlađa trudnica imala je 20 godina, a najstarija 45 godina. Raspon starosti bio je veći od 20 godina.

Prosečna starost trudnica u prvom trimestru iznosila je 29,63 \pm 4,3 godina, najmlađa je imala je 22 godina, a najstarija 36 godinam (Tabela 12). 
Prosečna starost trudnica drugog trimestra bila je 33,56 \pm 5,95 godina, najmlađa je imala 21 godinu a najstarija 41 godinu. Prosečna starost trudnica u trećem trimestru bila je 31,31 \pm 6,07 godina, najmlađa je imala 20 godina, a najstarija 45 godina (Slika 16).

Tabela 12. Prosečna starost trudnica po trimestrima

\begin{tabular}{|l|c|c|c|c|c|c|c|}
\hline \multicolumn{3}{|c|}{} & \multicolumn{2}{|c|}{$95 \%$ Granica pouzdanosti } & \multicolumn{2}{|c|}{} \\
\hline $\begin{array}{l}\text { gestacioni } \\
\text { period }\end{array}$ & $\mathrm{N}$ & $\begin{array}{c}\text { Prosečna } \\
\text { starost } \\
\text { (godine) }\end{array}$ & $\mathrm{SD}$ & $\begin{array}{c}\text { donja } \\
\text { granica }\end{array}$ & $\begin{array}{c}\text { gornja } \\
\text { granica }\end{array}$ & Min. & Maks. \\
\hline I trimestar & 38 & 29,63 & 4,30 & 28,22 & 31,05 & 22 & 36 \\
\hline II trimestar & 32 & 33,56 & 5,95 & 31,42 & 35,71 & 21 & 41 \\
\hline III trimestar & 39 & 31,31 & 6,07 & 29,34 & 33,28 & 20 & 45 \\
\hline ukupno & $\mathbf{1 0 9}$ & $\mathbf{3 1 , 3 9}$ & $\mathbf{5 , 6 5}$ & $\mathbf{3 0 , 3 1}$ & $\mathbf{3 2 , 4 6}$ & $\mathbf{2 0}$ & $\mathbf{4 5}$ \\
\hline
\end{tabular}

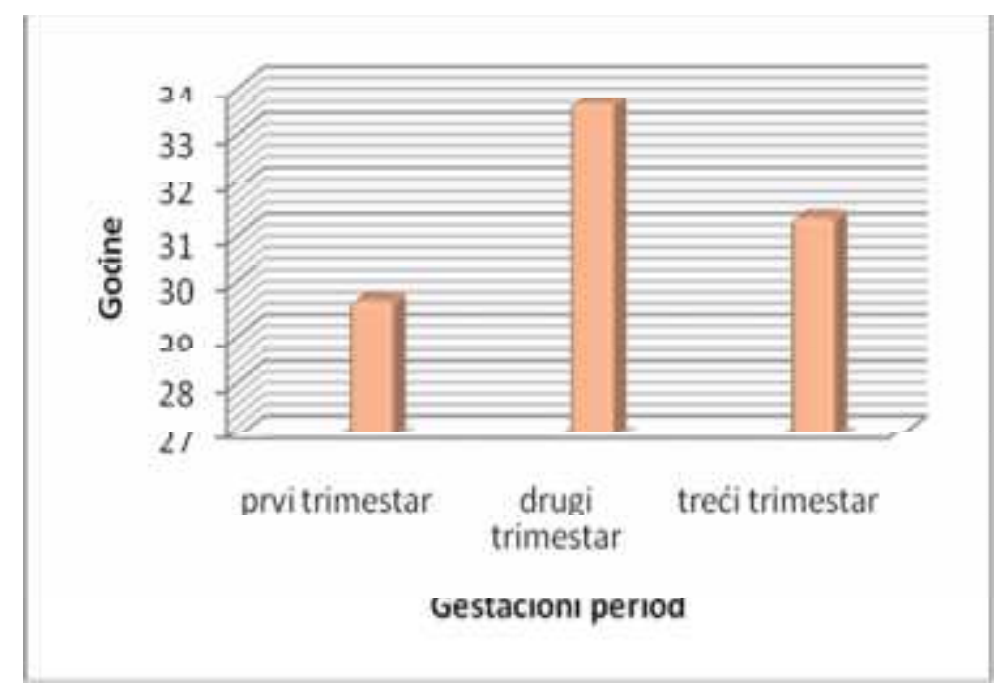

Slika 16. Prosečna starost trudnica po trimestrima

Primenom ANOVA testa ispitano je da li postoji statistički značajna razlika u starosnoj dobi trudnica u zavisnosti od trimestra kome su pripadale.

Trudnice $u$ prvom trimestru bile su statistički značajno mlađe od trudnica $u$ drugom trimestru, dok nije bilo statistički značajne razlike u starosti trudnica trećeg trimestra prema trudnicama prvog i drugog trimestra (Tabela 13). 
Tabela 13. Korelacija starosne dobi prema trimestrima

\begin{tabular}{|l|l|c|c|c|c|c|}
\hline \multirow{2}{*}{$\begin{array}{l}\text { Gestacioni } \\
\text { period }\end{array}$} & \multicolumn{4}{|c|}{} & \multicolumn{2}{c|}{$95 \%$ Granica pouzdanosti } \\
\cline { 2 - 7 } & & $\begin{array}{c}\text { Srednja razlika } \\
\text { među grupama }\end{array}$ & SE & $*$ p & $\begin{array}{c}\text { donja } \\
\text { granica }\end{array}$ & $\begin{array}{c}\text { gornja } \\
\text { granica }\end{array}$ \\
\hline I trimestar & II trimestar & $-3,93$ & 1,31 & 0,00 & $-6,54$ & $-1,32$ \\
& III trimestar & $-1,68$ & 1,25 & 0,18 & $-4,15$ & 0,80 \\
\hline II trimestar & I trimestar & 3,93 & 1,31 & 0,00 & 1,32 & 6,54 \\
& III trimestar & 2,25 & 1,31 & 0,09 & $-0,34$ & 4,85 \\
\hline III trimestar & I trimestar & 1,68 & 1,25 & 0,18 & $-0,80$ & 4,15 \\
& II trimestar & $-2,25$ & 1,31 & 0,09 & $-4,85$ & 0,34 \\
\hline
\end{tabular}

*p $<0,05$ postoji značajna korelacija među trimestrima

\subsubsection{Distribucija vrednosti kreatinina, klirensa kreatinina, cistatina $\mathrm{C}$ i recipročne vrednosti cistatina $\mathrm{C}$ kod trudnica različite gestacione dobi}

Da bi se ispitala mogućnost primene cistatina C kao markera JGF svim trudnicama je određivan nivo cistatina $C$, kreatinina i klirensa kreatinina. Prosečna vrednost kreatinina u serumu kod trudnica obuhvaćenih istraživanjem kretala se $\mathrm{u}$ opsegu referentnih vrednosti i iznosila je 63,50 \pm 10,07 $\mu \mathrm{mol} / 1$ (Tabela 14).

Tabela 14. Prosečne vrednosti kreatinina u serumu prema trimestrima

\begin{tabular}{|c|c|c|c|c|c|c|c|c|}
\hline & \multirow{2}{*}{$\mathrm{N}$} & \multirow{2}{*}{ Prosek } & \multirow{2}{*}{ SD } & \multicolumn{2}{|c|}{$\begin{array}{c}95 \% \text { Granica } \\
\text { pouzdanosti }\end{array}$} & \multirow{2}{*}{ Min. } & \multirow{2}{*}{ Maks } \\
\hline & & & & & $\begin{array}{l}\text { donja } \\
\text { granica }\end{array}$ & $\begin{array}{l}\text { gornja } \\
\text { granica }\end{array}$ & & \\
\hline \multirow{4}{*}{$\begin{array}{c}\text { Kreatinin } \\
\text { u serumu } \\
(\mu \mathrm{mol} / \mathrm{l})\end{array}$} & I trimestar & 38 & 59,11 & 6,71 & 56,90 & 61,31 & 50 & 75 \\
\hline & $\begin{array}{l}\text { II } \\
\text { trimestar }\end{array}$ & 32 & 66,03 & 12,32 & 61,59 & 70,47 & 45 & 84 \\
\hline & $\begin{array}{l}\text { III } \\
\text { trimestar }\end{array}$ & 39 & 65,69 & 9,54 & 62,60 & 68,78 & 49 & 87 \\
\hline & ukupno & 109 & 63,50 & 10,07 & 61,58 & 65,41 & 45 & 87 \\
\hline
\end{tabular}




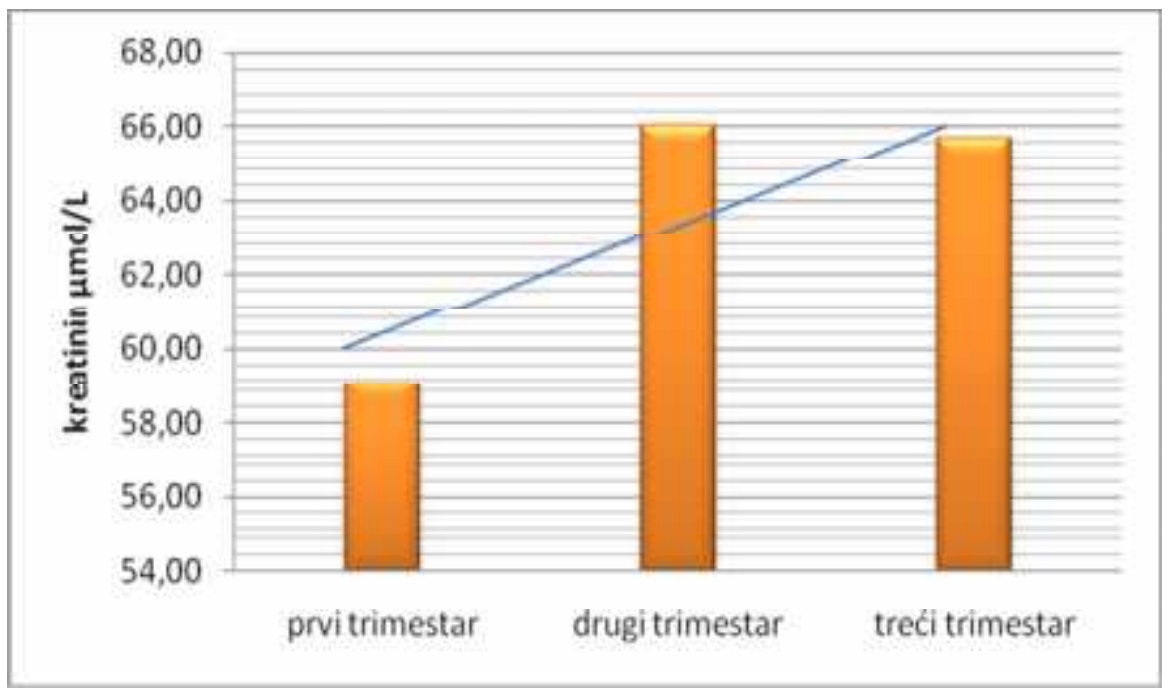

Slika 17. Prosečna vrednost kreatinina u serumu prema trimestrima

Potom su prosečne vrednosti kreatinina u serumu trudnica razvrstane $u$ odnosu na gestacioni period. Prosečna vrednost kreatinina u serumu kod trudnica u prvom trimestru iznosila je $59,11 \pm 6,71 \mu \mathrm{mol} / 1$, dok je prosečna vrednost kreatinina u serumu kod trudnica $\mathrm{u}$ drugom trimestru bila $66,03 \pm 12,32 \mu \mathrm{mol} / 1$. Prosečna koncentracija kreatinina u serumu kod trudnica u trećem trimestru iznosila je 65,69 \pm 9,54 $\mu \mathrm{mol} / \mathrm{l}$, (Slika 17).

Prosečna vrednost klirensa kreatinina kod trudnica obuhvaćenih istraživanjem iznosila je 107,11 $19,91 \mathrm{ml} / \mathrm{min}$. Najniža vrednost klirensa kreatinina iznosila je 63 ml/min, a najviša vrednost klirensa kreatinina iznosila je 169,20 ml/min (Tabela 15).

Tabela 15. Prosečne vrednosti klirensa kreatinina prema trimestrima

\begin{tabular}{|c|c|c|c|c|c|c|c|c|}
\hline & \multirow{2}{*}{$\mathrm{N}$} & \multirow{2}{*}{ Prosek } & \multirow{2}{*}{ SD } & \multicolumn{2}{|c|}{$\begin{array}{l}95 \% \text { Granica } \\
\text { pouzdanosti }\end{array}$} & \multirow{2}{*}{ Min. } & \multirow{2}{*}{ Maks. } \\
\hline & & & & & $\begin{array}{l}\text { Donja } \\
\text { granica }\end{array}$ & $\begin{array}{l}\text { Gornja } \\
\text { granica }\end{array}$ & & \\
\hline \multirow{4}{*}{$\begin{array}{c}\text { Klirens } \\
\text { kreatinina } \\
(\mathrm{ml} / \mathrm{min})\end{array}$} & I trimestar & 38 & 106,61 & 15,69 & 101,45 & 111,77 & 79,80 & 150,60 \\
\hline & II trimestar & 32 & 106,99 & 24,50 & 98,15 & 115,82 & 63,00 & 169,20 \\
\hline & III trimestar & 39 & 107,69 & 19,91 & 101,24 & 114,15 & 64,20 & 159,00 \\
\hline & ukupno & 109 & 107,11 & 19,91 & 103,33 & 110,89 & 63,00 & 169,20 \\
\hline
\end{tabular}




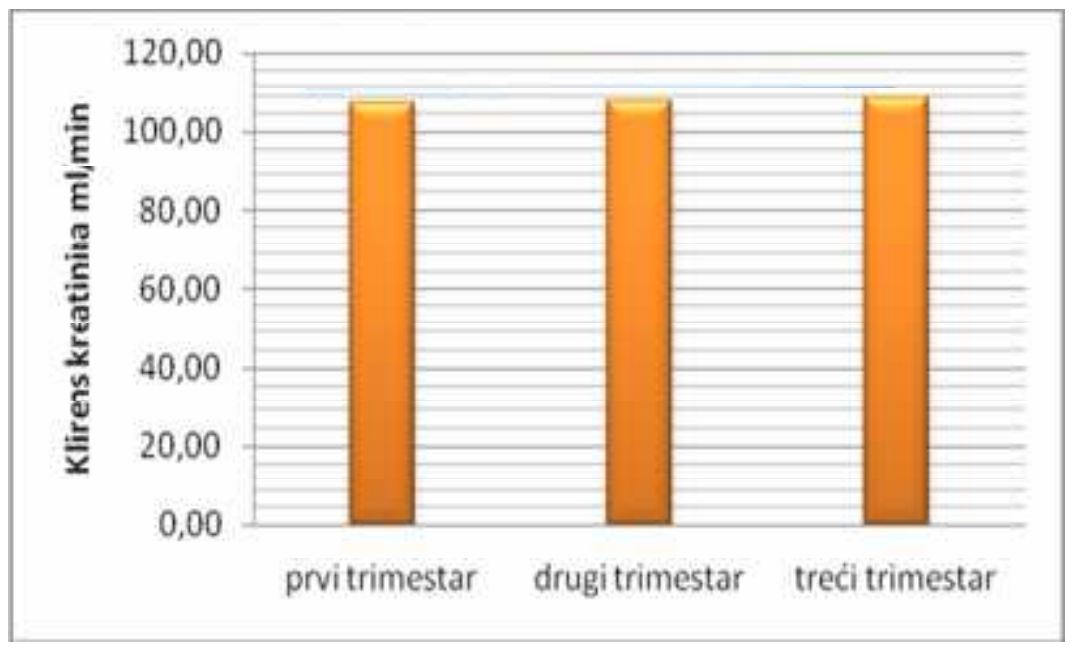

Slika 18. Prosečna vrednost klirensa kreatinina zavisno od trimestra

U prvom trimestru trudnoće trudnice su imale prosečnu vrednost klirensa kreatinina 106,61 $\mathrm{ml} / \mathrm{min}$ sa standardnom devijacijom od $\pm 15,69 \mathrm{ml} / \mathrm{min}$. Najniža vrednost klirensa kreatinina u ovom trimestru iznosila je $79,8 \mathrm{ml} / \mathrm{min}$, a najviša 150,6 $\mathrm{ml} / \mathrm{min}$.

Prosečna vrednost klirensa kreatinina kod trudnica u drugom trimestru iznosila je $106,99 \pm 24,50 \mathrm{ml} / \mathrm{min}$ sa rasponom vrednosti u opsegu od $63 \mathrm{ml} / \mathrm{min}$ do 169,20 $\mathrm{ml} / \mathrm{min}$.

Prosečni nivo klirensa kreatinina kod trudnica u trećem trimestru bio je 107,69 \pm $19,91 \mathrm{ml} / \mathrm{min}$ sa rasponom vrednosti od $64,2 \mathrm{ml} / \mathrm{min}$ do $159,0 \mathrm{ml} / \mathrm{min}$ (Slika 18).

Prosečna vrednost cistatina $\mathrm{C}$ kod trudnica obuhvaćenih istraživanjem iznosila je $0,90 \pm 0,34 \mathrm{mg} / \mathrm{l}$. Najniža vrednost cistatina $\mathrm{C}$ iznosila je $0,35 \mathrm{mg} / \mathrm{l}$ dok je najviša vrednost cistatina C bila 1,93 mg/l (Tabela 16 ).

Tabela 16. Prosečne vrednosti cistatina $\mathrm{C}$ u serumu prema trimestrima

\begin{tabular}{|c|c|c|c|c|c|c|c|c|}
\hline & \multirow{2}{*}{$\mathrm{N}$} & \multirow{2}{*}{ Prosek } & \multirow{2}{*}{ SD } & \multicolumn{2}{|c|}{$\begin{array}{l}95 \% \text { Granica } \\
\text { pouzdanosti }\end{array}$} & \multirow[b]{2}{*}{ Min. } & \multirow[b]{2}{*}{ Maks } \\
\hline & & & & & $\begin{array}{l}\text { Donja } \\
\text { granica }\end{array}$ & $\begin{array}{l}\text { gornja } \\
\text { granica }\end{array}$ & & \\
\hline \multirow{4}{*}{$\begin{array}{c}\text { Cistatin C } \\
(\mathrm{mg} / \mathrm{l})\end{array}$} & I trimestar & 38 & 0,69 & 0,16 & 0,64 & 0,74 & 0,35 & 0,98 \\
\hline & II trimestar & 32 & 0,78 & 0,26 & 0,69 & 0,87 & 0,54 & 1,74 \\
\hline & III trimestar & 39 & 1,21 & 0,30 & 1,11 & 1,31 & 0,73 & 1,93 \\
\hline & ukupno & 109 & $\mathbf{0 , 9 0}$ & $\mathbf{0 , 3 4}$ & $\mathbf{0 , 8 4}$ & $\mathbf{0 , 9 7}$ & $\mathbf{0 , 3 5}$ & 1,93 \\
\hline
\end{tabular}




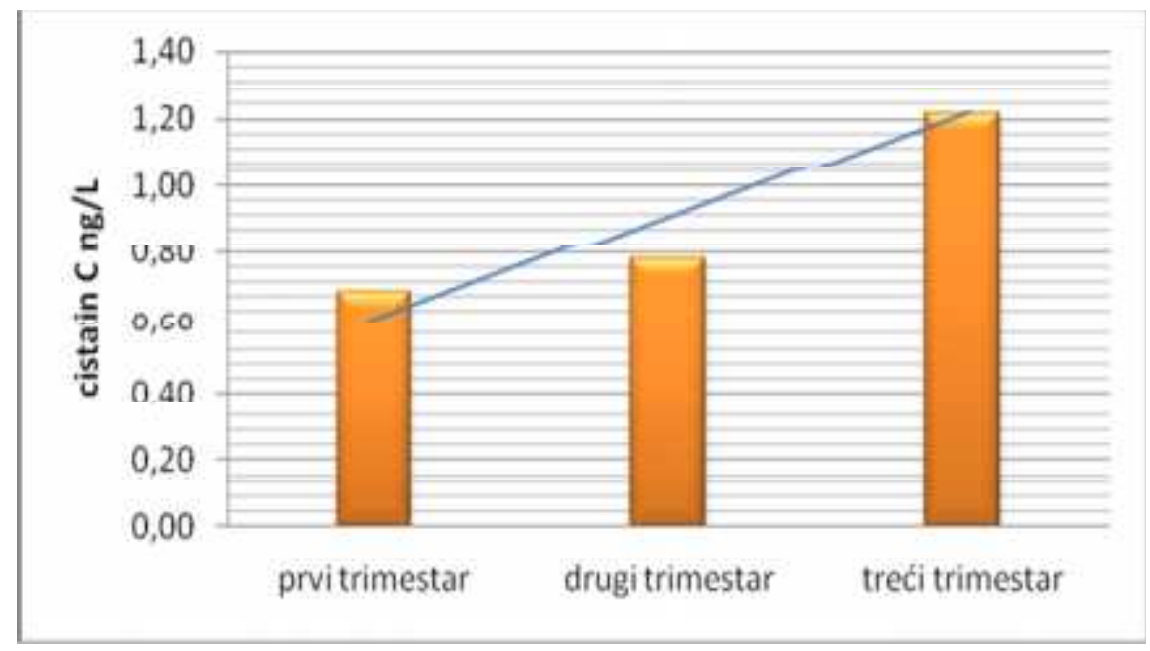

Slika 19. Prosečna vrednost cistatina $C$ zavisno od trimestra

Trudnice u prvom trimestru su imale prosečnu vrednost cistatina $C$ C,69 mg/l sa standardnom devijacijom $\pm 0,16 \mathrm{mg} / \mathrm{l}$. Vrednosti cistatina $\mathrm{C}$ u prvom trimestru su se kretale u rasponu od $0,35 \mathrm{mg} / \mathrm{l}$ do $0,98 \mathrm{mg} / \mathrm{l}$.

Prosečna vrednost cistatina $\mathrm{C}$ kod trudnica $\mathrm{u}$ drugom trimestru bila je $0,78 \pm 0,26$ $\mathrm{mg} / \mathrm{l}$. Najniža vrednost cistatina $\mathrm{C}$ kod trudnica u drugom trimestru iznosila je 0,54 $\mathrm{mg} / \mathrm{l}$, a najviša vrednost cistatina $\mathrm{C}$ iznosila je $1,74 \mathrm{mg} / \mathrm{l}$.

Prosečna vrednost cistatina $\mathrm{C}$ kod trudnica u trećem trimestru bila je 1,21 $\pm 0,30$ $\mathrm{mg} / \mathrm{l}$ a vrednosti su se kretale u rasponu od $0,73 \mathrm{mg} / 1$ do $1,93 \mathrm{mg} / 1$ (Slika 19).

Tabela 17. Prosečna vrednost $1 /$ cistatin $C$ zavisno od trimestra

\begin{tabular}{|c|c|c|c|c|c|c|c|c|}
\hline & \multirow{2}{*}{$\mathrm{N}$} & \multirow{2}{*}{$\begin{array}{l}\text { Prose } \\
\mathrm{k}\end{array}$} & \multirow{2}{*}{$\mathrm{SD}$} & \multicolumn{2}{|c|}{$\begin{array}{r}95 \% \text { Granica } \\
\text { pouzdanosti }\end{array}$} & \multirow{2}{*}{ Min. } & \multirow{2}{*}{ Maks. } \\
\hline & & & & & $\begin{array}{c}\text { Donja } \\
\text { granica }\end{array}$ & $\begin{array}{l}\text { Gornja } \\
\text { granica }\end{array}$ & & \\
\hline \multirow{4}{*}{ 1/cistatin C } & I trimestar & 38 & 1,53 & 0,41 & 1,40 & 1,67 & 1,02 & 2,86 \\
\hline & II trimestar & 32 & 1,37 & 0,30 & 1,26 & 1,49 & 0,57 & 1,85 \\
\hline & III trimestar & 39 & 0,87 & 0,21 & 0,80 & 0,94 & 0,52 & 1,37 \\
\hline & Ukupno & 109 & 1,25 & 0,43 & 1,17 & 1,33 & $\mathbf{0 , 5 2}$ & 2,86 \\
\hline
\end{tabular}




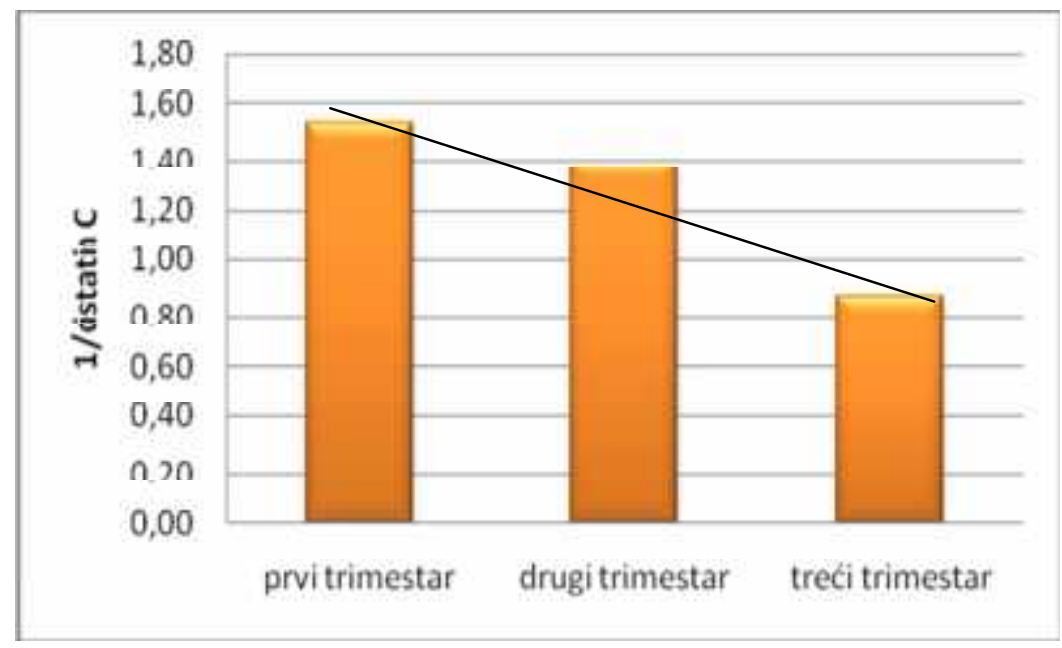

Slika 20. Prosečna vrednost $1 /$ cistatin $C$ zavisno od trimestra

Srednja recipročna vrednost cistatina $\mathrm{C}$ kod trudnica obuhvaćenih istraživanjem iznosila je $1,25 \pm 0,43$. Najniža recipročna vrednost cistatina $C$ iznosila je 0,52 dok je najviša bila 2,86 (Tabela 17 ).

Trudnice u prvom trimestru imale su srednju recipročnu vrednost cistatina $\mathrm{C}$ 1,53 $\pm 0,41$, dok je u drugom trimestru bila $1,37 \pm 0,30$. Srednja recipročna vrednost cistatina $\mathrm{C}$ u trećem trimestru je bila $0,87+0,21$ (Slika 20).

\subsubsection{Korelacija gestacionog doba trudnica sa vrednostima kreatinina, klirensa kreatinina, cistatina $C$ i recipročnim vrednostima cistatina $C$}

Rezultati korelacionih analiza kreatinina, klirensa kreatinina, cistatina $\mathrm{C}$ i recipročne vrednosti cistatina $\mathrm{C}$ u sva tri trimestra trudnoće prikazani su tabelarno.

Analizom varijanse (ANOVA) prosečnih vrednosti kreatinina utvrdili smo da su kod trudnica statistički značajno bile različite vrednosti kreatinina u odnosu na trimestre trudnoće $(\mathrm{F}=6,078 \mathrm{p}<0,003)$.

Dodatno je primenjena i višestruka komparacija LSD testa koji je pokazao da su statistički značajno niže vrednosti kreatinina u serumu u prvom trimestru u odnosu na drugi i treći trimestar $(\mathrm{p}=0,003)$ ali da nema statistički značajne razlike $u$ vrednosti kreatinina u drugom trimestru u odnosu na treći trimestar $(\mathrm{p}=0,883)$ (Tabela 18). 
Tabela 18. LSD testiranje među trimestrima prosečnih vrednosti kreatininina u serumu

\begin{tabular}{|c|c|c|c|c|c|c|}
\hline \multicolumn{7}{|c|}{ Kreatinin $\mu \mathrm{mol} / \mathrm{l}$} \\
\hline \multirow[b]{2}{*}{ Grupe } & \multirow[b]{2}{*}{ Grupe } & \multirow{2}{*}{$\begin{array}{c}\text { Srednja } \\
\text { razlika među } \\
\text { grupama }\end{array}$} & \multirow[b]{2}{*}{ SE } & \multirow[b]{2}{*}{ Sig. } & \multicolumn{2}{|c|}{$\begin{array}{l}\text { 95\% Granica } \\
\text { pouzdanosti }\end{array}$} \\
\hline & & & & & $\begin{array}{l}\text { Donja } \\
\text { granica }\end{array}$ & $\begin{array}{l}\text { Gornja } \\
\text { granica }\end{array}$ \\
\hline I trimestar & $\begin{array}{l}\text { II trimestar } \\
\text { III trimestar }\end{array}$ & $\begin{array}{l}-6,926 \\
-6,587 \\
\end{array}$ & $\begin{array}{l}2,310 \\
2,194\end{array}$ & $\begin{array}{l}0,003 \\
0,003\end{array}$ & $\begin{array}{l}-11,51 \\
-10,94 \\
\end{array}$ & $\begin{array}{l}-2,35 \\
-2,24 \\
\end{array}$ \\
\hline II trimestar & $\begin{array}{l}\text { I trimestar } \\
\text { III trimestar }\end{array}$ & $\begin{array}{l}6,926 \\
0,339 \\
\end{array}$ & $\begin{array}{l}2,310 \\
2,296 \\
\end{array}$ & $\begin{array}{l}0,003 \\
0,883 \\
\end{array}$ & $\begin{array}{r}2,35 \\
-4,21 \\
\end{array}$ & $\begin{array}{c}11,51 \\
4,89 \\
\end{array}$ \\
\hline III trimestar & $\begin{array}{l}\text { I trimestar } \\
\text { II trimestar }\end{array}$ & $\begin{array}{r}6,587 \\
-0,339\end{array}$ & $\begin{array}{l}2,194 \\
2,296\end{array}$ & $\begin{array}{l}0,003 \\
0,883\end{array}$ & $\begin{array}{c}2,24 \\
-4,89\end{array}$ & $\begin{array}{c}10,94 \\
4,21\end{array}$ \\
\hline
\end{tabular}

Analiza varijanse prosečnih vrednosti klirensa kreatinina (ANOVA) je pokazala da se klirens kreatinina ne menja statistički značajno zavisno od trimestra $(\mathrm{F}=0,029$ $\mathrm{p}=0,972$ ). Dodatno je primenjeno LSD testiranje - višestruka komparacija, koje je pokazalo da na klirens kreatinina ne utiče gestaciona dob (Tabela 19).

Tabela 19. LSD testiranje među trimestrima prosečnih vrednosti klirensa kreatininina

\begin{tabular}{|l|l|c|c|c|c|c|}
\hline \multicolumn{9}{|c|}{ Klirens kreatinina ml/min } \\
\hline \multirow{2}{*}{ Grupe } & $\begin{array}{c}\text { Srednja } \\
\text { razlika među } \\
\text { grupama }\end{array}$ & SE & Sig. & $\begin{array}{c}\text { 95\% Granica } \\
\text { pouzdanosti }\end{array}$ \\
\cline { 5 - 8 } & Granja & $\begin{array}{c}\text { Gornja } \\
\text { granica }\end{array}$ \\
\hline I trimestar & II trimestar & $-0,37697$ & 4,82022 & 0,938 & $-9,9335$ & 9,1796 \\
\hline & III trimestar & $-1,08178$ & 4,57937 & 0,814 & $-10,1608$ & 7,9973 \\
\hline II trimestar & I trimestar & 0,37697 & 4,82022 & 0,938 & $-9,1796$ & 9,9335 \\
\hline & III trimestar & $-0,70481$ & 4,79189 & 0,883 & $-10,2052$ & 8,7956 \\
\hline III trimestar & I trimestar & 1,08178 & 4,57937 & 0,814 & $-7,9973$ & 10,1608 \\
\hline & III trimestar & 0,70481 & 4,79189 & 0,883 & $-8,7956$ & 10,2052 \\
\hline
\end{tabular}

Rezultati ANOVA testa prosečnih vrednosti cistatina C pokazuju da se vrednosti cistatina $\mathrm{C}$ visoko statistički značajno razlikuju po trimestrima $(F=48,64 \mathrm{p}<0,0001)$. 
Tabela 20. LSD testiranje među trimestrima prosečnih vrednosti cistatina $\mathrm{C}$ u serumu

\begin{tabular}{|c|c|c|c|c|c|c|}
\hline \multicolumn{7}{|c|}{ Cistatin C mg/l } \\
\hline \multirow[b]{2}{*}{ Grupe } & \multirow[b]{2}{*}{ Grupe } & \multirow{2}{*}{$\begin{array}{l}\text { Srednja } \\
\text { razlika među } \\
\text { grupama }\end{array}$} & \multirow[b]{2}{*}{ SE } & \multirow[b]{2}{*}{ Sig. } & \multicolumn{2}{|c|}{$\begin{array}{l}95 \% \text { Granica } \\
\text { pouzdanosti }\end{array}$} \\
\hline & & & & & $\begin{array}{l}\text { Donja } \\
\text { granica }\end{array}$ & $\begin{array}{l}\text { Gornja } \\
\text { granica }\end{array}$ \\
\hline \multirow[t]{2}{*}{ I trimestar } & II trimestar & $-0,09$ & 0,06 & 0,13 & $-0,21$ & 0,03 \\
\hline & III trimestar & $-0,52$ & 0,06 & 0,00 & $-0,63$ & $-0,41$ \\
\hline \multirow[t]{2}{*}{ II trimestar } & I trimestar & 0,09 & 0,06 & 0,13 & $-0,03$ & 0,21 \\
\hline & III trimestar & $-0,43$ & 0,06 & 0,00 & $-0,55$ & $-0,31$ \\
\hline \multirow[t]{2}{*}{ III trimestar } & I trimestar & 0,52 & 0,06 & 0,00 & 0,41 & 0,63 \\
\hline & II trimestar & 0,43 & 0,06 & 0,00 & 0,31 & 0,55 \\
\hline
\end{tabular}

Zatim je obavljeno višestruko LSD testiranje cistatina C po trimestrima (Tabela 20).

Statistički značajno najviše prosečne vrednosti cistatina $\mathrm{C}$ bile su u trećem trimestru u odnosu na prvi i drugi trimestar $(p<0,001)$. Međutim, nije bilo statistički značajne razlike vrednosti cistatina $\mathrm{C}$ kod trudnica $\mathrm{u}$ prvom trimestru $\mathrm{u}$ odnosu na trudnice $u$ drugom trimestru $(\mathrm{p}=0,13)$.

Rezultati analize varijanse (ANOVA) recipročnih vrednosti cistatina $\mathrm{C}$ pokazuju da su trudnice imale visoko statistički značajno različite vrednosti 1/cistatin $\mathrm{C}$ u odnosu na trimestre trudnoće $(F=44,317 \mathrm{p}<0,0001)$.

Tabela 21. LSD testiranje među trimestrima prosečnih vrednosti $1 /$ cistatin $C$

\begin{tabular}{|c|c|c|c|c|c|c|}
\hline \multicolumn{7}{|c|}{ 1/cistatin C } \\
\hline \multirow[b]{2}{*}{ Grupe } & \multirow[b]{2}{*}{ Grupe } & \multirow{2}{*}{$\begin{array}{c}\text { Srednja } \\
\text { vrednost } \\
\text { među } \\
\text { grupama }\end{array}$} & \multirow[b]{2}{*}{ SE } & \multirow[b]{2}{*}{ Sig. } & \multicolumn{2}{|c|}{$\begin{array}{l}\text { 95\% Granica } \\
\text { pouzdanosti }\end{array}$} \\
\hline & & & & & $\begin{array}{l}\text { Donja } \\
\text { granica }\end{array}$ & $\begin{array}{l}\text { Gornja } \\
\text { granica }\end{array}$ \\
\hline \multirow[t]{2}{*}{ I trimestar } & II trimestar & 0,16068 & 0,07651 & 0,038 & 0,0090 & 0,3124 \\
\hline & III trimestar & 0,65826 & 0,07269 & 0,000 & 0,5141 & 0,8024 \\
\hline \multirow[t]{2}{*}{ II trimestar } & I trimestar & $-0,16068$ & 0,07651 & 0,038 & $-0,3124$ & $-0,0090$ \\
\hline & III trimestar & 0,49758 & 0,07606 & 0,000 & 0,3468 & 0,6484 \\
\hline \multirow[t]{2}{*}{ III trimestar } & I trimestar & $-0,65826$ & 0,07269 & 0,000 & $-0,8024$ & $-0,5141$ \\
\hline & II trimestar & $-0,49758$ & 0,07606 & 0,000 & $-0,6484$ & $-0,3468$ \\
\hline
\end{tabular}

LSD testiranje je pokazalo da su se statistički značajno razlikovale srednje recipročne vrednosti cistatina $\mathrm{C}$ između sva tri trimestra međusobno, najniže vrednosti su imale trudnice u trećem trimestru (Tabela 21). 


\subsubsection{Međusobna korelacija dobijenih vrednosti kreatinina, klirensa kreatinina, cistatina $C$ i recipročne vrednosti cistatina $C$ kod trudnica}

Analizirana je korelacija kreatinina, klirensa kreatinina, cistatin $\mathrm{C}$ i recipročna vrednost cistatina $\mathrm{C}$ kod svih 109 trudnica bez obzira na gestacionu dob.

Tabela 22. Korelacija koncentracije cistatina C, kreatinina, klirensa kreatinina, i recipročne vrednosti cistatina $\mathrm{C}$ kod trudnica

\begin{tabular}{|c|c|c|c|c|c|}
\hline & & $\begin{array}{c}\text { Kreatinin } \\
\text { u serumu } \\
\mu \mathrm{mol} / \mathrm{l}\end{array}$ & $\begin{array}{c}\text { Klirens } \\
\text { kreatinina } \\
\text { ml/min }\end{array}$ & 1/Cistatin C & $\begin{array}{c}\text { Cistatin } \mathbf{C} \\
\mathrm{mg} / \mathrm{l}\end{array}$ \\
\hline \multirow{3}{*}{$\begin{array}{c}\text { Kreatinin u } \\
\text { serumu } \\
\mu \mathrm{mol} / 1\end{array}$} & R koef. & 1,000 & $-0,316(* *)$ & $-0,340(* *)$ & $0,340(* *)$ \\
\hline & Sig. (p) & . & 0,0001 & 0,0001 & 0,0001 \\
\hline & $\mathrm{N}$ & 109 & 109 & 109 & 109 \\
\hline \multirow{3}{*}{$\begin{array}{c}\text { Klirens } \\
\text { kreatinina } \\
\mathrm{ml} / \mathrm{min}\end{array}$} & R koef. & $-0,316(* *)$ & 1,000 & 0,128 & $-0,126$ \\
\hline & Sig. (p) & 0,0001 & . & 0,129 & 0,133 \\
\hline & $\mathrm{N}$ & 109 & 109 & 109 & 109 \\
\hline \multirow{3}{*}{ cistatin $\mathbf{C ~ m g / l}$} & R koef. & $0,340(* *)$ & $-0,126$ & $-1,000(* *)$ & 1,000 \\
\hline & Sig. (p) & 0,0001 & 0,133 & 0,0001 & . \\
\hline & $\mathrm{N}$ & 109 & 109 & 109 & 109 \\
\hline \multirow{3}{*}{ 1/cistatin C } & R koef. & $-0,340(* *)$ & 0,128 & 1,000 & $-1,000(* *)$ \\
\hline & Sig. (p) & 0,0001 & 0,129 & & 0,0001 \\
\hline & $\mathrm{N}$ & 109 & 109 & 109 & 109 \\
\hline
\end{tabular}

$* * \mathrm{p}<0,01$ postoji značajna korelacija među parametrima

Koncentracija cistatina $\mathrm{C}$ u serumu direktno visoko statistički značajno korelira sa vrednostima kreatinina $(\mathrm{p}<0,0001)$, sa porastom cistatina $\mathrm{C}$ u serumu statistički značajno raste i nivo kreatinina (Tabela 22).

Klirens kreatinina obrnuto statistički neznačajno korelira sa nivoom cistatina $\mathrm{C}$ $(\mathrm{p}>0,05)$, sa porastom klirensa kreatinina opada nivo cistatina $\mathrm{C}$, bez statističke značajnosti. Visina klirensa kreatinina direktno statistički neznačajno korelira sa recipročnim vrednostima cistatin $C(p>0,05)$, sa porastom klirensa kreatinina raste recipročna vrednost cistatina $\mathrm{C}(1 /$ cistatin $\mathrm{C})$ bez statističke značajnosti.

Nivo kreatinina u serumu obrnuto statistički visoko značajno korelira sa klirensom kreatinina $(p<0,0001)$, sa porastom kreatinina u serumu opada klirens kreatinina. 


\subsubsection{Korelacija kreatinina, klirensa kreatinina, cistatina $C$ i recipročne vrednosti cistatina $\mathrm{C}$ kod trudnica u prvom trimestru}

Kod 38 trudnica u prvom trimestru trudnoće koncentracija kreatinina u serumu obrnuto korelira sa vrednostima klirensa kreatinina $(p<0,026)$, sa porastom kreatinina $u$ serumu statistički značajno najčešće opada nivo klirensa kreatinina (Tabela 23).

Tabela 23. Korelacija kreatinina, klirensa kreatinina, cistatina $\mathrm{C}$ i 1/cistatin $\mathrm{C}$ kod trudnica u I trimestru trudnoće

\begin{tabular}{|c|c|c|c|c|c|}
\hline & & $\begin{array}{c}\text { Kreatinin } \\
\text { u serumu } \\
\mu \mathrm{mol} / 1\end{array}$ & $\begin{array}{c}\text { Klirens } \\
\text { kreatinina } \\
\mathrm{ml} / \mathrm{min}\end{array}$ & 1/cistatin C & $\underset{\mathrm{mg} / \mathrm{l}}{\operatorname{cistatin} \mathbf{C}}$ \\
\hline \multirow{3}{*}{$\begin{array}{c}\text { Kreatinin } \mathbf{u} \\
\text { serumu } \\
\mu \mathrm{mol} / 1\end{array}$} & R koef. & 1,000 & $-0,360(*)$ & $-0,396\left(^{*}\right)$ & $0,396(*)$ \\
\hline & Sig. (p) & & 0,026 & 0,014 & 0,014 \\
\hline & $\mathrm{N}$ & 38 & 38 & 38 & 38 \\
\hline \multirow{3}{*}{$\begin{array}{c}\text { Klirens } \\
\text { kreatinina } \\
\mathrm{ml} / \mathrm{min}\end{array}$} & R koef. & $-0,360(*)$ & 1,000 & $0,600(* *)$ & $-0,600(* *)$ \\
\hline & Sig. (p) & 0,026 & 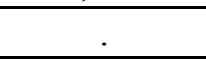 & 0,0001 & 0,0001 \\
\hline & $\mathrm{N}$ & 38 & 38 & 38 & 38 \\
\hline \multirow{3}{*}{$\underset{\mathrm{mg} / \mathrm{l}}{\text { Cistatin } \mathbf{C}}$} & R koef. & $0,396\left(^{*}\right)$ & $-0,600\left(^{* *}\right)$ & $-1,000(* *)$ & 1,000 \\
\hline & Sig. (p) & 0,014 & 0,0001 & 0,0001 & - \\
\hline & $\mathrm{N}$ & 38 & 38 & 38 & 38 \\
\hline \multirow{3}{*}{ 1/cistatin C } & R koef. & $-0,396\left(^{*}\right)$ & $0,600(* *)$ & 1,000 & $-1,000(* *)$ \\
\hline & Sig. (p) & 0,014 & 0,0001 & . & 0,000 \\
\hline & $\mathrm{N}$ & 38 & 38 & 38 & 38 \\
\hline
\end{tabular}

Nivo kreatinina u serumu direktno statistički značajno korelira sa nivoom cistatina $\mathrm{C}(\mathrm{p}<0,014)$, sa rastom kreatinina u serumu najčešće statistički značajno raste i nivo cistatina $\mathrm{C} \mathrm{u}$ prvom trimestru trudnoće, a recipročna vrednost cistatina $\mathrm{C}$ najčešće statistički značajno opada $\mathrm{s}$ porastom kreatinina u serumu (obrnuta korelacija), $(\mathrm{p}<0,014)$.

Klirens kreatinina obrnuto statistički visoko značajno korelira sa koncentracijom cistatina $C(p<0,0001)$, sa porastom klirensa kreatinina opada koncentarcija cistatina $C$ kod trudnica u prvom trimestru trudnoće.

Klirens kreatinina direktno statistički visoko značajno korelira sa recipročnom vrednošću cistatina $\mathrm{C}(\mathrm{p}<0,0001)$, sa porastom klirensa kreatinina statistički značajno najčešće raste recipročna vrednost cistatina $\mathrm{C}$ kod trudnica u prvom trimestru trudnoće. 


\subsubsection{Analiza Receiver Operating Characteristic krive trudnica u prvom trimestru}

Da bi se ispitala specifičnost i osetljivost kreatinina, klirensa kreatinina, cistatina C i 1/cistatin C kod trudnica u prvom trimestru, primenjena je analiza ROC (Receiver Operating Characteristic) krive (Tabela 24).

Tabela 24. Podaci ROC analize za kreatinin, klirens kreatinina, cistatin C i 1/cistatin $\mathrm{C}$ trudnica $\mathrm{u}$ I trimestru

\begin{tabular}{|c|c|c|c|c|c|}
\hline \multirow[b]{2}{*}{ Ispitivane varijable } & \multirow[b]{2}{*}{ AUC } & \multirow[b]{2}{*}{ SE } & \multirow{2}{*}{$\begin{array}{l}\text { Asympto } \\
\text { tic } \\
\text { Sig.(b) }\end{array}$} & \multicolumn{2}{|c|}{$95 \%$ Granica pouzdanosti } \\
\hline & & & & $\begin{array}{c}\text { Donja } \\
\text { garnica }\end{array}$ & $\begin{array}{l}\text { Gornja } \\
\text { granica }\end{array}$ \\
\hline Kreatinin u serumu & 0,303 & 0,044 & 0,000 & 0,216 & 0,390 \\
\hline Klirens kreatinina & 0,535 & 0,052 & 0,519 & 0,434 & 0,636 \\
\hline Cistatin C & 0,140 & 0,030 & 0,000 & 0,081 & 0,199 \\
\hline 1/Cistatin $\mathrm{C}$ & 0,859 & 0,030 & 0,000 & 0,800 & 0,919 \\
\hline
\end{tabular}

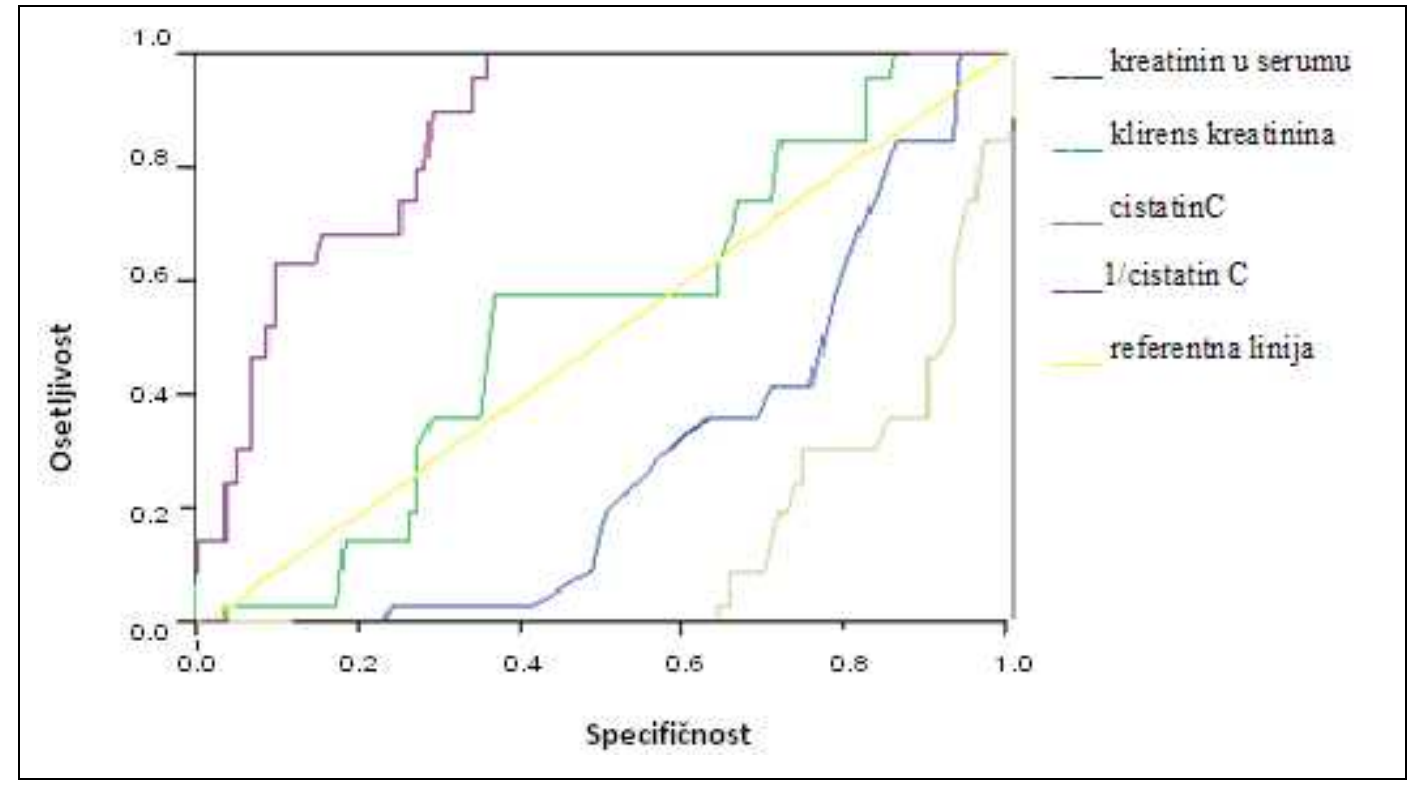

Slika 21. ROC grafik za prvi trimestar

Vrednosti kreatinina u serumu $(0,303 \mathrm{p}<0,0001)$, recipročne vrednosti cistatina $\mathrm{C}$ $(0,859 \mathrm{p}<0,0001)$ i cistatin $\mathrm{C}(0,140 \mathrm{p}<0,0001)$ pod ROC krivom imaju statistički značajnu površinu (Slika 21). Vrednost klirensa kreatinina $(\mathrm{p}=0,519)$ nema statistički značajnu površinu pod krivom u prvom trimestru. Specifičnost i osetljivost $u$ prvom trimestru su najveći za cistatin $\mathrm{C}$. 


\subsubsection{Korelacija nivoa kreatinina, klirensa kreatinina, cistatina $C$ i recipročne vrednosti cistatina $C$ dobijenih kod trudnica u drugom trimestru}

$\mathrm{U}$ grupi od 32 trudnice $\mathrm{u}$ drugom trimestu trudnoće koncentracija kreatinina $\mathrm{u}$ serumu u obrnutoj je korelaciji sa vrednostima klirensa kreatinina $(\mathrm{p}=\mathrm{ns})$, sa porastom kreatinina $\mathrm{u}$ serumu nešto češće opada nivo klirensa kreatinin ali bez statističke značajnosti (Tabela 25).

Tabela 25. Korelacija kreatinina, klirensa kreatinina, cistatina C i 1/cistatin C kod trudnica u drugom trimestru trudnoće

\begin{tabular}{|c|c|c|c|c|c|}
\hline & & $\begin{array}{c}\text { Kreatinin } \\
\text { u serumu } \\
\mu \mathrm{mol} / 1\end{array}$ & $\begin{array}{c}\text { Klirens } \\
\text { kreatinina } \\
\mathrm{ml} / \mathrm{min} \\
\end{array}$ & 1/cistatin $\mathrm{C}$ & $\begin{array}{c}\text { Cistatin } \mathbf{C} \\
\mathrm{mg} / \mathrm{l}\end{array}$ \\
\hline \multirow{3}{*}{$\begin{array}{c}\text { Kreatinin } \mathbf{u} \\
\text { serumu } \\
\mu \mathrm{mol} / 1\end{array}$} & R koef. & 1,000 & $-0,156$ & $-0,501(* *)$ & $0,501(* *)$ \\
\hline & Sig. (p) & -1 & 0,395 & 0,004 & 0,004 \\
\hline & $\mathrm{N}$ & 32 & 32 & 32 & 32 \\
\hline \multirow{3}{*}{$\begin{array}{c}\text { Klirens } \\
\text { kreatinina } \\
\mathrm{ml} / \mathrm{min}\end{array}$} & R koef. & $-0,156$ & 1,000 & 0,096 & $-0,096$ \\
\hline & Sig. (p) & 0,395 & & 0,599 & 0,599 \\
\hline & $\mathrm{N}$ & 32 & 32 & 32 & 32 \\
\hline \multirow{3}{*}{$\begin{array}{c}\text { Cistatin } \mathbf{C} \\
\mathrm{mg} / 1\end{array}$} & R koef. & $0,501(* *)$ & $-0,096$ & $-1,000(* *)$ & 1,000 \\
\hline & Sig. (p) & 0,004 & 0,599 & 0,000 &. \\
\hline & $\mathrm{N}$ & 32 & 32 & 32 & 32 \\
\hline \multirow{3}{*}{ 1/cistatin $C$} & R koef. & $-0,501(* *)$ & 0,096 & 1,000 & $-1,000(* *)$ \\
\hline & Sig. (p) & 0,004 & 0,599 & & 0,000 \\
\hline & $\mathrm{N}$ & 32 & 32 & 32 & 32 \\
\hline
\end{tabular}

$*_{\mathrm{p}}<0,05$ postoji značajna korelacija među parametrima

$* * \mathrm{p}<0,01$ postoji značajna korelacija među parametrima

Kod ovih trudnica postoji direktna statistički značajna korelacija nivoa kreatinina u serumu i koncentracije cistatina $\mathrm{C}(\mathrm{p}<0,004)$, tj. sa porastom kreatinina $\mathrm{u}$ serumu visoko značajno češće raste i nivo cistatina $\mathrm{C}$.

Kod trudnica u drugom trimestru trudnoće klirens kreatinina obrnuto statistički neznačajno korelira sa koncentracijom cistatina $\mathrm{C}(\mathrm{p}=\mathrm{ns})$, a direktno statistički neznačajno korelira sa recipročnim vrednostima cistatina $\mathrm{C}(\mathrm{p}=\mathrm{ns})$. 


\subsubsection{Analiza Receiver Operating Characteristic krive trudnica u drugom trimestru}

Kod trudnica u II trimestru vrednosti cistatina $C(0,741 \mathrm{p}<0,0001)$ i recipročne vrednosti cistatina $C(0,259 \mathrm{p}<0,0001)$ imaju statistički značajnu površinu pod ROC krivom, dok vrednosti kreatinina u serumu $(0,585 \mathrm{p}=0,144)$ i klirensa kreatinina $(\mathrm{p}=0,628)$ nemaju statistički značajnu površinu (Tabela 26$)$.

Tabela 26. Podaci ROC analize za kreatinin, klirens kreatinina, cistatin C i 1/cistatin C trudnica u II trimestru

\begin{tabular}{c|c|c|c|c|c}
\hline \multirow{2}{*}{ Ispitivane varijable } & AUC & SE & \multirow{2}{*}{$\begin{array}{c}\text { Asymptoti } \\
\text { c Sig.(b) }\end{array}$} & $\begin{array}{c}\text { 95\% Granica pouzdanosti } \\
\text { garnica }\end{array}$ & $\begin{array}{c}\text { Donja } \\
\text { garnica }\end{array}$ \\
\hline Kreatinin u serumu & 0,585 & 0,065 & 0,144 & 0,458 & 0,712 \\
\hline Klirens kreatinina & 0,472 & 0,058 & 0,628 & 0,358 & 0,586 \\
\hline Cistatin C & 0,259 & 0,046 & 0,000 & 0,169 & 0,349 \\
\hline 1/cistatin C & 0,741 & 0,046 & 0,000 & 0,652 & 0,831 \\
\hline
\end{tabular}

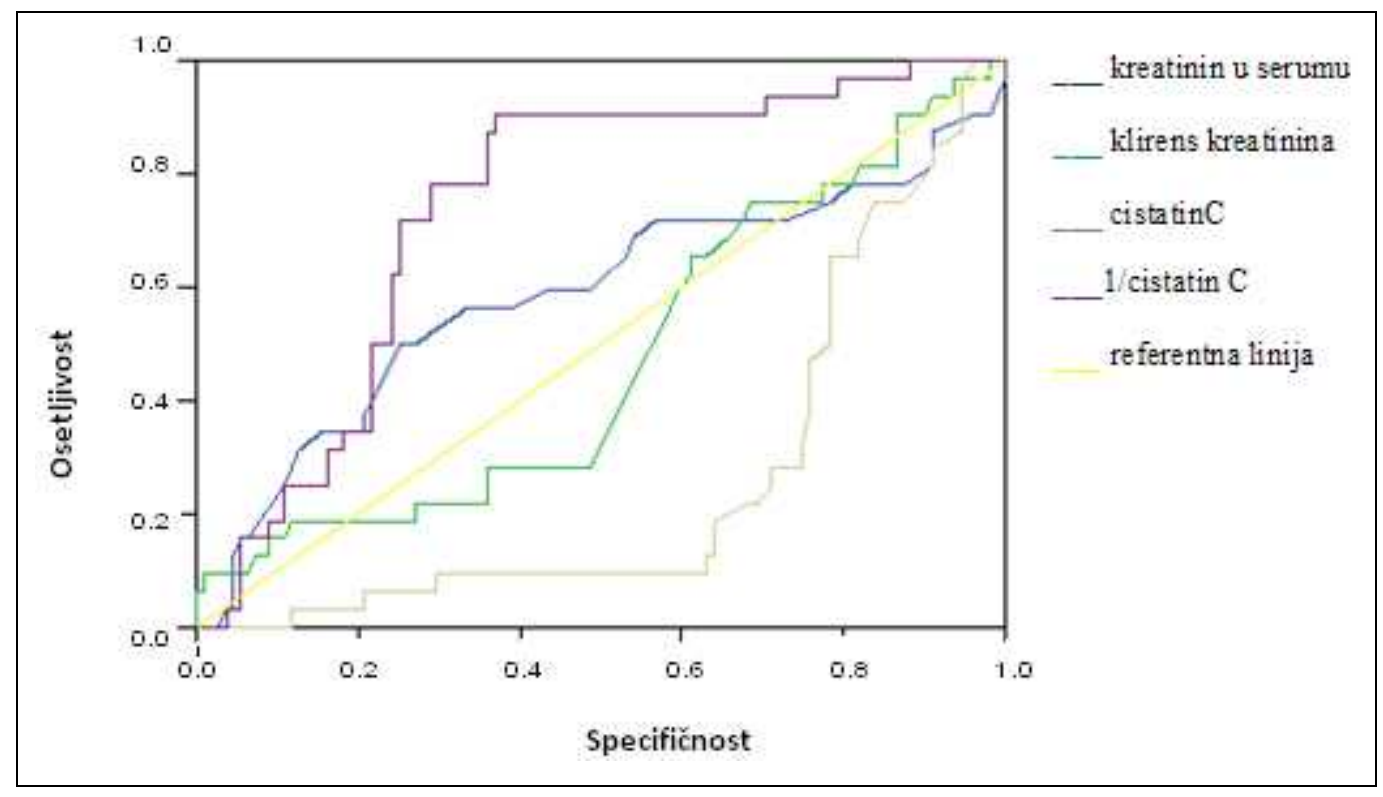

Slika 22. ROC grafik za drugi trimestar

U drugom trimestru najveća specifičnost i osetljivost je za cistatin C (Slika 22). 


\subsubsection{Korelacija nivoa kreatinina, klirensa kreatinina, cistatina $\mathrm{C}$ i recipročne vrednosti cistatina $C$ kod trudnica u trećem trimestru}

Kod 39 trudnica u trećem trimestru trudnoće koncentracija kreatinina u serumu obrnuto statistički visoko značajno korelira sa klirensom kreatinina $(\mathrm{p}<0,0001)$, porast vrednosti kreatinina u serumu prati smanjivanje klirensa kreatinina (Tabela 27).

Tabela 27. Korelacija kreatinina, klirensa kreatinina, cistatina C i 1/cistatin C kod trudnica u trećem trimestru trudnoće

\begin{tabular}{|c|c|c|c|c|c|}
\hline & & $\begin{array}{c}\text { Kreatinin } \\
\text { u serumu } \\
\mu \mathrm{mol} / 1\end{array}$ & $\begin{array}{c}\text { Klirens } \\
\text { kreatinina } \\
\mathrm{ml} / \mathrm{min}\end{array}$ & 1/cistatin C & $\underset{\mathrm{mg} / \mathrm{l}}{\operatorname{cistatin} \mathbf{C}}$ \\
\hline \multirow{3}{*}{$\begin{array}{c}\text { Kreatinin u } \\
\text { serumu } \\
\mu \mathrm{mol} / 1\end{array}$} & R koef. & 1 & $-0,557(* *)$ & $-0,402(*)$ & $0,457(* *)$ \\
\hline & Sig. (p) & . & 0,000 & 0,011 & 0,003 \\
\hline & $\mathrm{N}$ & 39 & 39 & 39 & 39 \\
\hline \multirow{3}{*}{$\begin{array}{c}\text { Klirens } \\
\text { kreatinina } \\
\mathrm{ml} / \mathrm{min}\end{array}$} & R koef. & $-0,557(* *)$ & 1 & 0,112 & $-0,190$ \\
\hline & Sig. (p) & 0,000 & . & 0,497 & 0,247 \\
\hline & $\mathrm{N}$ & 39 & 39 & 39 & 39 \\
\hline \multirow{3}{*}{$\begin{array}{c}\text { Cistatin } \mathbf{C} \\
\mathrm{mg} / \mathrm{l}\end{array}$} & R koef. & $0,457(* *)$ & $-0,190$ & $-0,959(* *)$ & 1 \\
\hline & Sig. (p) & 0,003 & 0,247 & 0,000 & - \\
\hline & $\mathrm{N}$ & 39 & 39 & 39 & 39 \\
\hline \multirow{2}{*}{ 1/cistatin C } & R koef. & $-0,402(*)$ & 0,112 & 1 & $-0,959(* *)$ \\
\hline & Sig. (p) & 0,011 & 0,497 & . & 0,000 \\
\hline
\end{tabular}

$* * p<0,01-$ postoji značajna korelacija među parametrima $* \mathrm{p}<0,05-$ postoji značajna korelacija među parametrima

Trudnice u trećem trimestru trudnoće imale su direktno statistički visoko značajnu korelaciju koncentarcije kreatinina $u$ serumu sa koncentracijom cistatina $C(R=0,457$ $\mathrm{p}<0,003$ ) tako da porast vrednosti kreatinina u serumu najčešće prati visoko statistički značajano porast nivoa cistatina $\mathrm{C}$, odnosno opada značajno recipročna vrednost cistatina $\mathrm{C}$.

Klirens kreatinina obrnuto statitstički neznačajno korelira sa koncentracijom cistatina $\mathrm{C}$, sa porastom klirensa kreatinina opada nivo cistatina $\mathrm{C}$, dok je sa recipročnom vrednošću cistatina $\mathrm{C}$ u direktnoj korelaciji, ali ne statistički značajnoj. 


\subsubsection{Analiza Receiver Operating Characteristic krive trudnica u trećem trimestru}

Kod trudnica u III trimestru vrednosti cistatina C $(0,949$ p $<0,0001)$ i $1 /$ cistatin C $(0,052 \mathrm{p}<0,0001)$, pod ROC krivom imaju statistički značajnu površinu, kao i vrednost kreatinina u serumu $(0,595 \mathrm{p}<0,05)$. Klirens kreatinina je bez statistički značajne površine pod krivom $(\mathrm{p}=0,868)$ u trećem trimestru (Tabela 28$)$.

Tabela 28. Podaci ROC analize za kreatinin, klirens kreatinina, cistatin C i 1/cistatin C trudnica u III trimestru

\begin{tabular}{|c|c|c|c|c|c|}
\hline \multirow[t]{2}{*}{ Ispitivane varijable } & \multirow[b]{2}{*}{ AUC } & \multirow[b]{2}{*}{ SE } & \multirow{2}{*}{$\begin{array}{l}\text { Asymptoti } \\
\text { c Sig.(b) }\end{array}$} & \multicolumn{2}{|c|}{$95 \%$ Interval pouzdanosti } \\
\hline & & & & $\begin{array}{c}\text { Donja } \\
\text { garnica }\end{array}$ & $\begin{array}{c}\text { Donja } \\
\text { garnica }\end{array}$ \\
\hline Kreatinin u serumu & 0,595 & 0,048 & 0,050 & 0,502 & 0,688 \\
\hline Klirens kreatinina & 0,492 & 0,049 & 0,868 & 0,396 & 0,587 \\
\hline Cistatin $\mathrm{C}$ & 0,949 & 0,019 & 0,000 & 0,911 & 0,986 \\
\hline 1/cistatin C & 0,052 & 0,019 & 0,000 & 0,014 & 0,089 \\
\hline
\end{tabular}

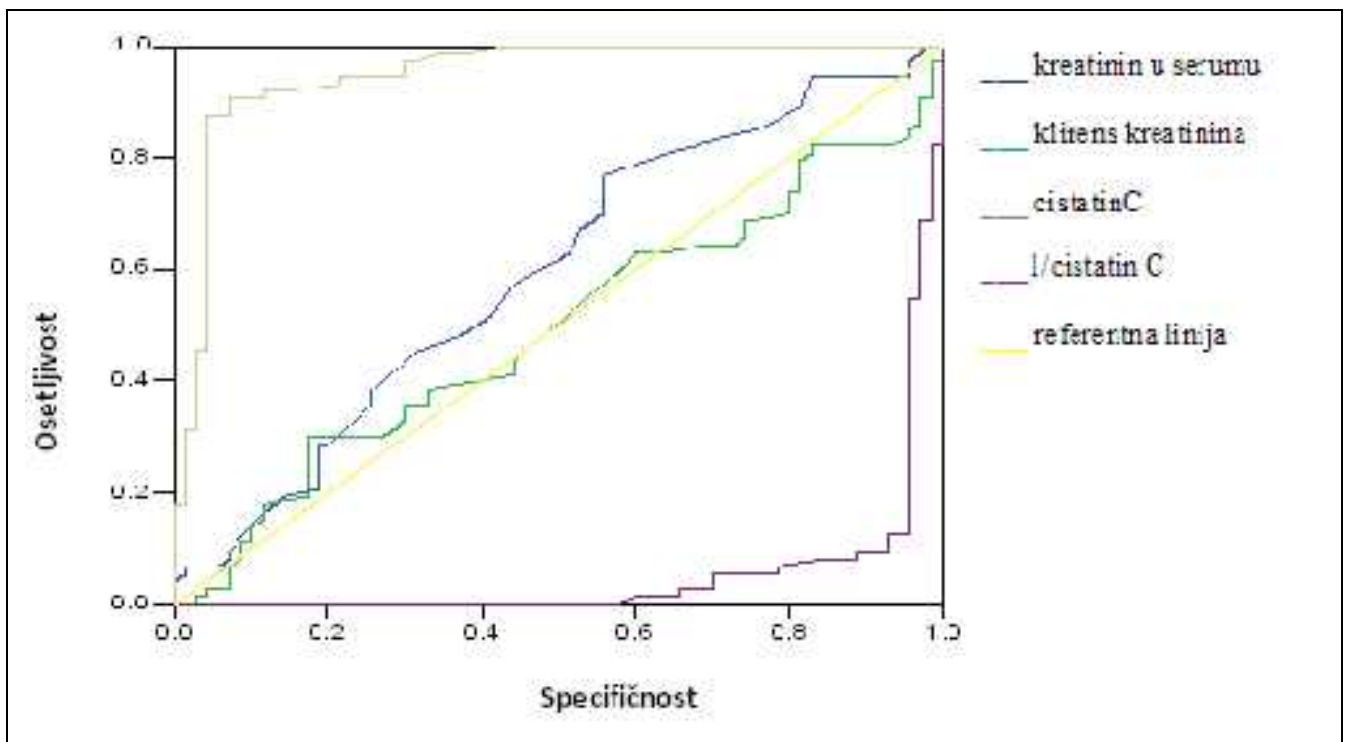

Slika 23. ROC grafik za treći trimestar

Kod trudnica $\mathrm{u}$ III trimestru vrednost kreatinina $\mathrm{u}$ serumu imaju manju specifičnost $\mathrm{i}$ osetljivost $\mathrm{u}$ odnosu na cistatin $\mathrm{C}$, koji kao i $1 /$ cistatin $\mathrm{C}$ ima visoku osetljivost i specifičnost (Slika 23). 


\subsubsection{Prosečne vrednosti klirensa kreatinina, kreatinina i cistatina $C$ kod trudnica u odnosu na životnu dob trudnica}

Da bi ispitiali kako životna dob trudnica utiče na vednosti kreatinina, klirensa kreatinina, cistatina C i 1/cistatin C trudnice su grupisane prema starosti u pet dobnih grupa koje obuhvataju petogodišnji period. U prvoj dobnoj grupi su bile trudice životne dobi od 20 do 24,9 godina, drugu dobnu grupu su činile trudice od 25 do 29,9 godina. U trećoj dobnoj grupi su bile trudnice starosti od 30 do 34,9 godina a u četvrtoj dobnoj grupi trudnice starosti od 35 do 39,9 godina, dok su trudnice starije od 40 godina bile $u$ petoj grupi (Slika 24).

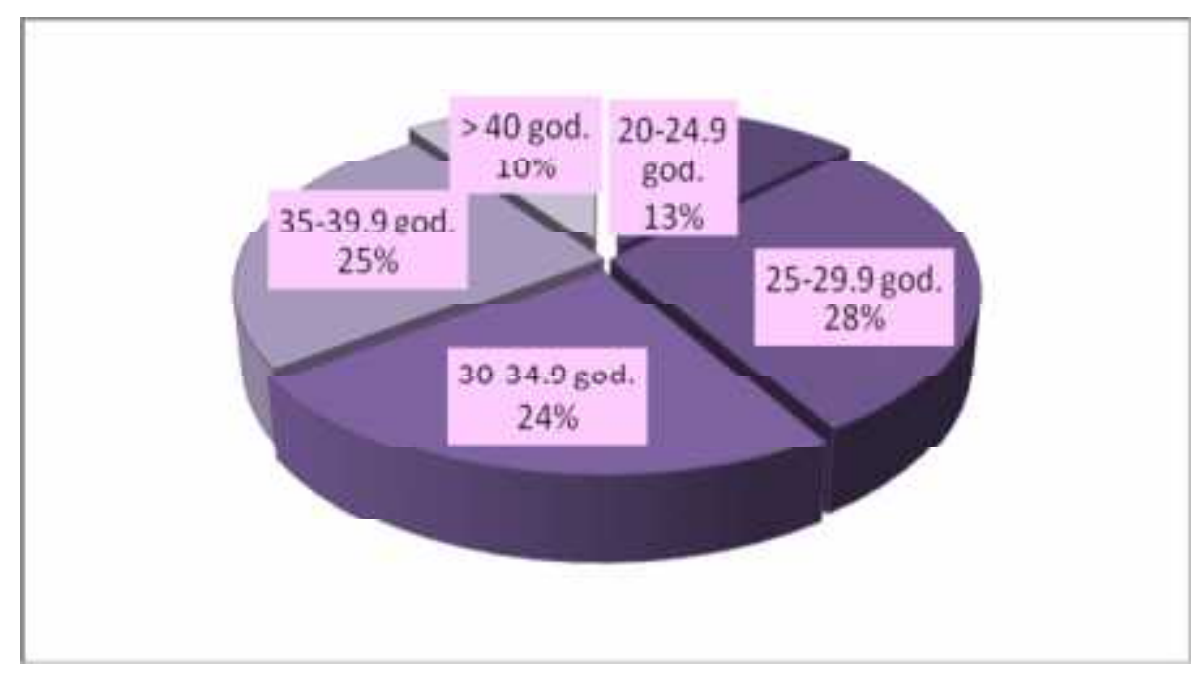

Slika 24. Distribucija trudnica prema starosnoj dobi

\subsubsection{Uticaj životne dobi trudnica na nivo kreatinina}

Najvišu koncentraciju kreatinina u serumu $87 \mu \mathrm{mol} / 1$ imala je trudnica iz grupe preko 40 godina, a najnižu, $45 \mu \mathrm{mol} / 1$, imala je trudnica iz grupe 35-39,9 godina (Tabela 29).

Trudnice koje pripadaju dobnoj grupi preko 40 godina imaju statistički značajno najviše prosečne vrednosti kreatinina u serumu u odnosu na sve druge posmatrane dobne grupe $(\mathrm{F}=2,75 \mathrm{p}<0,03)($ Slika 25). 
Tabela 29. Distribucija koncentracija kreatinina trudnica zavisno od dobne grupe.

\begin{tabular}{|l|c|c|c|c|c|}
\hline \multirow{2}{*}{$\begin{array}{l}\text { Dobne } \\
\text { grupe }\end{array}$} & \multicolumn{6}{|c|}{ Kreatinin $(\boldsymbol{\mu m o l} / \mathbf{l})$} \\
\cline { 2 - 6 } & $\mathbf{N}$ & $\overline{\mathbf{x}}$ & $\mathrm{SD}$ & Min & Maks. \\
\hline $\mathbf{2 0 - \mathbf { 2 4 , 9 }}$ & 14 & 62,36 & 10,49 & 49 & 77 \\
\hline $\mathbf{2 5}-\mathbf{2 9 , 9}$ & 31 & 62,35 & 9,73 & 46 & 84 \\
\hline $\mathbf{3 0 - 3 4 , 9}$ & 26 & 63,23 & 6,37 & 50 & 82 \\
\hline $\mathbf{3 5 - 3 9 , 9}$ & 27 & 61,93 & 11,51 & 45 & 83 \\
\hline$=>\mathbf{4 0}$ & 11 & 72,64 & 10,82 & 53 & 87 \\
\hline Ukupno & $\mathbf{1 0 9}$ & $\mathbf{6 3 , 5 0}$ & $\mathbf{1 0 , 0 7}$ & $\mathbf{4 5}$ & $\mathbf{8 7}$ \\
\hline
\end{tabular}

Tabela 30. LSD testiranje prosečnih vrednosti kreatinina među dobim grupama trudnica

\begin{tabular}{|c|c|c|c|c|c|}
\hline \multicolumn{6}{|c|}{ Kreatinin $\mu \mathrm{mol} / \mathrm{l}$} \\
\hline \multirow[b]{2}{*}{$\begin{array}{l}\text { Dobne } \\
\text { grupe }\end{array}$} & \multirow[b]{2}{*}{$\begin{array}{l}\text { Dobne } \\
\text { grupe }\end{array}$} & \multirow[b]{2}{*}{$\begin{array}{c}\text { Srednja } \\
\text { razlika među } \\
\text { grupama }\end{array}$} & \multirow[b]{2}{*}{ Sig } & \multicolumn{2}{|c|}{$95 \%$ Granica pouzdanosti } \\
\hline & & & & $\begin{array}{l}\text { Donja } \\
\text { granica }\end{array}$ & $\begin{array}{l}\text { Gornja } \\
\text { granica }\end{array}$ \\
\hline \multirow[t]{4}{*}{$20-24,9$} & $25-29,9$ & 0,002304 & 1,00 & $-6,2288163$ & 6,23342456 \\
\hline & $30-34,9$ & $-0,87363$ & 0,79 & $-7,2884402$ & 5,54118743 \\
\hline & $35-39,9$ & 0,431217 & 0,89 & $-5,9418838$ & 6,80431762 \\
\hline & $=>40$ & $-10,2792$ & 0,01 & $-18,075985$ & $-2,4824567$ \\
\hline \multirow[t]{4}{*}{$25-29,9$} & $20-24,9$ & $-0,0023$ & 1,00 & $-6,2334246$ & 6,22881626 \\
\hline & $30-34,9$ & $-0,87593$ & 0,74 & $-6,0219883$ & 4,27012726 \\
\hline & $35-39,9$ & 0,428913 & 0,87 & $-4,665053$ & 5,52287852 \\
\hline & $=>40$ & $-10,2815$ & 0,00 & $-17,072814$ & $-3,490236$ \\
\hline \multirow[t]{4}{*}{$30-34,9$} & $20-24,9$ & 0,873626 & 0,79 & $-5,5411874$ & 7,28844018 \\
\hline & $25-29,9$ & 0,875931 & 0,74 & $-4,2701273$ & 6,0219883 \\
\hline & $35-39,9$ & 1,304843 & 0,63 & $-4,0122481$ & 6,62193476 \\
\hline & $=>40$ & $-9,40559$ & 0,01 & $-16,365808$ & $-2,4453803$ \\
\hline \multirow{4}{*}{$35-39,9$} & $20-24,9$ & $-0,43122$ & 0,89 & $-6,8043176$ & 5,94188376 \\
\hline & $25-29,9$ & $-0,42891$ & 0,87 & $-5,5228785$ & 4,66505295 \\
\hline & $30-34,9$ & $-1,30484$ & 0,63 & $-6,6219348$ & 4,01224815 \\
\hline & $=>40$ & $-10,7104$ & 0,00 & $-17,632226$ & $-3,7886492$ \\
\hline \multirow[t]{4}{*}{$=>40$} & $20-24,9$ & 10,27922 & 0,01 & 2,4824567 & 18,0759849 \\
\hline & $25-29,9$ & 10,28152 & 0,00 & 3,490236 & 17,0728139 \\
\hline & $30-34,9$ & 9,405594 & 0,01 & 2,4453803 & 16,3658085 \\
\hline & $35-39,9$ & 10,71044 & 0,00 & 3,7886492 & 17,6322262 \\
\hline
\end{tabular}

$*_{\mathrm{p}}<0,05$ postoji značajna korelacija među parametrima 
Višestruke komparacije-LSD testiranje je pokazalo da među ostalim dobnim grupama ne postoji statistički značajna razlika u vrednostima kreatinina (Tabela 30).

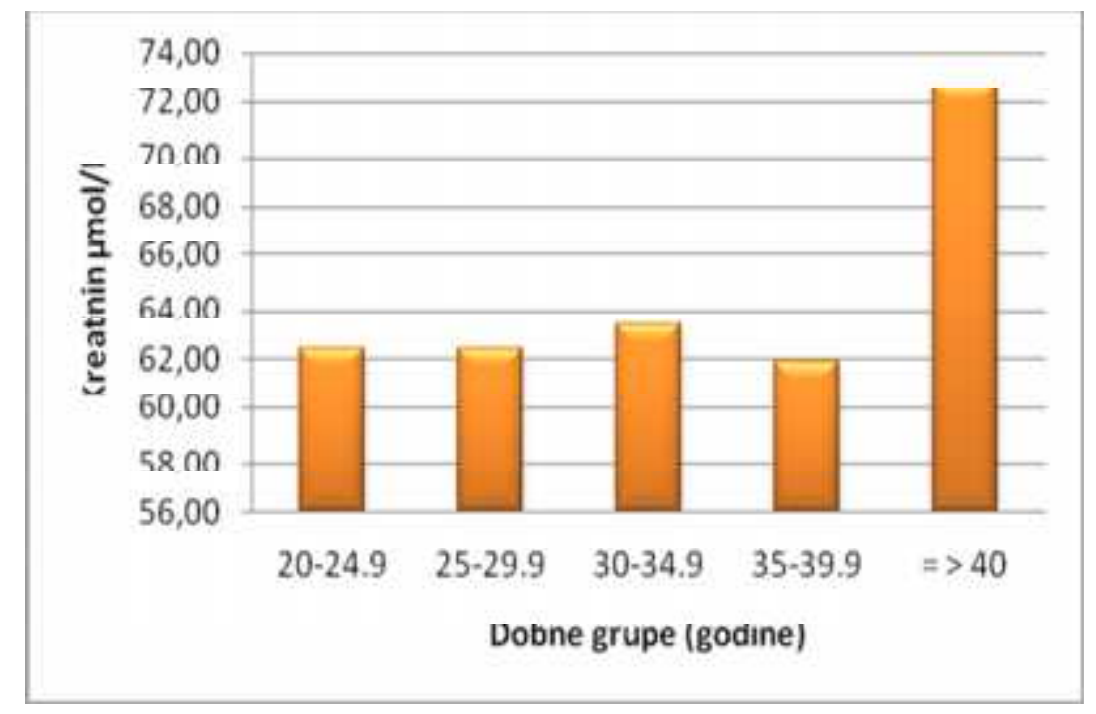

Slika 25. Vrednosti kreatinina u zavisnosti od dobne grupe trudnica

\subsubsection{Uticaj životne dobi trudnica na vrednosti klirensa kreatinina}

Analiza klirensa kreatinina po dobnim grupama je pokazala da je najvišu vrednost $169,2 \mathrm{ml} / \mathrm{min}$ imala trudnica u dobnoj grupi od 20 do 24,9 godina, dok je najnižu vrednost klirensa kreatinina, $63 \mathrm{ml} / \mathrm{min}$, imala trudnica u dobnoj grupi preko 40 godina (Tabela 31).

Tabela 31. Distribucija vrednosti klirensa kreatinina zavisno od dobne grupe trudnica

\begin{tabular}{|l|c|c|c|c|c|}
\hline \multirow{2}{*}{$\begin{array}{l}\text { Dobne } \\
\text { grupe }\end{array}$} & \multicolumn{5}{|c|}{ Klirens kreatinina (ml/min) } \\
\cline { 2 - 6 } & $\mathbf{N}$ & $\overline{\mathbf{x}}$ & SD & Min & Maks. \\
\hline $\mathbf{2 0 - \mathbf { 2 4 , 9 }}$ & 14 & 110,27 & 20,89 & 90 & 169,2 \\
\hline $\mathbf{2 5}-\mathbf{2 9 , 9}$ & 31 & 98,46 & 12,95 & 67,8 & 119,4 \\
\hline $\mathbf{3 0 - \mathbf { 3 4 , 9 }}$ & 26 & 109,98 & 18,55 & 79,8 & 159 \\
\hline $\mathbf{3 5}-\mathbf{3 9 , 9}$ & 27 & 112,13 & 18,15 & 70,2 & 150,6 \\
\hline$=>\mathbf{4 0}$ & 11 & 108,33 & 34,00 & 63 & 162,6 \\
\hline Ukupno & 109 & 107,11 & 19,91 & 63 & 169,2 \\
\hline
\end{tabular}




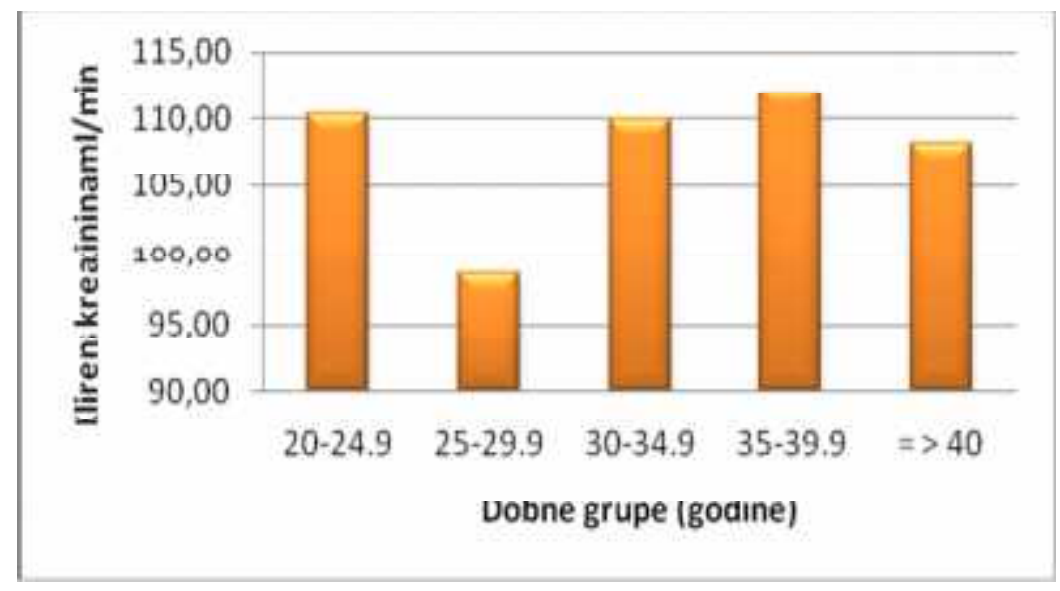

Slika 26. Klirens keatinina u odnosu na starosnu dob trudnica

Najnižu prosečnu vrednost klirensa kreatinina imale su trudnice koje su u dobnoj grupi 25-29,9 godina dok su najviši prosečni klirens kreatinina imale trudnice životne dobi 35-39,9 godina (Slika 26).

Tabela 32. LSD testiranje prosečnih vrednosti klirensa kreatinina medju dobim grupama trudnica

\begin{tabular}{|c|c|c|c|c|c|}
\hline \multicolumn{6}{|c|}{ Klirens kreatinina (ml/min) } \\
\hline \multirow[b]{2}{*}{$\begin{array}{l}\text { Dobne } \\
\text { grupe }\end{array}$} & \multirow[b]{2}{*}{$\begin{array}{l}\text { Dobne } \\
\text { grupe }\end{array}$} & \multirow[b]{2}{*}{$\begin{array}{c}\text { Srednja } \\
\text { razlika među } \\
\text { grupama }\end{array}$} & \multirow[b]{2}{*}{ Sig. } & \multicolumn{2}{|c|}{$95 \%$ Interval pouzdanosti } \\
\hline & & & & $\begin{array}{l}\text { Donja } \\
\text { granica }\end{array}$ & $\begin{array}{l}\text { Gornja } \\
\text { granica }\end{array}$ \\
\hline \multirow[t]{4}{*}{$20-24,9$} & $25-29,9$ & 11,81336 & 0,06 & $-0,6205914$ & 24,2473195 \\
\hline & $30-34,9$ & 0,286813 & 0,96 & $-12,513695$ & 13,0873216 \\
\hline & $35-39,9$ & $-1,8619$ & 0,77 & $-14,579176$ & 10,8553668 \\
\hline & $=>40$ & 1,944156 & 0,80 & $-13,61398$ & 17,5022917 \\
\hline \multirow{4}{*}{$25-29,9$} & $20-24,9$ & $-11,8134$ & 0,06 & $-24,24732$ & 0,62059141 \\
\hline & $30-34,9$ & $-11,5266$ & 0,03 & $-21,795307$ & $-1,2577952$ \\
\hline & $35-39,9$ & $-13,6753$ & 0,01 & $-23,840077$ & $-3,5104607$ \\
\hline & $=>40$ & $-9,86921$ & 0,15 & $-23,420958$ & 3,68254147 \\
\hline \multirow[t]{4}{*}{$30-34,9$} & $20-24,9$ & $-0,28681$ & 0,96 & $-13,087322$ & 12,5136952 \\
\hline & $25-29,9$ & 11,52655 & 0,03 & 1,2577952 & 21,7953066 \\
\hline & $35-39,9$ & $-2,14872$ & 0,69 & $-12,758765$ & 8,46132872 \\
\hline & $=>40$ & 1,657343 & 0,81 & $-12,231491$ & 15,5461758 \\
\hline \multirow[t]{4}{*}{$35-39,9$} & $20-24,9$ & 1,861905 & 0,77 & $-10,855367$ & 14,5791763 \\
\hline & $25-29,9$ & 13,67527 & 0,01 & 3,5104607 & 23,8400769 \\
\hline & $30-34,9$ & 2,148718 & 0,69 & $-8,4613287$ & 12,7587646 \\
\hline & $=>40$ & 3,806061 & 0,59 & $-10,006096$ & 17,6182171 \\
\hline \multirow[t]{4}{*}{$=>40$} & $20-24,9$ & $-1,94416$ & 0,80 & $-17,502292$ & 13,61398 \\
\hline & $25-29,9$ & 9,869208 & 0,15 & $-3,6825415$ & 23,4209579 \\
\hline & $30-34,9$ & $-1,65734$ & 0,81 & $-15,546176$ & 12,2314905 \\
\hline & $35-39,9$ & $-3,80606$ & 0,59 & $-17,618217$ & 10,0060959 \\
\hline
\end{tabular}

$* \mathrm{p}<0,05$ postoji značajna korelacija među parametrima 
ANOVA testom nije dokazana statistički značajna razlika u vrednostima klirensa kreatinina među grupama $(\mathrm{F}=2,22 \mathrm{p}<0,07)$.

Rezultati LSD testiranja su pokazali da su vrednosti klirensa kreatinina statistički značajno različite, niže, samo kod trudnica životne dobi 25-29,9 godina u odnosu na trudnice životne dobi 30-34,9 godina $(\mathrm{p}=0,03)$ i 35-39,9 godina $(\mathrm{p}=0,01)$ (Tabela 32).

\subsubsection{Uticaj životne dobi trudnica na nivo cistatina $\mathrm{C}$}

Najvišu koncentraciju cistatina $\mathrm{C}$ u serumu $1,93 \mathrm{mg} / \mathrm{l}$ je imala trudnica iz dobne grupe preko 40 godina dok je najniža vrednost bila $0,35 \mathrm{mg} / 1$ kod trudnice iz grupe $20-$ 24,9 godina (Tabela 33).

Tabela 33. Distribucija koncentracija cistatina $\mathrm{C}$ zavisno od dobne grupe trudnica

\begin{tabular}{|l|c|c|c|c|c|}
\hline \multirow{2}{*}{$\begin{array}{l}\text { Dobne } \\
\text { grupe }\end{array}$} & \multicolumn{5}{|c|}{ Cistatin C (mg/l) } \\
\cline { 2 - 6 } & $\mathbf{N}$ & $\overline{\mathbf{x}}$ & $\mathbf{S D}$ & Min & Maks. \\
\hline $\mathbf{2 0 - \mathbf { 2 4 , 9 }}$ & 14 & 0,80 & 0,33 & 0,35 & 1,63 \\
\hline $\mathbf{2 5}-\mathbf{2 9 , 9}$ & 31 & 0,87 & 0,28 & 0,58 & 1,81 \\
\hline $\mathbf{3 0 - \mathbf { 3 4 , 9 }}$ & 26 & 1,01 & 0,37 & 0,53 & 1,71 \\
\hline $\mathbf{3 5}-\mathbf{3 9 , 9}$ & 27 & 0,80 & 0,27 & 0,54 & 1,63 \\
\hline $\mathbf{=} \mathbf{4 0}$ & 11 & 1,16 & 0,43 & 0,55 & 1,93 \\
\hline Ukupno & $\mathbf{1 0 9}$ & $\mathbf{0 , 9 0}$ & $\mathbf{0 , 3 4}$ & $\mathbf{0 , 3 5}$ & $\mathbf{1 , 9 3}$ \\
\hline
\end{tabular}

Testiranje među grupama (ANOVA) je pokazalo da na vrednost cistatina $\mathrm{C}$ statistički značajno utiče životna dob trudnica tj. da starenjem cistatin $\mathrm{C}$ uglavnom raste $(\mathrm{F}=3,65 \mathrm{p}<0,01)($ Slika 27). 


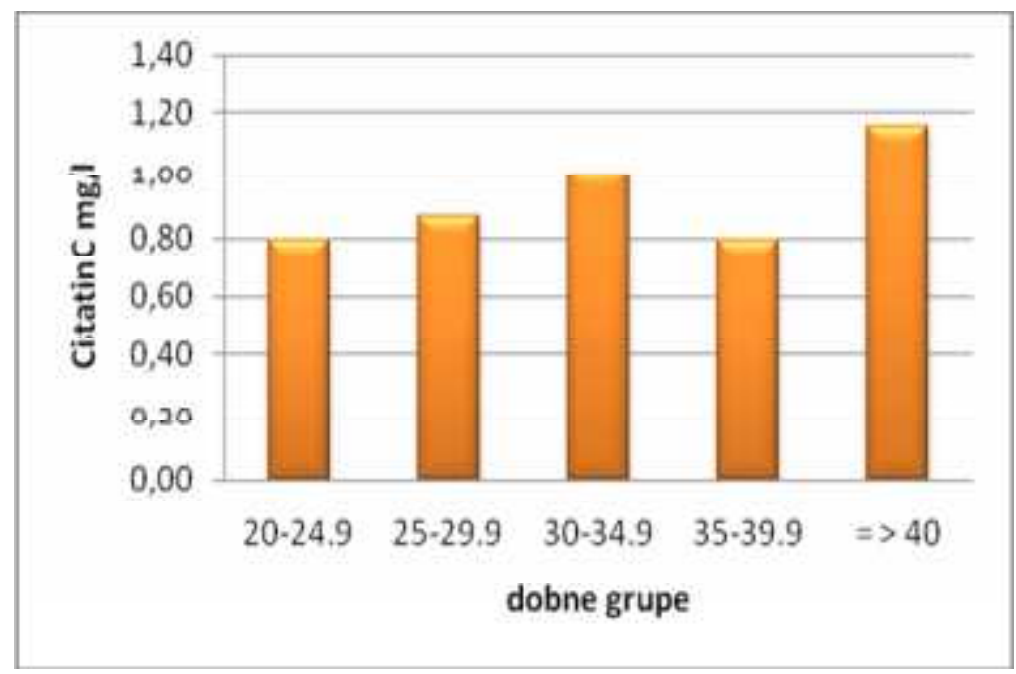

Slika 27. Vrednosti cistatina C zavisno od životne dobi trudnica

Tabela 34. LSD testiranje prosečnih vrednosti cistatina $\mathrm{C}$ među dobim grupama trudnica

\begin{tabular}{|c|c|c|c|c|c|}
\hline \multirow{3}{*}{$\begin{array}{l}\text { Dobne } \\
\text { grupe }\end{array}$} & \multicolumn{5}{|c|}{ Cistatin C mg/l } \\
\hline & \multirow{2}{*}{$\begin{array}{l}\text { Dobne } \\
\text { grupe }\end{array}$} & \multirow{2}{*}{$\begin{array}{c}\text { Srednja } \\
\text { razlika } \\
\text { među } \\
\text { grupama }\end{array}$} & \multirow{2}{*}{ Sig. } & \multicolumn{2}{|c|}{ 95\% Granica pouzdanosti } \\
\hline & & & & $\begin{array}{l}\text { Donja } \\
\text { granica }\end{array}$ & $\begin{array}{l}\text { Gornja } \\
\text { granica }\end{array}$ \\
\hline \multirow[t]{4}{*}{$20-24,9$} & $25-29,9$ & $-0,06906$ & 0,51 & $-0,2751272$ & 0,13701658 \\
\hline & $30-34,9$ & $-0,21473$ & 0,05 & $-0,4268722$ & $-0,0025784$ \\
\hline & $35-39,9$ & 0,00 & 1,00 & $-0,2106351$ & 0,21089964 \\
\hline & $=>40$ & $-0,35994$ & 0,01 & $-0,617785$ & $-0,1020852$ \\
\hline \multirow[t]{4}{*}{$25-29,9$} & $20-24,9$ & 055 & 0,51 & $-0,1370166$ & 0,27512718 \\
\hline & $30-34,9$ & $-0,14567$ & 0,09 & $-0,3158573$ & 0,02451736 \\
\hline & $35-39,9$ & 0,06 & 0,42 & $-0,099277$ & 0,23765216 \\
\hline & $=>40$ & $-0,29088$ & 0,01 & $-0,5154772$ & $-0,0662823$ \\
\hline \multirow[t]{4}{*}{$30-34,9$} & $20-24,9$ & 0,214725 & 0,05 & 0,0025784 & 0,42687215 \\
\hline & $25-29,9$ & 0,1 & 0,09 & $-0,0245174$ & 0,31585731 \\
\hline & $35-39,9$ & 0,214 & 0,02 & 0,0390139 & 0,39070121 \\
\hline & $=>40$ & $-0,1$ & 0,21 & $-0,3753938$ & 0,08497424 \\
\hline \multirow[t]{4}{*}{$35-39,9$} & $20-24,9$ & $-0,00013$ & 1,00 & $-0,2108996$ & 0,21063509 \\
\hline & $25-29,9$ & $-0,06919$ & 0,42 & $-0,2376522$ & 0,09927701 \\
\hline & $30-34,9$ & $-0,21486$ & 0,02 & $-0,3907012$ & $-0,0390139$ \\
\hline & $=>40$ & $-0,36007$ & 0,00 & $-0,5889806$ & $-0,1311541$ \\
\hline \multirow[t]{4}{*}{$=>40$} & $20-24,9$ & 0,359935 & 0,01 & 0,1020852 & 0,61778497 \\
\hline & $25-29,9$ & 088 & 0,01 & 0,0662823 & 0,5154772 \\
\hline & 30 & 0,14521 & 0,21 & $-0,0849742$ & 0,37539382 \\
\hline & $35-39,9$ & 0,360067 & 0,00 & 0,1311541 & 0,58898058 \\
\hline
\end{tabular}

$* \mathrm{p}<0,05$ postoji značajna korelacija među parametrima 
LSD testiranje je pokazalo da su vrednosti cistatina $\mathrm{C}$ trudnica koje su starije od 40 godina statistički značajno više $(\mathrm{p}<0,01)$ u odnosu na dobne grupe 20-24,9, 25-29,9 i 35-39,9 godina. Uz to grupa od 30-34,9 godina ima statistički značajno više $(p<0,05)$ vrednosti cistatina $\mathrm{C}$ u odnosu na grupu od 35-39,9 godina (Tabela 34).

\subsubsection{Uticaj životne dobi trudnica na recipročnu vrednost cistatina $C$}

Najviša recipročna vrednost cistatina $C$ je iznosila 2,86 za trudnicu iz grupe 20 24,9 godina dok je najniža vrednost bila 0,52 kod trudnice preko 40 godina, (Tabela $35)$.

Tabela 35. Distribucija recipročnih vrednosti cistatina $\mathrm{C} u$ odnosu na životnu dob trudnica

\begin{tabular}{|l|c|c|c|c|c|}
\hline \multirow{2}{*}{$\begin{array}{l}\text { Dobne } \\
\text { grupe }\end{array}$} & \multicolumn{5}{|c|}{ 1/Cistatin C } \\
\cline { 2 - 6 } & $\mathbf{N}$ & $\overline{\mathbf{x}}$ & $\mathbf{S d}$ & Min & Maks. \\
\hline $\mathbf{2 0 - \mathbf { 2 4 , 9 }}$ & 14 & 1,47 & 0,66 & 0,61 & 2,86 \\
\hline $\mathbf{2 5}-\mathbf{2 9 , 9}$ & 31 & 1,24 & 0,31 & 0,55 & 1,72 \\
\hline $\mathbf{3 0 - \mathbf { 3 4 , 9 }}$ & 26 & 1,13 & 0,42 & 0,58 & 1,89 \\
\hline $\mathbf{3 5}-\mathbf{3 9 , 9}$ & 27 & 1,36 & 0,34 & 0,61 & 1,85 \\
\hline $\mathbf{=} \mathbf{4 0}$ & 11 & 0,98 & 0,38 & 0,52 & 1,81 \\
\hline Ukupno & $\mathbf{1 0 9}$ & $\mathbf{1 , 2 5}$ & $\mathbf{0 , 4 3}$ & $\mathbf{0 , 5 2}$ & $\mathbf{2 , 8 6}$ \\
\hline
\end{tabular}

ANOVA testom je dokazana statistički značajna razlika prosečnih recipročnih vrednosti cistatina $\mathrm{C}$ u odnosu na dobnu grupu kojoj trudnice pripadaju $(\mathrm{F}=3,22 \mathrm{p}<0,02)($ Slika 28). 


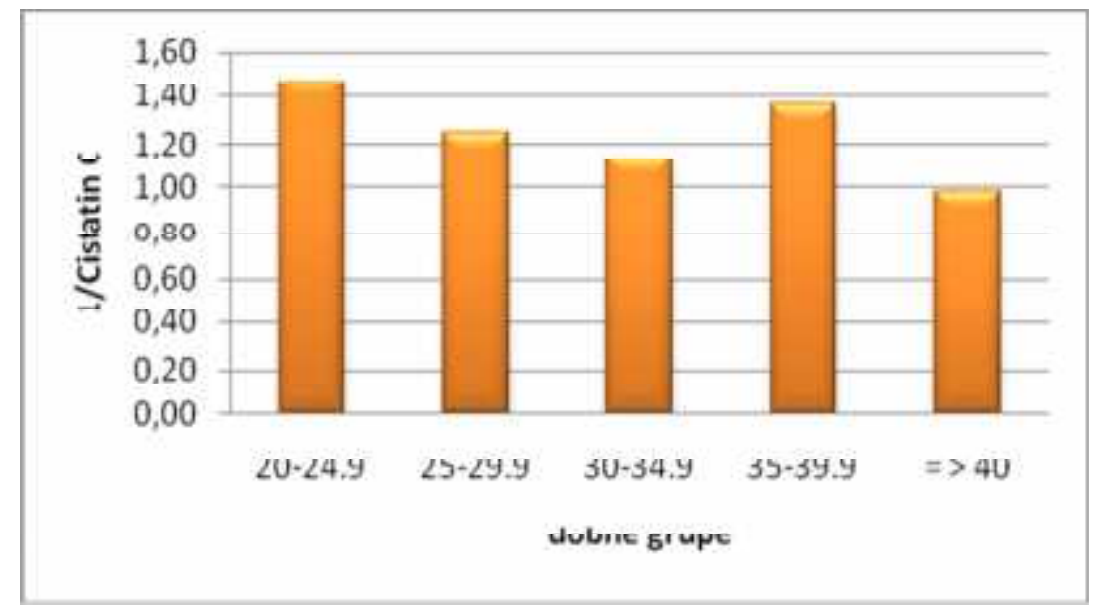

Slika 28. Vrednosti 1/cistatin C u odnosu na životnu dob trudnica

LSD testiranje je pokazalo da su recipročne vrednosti cistatina $\mathrm{C}$ trudnica koje su starije od 40 godina statistički značajno niže $(\mathrm{p}<0,01)$ u odnosu na dobne grupe $20-24,9$ i 35-39,9 godina (Tabela 36).

Tabela 36. LSD testiranje prosečnih recipročnih vrednosti cistatina $\mathrm{C}$ među dobim grupama trudnica

\begin{tabular}{|c|c|c|c|c|c|}
\hline \multicolumn{6}{|c|}{ 1/Cistatin C } \\
\hline \multirow{2}{*}{$\begin{array}{l}\text { Dobne } \\
\text { grupe }\end{array}$} & \multirow{2}{*}{$\begin{array}{l}\text { Dobne } \\
\text { grupe }\end{array}$} & \multirow{2}{*}{$\begin{array}{c}\text { Srednja } \\
\text { razlika } \\
\text { među } \\
\text { grupama }\end{array}$} & \multirow{2}{*}{ Sig. } & \multicolumn{2}{|c|}{$95 \%$ interval pouzdanosti } \\
\hline & & & & $\begin{array}{l}\text { Donja } \\
\text { granica }\end{array}$ & $\begin{array}{l}\text { Gornja } \\
\text { granica }\end{array}$ \\
\hline \multirow[t]{4}{*}{$20-24,9$} & $25-29,9$ & 0,227658 & 0,09 & $-0,0351377$ & 0,49045384 \\
\hline & $30-34,9$ & 0,341965 & 0,01 & 0,0714219 & 0,61250791 \\
\hline & $35-39,9$ & 0,110166 & 0,42 & $-0,1586176$ & 0,37894992 \\
\hline & $=>40$ & 0,487704 & 0,00 & 0,1588771 & 0,81652988 \\
\hline \multirow[t]{4}{*}{$25-29,9$} & $20-24,9$ & $-0,22766$ & 0,09 & $-0,4904538$ & 0,03513774 \\
\hline & $30-34,9$ & 0,114307 & 0,30 & $-0,1027267$ & 0,33134042 \\
\hline & $35-39,9$ & $-0,11749$ & 0,28 & $-0,3323285$ & 0,0973447 \\
\hline & $=>40$ & 0,260045 & 0,07 & $-0,0263753$ & 0,54646619 \\
\hline \multirow[t]{4}{*}{$30-34,9$} & $20-24,9$ & $-0,34196$ & 0,01 & $-0,6125079$ & $-0,0714219$ \\
\hline & $25-29,9$ & $-0,11431$ & 0,30 & $-0,3313404$ & 0,10272672 \\
\hline & $35-39,9$ & $-0,2318$ & 0,04 & $-0,4560456$ & $-0,0075519$ \\
\hline & $=>40$ & 0,145739 & 0,33 & $-0,1478065$ & 0,43928371 \\
\hline \multirow[t]{4}{*}{$35-39,9$} & $20-24,9$ & $-0,11017$ & 0,42 & $-0,3789499$ & 0,15861762 \\
\hline & $25-29,9$ & 0,117492 & 0,28 & $-0,0973447$ & 0,3323285 \\
\hline & $30-34,9$ & 0,231799 & 0,04 & 0,0075519 & 0,45604562 \\
\hline & $=>40$ & 0,377537 & 0,01 & 0,0856128 & 0,66946188 \\
\hline \multirow[t]{4}{*}{$=>40$} & $20-24,9$ & $-0,4877$ & 0,00 & $-0,8165299$ & $-0,1588771$ \\
\hline & $25-29,9$ & $-0,26005$ & 0,07 & $-0,5464662$ & 0,02637529 \\
\hline & $30-34,9$ & $-0,14574$ & 0,33 & $-0,4392837$ & 0,14780651 \\
\hline & $35-39,9$ & $-0,37754$ & 0,01 & $-0,6694619$ & $-0,0856128$ \\
\hline
\end{tabular}


Grupa od 30-34,9 godina ima statistički značajno nižu $(\mathrm{p}<0,01)$ recipročnu vrednosti cistatina C u odnosu na grupu 20-24,9 i 35-39,9 godina (Tabela 36).

\subsubsection{Distribucija cistatina $C$ i drugih određivanih parametara u odnosu na trimestar i dobne grupe}

Da bi utvrdili odnos životne dobi i gestacionog perioda trudnice su razvrstane po trimestrima i u okviru svakog trimestra su dodatno razvrstane na dobne grupe koje su obuhvatale petogodišnji period. U prvom trimestru nije bilo trudnica starijih od 40 godina.

\subsubsection{Distribucija vrednosti cistatina $C$ zavisno od trimestra i dobne grupe trudnica}

Najviša vrednost cistatina $\mathrm{C}$ u I trimestru je bila $0,74 \pm 0,12 \mathrm{mg} 1 \mathrm{u}$ dobnoj grupi 25-29,9 godina dok je najniža bila $0,59 \pm 0,03 \mathrm{mg} 1 \mathrm{u}$ dobnoj grupi 35-39,9 godina, (Tabela 37).

Tabela 37. Distribucija vrednosti cistatina $\mathrm{C}$ zavisno od trimestra i dobne grupe

\begin{tabular}{|c|l|c|c|c|c|c|c|c|c|c|}
\hline & \multirow{2}{*}{$\begin{array}{l}\text { Starosna } \\
\text { dob-godine }\end{array}$} & \multicolumn{3}{|c|}{ I TRIMESTAR } & \multicolumn{3}{|c|}{ II TRIMESTAR } & \multicolumn{3}{|c|}{ III TRIMESTAR } \\
\cline { 3 - 11 } & $\mathrm{N}$ & $\overline{\mathbf{x}}$ & $\mathrm{SD}$ & $\mathrm{N}$ & $\overline{\mathbf{x}}$ & $\mathrm{SD}$ & $\mathrm{N}$ & $\overline{\mathbf{x}}$ & $\mathrm{SD}$ \\
\hline \multirow{4}{*}{$\begin{array}{c}\text { cistatin C } \\
(\mathbf{m g} / \mathbf{l})\end{array}$} & $20-24,9$ & 4 & 0,61 & 0,30 & 4 & 0,64 & 0,07 & 6 & 1,03 & 0,32 \\
\cline { 2 - 11 } & $25-29,9$ & 18 & 0,74 & 0,12 & 4 & 0,75 & 0,14 & 9 & 1,17 & 0,32 \\
\cline { 2 - 11 } & $30-34,9$ & 8 & 0,72 & 0,18 & 5 & 0,79 & 0,38 & 13 & 1,28 & 0,26 \\
\cline { 2 - 11 } & $35-39,9$ & 8 & 0,59 & 0,03 & 13 & 0,73 & 0,09 & 6 & 1,21 & 0,28 \\
\cline { 2 - 11 } & $=>40$ & & & & 6 & 0,99 & 0,43 & 5 & 1,35 & 0,38 \\
\cline { 2 - 11 } & Ukupno & $\mathbf{3 8}$ & $\mathbf{0 , 6 9}$ & $\mathbf{0 , 1 6}$ & $\mathbf{3 2}$ & $\mathbf{0 , 7 8}$ & $\mathbf{0 , 2 6}$ & $\mathbf{3 9}$ & $\mathbf{1 , 2 1}$ & $\mathbf{0 , 3 0}$ \\
\hline
\end{tabular}

ANOVA testom nije utvrđena statistički značajna razlika cistatina $\mathrm{C}$ zavisno od dobne grupe kod trudnica $\mathrm{u}$ I trimestru $(\mathrm{F}=2,50 \mathrm{p}=0,076)$ ali je dodatno LSD testiranje pokazalo da je unutar I trimestra cistatin $C$ statistički značajno viši $(\mathrm{p}<0,05)$ u dobnoj grupi 25-29,9 godina u odnosu na dobnu grupu 35-39,9 godina (Slika 29). 
U II trimestru najviša vrednost cistatina $\mathrm{C}$ je bila $0,99 \pm 0,43 \mathrm{mg} 1 \mathrm{u}$ najstarijoj dobnoj grupi dok je najniža bila $0,64 \pm 0,07 \mathrm{mg} 1 \mathrm{u}$ dobnoj grupi 20-24,9 godina.

ANOVA testom nije dokazana statistički značajna razlika cistatina $\mathrm{C}$ u odnosu na dobnu grupu trudnica $(\mathrm{F}=1,577 \mathrm{p}=0,209)$, dok je precizniji LSD test pokazao da je cistatin $\mathrm{C}$ u dobnoj grupi $=>40$ godina statistički značajno viši $(\mathrm{p}<0,05)$ u odnosu na dobne grupe 20-24,9 godina i 35-39,9 godina trudnica II trimestra (Slika 29).

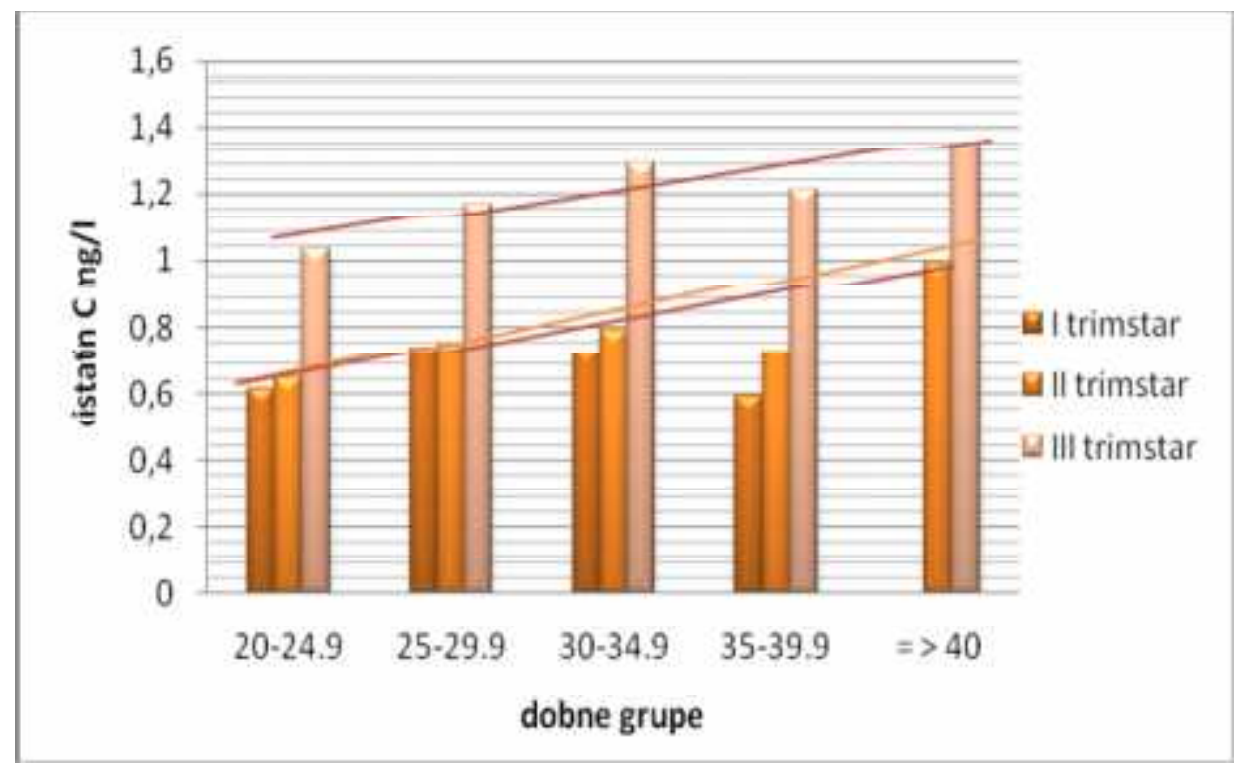

Slika 29. Zavisnost cistatina $\mathrm{C}$ od životne dobi i trimestra trudnoće

U III trimestru najviša vrednost cistatina $C$ je bila $1,35 \pm 0,38 \mathrm{mg} 1 \mathrm{u}$ najstarijoj dobnoj grupi dok je najniža bila 1,03 $\pm 0,32 \mathrm{mg} 1 \mathrm{u}$ dobnoj grupi 20-24,9 godina.

Slično kao u prva dva trimestra i u trećem trimestru ANOVA testom nije dokazana statistički značajna razlika cistatina $\mathrm{C} u$ odnosu na starost trudnica $(F=1,014 \mathrm{p}=0,414)$, što je potvrđeno i dodatnim LSD testiranjem.

Poređenjem dobnih grupa dokazana je statistički značajna razlika vrednosti cistatina C u starosnoj dobi 35-40 godina između I i II trimestra, kada cistatin C značajno raste $(p<0,05)$. Između II i III trimestra postoji statistički značajna razlika vrednosti cistatina $\mathrm{C}$ u svim dobnim grupama $(\mathrm{p}<0,05)($ Slika 29).

Dokazano je da postoji statistički značajna razlika cistatina $\mathrm{C}$ u svim dobnim grupama između I i III trimestra $(\mathrm{p}<0,05)$.

Prosečne vrednosti cistatina $\mathrm{C}$ imaju trend rasta $\mathrm{u}$ prvom, drugom i trećem trimestru prema dobnim grupama, odnosno sa starošću raste prosečna vrednost cistatina C (Slika 29). 


\subsubsection{Distribucija recipročnih vrednosti cistatina $C$ zavisno od trimestra i dobne grupe}

$\mathrm{U}$ I trimestru najviše recipročne vrednosti cistatina $\mathrm{C}$ su bile kod trudnica u dobi od 20-25,9 godina i iznosile su u proseku 2,01 \pm 0,10 a najniže u dobi od 25 do 29,9 godina starosti i iznosile su u proseku 1,38 \pm 0,21 i bile su visoko statistički značajno niže u odnosu na grupu od 20-25,9 godina $(\mathrm{p}<0,005)$ (Tabela 38$)$.

$\mathrm{U}$ II trimestru najviše recipročne vrednosti cistatina $\mathrm{C}$ su bile kod trudnica u dobi od 20 do 24,9 godina i iznosile su u proseku 1,59 $\pm 0,19$, dok su najniže bile u dobi preko 40 godina i iznosile su u proseku 1,15 $\pm 0,44$, a LSD testom je dokazano da je ova recipročna vrednost cistatina $\mathrm{C}$ bila statistički značajno niža $(p<0,05)$.

Tabela 38. Distribucija recipročnih vrednosti cistatina $\mathrm{C}$ zavisno od trimestra i dobne grupe

\begin{tabular}{|c|c|c|c|c|c|c|c|c|c|c|}
\hline & \multirow{2}{*}{$\begin{array}{l}\text { Starosna } \\
\text { dob-godine }\end{array}$} & \multicolumn{3}{|c|}{ I TRIMESTAR } & \multicolumn{3}{|c|}{ II TRIMESTAR } & \multicolumn{3}{|c|}{ III TRIMESTAR } \\
\hline & & $\mathrm{N}$ & $\overline{\mathbf{x}}$ & SD & $\mathrm{N}$ & $\overline{\mathbf{x}}$ & SD & $\mathrm{N}$ & $\overline{\mathbf{x}}$ & SD. \\
\hline \multirow{6}{*}{$\begin{array}{c}1 / \\
\text { cistatin } C\end{array}$} & $20-24,9$ & 4 & 2,01 & 0,99 & 4 & 1,59 & 0,19 & 6 & 1,04 & 0,27 \\
\hline & $25-29,9$ & 18 & 1,38 & 0,21 & 4 & 1,38 & 0,27 & 9 & 0,91 & 0,24 \\
\hline & $30-34,9$ & 8 & 1,46 & 0,34 & 5 & 1,43 & 0,44 & 13 & 0,81 & 0,15 \\
\hline & $35-39,9$ & 8 & 1,71 & 0,10 & 13 & 1,38 & 0,16 & 6 & 0,87 & 0,22 \\
\hline & $=>40$ & & & & 6 & 1,15 & 0,44 & 5 & 0,78 & 0,19 \\
\hline & Ukupno & 38 & 1,53 & 0,41 & 32 & 1,37 & 0,30 & 39 & 0,87 & 0,21 \\
\hline
\end{tabular}

U III trimestru najviše recipročne vrednosti cistatina $\mathrm{C}$ su bile kod trudnica u dobi od 20 do 24,9 godina i iznosile su u proseku 1,04 $\pm 0,27$ dok su najniže bile u dobi preko 40 godina i iznosile su u proseku $0,78 \pm 0,19$. LSD testom je dokazano da je recipročna vrednost cistatina $\mathrm{C}$ trudnica dobne grupe 20 do 24,9 godina bila statistički značajno viša u odnosu na dobne grupe 30-34,9 godina i dobnu grupu preko 40 $(\mathrm{p}<0,05)$.

Postoji statistički značajna razlika $(\mathrm{p}<0,05)$ 1/cistatina C između I i II trimestra, u starosnoj dobi 35 - 40 godina, kada 1/cistatin C značajno opada.

Postoji statistički značajna razlika $(p<0,05) 1$ /cistatina $\mathrm{C}$ između II i III trimestra $u$ svim dobnim grupama. Takođe i između I i III trimestra je dokazana statistički značajna razlika $(\mathrm{p}<0,05) 1 /$ cistatina $\mathrm{C}$ u svim dobnim grupama (Tabela 38$)$.

Prosečne recipročne vrednosti cistatina $\mathrm{C}$ u svim trimestrima imale su sa starošću trend opadanja (Slika 30). 


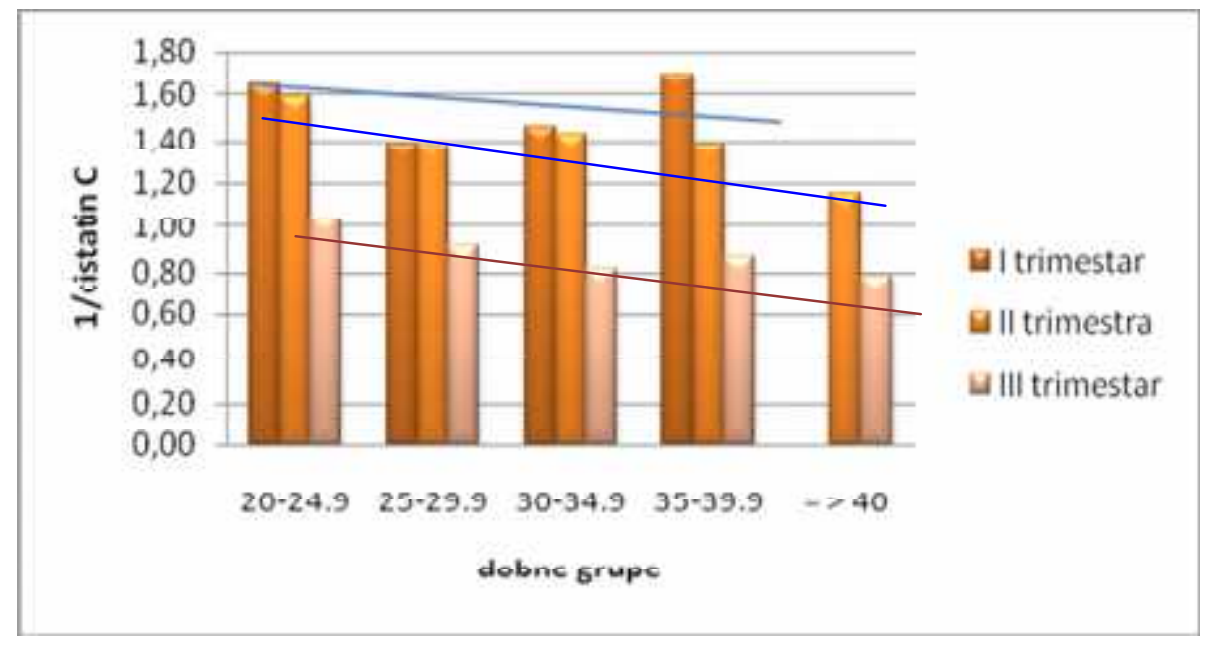

Slika 30. Recipročna vrednost cistatin $\mathrm{C}$ prema dobnim grupama i trimestrima

\subsubsection{Distribucija koncentracija kreatinina zavisno od trimestra i dobne grupe}

Najviša prosečna koncentraciju kreatinina u I trimestru je bila 63,25 $\mu \mathrm{mol} / 1 \mathrm{u}$ dobnoj grupi 30-34,9 godina, a najniža je bila 55,75 $\mu \mathrm{mol} / 1$ u dobnoj grupi 35-39,9 godina (Tabela 39).

ANOVA testom nije utvrđena statistički značajna razlika koncentracije kreatinina zavisno od dobne grupe kod trudnica $\mathrm{u}$ I trimestru $(\mathrm{F}=1,86 \mathrm{p}=0,163)$ ali je dodatno LSD testiranje pokazalo da se unutar I trimestra koncentracija kreatinina statistički značajno razlikuje u dobnoj grupi 30-34,9 godina u odnosu na dobnu grupu 35-39,9 godina $(\mathrm{p}<0,05)$.

U II trimestru najviša prosečna vrednost kreatinina je bila 70,67 $\mu \mathrm{mol} / 1 \mathrm{u}$ najstarijoj dobnoj grupi dok je najniža bila $64,00 \mu \mathrm{mol} / 1 \mathrm{u}$ dobnoj grupi 30-34,9 godina.

ANOVA testom nije dokazana statistički značajna razlika koncentracije kreatinina $\mathrm{u}$ odnosu na dobnu grupu trudnica $(\mathrm{F}=0,313 \mathrm{p}=0,867)$. Ni preciznijim LSD testom nije utvrđena statistički značajna razlika među grupama u II trimestru trudnoće.

U III trimestru najviša prosečna vrednost kreatinina je bila 75,00 $\mu \mathrm{mol} / 1 \mathrm{u}$ dobnoj grupi preko 40 godina dok je najniža prosečna vrednost bila $61,17 \mu \mathrm{mol} / 1 \mathrm{u}$ dobnoj grupi 20-24,9 godina. ANOVA testom nije dokazana statistički značajna razlika koncentracije kreatinina u odnosu na dobnu grupu trudnica u III trimestru $(\mathrm{F}=2,162$ $\mathrm{p}=0,094)$. 
Tabela 39. Distribucija koncentracija kreatinina zavisno od trimestra i dobne grupe trudnica

\begin{tabular}{|c|c|c|c|c|c|c|c|c|c|c|}
\hline & \multirow{2}{*}{$\begin{array}{c}\text { Starosna } \\
\text { dob, } \\
\text { godine }\end{array}$} & \multicolumn{3}{|c|}{ I TRIMESTAR } & \multicolumn{3}{|c|}{ II TRIMESTAR } & \multicolumn{3}{|c|}{ III TRIMESTAR } \\
\hline & & $\mathrm{N}$ & $\overline{\mathbf{x}}$ & SD & $\mathrm{N}$ & $\overline{\mathbf{x}}$ & SD & $\mathrm{N}$ & $\overline{\mathbf{x}}$ & SD \\
\hline \multirow{6}{*}{$\begin{array}{c}\text { Kreatinin } \\
\text { u serumu } \\
(\mu \mathrm{mol} / \mathrm{l})\end{array}$} & $20-24,9$ & 4 & 58,50 & 9,81 & 4 & 68,00 & 10,23 & 6 & 61,17 & 11,25 \\
\hline & $25-29,9$ & 18 & 58,89 & 8,04 & 4 & 65,50 & 15,55 & 9 & 67,89 & 7,80 \\
\hline & $30-34,9$ & 8 & 63,25 & 2,31 & 5 & 64,00 & 12,63 & 13 & 62,92 & 5,28 \\
\hline & $35-39,9$ & 8 & 55,75 & 1,16 & 13 & 64,23 & 13,53 & 6 & 65,17 & 12,67 \\
\hline & $=>40$ & & & & 6 & 70,67 & 11,15 & 5 & 75,00 & 11,16 \\
\hline & Total & 38 & 59,11 & 6,71 & 32 & 66,03 & 12,32 & 39 & 65,69 & $\mathbf{9 , 5 4}$ \\
\hline
\end{tabular}

Preciznijim LSD testom utvrđeno je da su prosečne vrednosti kreatinina najstarijih turdnica, preko 40 godina, statistički značajno više u odnosu na grupe 30-34,9 godina i 20-24,9 godina $(\mathrm{p}<0,05)$.

Statistički značajno različite $(\mathrm{p}<0,05)$ prosečne vrednosti kreatinina u serumu su uočene kod trudnica koje pripadaju životnoj dobi od 20-24,9 godina prvog trimestra u odnosu na trudnice iste životne dobi drugog trimestra.

U sva tri trimestra vrednosti kreatinina imale su trend rasta (Slika 31).

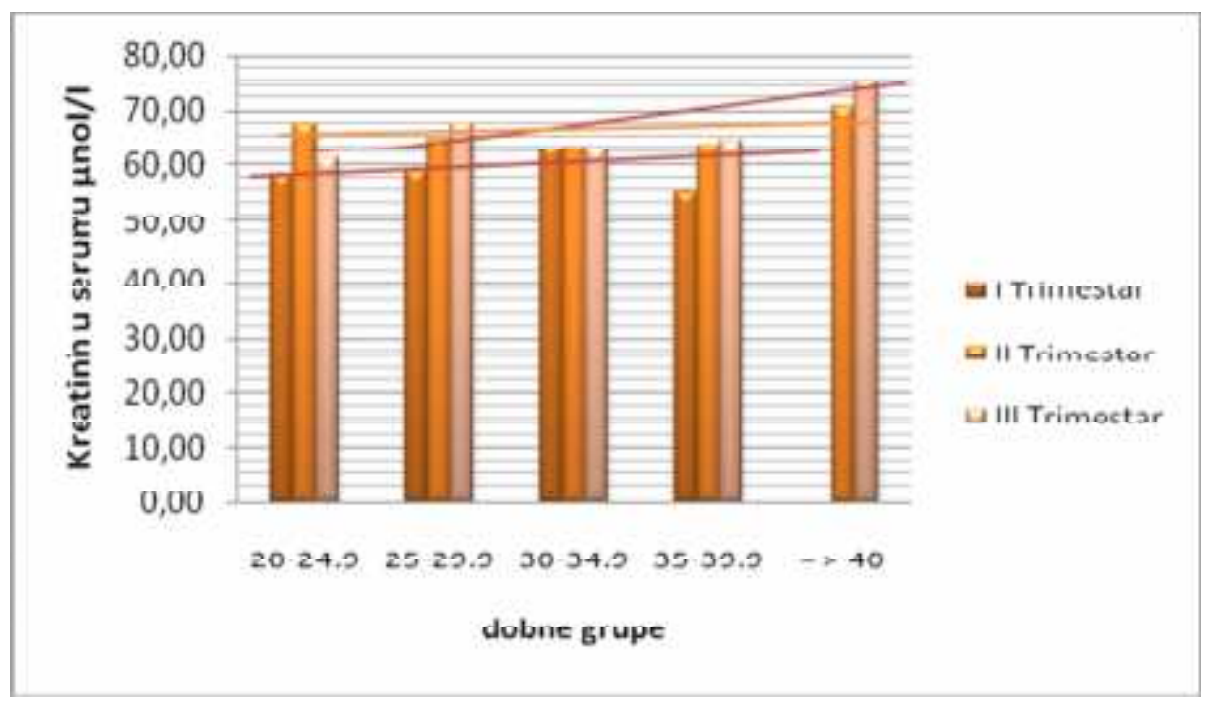

Slika 31. Kreatinin u serumu zavisno od trimestra i životne dobi trudnica 


\subsubsection{Distribucija klirensa kreatinina zavisno od trimestra i dobne grupe trudnica}

U prvom trimestru trudnoće najviše vrednosti klirensa kreatinina zabeležene su kod trudnica u dobi od 35-39,9 godina i iznosile su u proseku 126,6 $\pm 15,04 \mathrm{ml} / \mathrm{min}$, a najniže u dobi od 30-34,9 godina starosti i iznosile su u proseku 100,2 $\pm 14,9 \mathrm{ml} / \mathrm{min}$, (Tabela 40).

U ovom trimestru vrednosti klirensa kreatinina su bile visoko statistički značajno više u dobnoj grupi 35-39,9 godina od vrednosti u dobnoj grupi 30-35 godina i 25-29,9 godina $(\mathrm{p}<0,0005)$ i u dobnoj grupi 20-24,9 $(\mathrm{p}<0,005)$.

Tabela 40. Distribucija klirensa kreatinina zavisno od trimestra i dobne grupe trudnica

\begin{tabular}{|c|c|c|c|c|c|c|c|c|c|c|}
\hline & \multirow{2}{*}{$\begin{array}{c}\text { Starosna } \\
\text { dob } \\
\text { godine }\end{array}$} & \multicolumn{3}{|c|}{ I TRIMESTAR } & \multicolumn{3}{c|}{ II TRIMESTAR } & \multicolumn{3}{|c|}{ III TRIMESTAR } \\
\cline { 3 - 12 } & $20-24,9$ & 4 & $\overline{\mathrm{x}}$ & $\mathrm{SD}$ & $\mathrm{N}$ & $\overline{\mathbf{x}}$ & $\mathrm{SD}$ & $\mathrm{N}$ & $\overline{\mathbf{x}}$ & $\mathrm{SD}$ \\
\hline \multirow{4}{*}{$\begin{array}{c}\text { Klirens } \\
\text { kreatinina } \\
\text { ml/min }\end{array}$} & $25-29,9$ & 18 & 101,27 & 10,39 & 4 & 91,80 & 16,81 & 9 & 95,80 & 15,68 \\
\cline { 2 - 12 } & $30-34,9$ & 8 & 100,20 & 14,90 & 5 & 106,20 & 14,26 & 13 & 117,46 & 19,74 \\
\cline { 2 - 12 } & $35-39,9$ & 8 & 126,60 & 15,04 & 13 & 102,14 & 16,13 & 6 & 114,50 & 13,06 \\
\cline { 2 - 11 } & $=>40$ & & & & 6 & 116,30 & 37,29 & 5 & 98,76 & 30,70 \\
\cline { 2 - 11 } & Ukupno & 38 & 106,61 & 15,69 & 32 & 106,99 & 24,50 & 39 & 107,69 & 19,91 \\
\hline
\end{tabular}

U drugom trimestru trudnoće najviše vrednosti klirensa kreatinina zabeležene su kod trudnica u dobi od 20-24,9 godina i iznosile su u proseku 124,95 $\pm 35,77 \mathrm{ml} / \mathrm{min}$, a najniže u dobi od 25-29,9 godina starosti i iznosile su u proseku 91,8 $\pm 16,81 \mathrm{ml} / \mathrm{min}$, (Tabela 40).

$\mathrm{U}$ ovom trimestru nije nađena statistički značajna razlika vrednosti klirensa kreatinina između dobnih grupa ni ANOVA ni LSD testiranjem.

U trećem trimestru trudnoće najviše vrednosti klirensa kreatinina zabeležene su kod trudnica u dobi od 30-34,9 godina i iznosile su u proseku 114,5 $\pm 13,06 \mathrm{ml} / \mathrm{min}$, a najniže u dobi od 25-29,9 godina starosti i iznosile su u proseku 95,8 $\pm 15,68 \mathrm{ml} / \mathrm{min}$, (Tabela 40).

U ovom trimestru ANOVA testom nije nađena statistički značajna razlika vrednosti klirensa kreatinina između dobnih grupa, a LSD testom je utvrđeno da su 
statistički značajno niže vrednosti $(\mathrm{p}<0,05)$ klirensa kreatinina u grupi $25-29,9$ prema grupi 30-34,9 godina.

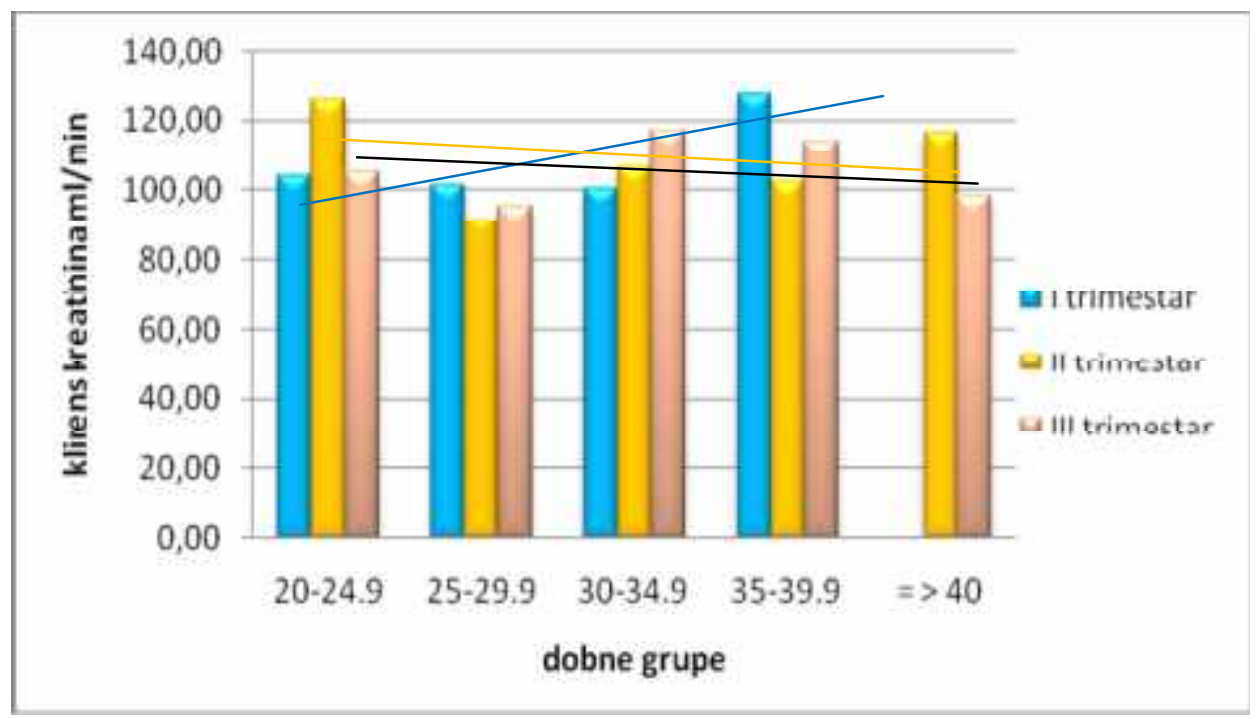

Slika 32. Prosečna vrednost klirensa kreatinina prema trimestrima i životnoj dobi trudnica

U starosnoj dobi 35-39,9 godina nivoi klirensa kreatinina se statistički značajno razlikuju $(\mathrm{p}<0,05)$ između I i II trimestra kao i između I i III trimestra klirens kreatinina značajno opada $(\mathrm{p}<0,05)$.

Prosečne vrednosti klirensa kreatinina prema dobnim grupama $u$ drugom i $u$ trećem trimestru imale su trend opadanja, dok su u prvom trimestru imale trend rasta, odnosno sa starenjem u prvom trimestru rastu prosečne vrednosti klirensa kreatinin (Slika 32). 


\subsection{REZULTATI ODREĐIVANJA KREATININA, KLIRENSA KREATININA I CISTATINA C KOD TRUDNICA SA PIH}

Kako je hipertenzija moguća prateća komplikacija trudnoće jedan od ciljeva ovog rada je bio da se odredi cistatin $\mathrm{C}$ kod 33 trudnice koje su u trećem trimestru imale hipertenziju izazvanu trudnoćom (PIH) i da se utvrdi da li kod njih cistatin C može da bude dobar pokazatelj JGF. Prosečna starost trudnica je bila 28,91 $\pm 6,1$ godinu. Najmlađa trudnica je imala 20 godina dok je najstarija imala 44 godina.

4.3.1. Distribucija vrednosti kreatinina, klirensa kreatinina, cistatina $C i$ recipročne vrednosti cistatina $\mathrm{C}$ kod trudnica sa PIH

Prosečna koncentracija kreatinina u serumu ispitivanih trudnica sa PIH bila je $65,27 \pm 10,62 \mu \mathrm{mol} / 1$, dok je prosečna vrednost klirensa kreatinina bila 103,05 $\mathrm{ml} / \mathrm{min}$, (Tabela 41).

Tabela 41. Distribucija vrednosti kreatinina, klirensa kreatinina, cistatina $\mathrm{C}$ i recipročne vrednosti cistatina $\mathrm{C}$ kod trudnica sa $\mathrm{PIH}$

\begin{tabular}{|c|c|c|c|c|c|c|}
\hline \multirow[b]{2}{*}{ Parametar } & \multirow[b]{2}{*}{$\overline{\mathbf{x}}$} & \multirow[b]{2}{*}{$\mathrm{SD}$} & \multicolumn{2}{|c|}{$95 \%$ Granica pouzdanosti } & \multirow[b]{2}{*}{ Min. } & \multirow[b]{2}{*}{ Maks. } \\
\hline & & & $\begin{array}{l}\text { Donja } \\
\text { granica }\end{array}$ & $\begin{array}{l}\text { Gornja } \\
\text { granica }\end{array}$ & & \\
\hline Kreatinin u serumu $(\mu \mathrm{mol} / \mathrm{l})$ & 65,27 & 10,62 & 61,51 & 69,04 & 46 & 96 \\
\hline Klirens kreatinina ( $\mathrm{ml} / \mathrm{min})$ & 103,05 & 24,61 & 94,33 & 111,78 & 60 & 153,6 \\
\hline Cistatin C (mg/l) & 1,45 & 0,43 & 1,30 & 1,61 & 0,86 & 2,54 \\
\hline 1/cistatin $C$ & 0,74 & 0,20 & 0,67 & 0,81 & 0,39 & 1,16 \\
\hline
\end{tabular}

Prosečni nivo cistatina $\mathrm{C}$ iznosio je 1,45 \pm 0,43 $\mathrm{mg} / 1$ dok je prosečna recipročna vrednost cistatina $\mathrm{C}$ kod trudnica kojima je dijagnostikovan PIH bila 0,74 $\pm 0,20$. 


\subsubsection{Međusobna korelacija nivoa kreatinina, klirensa kreatinina, cistatina $\mathbf{C} i$ recipročne vrednosti cistatina $\mathrm{C}$ dobijenih kod trudnica sa PIH}

Kod trudnica sa PIH koncentracija kreatinina u serumu obrnuto korelira, statistički značajno sa nivoom klirensa kreatinina $(\mathrm{p}<0,017)$, sa porastom kreatinina $\mathrm{u}$ serumu statistički značajno najčešće opada nivo klirens kreatinina (Tabela 42).

Kod trudnica sa PIH vrednosti kreatinina u serumu direktno statistički neznačajno koreliraju sa vrednostima cistatina $\mathrm{C}$, dok klirens kreatinina obrnuto statistički neznačajno korelira sa cistatinom $\mathrm{C}$ i direktno statistički neznačajno korelira sa 1/cistatin C. Nije potvrđena veza između cistatina $\mathrm{C}$ i kreatinina, ni između cistatina $\mathrm{C}$ i klirensa kreatinina.

Tabela 42. Korelacija kreatinina, klirensa kreatinina, cistatina C i 1/cistatin C kod trudnica sa PIH

\begin{tabular}{|c|c|c|c|c|c|}
\hline & & $\begin{array}{c}\text { Kreatinin } \\
\text { u serumu } \\
\mu \mathrm{mol} / 1\end{array}$ & $\begin{array}{c}\text { Klirens } \\
\text { kreatinina } \\
\mathrm{ml} / \mathrm{min} \\
\end{array}$ & 1/cistatin C & $\underset{\mathrm{mg} / \mathrm{l}}{\operatorname{cistatin} \mathbf{C}}$ \\
\hline \multirow{3}{*}{$\begin{array}{c}\text { Kreatinin u } \\
\text { serumu } \\
\mu \mathrm{mol} / 1\end{array}$} & R koef. & 1 & $-0,406(*)$ & $-0,214$ & 0,276 \\
\hline & Sig. (p) & . & 0,017 & 0,225 & 0,114 \\
\hline & $\mathrm{N}$ & 34 & 34 & 34 & 34 \\
\hline \multirow{3}{*}{$\begin{array}{c}\text { Klirens } \\
\text { kreatinina } \\
\mathrm{ml} / \mathrm{min}\end{array}$} & R koef. & $-0,406\left(^{*}\right)$ & 1 & 0,014 & $-0,124$ \\
\hline & Sig. (p) & 0,017 & . & 0,935 & 0,485 \\
\hline & $\mathrm{N}$ & 34 & 34 & 34 & 34 \\
\hline \multirow{3}{*}{$\underset{\mathrm{mg} / \mathrm{l}}{\mathbf{C i s t a t i n} \mathbf{C}}$} & R koef. & 0,276 & $-0,124$ & $-0,963(* *)$ & 1 \\
\hline & Sig. (p) & 0,114 & 0,485 & 0,000 & . \\
\hline & $\mathrm{N}$ & 34 & 34 & 34 & 34 \\
\hline \multirow{3}{*}{ 1/cistatin C } & R koef. & $-0,214$ & 0,014 & 1 & $-0,963(* *)$ \\
\hline & Sig. (p) & 0,225 & 0,935 & . & 0,000 \\
\hline & $\mathrm{N}$ & 34 & 34 & 34 & 34 \\
\hline
\end{tabular}

$* \mathrm{p}<0,05$ postoji značajna korelacija među parametrima

$* * \mathrm{p}<0,01$ postoji značajna korelacija među parametrima

\subsubsection{Korelacija nivoa kreatinina, klirensa kreatinina, cistatina $\mathrm{C}$ i recipročne vrednosti cistatina $\mathrm{C}$ trudnica sa PIH prema nivoima zdravih trudnica u III trimestru}

Ranije smo utvrdili da se cistatin C statistički značajno menja zavisno od gestacionog perioda. Zato nam je bio cilj da ustanovimo kakvo je slaganje između posmatranih parametara dobijenih za trudnice sa PIH prema vrednostima dobijenim kod 
zdravih trudnica u III trimestru. Izračunati su korelacioni koeficijenti za sve parametre (Tabela 43).

Tabela 43. Korelacija kreatinina, klirensa kreatinina, cistatina $C$ i recipročne vrenosti cistatina $\mathrm{C}$ kod trudnica sa PIH u odnosu na trudnice III trimestra

\begin{tabular}{|c|c|c|}
\hline & $\mathrm{F}$ & Sig. \\
\hline Kreatinin u serumu & 0,115 & 0,736 \\
\hline Klirens kreatinina & 1,147 & 0,288 \\
\hline Cistatin C & 9,089 & $0,004^{* *}$ \\
\hline 1/cistatin C & 8,040 & $0,006^{* *}$ \\
\hline
\end{tabular}

Testom ANOVA dobijeni faktori korelacije pokazuju da su trudnice sa PIH imale vrednosti cistatina $C$ statistički značajno više $(F=9,089 \mathrm{p}<0,004)$, a recipročne vrednosti cistatina $\mathrm{C}$ statistički značajno niže $(\mathrm{F}=8,040 \mathrm{p}<0,006) \mathrm{u}$ odnosu na zdrave trudnice u III trimestru. Ne postoji statistički značajna razlika vrednosti kreatinina i klirensa kreatinina kod trudnica sa PIH u odnosu na zdrave trudnice u III trimestru.

\subsubsection{Receiver Operating Characteristic Curve kod trudnica sa PIH u odnosu na III trimester}

U Tabeli 44. su prikazane karakteristike krivih odabranih parametara kod trudnica III trimestra u odnosu na trudnice sa PIH.

Tabela 44. Podaci iz ROC analize za vrednosti kreatinina, klirensa kreatinina, cistatina $\mathrm{C}$ i recipročne vrednosti cistatina $\mathrm{C}$

\begin{tabular}{c|c|c|c|c|c}
\hline \multirow{2}{*}{ Test Result Variable } & \multirow{2}{*}{ AUC } & \multirow{2}{*}{ SE } & \multirow{2}{*}{$\begin{array}{c}\text { Asymptotic } \\
\text { Sig. }\end{array}$} & \multicolumn{2}{|c}{$95 \%$ C I } \\
\cline { 5 - 6 } & & & Donja & Gornja \\
\hline Kreatinin & 0,491 & 0,069 & 0,894 & 0,356 & 0,626 \\
\hline Klirens kreatinina & 0,541 & 0,071 & 0,547 & 0,401 & 0,681 \\
\hline Cistatin C & 0,321 & 0,063 & $0,008^{* * *}$ & 0,197 & 0,444 \\
\hline 1/cistatin C & 0,678 & 0,063 & $0,009^{* * *}$ & 0,555 & 0,802 \\
\hline
\end{tabular}

Vrednosti cistatina C $(0,321 \mathrm{p}<0,008)$, kao i $1 /$ cistatin $C(0,679 \mathrm{p}<0,009)$, pod ROC krivom imaju statistički značajnu površinu dok krive za vrednosti kreatinina $(0,491)$ i klirensa kreatinina $(0,541)$ nemaju statistički značajnu površinu (Slika 33$)$. 


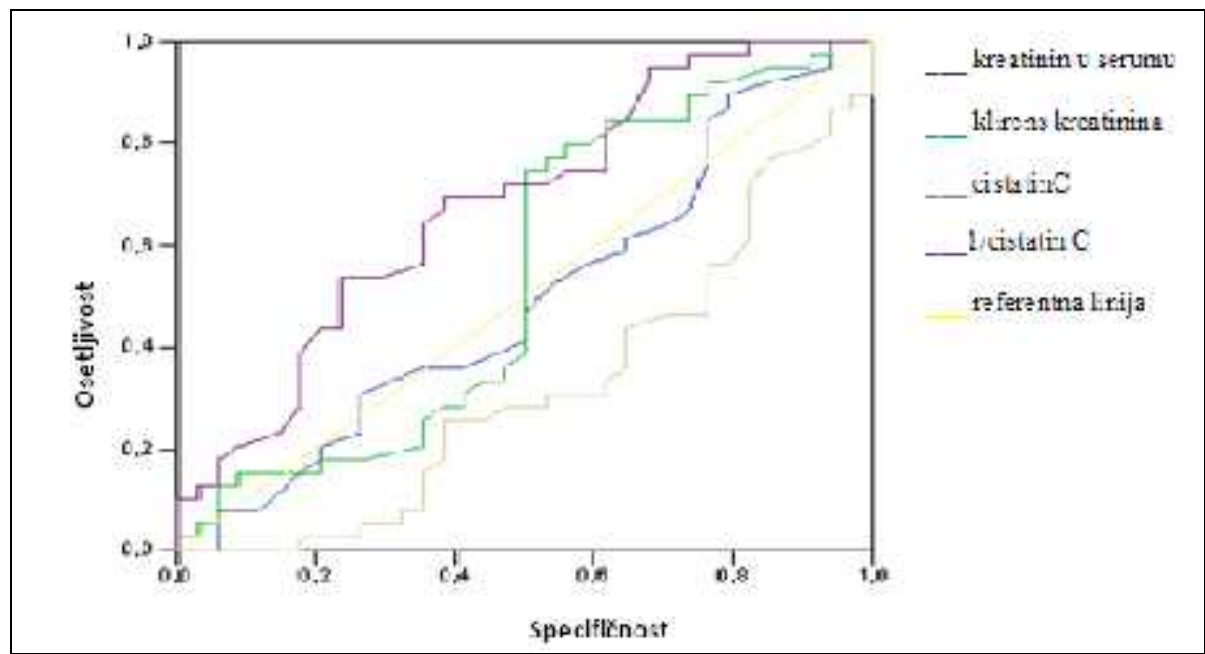

Slika 33. ROC grafik posmatranih parametara

\subsubsection{Prosečne vrednosti klirensa kreatinina, kreatinina i cistatina $\mathrm{C}$ kod trudnica sa PIH u odnosu na životnu dob}

U cilju ispitivanja kako životna dob trudnica sa PIH utiče na vednosti kreatinina, klirensa kreatinina, cistatina $\mathrm{C}$ i recipročnu vrednost cistatina $\mathrm{C}$, trudnice su grupisane $\mathrm{u}$ odnosu na starost u četiri dobne grupe. Svaka dobna grupa obuhvata petogodišnji period. Prvu dobnu grupu činilo je 7 trudica životne dobi od 20 do 24,9 godina. Drugu dobnu grupu su činile trudice životne dobi od 25 do 29,9 godina i bilo ih je 7 . U trećoj dobnoj grupi je bilo 14 trudnica životne dobi od 30 do 34,9 godina a u četvrtoj dobnoj grupi 5 trudnica starosti preko 35 godina (Slika 34).

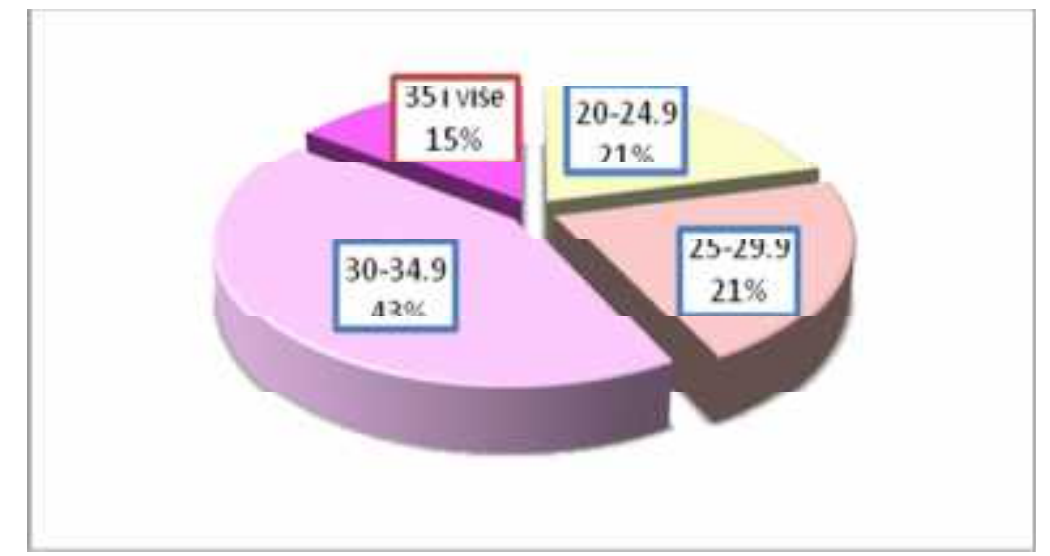

Slika 34. Distribucija trudnica sa PIH prema dobnim grupama 


\subsubsection{Uticaj životne dobi na nivo kreatinina u serumu trudnica sa PIH}

Najviša koncentracija kreatinina u serumu je iznosila $96 \mu \mathrm{mol} / 1$ i dobijena je za trudnice iz dobne grupe 30-34,9 godina, a najniža vrednost serumskog kreatinina, 46 $\mu \mathrm{mol} / 1$, imale su trudnice koje pripadaju dobnim grupama 20-24,9 i 25-29,9 godina (Tabela 45).

Tabela 45. Distribucija kreatinina prema dobnim grupama u serumu trudnica sa PIH

\begin{tabular}{|c|c|c|c|c|c|c|c|}
\hline \multirow{3}{*}{$\begin{array}{l}\text { Dobne } \\
\text { grupe }\end{array}$} & \multicolumn{7}{|c|}{ Kreatinin $(\mu \mathrm{mol} / \mathrm{l})$} \\
\hline & \multirow[b]{2}{*}{$\mathbf{N}$} & \multirow{2}{*}{$\overline{\mathbf{x}}$} & \multirow[b]{2}{*}{ SD } & \multicolumn{2}{|c|}{$\begin{array}{l}95 \% \text { Granica } \\
\text { pouzdanosti }\end{array}$} & \multirow[b]{2}{*}{ Min } & \multirow[b]{2}{*}{ Maks } \\
\hline & & & & $\begin{array}{l}\text { Donja } \\
\text { granica }\end{array}$ & $\begin{array}{l}\text { Gornja } \\
\text { granica }\end{array}$ & & \\
\hline $20-24,9$ & 7 & 63,86 & 11,04 & 53,65 & 74,06 & 46 & 78 \\
\hline $25-29,9$ & 7 & 62,43 & 10,42 & 52,79 & 72,07 & 46 & 74 \\
\hline $30-34,9$ & 14 & 67,64 & 11,77 & 60,85 & 74,44 & 53 & 96 \\
\hline 35 i više & 5 & 64,60 & 8,26 & 54,34 & 74,86 & 53 & 76 \\
\hline Ukupno & 33 & 65,27 & 10,62 & 61,51 & 69,04 & 46 & 96 \\
\hline
\end{tabular}

Primenom ANOVA testa zaključili smo da u odnosu na dobnu grupu kojoj pripadaju trudnice sa PIH nemaju statistički značajno različite prosečne vrednosti kreatinina u serumu $(\mathrm{F}=0424 \mathrm{p}>0,05)($ Slika 35).

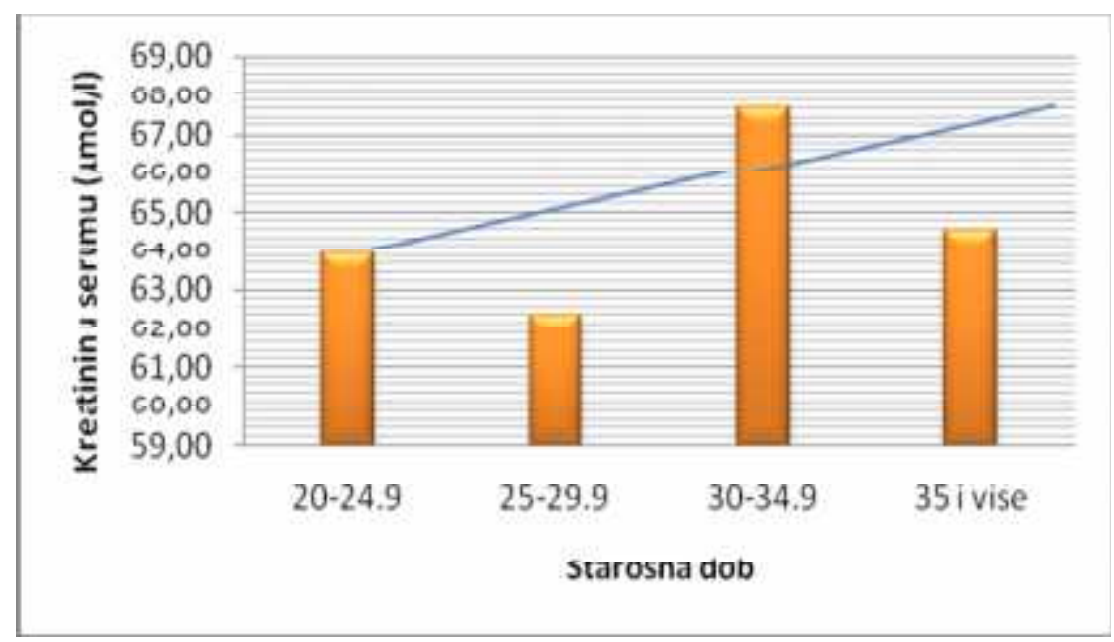

Slika 35. Vrednosti kreatinina zavisno od životne dobi trudnica sa PIH 
Tabela 46. LSD testiranje među dobnim grupama prosečnih vrednosti kreatinina $u$ serumu trudnica sa PIH

\begin{tabular}{|c|c|c|c|c|c|c|}
\hline \multicolumn{7}{|c|}{ Kreatinin $\mu \mathrm{mol} / \mathrm{l}$} \\
\hline \multirow[b]{2}{*}{$\begin{array}{l}\text { Dobne } \\
\text { grupe- }\end{array}$} & \multirow[b]{2}{*}{$\begin{array}{l}\text { Dobne } \\
\text { grupe- }\end{array}$} & \multirow[b]{2}{*}{$\begin{array}{l}\text { Srednja } \\
\text { razlika } \\
\text { grupa }\end{array}$} & \multirow[b]{2}{*}{ SE } & \multirow[b]{2}{*}{ Sig. } & \multicolumn{2}{|c|}{$\begin{array}{l}95 \% \text { granica } \\
\text { pouzdanosti }\end{array}$} \\
\hline & & & & & $\begin{array}{l}\text { Donja } \\
\text { granica }\end{array}$ & $\begin{array}{l}\text { Gornja } \\
\text { granica }\end{array}$ \\
\hline \multirow[t]{3}{*}{$20-24,9$} & $25-29,9$ & 1,428571 & 5,836007 & 0,808346 & $-10,5074$ & 13,36455 \\
\hline & $30-34,9$ & $-3,78571$ & 5,05413 & 0,45987 & $-14,1226$ & 6,551142 \\
\hline & 35 i više & $-0,74286$ & 6,393025 & 0,908297 & $-13,8181$ & 12,33235 \\
\hline \multirow[t]{3}{*}{$25-29,9$} & $20-24,9$ & $-1,42857$ & 5,836007 & 0,808346 & $-13,3645$ & 10,5074 \\
\hline & $30-34,9$ & $-5,21429$ & 5,05413 & 0,310746 & $15,5511-$ & 5,122571 \\
\hline & 35 i više & $-2,17143$ & 6,393025 & 0,736563 & $-15,2466$ & 10,90378 \\
\hline \multirow[t]{3}{*}{$30-34,9$} & $20-24,9$ & 3,785714 & 5,05413 & 0,45987 & $-6,55114$ & 14,12257 \\
\hline & $25-29,9$ & 5,214286 & 5,05413 & 0,310746 & $-5,12257$ & 15,55114 \\
\hline & 35 i više & 3,042857 & 5,688236 & 0,596771 & $-8,59089$ & 14,67661 \\
\hline \multirow[t]{3}{*}{35 i više } & $20-24,9$ & 0,742857 & 6,393025 & 0,908297 & $-12,3323$ & 13,81806 \\
\hline & $25-29,9$ & 2,171429 & 6,393025 & 0,736563 & $-10,9038$ & 15,24663 \\
\hline & $30-34,9$ & $-3,04286$ & 5,688236 & 0,596771 & $-14,6766$ & 8,590891 \\
\hline
\end{tabular}

Dodatnim LSD testiranjem među dobnim grupama potvrdili smo da životna dob trudnica sa PIH ne utiče na prosečnu vrednost kreatinina u serumu (Tabela 46).

\subsubsection{Uticaj životne dobi na nivo klirensa kreatinina trudnica sa PIH}

Najviša vrednost klirensa kreatinina je bila 153,6 i zabeležena je kod trudnice iz dobne grupe 20-24,9 dok je najniži klirens imala trudnica iz dobne grupe 25-29,9 godina. Trudnice sa PIH koje su imale preko 35 godina imale su najniže prosečne vrednosti klirensa kreatinina, dok su kod ostalih starosnih grupa bile približne vrednosti klirensa kreatinina (Tabela 47). 
Tabela 47. Distribucija klirensa kreatinina u serumu trudnica sa PIH prema dobnim grupama

\begin{tabular}{|l|c|c|c|c|c|c|c|}
\hline \multirow{2}{*}{$\begin{array}{l}\text { Dobne } \\
\text { grupe }\end{array}$} & \multicolumn{7}{|c|}{ Klirens kreatinin } \\
\cline { 2 - 7 } & $\mathbf{N}$ & $\overline{\mathbf{x}}$ & $\mathbf{S D}$ & $\begin{array}{c}\text { 95\% Granica } \\
\text { pouzdanosti }\end{array}$ & & \\
\cline { 3 - 8 } & & & $\begin{array}{c}\text { Donja } \\
\text { granica }\end{array}$ & $\begin{array}{c}\text { Gornja } \\
\text { granica }\end{array}$ & Min & Maks. \\
\hline $\mathbf{2 0}-\mathbf{2 4 , 9}$ & 7 & 108,09 & 25,17 & 84,80 & 131,37 & 74,4 & 153,6 \\
\hline $\mathbf{2 5}-\mathbf{2 9 , 9}$ & 7 & 103,20 & 24,97 & 80,10 & 126,30 & 60 & 126 \\
\hline $\mathbf{3 0}-\mathbf{3 4 , 9}$ & 14 & 108,17 & 24,52 & 94,01 & 122,33 & 61,2 & 142,2 \\
\hline $\mathbf{3 5}$ i više & 5 & 81,48 & 16,91 & 60,48 & 102,48 & 66 & 106,8 \\
\hline Ukupno & $\mathbf{3 3}$ & $\mathbf{1 0 3 , 0 5}$ & $\mathbf{2 4 , 6 1}$ & $\mathbf{9 4 , 3 3}$ & $\mathbf{1 1 1 , 7 8}$ & $\mathbf{6 0}$ & $\mathbf{1 5 3 , 6}$ \\
\hline
\end{tabular}

ANOVA testom smo pokazali da $\mathrm{u}$ odnosu na dobnu grupu kojoj pripadaju trudnice sa PIH imaju statistički neznačajno različite prosečne vrednosti kreatinina $u$ serumu $(\mathrm{F}=1,682 \mathrm{p}=0,193)$.

Vrednosti klirensa kreatinina imaju trend opadanja tj. sa starošću opada klirens kreatinina (Slika 36).

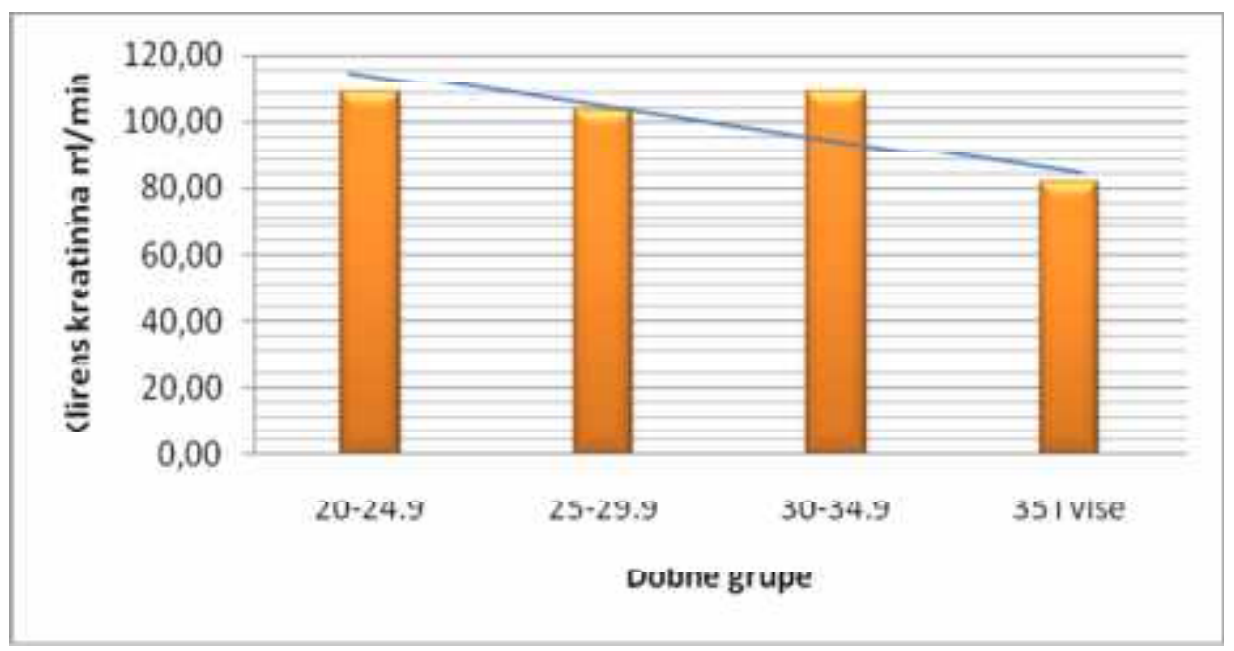

Slika 36. Vrednosti klirensa kreatinina zavisno od životne dobi trudnica sa PIH

Dodatno LSD testiranje je pokazalo da je kod trudnica sa PIH statistički značajna razlika $(\mathrm{p}<0,05)$ vrednosti klirensa kreatinina postojala između starosnih grupa 30-34,9 u odnosu na dob preko 35 godina (Tabela 48). 
Tabela 48. LSD testiranje prosečnih vrednosti klirensa kreatinina u serumu među dobnim grupama trudnica sa PIH

\begin{tabular}{|c|c|c|c|c|c|c|}
\hline \multicolumn{7}{|c|}{ Klirens kreatinina ml/min } \\
\hline \multirow[b]{2}{*}{$\begin{array}{l}\text { Dobne } \\
\text { grupe- }\end{array}$} & \multirow[b]{2}{*}{$\begin{array}{l}\text { Dobne } \\
\text { grupe- }\end{array}$} & \multirow[b]{2}{*}{$\begin{array}{l}\text { Srednja } \\
\text { razlika } \\
\text { među } \\
\text { grupama }\end{array}$} & \multirow[b]{2}{*}{ SE } & \multirow[b]{2}{*}{ Sig. } & \multicolumn{2}{|c|}{$\begin{array}{c}95 \% \text { Granica } \\
\text { pouzdanosti }\end{array}$} \\
\hline & & & & & $\begin{array}{l}\text { Donja } \\
\text { granica }\end{array}$ & $\begin{array}{l}\text { Gornja } \\
\text { granica }\end{array}$ \\
\hline \multirow[t]{3}{*}{$20-24,9$} & $25-29,9$ & 4,885714 & 12,75208 & 0,704417 & $-21,1952$ & 30,96664 \\
\hline & $30-34,9$ & $-0,08571$ & 11,04362 & 0,99386 & $-22,6725$ & 22,50103 \\
\hline & 35 i više & 26,60571 & 13,9692 & 0,066794 & $-1,9645$ & 55,17593 \\
\hline \multirow[t]{3}{*}{$25-29,9$} & $20-24,9$ & $-4,88571$ & 12,75208 & 0,704417 & $-30,9666$ & 21,19521 \\
\hline & $30-34,9$ & $-4,97143$ & 11,04362 & 0,65594 & $-27,5582$ & 17,61531 \\
\hline & 35 i više & 21,72 & 13,9692 & 0,130829 & $-6,85022$ & 50,29022 \\
\hline \multirow[t]{3}{*}{$30-34,9$} & $20-24,9$ & 0,085714 & 11,04362 & 0,99386 & $-22,501$ & 22,67246 \\
\hline & $25-29,9$ & 4,971429 & 11,04362 & 0,65594 & $-17,6153$ & 27,55817 \\
\hline & 35 i više & 26,69143 & 12,42919 & 0,040245 & 1,27089 & 52,11197 \\
\hline \multirow[t]{3}{*}{35 i više } & $20-24,9$ & $-26,6057$ & 13,9692 & 0,066794 & $-55,1759$ & 1,964504 \\
\hline & $25-29,9$ & $-21,72$ & 13,9692 & 0,130829 & $-50,2902$ & 6,850219 \\
\hline & $30-34,9$ & $-26,6914$ & 12,42919 & 0,040245 & $-52,112$ & $-1,27089$ \\
\hline
\end{tabular}

*p $<0,05$ postoji značajna korelacija među parametrima

\subsubsection{Uticaj životne dobi na nivo cistatina $\mathrm{C}$ u serumu trudnica sa PIH}

Kod trudnica sa PIH najniža vrednost cistatina $\mathrm{C}$ je dobijena za trudnicu koja pripada dobnoj grupi 20-24,9 godina i iznosila je $0,86 \mathrm{mg} / \mathrm{l}$ dok je najviša koncentracija cistatina C u serumu iznosila 2,54 mg/l i dobijena je za trudnicu koja je starija od 35 godina. Uočljivo je da sa starošću raste nivo cistatina C (Tabela 49).

Primenom ANOVA testa dokazali smo da postoji statistički značajna razlika u vrednostima cistatina $\mathrm{C}$ u odnosu na dobnu grupu kojoj pripadaju trudnice sa PIH $(\mathrm{F}=10,31 \mathrm{p}<0,003)($ Slika 37). 
Tabela 49. Distribucija koncentracija cistatina $\mathrm{C}$ u serumu trudnica sa PIH zavisno od dobne grupe.

\begin{tabular}{|c|c|c|c|c|c|c|c|}
\hline \multirow{3}{*}{$\begin{array}{l}\text { Dobne } \\
\text { grupe }\end{array}$} & \multicolumn{7}{|c|}{ Cistatin C (mg/l) } \\
\hline & \multirow[b]{2}{*}{$\mathbf{N}$} & \multirow{2}{*}{$\overline{\mathbf{x}}$} & \multirow[b]{2}{*}{ SD } & \multicolumn{2}{|c|}{$\begin{array}{l}\text { 95\% Granica } \\
\text { pouzdanosti }\end{array}$} & \multirow[b]{2}{*}{ Min } & \multirow[b]{2}{*}{ Maks. } \\
\hline & & & & $\begin{array}{l}\text { Donja } \\
\text { granica }\end{array}$ & $\begin{array}{l}\text { Gornja } \\
\text { granica }\end{array}$ & & \\
\hline $20-24,9$ & 7 & 1,08 & 0,21 & 0,89 & 1,27 & 0,86 & 1,44 \\
\hline $25-29,9$ & 7 & 1,40 & 0,31 & 1,11 & 1,69 & 1,15 & 1,89 \\
\hline $30-34,9$ & 14 & 1,56 & 0,37 & 1,34 & 1,77 & 1,02 & 2,08 \\
\hline 35 i više & 5 & 1,76 & 0,65 & 0,94 & 2,57 & 1,01 & 2,54 \\
\hline Ukupno & 33 & 1,45 & 0,43 & 1,30 & 1,61 & 0,86 & 2,54 \\
\hline
\end{tabular}

Dodatnim LSD testiranjem među dobnim grupama prosečnih vrednosti cistatina $\mathrm{C}$ $\mathrm{u}$ serumu trudnica sa PIH utvrdili smo da postoji statistički značajna razlika u vrednostima cistatina $\mathrm{C}$ između grupa trudnica sa PIH koje su pripadale dobnoj grupi od 20-24,9 godina $u$ odnosu na trudnice od $30-34,9(\mathrm{p}<0,05)$ i starije od 35 godina $(\mathrm{p}<0,005)($ Tabela 50).

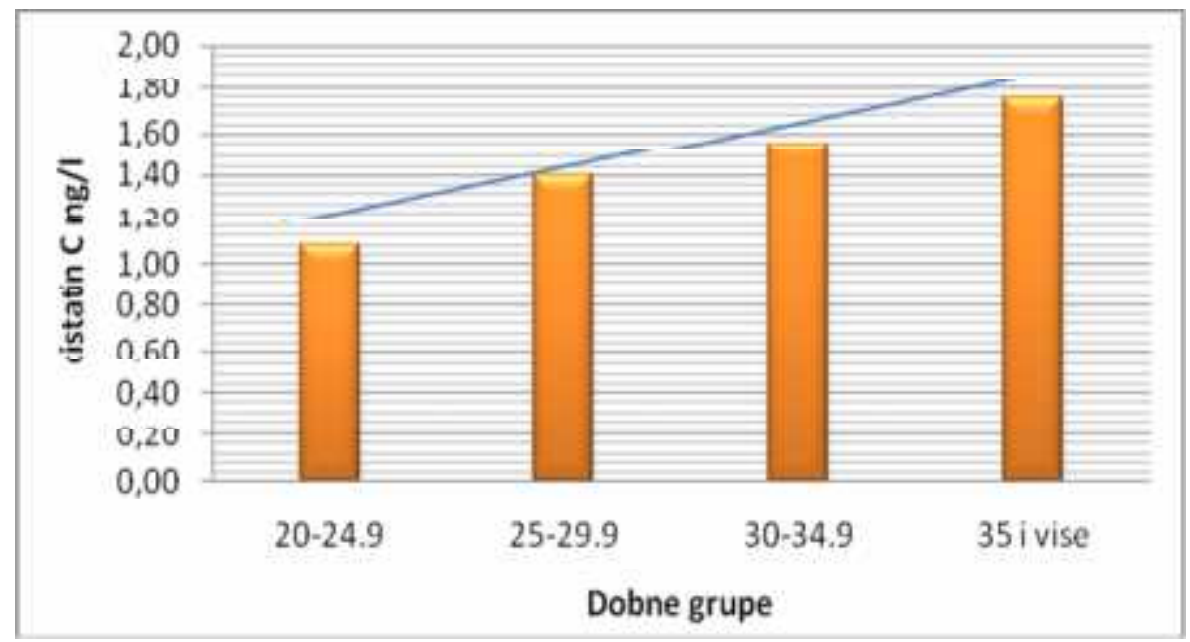

Slika 37. Vrednosti cistatina C zavisno od životne dobi trudnica 
Tabela 50. LSD testiranje među dobnim grupama prosečnih vrednosti cistatina $\mathrm{C} u$ serumu trudnica sa PIH

\begin{tabular}{|c|c|c|c|c|c|c|}
\hline \multicolumn{7}{|c|}{ Cistatin C mg/l } \\
\hline \multirow[b]{2}{*}{$\begin{array}{l}\text { (I) Dobne } \\
\text { grupe- }\end{array}$} & \multirow[b]{2}{*}{$\begin{array}{l}(\mathrm{J}) \\
\text { Dobne } \\
\text { grupe- }\end{array}$} & \multirow[b]{2}{*}{$\begin{array}{l}\text { Srednja razlika } \\
\text { među grupama } \\
\text { (I-J) }\end{array}$} & \multirow[b]{2}{*}{ SE } & \multirow[b]{2}{*}{ Sig. } & \multicolumn{2}{|c|}{$\begin{array}{c}95 \% \text { Interval } \\
\text { pouzdanosti }\end{array}$} \\
\hline & & & & & $\begin{array}{l}\text { Donja } \\
\text { granica }\end{array}$ & $\begin{array}{l}\text { Gornja } \\
\text { granica }\end{array}$ \\
\hline \multirow[t]{3}{*}{$20-24,9$} & $25-29,9$ & $-0,32143$ & 0,20705 & 0,131408 & $-0,74489$ & 0,102036 \\
\hline & $30-34,9$ & $-0,475$ & 0,17931 & 0,012927 & $-0,84173$ & $-0,10827$ \\
\hline & 35 i više & $-0,67314$ & 0,226812 & 0,005958 & $-1,13703$ & $-0,20926$ \\
\hline \multirow[t]{3}{*}{$25-29,9$} & $20-24,9$ & 0,321429 & 0,20705 & 0,131408 & $-0,10204$ & 0,744893 \\
\hline & $30-34,9$ & $-0,15357$ & 0,17931 & 0,398768 & $-0,5203$ & 0,21316 \\
\hline & 35 i više & $-0,35171$ & 0,226812 & 0,131822 & $-0,8156$ & 0,112168 \\
\hline \multirow[t]{3}{*}{$30-34,9$} & $20-24,9$ & 0,475 & 0,17931 & 0,012927 & 0,108269 & 0,841731 \\
\hline & $25-29,9$ & 0,153571 & 0,17931 & 0,398768 & $-0,21316$ & 0,520302 \\
\hline & 35 i više & $-0,19814$ & 0,201807 & 0,334298 & $-0,61089$ & 0,214599 \\
\hline \multirow[t]{3}{*}{35 i više } & $20-24,9$ & 0,673143 & 0,226812 & 0,005958 & 0,209261 & 1,137025 \\
\hline & $25-29,9$ & 0,351714 & 0,226812 & 0,131822 & $-0,11217$ & 0,815596 \\
\hline & $30-34,9$ & 0,198143 & 0,201807 & 0,334298 & $-0,2146$ & 0,610885 \\
\hline
\end{tabular}

${ }^{*} \mathrm{p}<0,05$ postoji značajna korelacija među parametrima

Među ostalim grupama nije bilo statistički značajnih razlika u prosečnim vrednostima cistatina $\mathrm{C}$.

\subsubsection{Uticaj životne dobi na recipročnu vrednost cistatina $C$ trudnica sa PIH}

Recipročna vrednost cistatina $\mathrm{C}$ je opadala sa starošću trudnica sa PIH, najniža je dobijena za trudnicu koja je starija od 35 godina i iznosila je 0,39 dok je najviša dobijena za trudnicu iz najmlađe dobne grupe tj. 20-24,9 godina i iznosila je 1,16 (Tabela 51).

Recipročne vrednosti cistatina $\mathrm{C}$ trudnica sa PIH imale su trend opadanja sa starošću (Slika 38). 
Tabela 51. Distribucija 1/Cistatin C zavisno od dobne grupe trudnica sa PIH

\begin{tabular}{|l|c|c|c|c|c|c|c|}
\hline & \multicolumn{7}{|c|}{ 1/Cistatin C mg/l } \\
\cline { 2 - 6 } \multirow{2}{*}{$\begin{array}{l}\text { Dobne } \\
\text { grupe }\end{array}$} & $\mathbf{N}$ & $\overline{\mathbf{x}}$ & $\mathbf{S D}$ & \multicolumn{2}{|c|}{$\begin{array}{c}\text { 95\% Interval } \\
\text { pouzdanosti }\end{array}$} & \multirow{2}{*}{ Min } & Maks. \\
\cline { 3 - 6 } & & & & $\begin{array}{c}\text { Donja } \\
\text { granica }\end{array}$ & $\begin{array}{c}\text { Gornja } \\
\text { granica }\end{array}$ & & \\
\hline $\mathbf{2 0}-\mathbf{2 4 , 9}$ & 7 & 0,95 & 0,17 & 0,79 & 1,11 & 0,69 & 1,16 \\
\hline $\mathbf{2 5}-\mathbf{2 9 , 9}$ & 7 & 0,74 & 0,14 & 0,61 & 0,87 & 0,53 & 0,87 \\
\hline $\mathbf{3 0}-\mathbf{3 4 , 9}$ & 14 & 0,68 & 0,16 & 0,58 & 0,77 & 0,48 & 0,98 \\
\hline $\mathbf{3 5}$ i više & 5 & 0,64 & 0,26 & 0,32 & 0,96 & 0,39 & 0,99 \\
\hline Ukupno & $\mathbf{3 3}$ & $\mathbf{0 , 7 4}$ & $\mathbf{0 , 2 0}$ & $\mathbf{0 , 6 7}$ & $\mathbf{0 , 8 1}$ & $\mathbf{0 , 3 9}$ & $\mathbf{1 , 1 6}$ \\
\hline
\end{tabular}

Primenom ANOVA testa zaključili smo da među posmatranim dobnim grupama postoji statistički značajna razlika $(\mathrm{F}=4,336 \mathrm{p}<0,05)$.

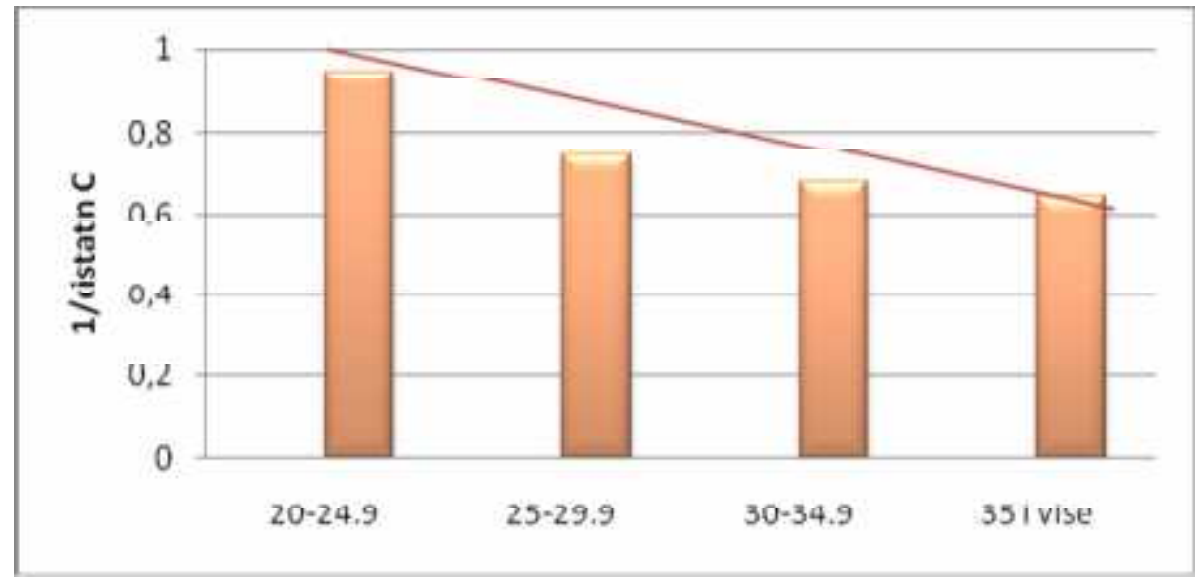

Slika 38. Recipročne vrednosti cistatina $C$ zavisno od životne dobi trudnica

Rezultati dodatnog LSD testiranja prosečnih recipročnih vrednosti cistatina $\mathrm{C} \mathrm{u}$ serumu trudnica sa PIH su pokazali da su trudnice koje su pripadale dobnoj grupi od 20-24,9 godina imale statistički značajno različite vrednosti $(\mathrm{p}<0,05) 1 /$ cistatin $\mathrm{C} \mathrm{u}$ odnosu na sve druge dobne grupe (Tabela 52). 
Tabela 52. LSD testiranje među dobnim grupama prosečnih recipročnih vrednosti cistatina $\mathrm{C}$ u serumu trudnica sa PIH

\begin{tabular}{|c|c|c|c|c|c|c|}
\hline \multicolumn{7}{|c|}{ 1/cistatin C } \\
\hline \multirow[b]{2}{*}{$\begin{array}{l}\text { Dobne } \\
\text { grupe- }\end{array}$} & \multirow[b]{2}{*}{$\begin{array}{l}\text { Dobne } \\
\text { grupe- }\end{array}$} & \multirow[b]{2}{*}{$\begin{array}{c}\text { Srednja } \\
\text { razlika među } \\
\text { grupama }\end{array}$} & \multirow[b]{2}{*}{ SE } & \multirow[b]{2}{*}{ Sig. } & \multicolumn{2}{|c|}{$\begin{array}{l}95 \% \text { Granica } \\
\text { pouzdanosti }\end{array}$} \\
\hline & & & & & $\begin{array}{l}\text { Donja } \\
\text { granica }\end{array}$ & $\begin{array}{l}\text { Gornja } \\
\text { granica }\end{array}$ \\
\hline \multirow{3}{*}{$20-24,9$} & $25-29,9$ & 0,21 & 0,094779 & 0,03472 & 0,016156 & 0,403844 \\
\hline & $30-34,9$ & 0,272143 & 0,082081 & 0,002466 & 0,104269 & 0,440017 \\
\hline & 35 i više & 0,306571 & 0,103825 & 0,006185 & 0,094226 & 0,518917 \\
\hline \multirow[t]{3}{*}{$25-29,9$} & $20-24,9$ & $-0,21$ & 0,094779 & 0,03472 & $-0,40384$ & $-0,01616$ \\
\hline & $30-34,9$ & 0,062143 & 0,082081 & 0,455101 & $-0,10573$ & 0,230017 \\
\hline & 35 i više & 0,096571 & 0,103825 & 0,359978 & $-0,11577$ & 0,308917 \\
\hline \multirow[t]{3}{*}{$30-34,9$} & $20-24,9$ & $-0,27214$ & 0,082081 & 0,002466 & $-0,44002$ & $-0,10427$ \\
\hline & $25-29,9$ & $-0,06214$ & 0,082081 & 0,455101 & $-0,23002$ & 0,105731 \\
\hline & 35 i više & 0,034429 & 0,092379 & 0,71209 & $-0,15451$ & 0,223364 \\
\hline \multirow[t]{3}{*}{35 i više } & $20-24,9$ & $-0,30657$ & 0,103825 & 0,006185 & $-0,51892$ & $-0,09423$ \\
\hline & $25-29,9$ & $-0,09657$ & 0,103825 & 0,359978 & $-0,30892$ & 0,115774 \\
\hline & $30-34,9$ & $-0,03443$ & 0,092379 & 0,71209 & $-0,22336$ & 0,154507 \\
\hline
\end{tabular}

*p $<0,05$ postoji značajna korelacija među parametrima 


\subsection{VREDNOSTI KREATININA, KLIRENSA KREATININA I CISTATINA C KOD BOLESNIKA SA BALKANSKOM ENDEMSKOM NEFROPATIJOM}

Da bi se utvrdilo da li cistatin C može da se primeni za procenu JGF kod obolelih od Balkanske endemske nefropatije (BEN) formirana je grupa od 57 ispitanika koji su bolovali od endemske nefropatije. $U$ ispitivanoj grupi je bilo 26 muškaraca i 31 žena (Slika 39).

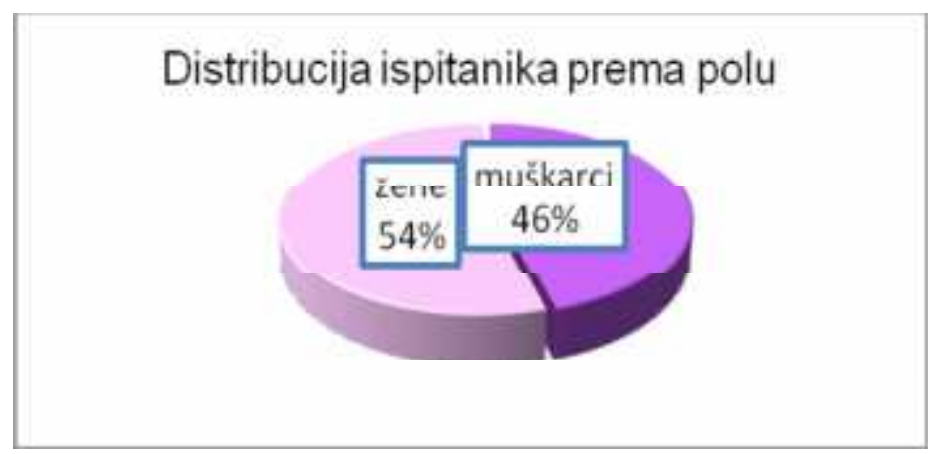

Slika 39. Distribucija ispitanika prema polovima

Prosečna starost ispitivanih osoba bila je 68,9 \pm 9,6 godina. Najmlađi bolesnik je imao 45 godina dok je najstariji imao 83 godine i ujedno je postojala statistički zančajna razlika u godinama bolesnika $(\mathrm{p}<0,05)$.

Bolesnici sa BEN su imali prosečne vrednosti klirensa kreatinina 103,85 \pm 48,05 $\mathrm{ml} / \mathrm{min}$, i vrednost se kretala od $11,7 \mathrm{ml} / \mathrm{min}$, do $203 \mathrm{ml} / \mathrm{min}$.

Srednja vrednost kreatinina bila je 170,42 $\pm 150,79 \mu \mathrm{mol} / \mathrm{l}$ i kretala se od najniže $60 \mu \mathrm{mol} / 1$ do najviše $858 \mu \mathrm{mol} / 1$.

Prosečna vrednost cistatina $C$ je bila $1,94 \pm 1,25 \mathrm{mg} / 1$ dok je najniža vrednost bila $0,76 \mathrm{mg} / 1$ a najviša $6,31 \mathrm{mg} / 1$.

Prosečna recipročna vrednost cistatina $\mathrm{C}$ je kod bolesnika sa $\mathrm{BEN}$ bila $0,70 \pm 0,33$ pri tom je najniža vrednost bila 0,16 a najviša 1,32 .

Ispitivanjem uticaja starosti bolesnika sa BEN na dobijene vrednosti klirensa kreatinina, kreatinina i cistatina $\mathrm{C}$ u serumu utvrdili smo da ne postoji statistički značajna povezanost između starosti ovih bolesnika i klirensa kreatinina $(p=0,8)$. Takođe ne postoji statistički značajna povezanost između starosti bolesnika sa BEN i cistatina $\mathrm{C}(\mathrm{p}>0,05)$ dok je utvrđeno da sa starošću statistički visoko značajno raste nivo kreatinina u serumu bolesnika sa BEN $(p<0,005)$. 
Ispitanici su naknadno podeljeni u četiri grupe zavisno od vrednosti klirensa kreatinina:

I grupa-obuhvata 12 osoba sa vrednostima klirensa kreatinina do 39,9 ml/min

II grupa-obuhvata 13 osoba sa vrednostima klirensa kreatinina od $40 \mathrm{ml} / \mathrm{min}$ do 79,9 $\mathrm{ml} / \mathrm{min}$

III gupa-obuhvata 15 osoba sa vrednostima klirensa kreatinina od od 80 do 119,9 $\mathrm{ml} / \mathrm{min}$

IV grupa-obuhvata 17 osoba sa vrednostima klirensa kreatinina preko $120 \mathrm{ml} / \mathrm{min}$, (Slika 40).

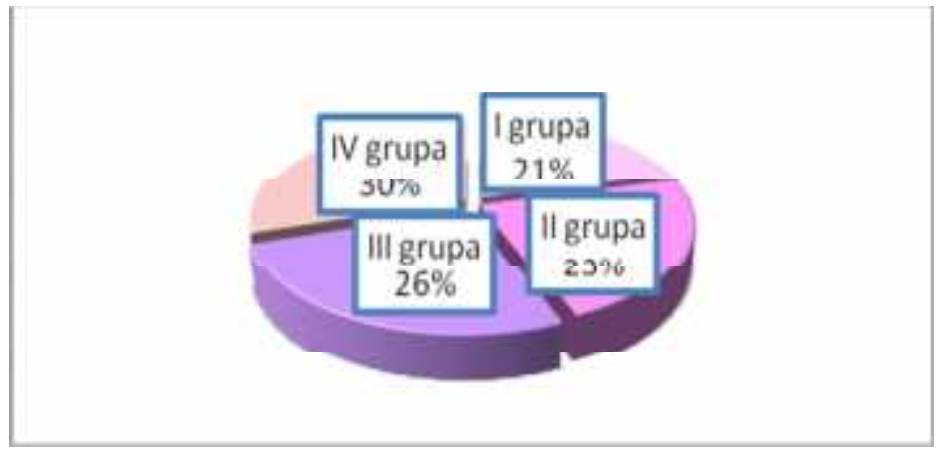

Slika 40. Distribucija ispitanika prema vrednostima klirensa kreatinina

Prosečna starost približno je ista kod osoba koje pripadaju prvoj grupi $(73,2 \pm 8,8$ godina) sa vrednostima klirensa kreatinina manjim od $40 \mathrm{ml} / \mathrm{min}$ i drugoj grupi $(73,12$ godina) sa vrednostima klirensa kreatinina izmedju $40 \mathrm{ml} / \mathrm{min}$ i $80 \mathrm{ml} / \mathrm{min}$, dok je prosečna starost nešto niža u trećoj grupi (61,2 $\pm 9,7$ godina) sa vrednostima klirensa izmedju $80 \mathrm{ml} / \mathrm{min}$ i $120 \mathrm{ml} / \mathrm{min}$ i četvrtoj grupi $(64,1 \pm 9,9$ godine), čiji klirens kreatinina prelazi $120 \mathrm{ml} / \mathrm{min}$.

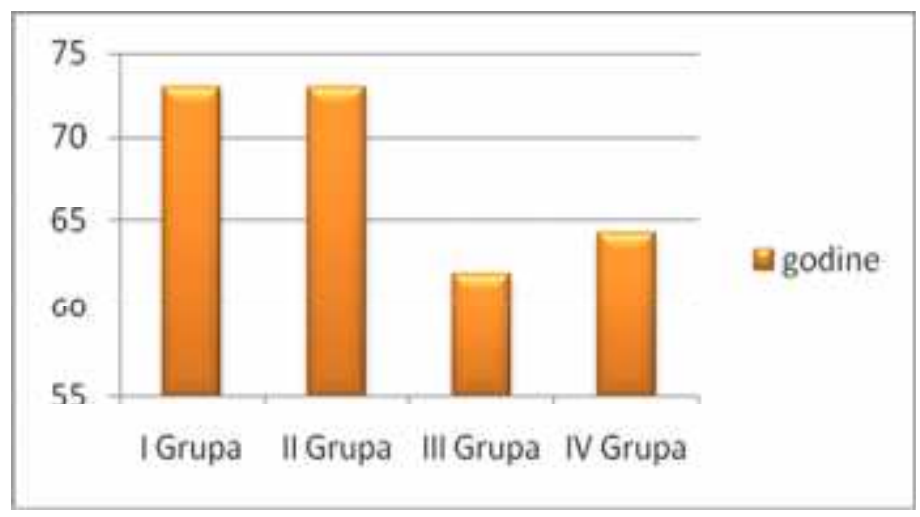

Slika 41. Distribucija starosne dobi ispitanika sa BEN po ispitivanim grupama 
ANOVA testiranje je pokazalo da su bolesnici iz I i II grupe visoko statistički značajno bili stariji u odnosu na bolesnike iz III grupe $(p<0,001)$ i statistički značajno stariji u odnosu na bolesnike iz IV grupe $(\mathrm{p}<0,05)($ Slika 41$)$.

\subsubsection{Vrednosti kreatinina, klirensa kreatinina, cistatina $C$ i recipročne vrednosti cistatina $\mathrm{C}$ kod bolesnika sa BEN zavisno od grupe}

Bolesnici sa BEN čiji je klirens kreatinina bio manji od $40 \mathrm{ml} / \mathrm{min}$, imali su srednje vrednosti kreatinina $345,5 \pm 140,45 \mu \mathrm{mol} / 1$, pri tom je najniža vrednost bila 210 $\mu \mathrm{mol} / 1$ dok je najviša bila $700 \mu \mathrm{mol} / \mathrm{l}$. Bolesnici u drugoj grupi su imali srednju vrednost kreatinina $170,05 \pm 74,96 \mu \mathrm{mol} / 1$, najniži nivo je bio $75 \mu \mathrm{mol} / 1$ dok je najviši nivo bio $350 \mu \mathrm{mol} / 1$. Srednju vrednost kreatinina od $100,3 \pm 47,97 \mu \mathrm{mol} / 1$ imali su ispitanici iz treće grupe sa vrednostima klirensa kreatinina između $80 \mathrm{ml} / \mathrm{min}$ i 119,9 $\mathrm{ml} / \mathrm{min}$, vrednosti su se kretale u rasponu od $60 \mu \mathrm{mol} / 1$ do $235 \mu \mathrm{mol} / 1$ (Tabela 53).

Tabela 53. Distribucija vrednosti kreatinina, klirensa kreatinina, cistatina $C$ i recipročne vrednosti cistatina $\mathrm{C}$ u odnosu na grupe ispitanika sa BEN

\begin{tabular}{|l|c|c|c|c|c|c|c|c|}
\hline & \multicolumn{2}{|c|}{$\begin{array}{c}\text { Klirens } \\
\text { kreatinina } \\
\text { ml/min }\end{array}$} & \multicolumn{2}{|c|}{ Kreatinin $\boldsymbol{\mu m o l / l}$} & \multicolumn{2}{|c|}{ Cistatin C mg/l } & \multicolumn{2}{|c|}{ 1/Cistatin C } \\
\cline { 2 - 9 } & $\begin{array}{c}\text { Srednja } \\
\text { vrednost }\end{array}$ & SD & $\begin{array}{c}\text { Srednja } \\
\text { vrednost }\end{array}$ & SD & $\begin{array}{c}\text { Srednja } \\
\text { vrednost }\end{array}$ & SD & $\begin{array}{c}\text { Srednja } \\
\text { vrednost }\end{array}$ & SD \\
\hline I Grupa & 24,88 & 10,12 & 345,5 & 140,45 & 3,68 & 1,36 & 0,407 & 0,28 \\
II Grupa & 61,6 & 10,5 & 170,5 & 74,96 & 2,23 & 0,68 & 0,49 & 0,15 \\
III Grupa & 110,1 & 28,91 & 100,3 & 47,97 & 1,26 & 0,49 & 0,92 & 0,29 \\
IV Grupa & 136,9 & 8,04 & 83,4 & 31,46 & 1,13 & 0,32 & 0,93 & 0,15 \\
\hline
\end{tabular}

Ispitanici iz četvrte grupe gde su vrednosti klirensa kreatinina više od $120 \mathrm{ml} / \mathrm{min}$ imali su prosečne vrednosti kreatinina $83,4 \pm 31,46 \mu \mathrm{mol} / 1$ a vrednosti su se kretale $\mathrm{u}$ rasponu od $65 \mu \mathrm{mol} / 1$ do $195 \mu \mathrm{mol} / 1$ (Slika 42). 


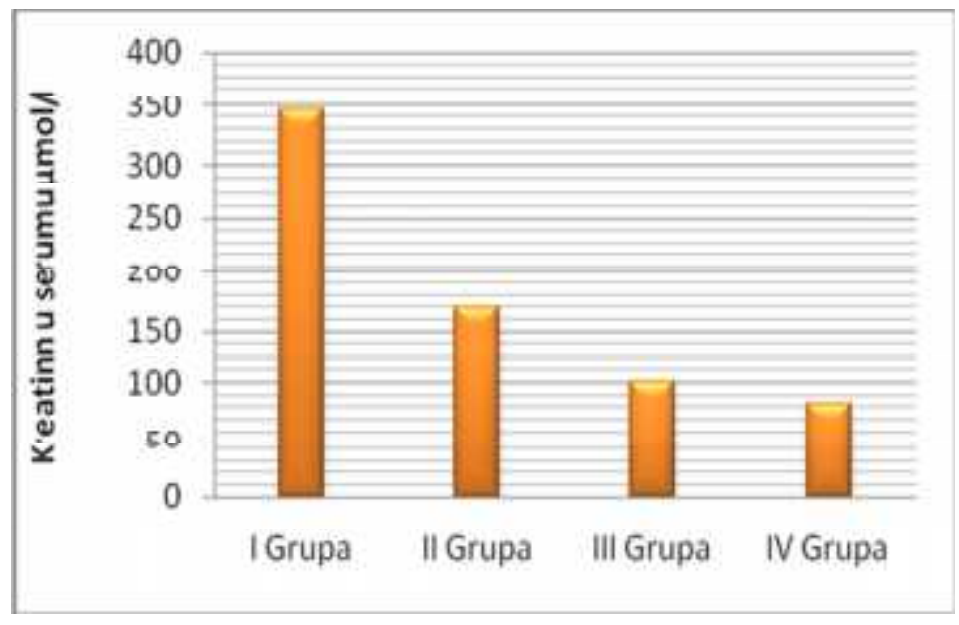

Slika 42. Prosečne vrednosti kreatinina zavisno od grupe ispitanika sa BEN

ANOVA testom je dokazano da su ispitanici iz I grupe imali statistički značajno više $(p<0,01)$ prosečne vrednosti kreatinina $u$ odnosu na sve ostale grupe. Postoji $i$ statistički značajna razlika između II grupe i III grupe kao i između II i IV grupe $(p<0,01)$. Između III i IV grupe nije bilo statistički značajne razlike u vrednostima kreatinina u serumu bolesnika sa BEN ( $p>0,05)$.

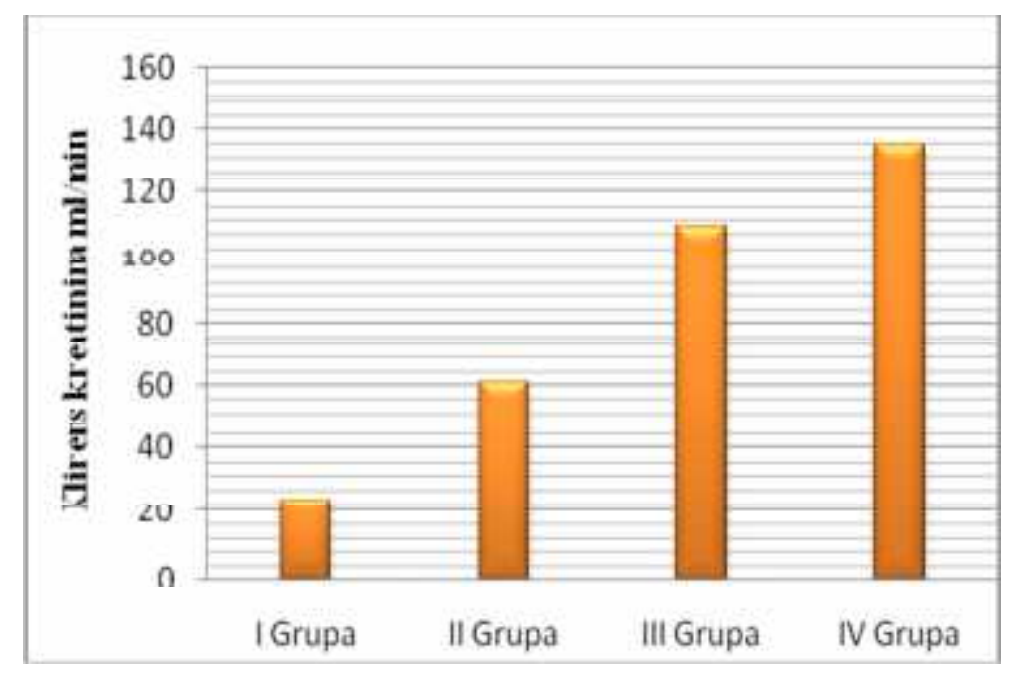

Slika 43. Prosečne vrednosti klirensa kreatinina prema grupama bolesniak sa BEN

Srednja vrednost klirensa kreatinina kod bolesnika u prvoj grupi iznosila je 24,88 $\pm 10,12 \mathrm{ml} / \mathrm{min}$, pri tom je najniža vrednost bila $11,7 \mathrm{ml} / \mathrm{min}$ dok je najviša bila 39,9 $\mathrm{ml} / \mathrm{min}$. U drugoj grupi srednja vrednost klirensa kreatinina je bila $61,6 \pm 10,5 \mathrm{ml} / \mathrm{min}$, 
najniži nivo je bio $46 \mathrm{ml} / \mathrm{min}$ dok je najviši nivo bio $76,4 \mathrm{ml} / \mathrm{min}$, a u trećoj grupi klirens kreatinina je bio $110,1 \pm 28,91 \mathrm{ml} / \mathrm{min}$ i kretao se od $86 \mathrm{ml} / \mathrm{min}$ do $119 \mathrm{ml} / \mathrm{min}$. U četvrtoj grupi srednja vrednost klirensa kreatinina je bila 136,9 $\pm 8,04 \mathrm{ml} / \mathrm{min}$ pri tom je najniža vrednost bila $121 \mathrm{ml} / \mathrm{min}$ dok je najviša bila $185 \mathrm{ml} / \mathrm{min}$ (Slika 43).

Primenom korelacionih testova pokazano je da postoji visoko statistički značajna razlika klirensa kreatinina između I i III, I i IV, II i III, II i IV grupe ( $<<0,01)$. Takođe postoji statistički značajna razlika u klirensu kreatinina između I i II, kao i III i IV grupe ispitanika $(\mathrm{p}<0,05)$.

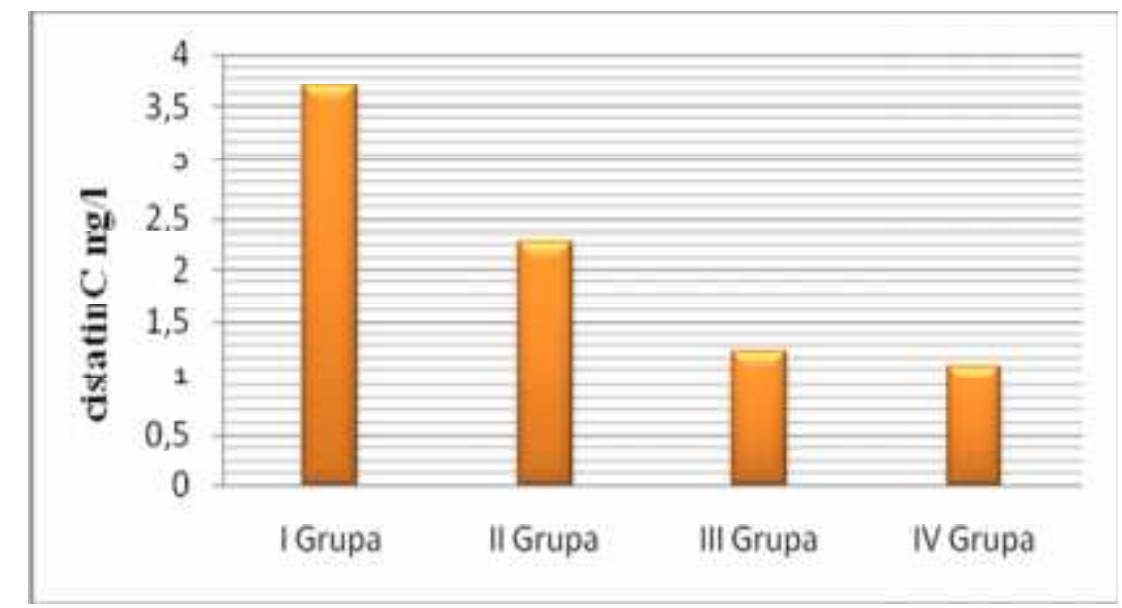

Slika 44. Prosečne vrednosti cistatina $C$ odnosu na grupe ispitanika sa BEN

Prosečna vrednost cistatina $\mathrm{C}$ u prvoj grupi bila je 3,68 mg/l i kretala se u rasponu od 1,0 mg/l do 5,65 mg/l. Srednja vrednosti cistatina C kod bolesnika u drugoj grupi bila je $2,23 \mathrm{mg} / \mathrm{l}$ pri tom je najniža bila $0,94 \mathrm{mg} / \mathrm{l}$ dok je najviša vrednost bila 3,39 mg/l, a u trećoj grupi je bila 1,26 mg/l i kretala se u rasponu od 0,81 mg/l do 2,48 mg/l. Ispitanici u četvrtoj grupi su imali srednju vrednost cistatina $C 1,13 \mathrm{mg} / 1 \mathrm{pri}$ tom je najniža bila $0,78 \mathrm{mg} / \mathrm{l}$ a najviša $1,69 \mathrm{mg} / \mathrm{l}($ Slika 44$)$.

Korelacionim testovima je utvrđeno da postoji statistički značajna razlika $u$ srednjim vrednostima cistatina $C$ između prve $i$ svih ostalih grupa $(p<0,01)$. Između druge $\mathrm{i}$ četvrte grupe postoji statistički značajna razlika $(\mathrm{p}<0,05)$, dok nema statistički značajne razlike srednjih vrednost cistatina $C$ između druge i treće, kao i treće i četvrte grupe ispitanika $(\mathrm{p}>0,05)$.

Srednja recipročna vrednost cistatina $\mathrm{C}$ kod bolesnika u prvoj grupi iznosila je 0,407 i kretala se od 0,17 do 1,00 dok je u drugoj grupi bila 0,49 pri tom je najniža bila 
0,29 a najviša 1,06 . U tećoj grupi srednja recipročna vrednost cistatina $\mathrm{C}$ je bila $0,92 \mathrm{i}$ bila je u rasponu vrednosti od 0,43 do 1,31 a u četvrtoj grupi srednja recipročna vrednost cistatina $\mathrm{C}$ je iznosila 0,93 i kretala se od 0,59 do 1,28 (Slika 45).

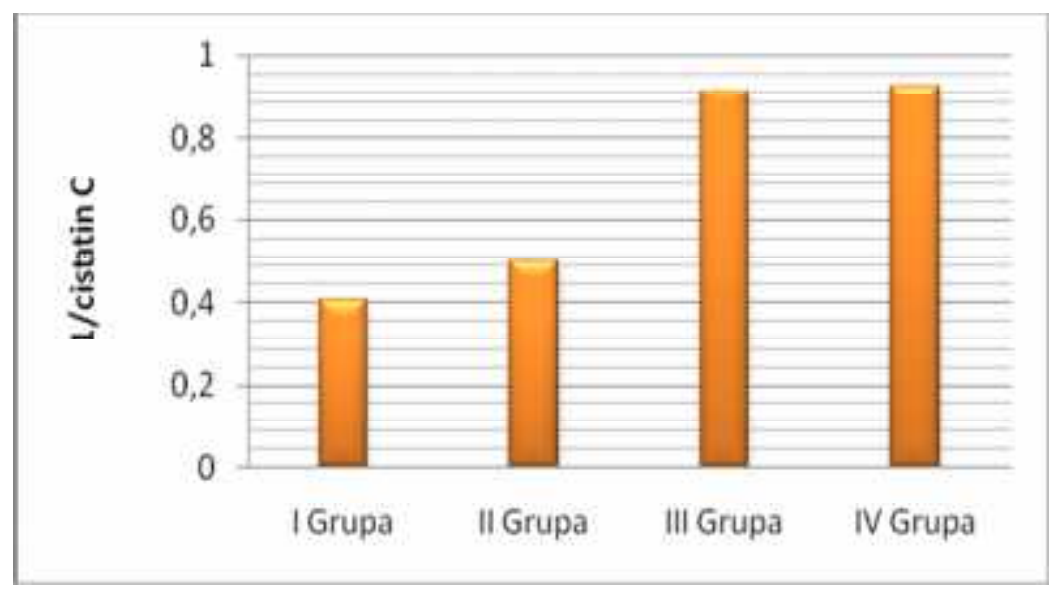

Slika 45. Prosečne recipročne vrednosti cistatina $\mathrm{C}$ u odnosu na grupe ispitanika sa BEN

Primenom ANOVA testa zaključili smo da su statistički značajno različite recipročne vrednosti cistatina $\mathrm{C}$ imali pripadnici I grupe u odnosu na III i IV grupu $(p<0,01)$. Recipročne vrednosti cistatina $\mathrm{C}$ statistički značajno su bile različite kod pripadnika II grupe u odnosu na III i IV grupu $(\mathrm{p}<0,05)$. Nije bilo statistički značajne razlike recipročnih vrednosti cistatina $\mathrm{C}$ između pripadnika I i II grupe, ni između III i IV grupe. 


\subsection{UTICAJ PROTEINURIJE NA KONCENTRACIJU CISTATINA C U SERUMU BOLESNIKA SA NEFROTSKIM SINDROMOM}

U skladu sa jednim od ciljeva ovog rada ispitana je vrednost cistatina $C$, recipročne vrednosti cistatina $\mathrm{C}$, kreatinina i klirensa kreatinina kod 30 bolesnika sa nefrotskim sindromom čija je proteinurija bila preko 3,5 g/24 sata. Radi poređenja ispitana je i grupa zdravih osoba bez proteinurije.

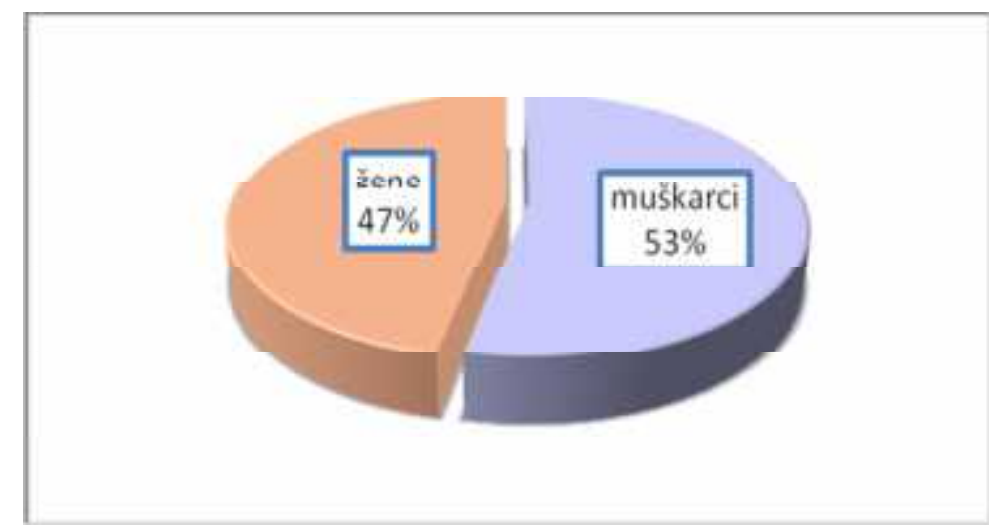

Slika 46 .Distribucija bolesnika sa nefrotskim sindromom prema polu

Grupu je činilo 16 muškaraca i 14 žena prosečne strosti 47,86 $\pm 14,23$ godina (Slika 46). Najmlađi bolesnik bila je žena i imala je 24 godine dok je najstariji bolesnik bio muškarac i imao je 73 godine.

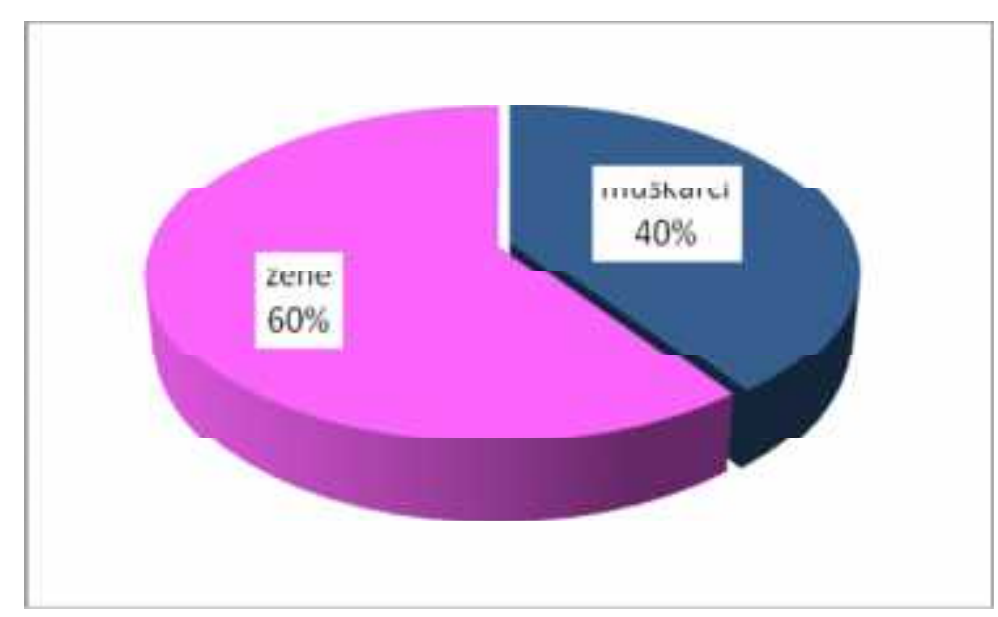

Slika 47. Distribucija kontrolne grupe prema polu 
Kontrolnu grupu je činilo 15 zdravih osoba od kojih je bilo 6 muškaraca i 9 žena, prosečne starosti 35,86 $\pm 9,83$ godina (Slika 47). Najmlađi ispitanik je imao 18 godina i bio je iz grupe muškaraca dok je najstariji ispitanik bila žena i imala je 58 godina.

Prosečan nivo kreatinina u serumu bolesnika sa nefrotskim sindromom bio je $114,70 \pm 41,45 \mu \mathrm{mol} / 1$ dok je u kontrolnoj gupi bio 85,34 $\pm 7,45 \mu \mathrm{mol} / 1$. Bolesnici sa nefrotskim sindromom su imali statistički značajno više vrednosti kreatinina u serumu u odnosu na kontrolnu grupu $(\mathrm{p}<0,05)($ Tabela 54$)$.

Tabela 54. Distribucija vrednosti kreatinina, klirensa kreatinina, cistatina $C$ i recipročne vrednosti cistatina $\mathrm{C}$ kontrolne grupe i bolesnika sa nefrotskim sindromom

\begin{tabular}{|c|c|c|c|c|}
\hline \multirow{2}{*}{ Parametar } & \multicolumn{2}{|c|}{$\begin{array}{c}\text { Bolesnici sa nefrotskim } \\
\text { sindromom }\end{array}$} & \multicolumn{2}{c|}{ Kontrolna grupa } \\
\cline { 2 - 5 } & $\overline{\mathbf{x}}$ & $\mathrm{SD}$ & $\overline{\mathbf{x}}$ & $\mathrm{SD}$ \\
\hline Kreatinin u serumu $(\mu \mathrm{mol} / \mathrm{l})$ & 114,70 & 41,45 & 85,34 & 7,45 \\
\hline Klirens kreatinina $(\mathrm{ml} / \mathrm{min})$ & 75,90 & 29,68 & 99,29 & 13,74 \\
\hline Cistatin C $(\mathrm{mg} / \mathrm{l})$ & 1,45 & 0,62 & 0,82 & 0,11 \\
\hline 1/cistatin C & 0,79 & 0,29 & 1,27 & 0,23 \\
\hline
\end{tabular}

Prosečna vrednost klirensa kreatinina je bila 75,90 $\pm 29,68 \mathrm{ml} / \mathrm{min}$ kod bolesnika sa nefrotskim sindromom i ujedno je bila statistički značajno niža $(p<0,05)$, u odnosu na vrednost dobijenu za kontrolnu grupu koja je iznosila 99,29 $\pm 13,74 \mathrm{ml} / \mathrm{min}$.

Bolesnici sa nefrotskim sindromom su imali prosečnu vrednost cistatina $\mathrm{C} \mathrm{u}$ serumu $1,45 \pm 0,62 \mathrm{mg} / \mathrm{l}$, dok je u kontrolnoj grupi bio $0,82 \pm 0,11 \mathrm{mg} / \mathrm{l}$ što je ujedno predstavljalo statistički značajnu razliku među grupama $(\mathrm{p}<0,05)$.

Prosečna recipročna vrednost cistatina $\mathrm{C}$ je kod bolesnika sa nefrotskim sindromom bila $0,79 \pm 0,29$ i bila je statistički značajno niža u odnosu na prosečnu recipročnu vrednost cistatina $\mathrm{C}$ u kontrolnoj grupi koja je bila 1,27 $\pm 0,23(\mathrm{p}<0,05)$.

Prosečna vrednost proteinurije bolesnika sa nefrotskim sindromom je bila 6,39 \pm $2,95 \mathrm{~g} / 24$ sata. 


\subsubsection{Uticaj životne dobi bolesnika sa nefrotskim sindromom na nivo kreatinina, klirensa kreatinina, cistatina $\mathrm{C}$ i recipročnu vrednost cistatina $\mathrm{C}$}

Da bi se ispitao uticaj životne dobi bolesnika sa nefrotskim sindromom na nivo klirensa kreatinina, kreatinina i cistatina $\mathrm{C}$ u serumu, bolesnike smo prema godinama života razvrstali u tri grupe (Slika 48).

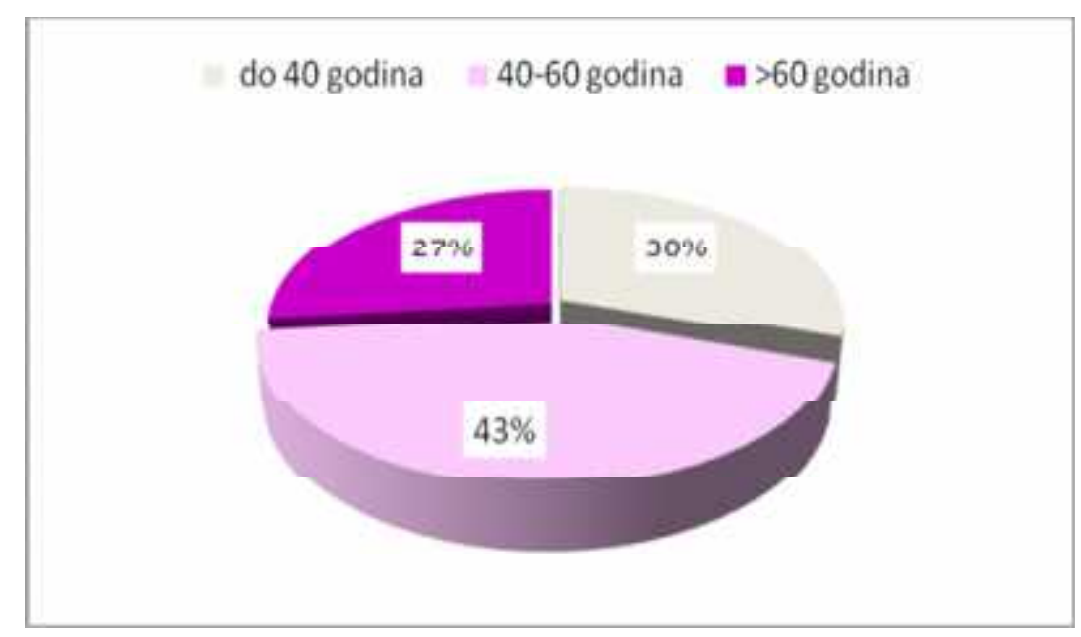

Slika 48. Distribucija bolesnika sa nefrotskim sindromom zavisno od životne dobi

Prvu grupu je činilo 9 bolesnika mlađih od 40 godina, prosečne starosti 30,14 \pm 3,28 godina (Slika 48) i sa prosečnom proteinurijom $6,38 \pm 4,40 \mathrm{~g} / 24$ sata.

U drugoj grupi je bilo najviše bolesnika 13 (43\%), životne dobi od 40 do 60 godina sa prosečnom starošću $48,46 \pm 3,18$ godina i sa prosečnom proteinurijom $6,78 \pm$ $1,98 \mathrm{~g} / 24$ sata.

Treću grupu je činilo 8 bolesnika starijih od 60 godina prosečne starosti $66,86 \pm$ 3,79 godina i sa prosečnom proteinurijom 5,39 $\pm 2,95 \mathrm{~g} / 4$ sata. $\mathrm{U}$ sve tri grupe proteinurija je bila približno istih vrednosti i nije postojala statistički značajna razlika u vrednostima proteinurije u odnosu na grupu $(\mathrm{p}>0,05)$.

Najvišu prosečnu vrednost kreatinina u serumu $127,16 \pm 40,99 \mu \mathrm{mol} / \mathrm{l}$, imali su bolesnici koji su bili u životnoj dobi od 40 - 60 godina, dok su najmlađi i najstariji 
posmatrani bolesnici imali približno jednake prosečne vrednosti kreatinina u serumu (Tabela 55).

Tabela 55. Distribucija vrednosti kreatinina, klirensa kreatinina, cistatina C i recipročne vrednosti cistatina $\mathrm{C}$ bolesnika sa nefrotskim sindromom zavisno od životne dobi

\begin{tabular}{|c|c|c|c|c|c|c|c|c|}
\hline & \multicolumn{2}{|c|}{$\begin{array}{c}\text { Kreatinin } \\
\mu \mathrm{mol} / 1\end{array}$} & \multicolumn{2}{c|}{$\begin{array}{c}\text { Klirens } \\
\text { kreatinina } \\
\mathrm{ml} / \mathrm{min}\end{array}$} & \multicolumn{2}{c|}{$\begin{array}{c}\text { Cistatin C } \\
\mathrm{mg} / 1\end{array}$} & \multicolumn{2}{c|}{ 1/Cistatin C } \\
\hline Godine & $\overline{\mathbf{x}}$ & $\mathrm{SD}$ & $\overline{\mathbf{x}}$ & $\mathrm{SD}$ & $\overline{\mathbf{x}}$ & $\mathrm{SD}$ & $\overline{\mathbf{x}}$ & $\mathrm{SD}$ \\
\hline $\mathbf{d o} \mathbf{4 0}$ & 101,8 & 47,65 & 92,23 & 28,13 & 1,53 & 0,16 & 0,74 & 0,22 \\
$\mathbf{4 0}-\mathbf{6 0}$ & 127,16 & 40,99 & 71,16 & 27,06 & 1,16 & 0,35 & 0,95 & 0,30 \\
$>\mathbf{6 0}$ & 100,6 & 22,17 & 70,21 & 28,66 & 1,34 & 0,20 & 0,76 & 0,09 \\
\hline Ukupno & $\mathbf{1 1 4 , 7}$ & $\mathbf{4 1 , 0 5}$ & $\mathbf{7 5 , 9 0}$ & $\mathbf{2 9 , 6 8}$ & $\mathbf{1 , 4 5}$ & $\mathbf{0 , 6 2}$ & $\mathbf{0 , 7 9}$ & $\mathbf{0 , 2 9}$ \\
\hline
\end{tabular}

Primenom korelacionih testova nije ustanovljena statistički značajna razlika vrednosti kreatinina bolesnika sa nefrotskim sindromom $\mathrm{u}$ odnosu na životnu dob $(\mathrm{p}>0,05)($ Slika 49).

Najvišu prosečnu vrednost klirensa kreatinina 92,23 ml/min, imali su bolesnici koji su pripadali grupi do 40 godina života. Bolesnici srednje i starije životne dobi imali su približno jednake vrednosti klirensa kreatinina (Slika 50).

Primenom korelacionih testova ustanovljena je statistički značajna razlika vrednosti klirensa kreatinina bolesnika sa nefrotskim sindromom u odnosu na životnu dob, tako da bolesnici mlađi od 40 godina imaju statistički značajno više prosečne vrednosti klirensa kreatinina $\mathrm{u}$ odnosu na bolesnike srednje životne dobi $(\mathrm{R}=0,889$ $\mathrm{p}<0,05)$ i u odnosu na bolesnike najstarije životne dobi $(\mathrm{R}=-0,986 \mathrm{p}<0,0001)$. 


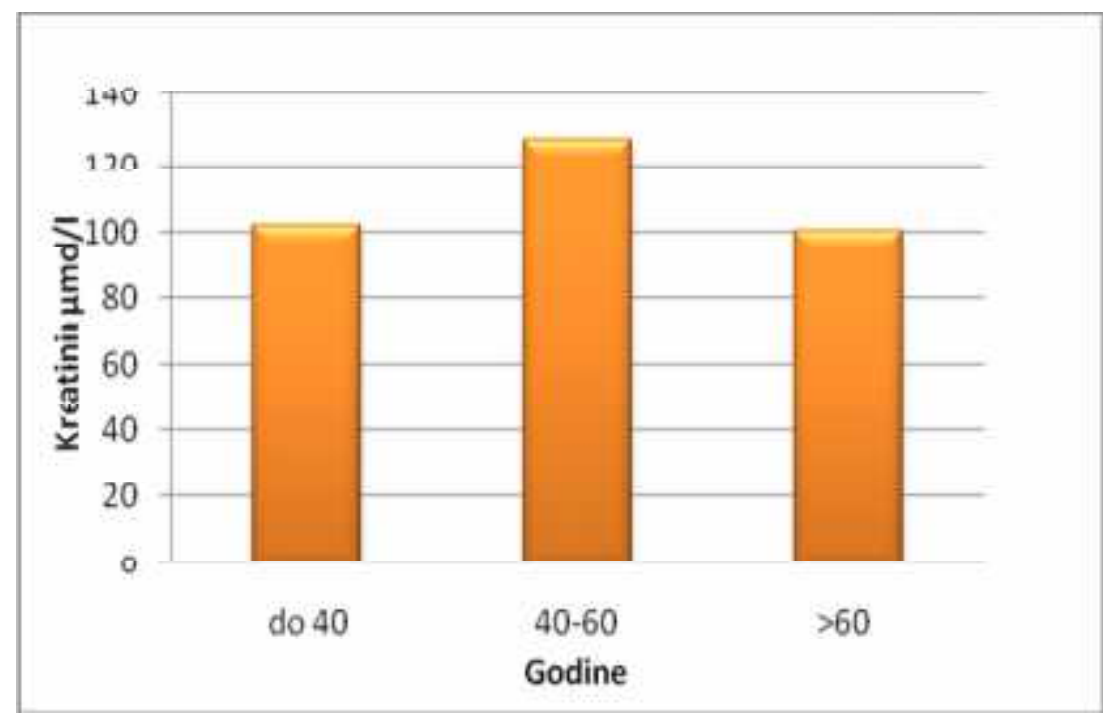

Slika 49. Prosečne vrednosti kreatinina u serumu bolesnika sa nefrotskim sindromom zavisno od životne dobi

Nije bilo statistički značajne razlike između vrednosti klirensa kreatinina bolesnika srednje životne dobi u odnosu na najstarije bolesnike sa nefrotskim sindromom $(\mathrm{p}>0,05)$.

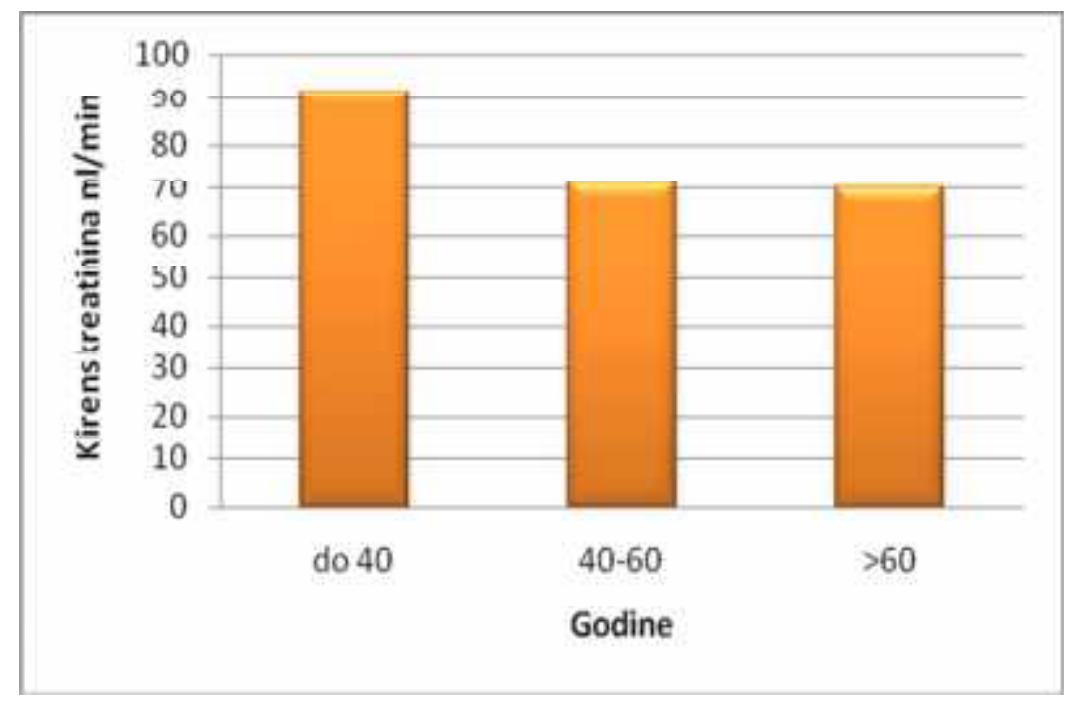

Slika 50. Prosečne vrednosti klirensa kreatinina bolesnika sa nefrotskim sindromom zavisno od životne dobi

Najvišu prosečnu vrednost cistatina $\mathrm{C}$ u serumu $1,53 \mathrm{mg} / \mathrm{l}$, imali su bolesnici mlađi od 40 godina, najnižu prosečnu vrednost cistatina $\mathrm{C} 1,16 \mathrm{mg} / 1$, imali su bolesnici 
od 40 - 60 godina (Tabela 55). Kod starijih od 60 godina prosečna vrednost cistatina $\mathrm{C}$ bila je 1,34 mg/l (Slika 51).

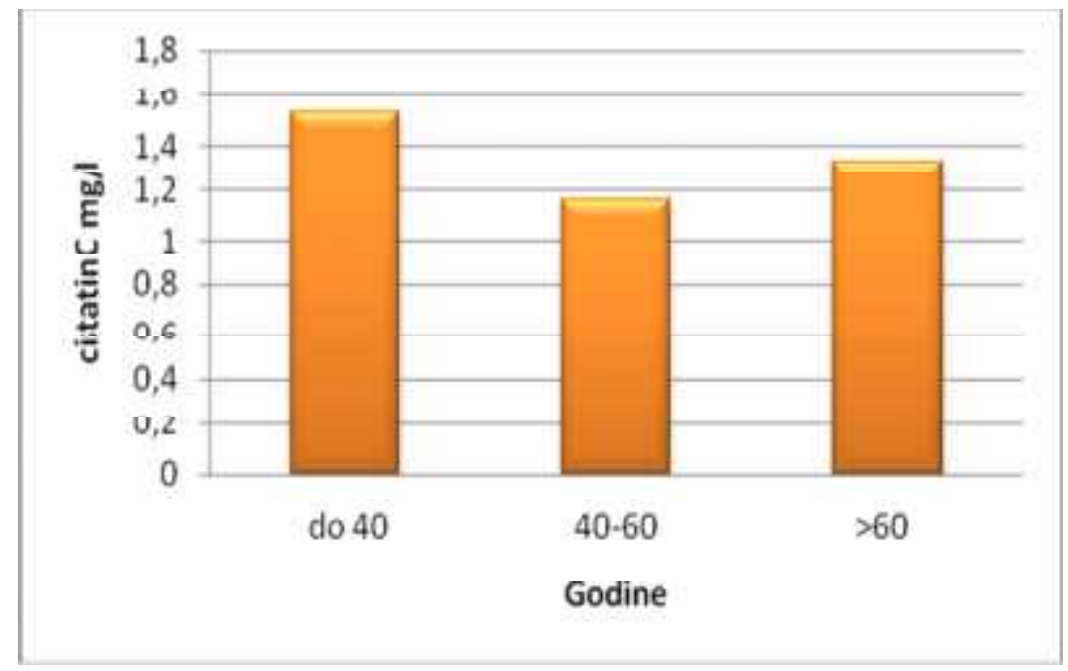

Slika 51. Prosečne vrednosti cistatina $\mathrm{C}$ u serumu bolesnika sa nefrotskim sindromom zavisno od životne dobi

Korelacionim testovima nije ustanovljena statistički značajna razlika vrednosti cistatina $\mathrm{C}$ kod bolesnika sa nefrotskim sindromom u odnosu na životnu dob ( $p>0,05)$.

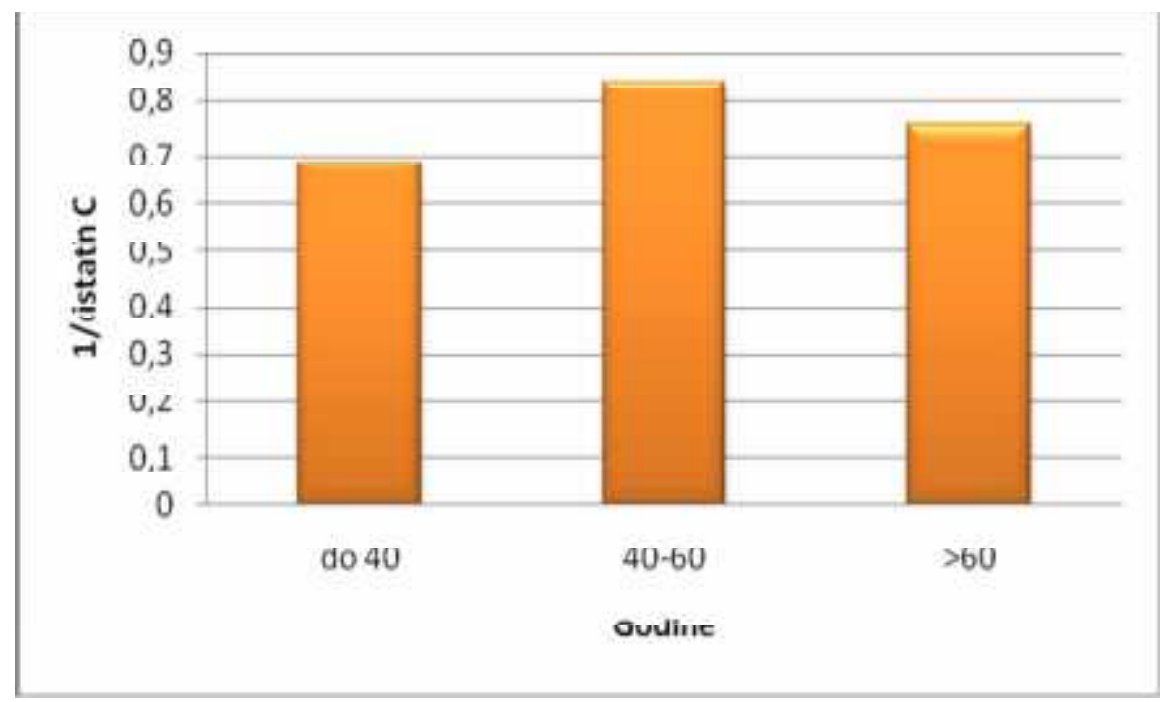

Slika 52. Prosečne recipročne vrednosti cistatina $\mathrm{C}$ u serumu bolesnika sa nefrotskim sindromom zavisno od životne dobi 
Kod bolesnika sa nefrotskim sindromom prosečne recipročne vrednosti cistatina $\mathrm{C}$ su bile najniže u grupi mlađih od 40 godina i iznosile su 0,74 dok su kod najstarijih bolesnika bile 0,79 . U grupi srednje životne dobi prosečna recipročna vrednost cistatina $\mathrm{C}$ je bila 0,95 . Korelacionim testovima nije ustanovljena statistički značajna razlika recipročnih vrednosti cistatina $\mathrm{C}$ bolesnika sa nefrotskim sindromom $\mathrm{u}$ odnosu na životnu dob $(\mathrm{p}>0,05)($ Slika 52). 


\subsection{REZULTATI ODREĐIVANJA KREATININA, KLIRENSA KREATININA I CISTATINA C KOD BOLESNIKA SA DIABETES MELLITUS}

Kao posledica šećerne bolesti često se razvija oštećenje bubrežne funkcije. Da bi utvrdili da li kod Diabetes mellitus (DM) cistatin C može da bude pouzdani pokazatelj JGF cistatin $C$, recipročne vrednosti cistatina $C$, kreatinin i klirens kreatinina su određeni kod 31 bolesnika sa DM tip 2, prosečne starosti 57,29 (najmlađi bolesnik imao je 24 godine, a najstariji 79) godina, od kojih je bilo 15 muškaraca i 16 žena (Slika 53). Svi ispitanici su imali i druge različite bolesti bilo kao posledicu već prisutnog Diabetes mellitus ili nezavisno kao prateću bolest.

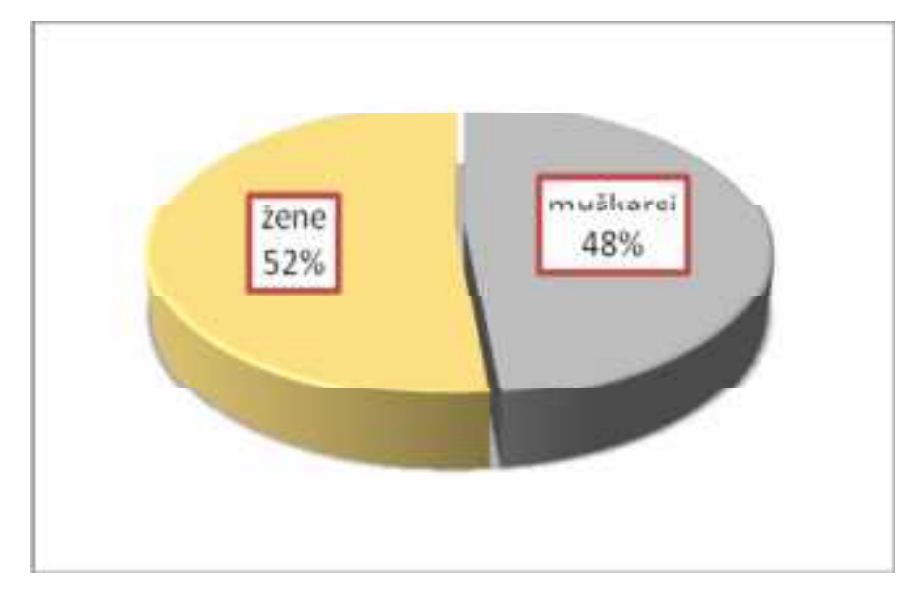

Slika 53. Distribucija bolesnika sa Diabetes mellitus zavisno od pola

U odnosu na klirens kreatinina bolesnici su podeljeni u tri grupe:

I grupa - bolesnici sa vrednostima klirensa kreatinina do $39,9 \mathrm{ml} / \mathrm{min}$

II grupa - bolesnici sa vrednostima klirensa kreatinina od $40 \mathrm{ml} / \mathrm{min}$ do $59,9 \mathrm{ml} / \mathrm{min}$

III gupa - bolesnici sa vrednostima klirensa kreatinina preko $60 \mathrm{ml} / \mathrm{min}$.

Najviše je bilo bolesnika sa prosečnim klirensom ispod $40 \mathrm{ml} / \mathrm{min}$ (Slika 54).

U prvoj grupi bolesnika sa prosečnim klirensom ispod $40 \mathrm{ml} / \mathrm{min}$, bilo je 15 bolesnika, tj. najviše ispitanika (Slika 54). U drugoj grupi sa prosečnim klirensom kreatinina od $40 \mathrm{ml} / \mathrm{min}$ do $59,9 \mathrm{ml} / \mathrm{min}$ bilo je 8 bolesnika, dok je u trećoj grupi bolesnika sa prosečnim klirensom kreatinina preko $60 \mathrm{ml} / \mathrm{min}$ bilo 8 ispitanika. 


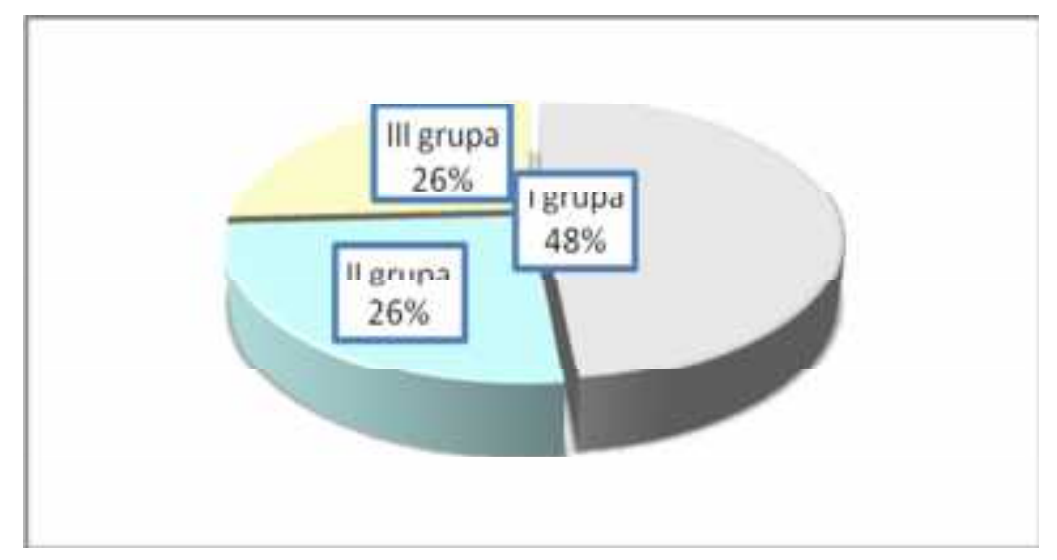

Slika 54. Distribucija bolesnika sa Diabetes mellitus zavisno od klirensa kreatinina

\subsubsection{Uticaj životne dobi na vrednosti klirensa kreatinina, kreatinina, cistatina $C i$ recipročnu vrednost cistatina $\mathrm{C}$ kod bolesnika sa $\mathrm{DM}$}

Grupu sa klirensom kreatinina većim od $60 \mathrm{ml} / \mathrm{min}$ činili su najmlađi bolesnici, prosečne starosti 48 godina dok su u II grupi bili bolesnici prosečne starosti 62,63 godina. U I grupi su bili bolesnici prosečne starosti 60,33 godina (Tabela 56).

Tabela 56. Prosečna starost bolesnika sa DM zavisno od klirensa kreatinina

\begin{tabular}{|c|c|c|c|c|c|c|c|}
\hline \multirow{2}{*}{ Grupe } & \multirow[t]{2}{*}{$\mathbf{N}$} & \multirow{2}{*}{$\begin{array}{c}\text { srednja } \\
\text { vrednost }\end{array}$} & \multirow{2}{*}{ SD } & \multicolumn{2}{|c|}{$\begin{array}{l}\text { 95\% Granica } \\
\text { pouzdanosti }\end{array}$} & \multirow{2}{*}{ Min } & \multirow{2}{*}{ Maks. } \\
\hline & & & & donja & gornja & & \\
\hline $\begin{array}{l}\text { Klirens kreatinina } \\
<40 \mathrm{ml} / \mathrm{min}\end{array}$ & 15 & 60,33 & 16,11 & 51,41 & 69,26 & 30,00 & 79,00 \\
\hline $\begin{array}{l}\text { Klirens kreatinina } \\
\quad<60>40 \mathrm{ml} / \mathrm{min}\end{array}$ & 8 & 62,63 & 6,00 & 57,61 & 67,64 & 59,00 & 77,00 \\
\hline $\begin{array}{c}\text { Klirens kreatinina } \\
>60 \mathrm{ml} / \mathrm{min}\end{array}$ & 8 & 48,00 & 17,58 & 33,30 & 62,70 & 24,00 & 69,00 \\
\hline Ukupno & 31 & 57,74 & 15,39 & 52,10 & 63,39 & 24,00 & 79,00 \\
\hline
\end{tabular}

ANOVA testom nije dokazana statistički značajna razlika u životnoj dobi među grupama $(\mathrm{F}=2,43 \mathrm{p}=0,106)($ Slika 55). 


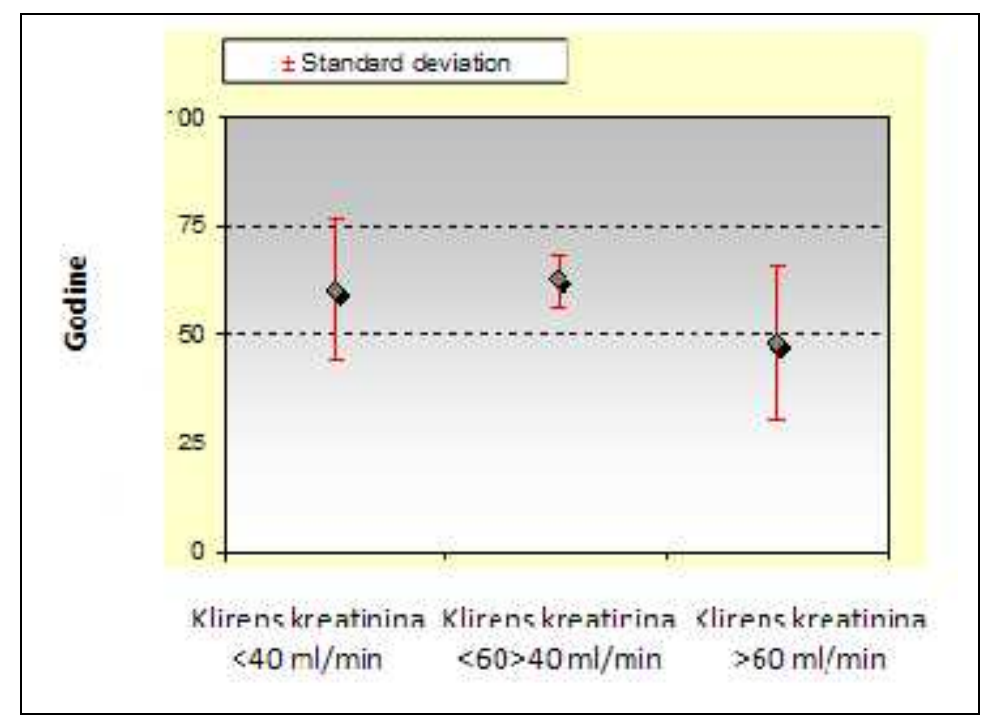

Slika 55. Distribucija životne dobi bolesnika sa DM u odnosu na klirens kreatinina

\subsubsection{Vrednosti kreatinina, klirensa kreatinina, cistatina $C$ i recipročne vrednosti cistatina C kod bolesnika sa DM}

Najvišu prosečnu vrednost kreatinina u serumu 435,27 $\pm 244,00 \mu \mathrm{mol} / 1$, imali su bolesnici koji pripadaju I grupi tj. sa najnižim klirensom kreatinina, dok su bolesnici iz II grupe imali prosečni kreatinin u serumu $168,75 \pm 40,33 \mu \mathrm{mol} / \mathrm{l}$ a u III grupi prosečna vrednost kreatinina je bila 75,25 $\pm 11,88 \mu \mathrm{mol} / 1$ (Tabela 57$)$

Tabela 57. Distirbucija prosečnih vrednosti kreatinina bolesnika sa DM zavisno od grupe

\begin{tabular}{|c|c|c|c|c|c|c|c|c|}
\hline \multirow{2}{*}{\multicolumn{2}{|c|}{ Parametar grupa }} & \multirow{3}{*}{$\begin{array}{r}\mathrm{N} \\
15\end{array}$} & \multirow{3}{*}{$\begin{array}{c}\text { Srednja } \\
\text { vrednost }\end{array}$} & \multirow{3}{*}{$\begin{array}{c}\text { SD } \\
244,00 \\
\end{array}$} & \multicolumn{2}{|c|}{$\begin{array}{l}95 \% \text { Granica } \\
\text { pouzdanosti }\end{array}$} & \multirow{3}{*}{$\begin{array}{c}\text { Min } \\
205,00 \\
\end{array}$} & \multirow{3}{*}{$\begin{array}{l}\text { Maks. } \\
892,00 \\
\end{array}$} \\
\hline & & & & & \multirow{2}{*}{$\begin{array}{c}\begin{array}{c}\text { Donja } \\
\text { granica }\end{array} \\
300,14 \\
\end{array}$} & \multirow{2}{*}{$\begin{array}{l}\begin{array}{l}\text { Gornja } \\
\text { granica }\end{array} \\
570,39 \\
\end{array}$} & & \\
\hline \multirow{4}{*}{$\begin{array}{c}\text { Kreatinin } \\
\mu \mathrm{mol} / 1\end{array}$} & I grupa & & & & & & & \\
\hline & II grupa & 8 & 168,75 & 40,33 & 135,03 & 202,47 & 119,00 & 215,00 \\
\hline & III grupa & 8 & 75,25 & 19,22 & 59,18 & 91,32 & 47,00 & 97,00 \\
\hline & Ukupno & 31 & 273,58 & 233,97 & 187,76 & 359,40 & 47,00 & 892,00 \\
\hline
\end{tabular}

Testiranje (ANOVA) je pokazalo da bolesnici sa DM imaju visoko statistički značajno različite vrednosti kreatinina u serumu u odnosu na grupe koje su formirane 
prema klirensu kreatinina, tako da bolesnici sa nižim klirensom kreatinina statistički značajno imaju više vrednosti kreatinina u serumu $(\mathrm{F}=13,13 \mathrm{p}<0,0001)$ (Slika 56).

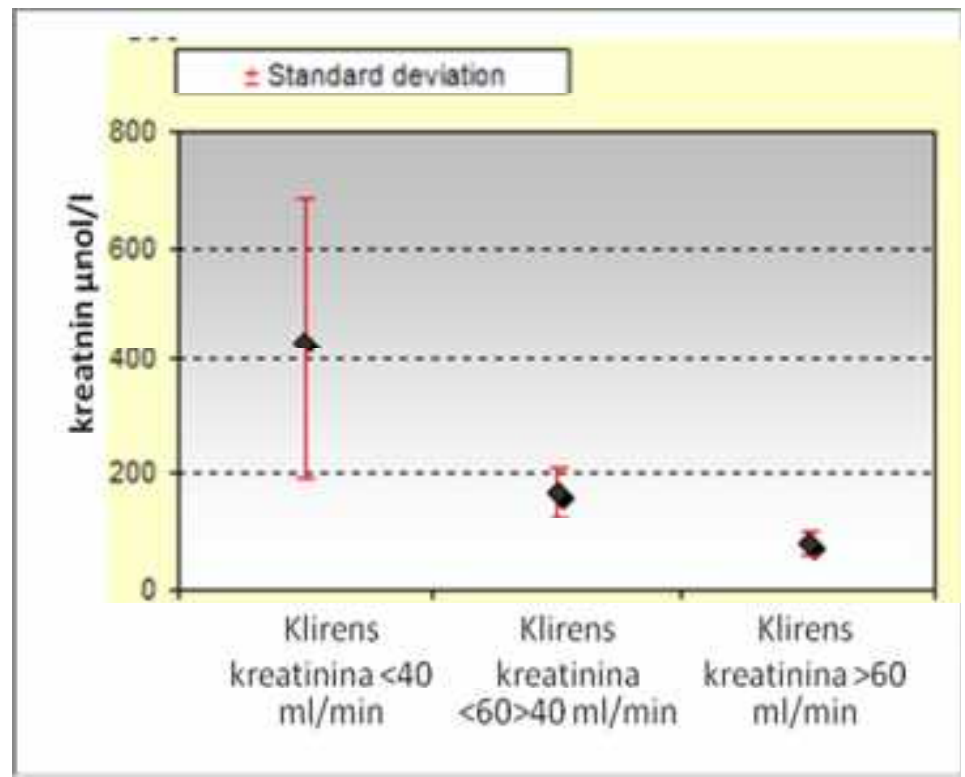

Slika 56. Prosečne vrednosti kreatinina u serumu bolesnika sa DM zavisno od klirensa kreatinina

Najvišu prosečnu vrednost klirensa kreatinina $141,49 \pm 26,79 \mathrm{ml} / \mathrm{min}$ imali su bolesnici koji pripadaju III grupi tj. sa klirensom preko $60 \mathrm{ml} / \mathrm{min}$, dok su bolesnici iz II grupe imali prosečni klirens kreatinina 49,65 $\pm 8,70 \mathrm{ml} / \mathrm{min}$ a u I grupi prosečni klirens kreatinina je bio $17,88 \pm 11,88 \mathrm{ml} / \mathrm{min}$ (Tabela 58 ).

Tabela 58. Distirbucija prosečnih vrednosti klirensa kreatinina bolesnika sa DM zavisno od grupe

\begin{tabular}{|c|c|c|c|c|c|c|c|c|}
\hline \multirow{2}{*}{ Parameta } & \multirow{2}{*}{ grupa } & \multirow{2}{*}{$\mathrm{N}$} & \multirow{2}{*}{$\begin{array}{l}\text { Srednja } \\
\text { vrednost }\end{array}$} & \multirow{2}{*}{ SD } & \multicolumn{2}{|c|}{$\begin{array}{c}95 \% \text { Granica } \\
\text { pouzdanosti }\end{array}$} & \multirow{2}{*}{ Min } & \multirow{2}{*}{ Maks. } \\
\hline & & & & & $\begin{array}{l}\text { Donja } \\
\text { granica }\end{array}$ & $\begin{array}{l}\text { Gornja } \\
\text { granica }\end{array}$ & & \\
\hline \multirow{4}{*}{$\begin{array}{c}\text { Klirens } \\
\text { kreatinina } \\
\mathrm{ml} / \mathrm{min}\end{array}$} & I grupa & 15 & 17,88 & 11,88 & 11,30 & 24,46 & 5,06 & 36,16 \\
\hline & II grupa & 8 & 49,65 & 8,70 & 42,38 & 56,92 & 40,22 & 58,66 \\
\hline & III grupa & 8 & 141,49 & 26,79 & 119,09 & 163,88 & 110,10 & 170,21 \\
\hline & Ukupno & 31 & 57,98 & 54,16 & 38,11 & 77,84 & 5,06 & 170,21 \\
\hline
\end{tabular}


ANOVA testom smo dokazali da se klirens kreatinina bolesnika sa DM statistički značajno razlikuje u odnosu na grupu $(\mathrm{F}=149,64 \mathrm{p}<0,0001)$ (Slika 57).

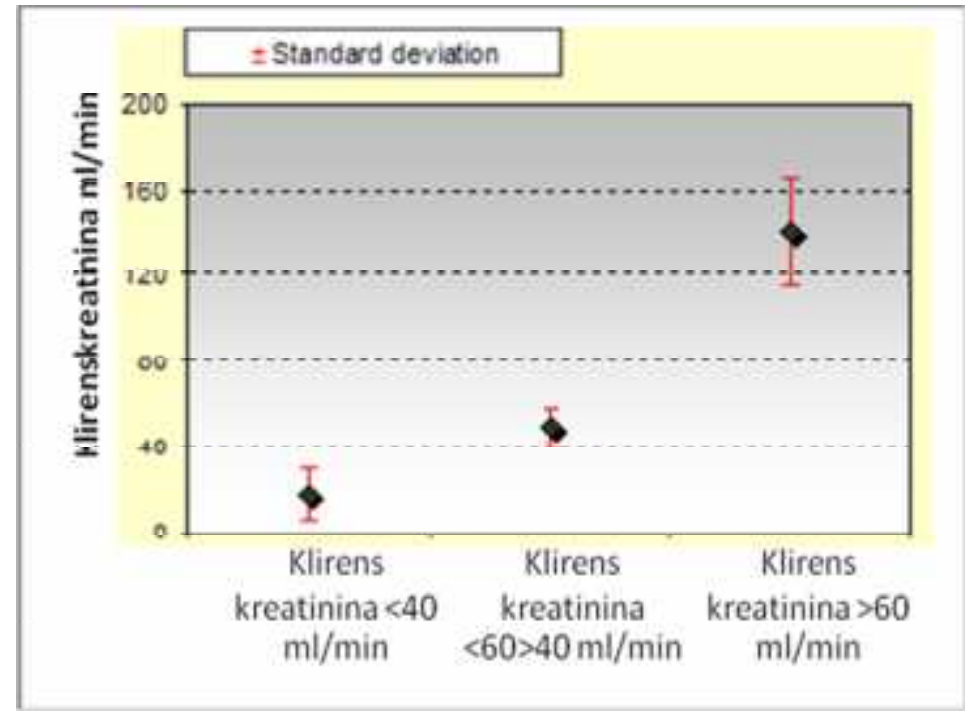

Slika 57. Prosečne vrednosti klirensa kreatinina bolesnika sa DM zavisno od grupe

Bolesnici sa DM čiji je klirens kreatinina bio niži od $40 \mathrm{ml} / \mathrm{min}$ imali su najvišu prosečnu vrednost cistatina $\mathrm{C}$ u serumu $3,18 \pm 1,03 \mathrm{mg} / \mathrm{l}$, dok su bolesnici iz II grupe imali prosečni nivo cistatina $\mathrm{C}$ u serumu 2,22 \pm 0,34 mg/l (Tabela 59).

Tabela 59. Distirbucija prosečnih vrednosti cistatina C bolesnika sa DM zavisno od grupe

\begin{tabular}{|c|c|c|c|c|c|c|c|c|}
\hline \multirow{2}{*}{ Parametar } & \multirow{2}{*}{ grupa } & \multirow{2}{*}{$\mathrm{N}$} & \multirow{2}{*}{$\begin{array}{c}\text { Srednja } \\
\text { vrednost }\end{array}$} & \multirow{2}{*}{ SD } & \multicolumn{2}{|c|}{$\begin{array}{l}\text { 95\% Granica } \\
\text { pouzdanosti }\end{array}$} & \multirow{2}{*}{ Min } & \multirow{2}{*}{ Maks. } \\
\hline & & & & & $\begin{array}{c}\text { Donja } \\
\text { granica }\end{array}$ & $\begin{array}{l}\text { Gornja } \\
\text { granica }\end{array}$ & & \\
\hline \multirow{4}{*}{$\begin{array}{c}\text { Cistatin C } \\
\mathrm{mg} / 1\end{array}$} & I grupa & 15 & 3,18 & 1,03 & 2,61 & 3,75 & 1,76 & 5,02 \\
\hline & II grupa & 8 & 2,22 & 0,34 & 1,93 & 2,50 & 1,75 & 2,60 \\
\hline & III grupa & 8 & 0,93 & 0,23 & 0,74 & 1,11 & 0,67 & 1,24 \\
\hline & Ukupno & 31 & 2,35 & 1,19 & 1,91 & 2,79 & 0,67 & $\mathbf{5 , 0 2}$ \\
\hline
\end{tabular}

Bolesnici sa klirensom kreatinina preko $60 \mathrm{ml} / \mathrm{min}$ imali su najniže vrednosti cistatina $\mathrm{C}, 0,93 \pm 0,23 \mathrm{mg} / \mathrm{l}$. Vrednosti cistatina $\mathrm{C}$ su se visoko statistički značajno 
razlikovale među grupama formiranim prema klirensu kreatinina $(F=23,377 \mathrm{p}<0,0001)$ (Slika 58).

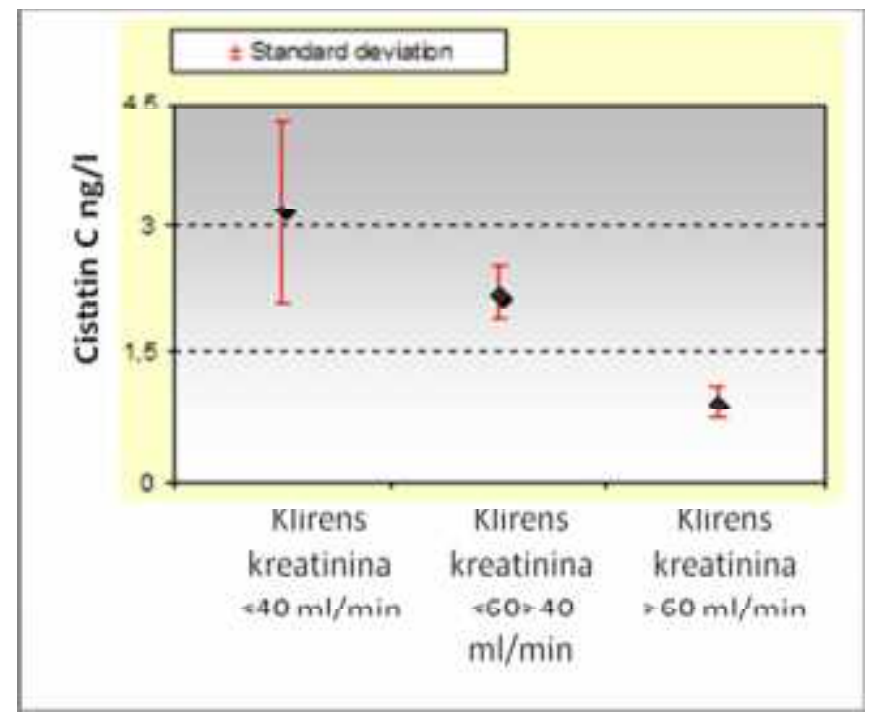

Slika 58. Prosečne vrednosti cistatina $\mathrm{C}$ u serumu bolesnika sa DM zavisno od klirensa kreatinina

Najvišu prosečnu recipročnu vrednost cistatina $C 1,14 \pm 0,27$ imali su bolesnici koji pripadaju III grupi tj. sa najvišim klirensom kreatinina (Tabela 60).

Tabela 60. Distirbucija prosečnih recipročnih vrednosti cistatina $\mathrm{C}$ bolesnika sa DM zavisno od grupe

\begin{tabular}{|c|c|c|c|c|c|c|c|c|}
\hline \multirow{2}{*}{ Parametar } & \multirow{2}{*}{ grupa } & \multirow{2}{*}{$\mathrm{N}$} & \multirow{2}{*}{$\begin{array}{l}\text { Srednja } \\
\text { vrednost }\end{array}$} & \multirow{2}{*}{ SD } & \multicolumn{2}{|c|}{$\begin{array}{l}\text { 95\% Granica } \\
\text { pouzdanosti }\end{array}$} & \multirow{2}{*}{ Min } & \multirow{2}{*}{ Maks. } \\
\hline & & & & & $\begin{array}{l}\text { Donja } \\
\text { granica }\end{array}$ & $\begin{array}{l}\text { Gornja } \\
\text { granica }\end{array}$ & & \\
\hline \multirow{4}{*}{ 1/cistatin C } & I grupa & 15 & 0,34 & 0,12 & 0,28 & 0,41 & 0,20 & 0,57 \\
\hline & II grupa & 8 & 0,46 & 0,07 & 0,40 & 0,52 & 0,39 & 0,57 \\
\hline & III grupa & 8 & 1,14 & 0,27 & 0,91 & 1,37 & 0,81 & 1,49 \\
\hline & Ukupno & 31 & 0,58 & 0,37 & 0,44 & 0,72 & 0,20 & 1,49 \\
\hline
\end{tabular}

Bolesnici iz II grupe su imali prosečnu recipročnu vrednost cistatina C $0,46 \pm 0,07$ a najnižu prosečnu recipročnu vrednost cistatina $C, 0,34 \pm 0,27$ imali su bolesnici sa najnižim klirensom kreatinina tj. iz grupe I. Statistički značajno različite vrednosti 
1/cistatin $\mathrm{C}$ su bile među grupama koje su formirane prema klirensu kreatinina $(\mathrm{F}=65,14$ $\mathrm{p}<0,0001)($ Slika 59).

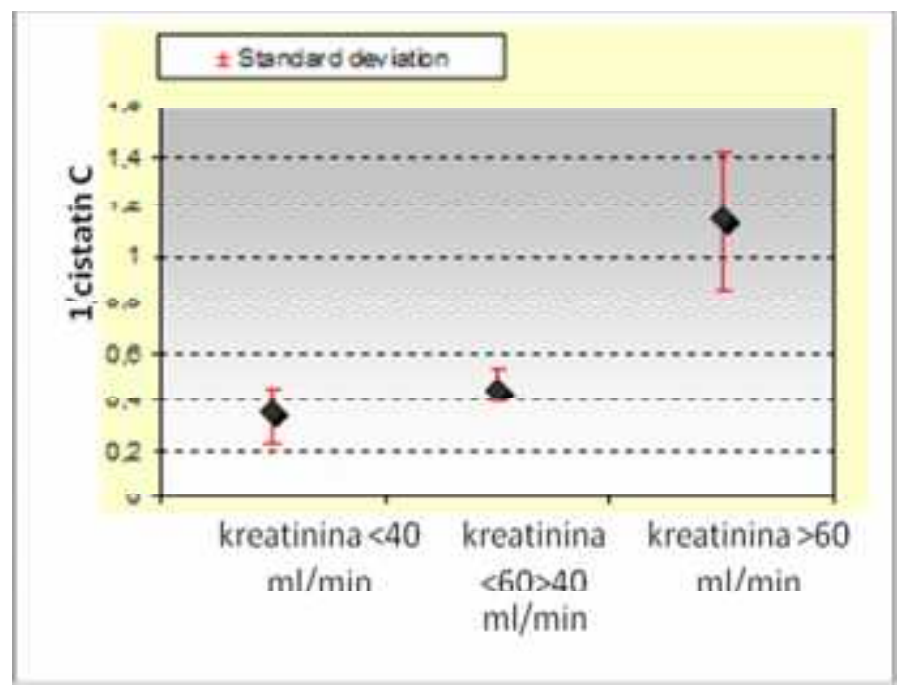

Slika 59. Prosečne recipročne vrednosti cistatina $\mathrm{C}$ u serumu bolesnika sa DM zavisno od klirensa kreatinina

Ispitivana grupa je bila nehomogena što je uslovilo veliki koeficijent varijacije među vrednostima posmatranih parametara pa smo primenili dodatne statističke testove u cilju definisanja razlika među grupama. Primenom Kruskal Wallis testa dokazana je visoko statistički značajna razlika vrednosti klirensa kreatinina, kreatinina, cistatina $\mathrm{C} \mathrm{i}$ recipročne vrednosti cistatina $\mathrm{C}$ među ispitivanim grupama $(\mathrm{p}<0,0001)$.

\subsubsection{Korelacija klirensa kreatinina, koncentracija kreatinina i cistatina $C$ i recipročnih vrednosti cistatina $C$ kod bolesnika sa DM}

Primenom Spearmanovog korelacionog testa utvrdili smo da kod 31 bolesnika sa DM postoji visoko statistički značajna obrnuta korelacija cistatina C sa klirensom kreatinina, tj. višim vrednostima cistatina $\mathrm{C}$ odgovaraju niže vrednosti klirensa kreatinina $(\mathrm{R}=-0,875 \mathrm{p}<0,0001)($ Tabela 61$)$.

Takođe je dokazana direktna visoko statistički značajna korelacija cistatina $\mathrm{C}$ sa kreatininom i obrnuta statistički značajna korelacija cistatina C sa 1/cistatin C. 
Tabela 61. Korelacija klirensa kreatinina, kreatinina i cistatina $\mathrm{C}$ u serumu i recipročnih vrednosti cistatina $\mathrm{C}$ kod bolesnika sa DM

\begin{tabular}{|c|c|c|c|c|c|c|}
\hline \multicolumn{2}{|c|}{ Spearman's } & $\begin{array}{c}\text { Klirens } \\
\text { kreatinina } \\
(\mathrm{ml} / \mathrm{min}) \\
\end{array}$ & $\begin{array}{c}\text { Cistatin } \\
\mathbf{C} \\
(\mathrm{mg} / 1) \\
\end{array}$ & $\begin{array}{l}\text { Kreatinin } \\
\text { u serumu } \\
(\mu \mathrm{mol} / \mathrm{l})\end{array}$ & $\begin{array}{c}\text { 1/cistatin } \\
\text { C }\end{array}$ & Grupa \\
\hline \multirow{3}{*}{$\begin{array}{c}\text { Klirens } \\
\text { kreatinina } \\
(\mathrm{ml} / \mathrm{min})\end{array}$} & $\mathrm{R}$ & 1,000 & $-0,875$ & $-0,975$ & 0,900 & 0,925 \\
\hline & sig & - & 0,000 & 0,000 & 0,000 & 0,000 \\
\hline & $\mathrm{N}$ & 31 & 31 & 31 & 31 & 31 \\
\hline \multirow{3}{*}{$\begin{array}{c}\text { Cistatin C } \\
(\mathrm{mg} / \mathrm{l})\end{array}$} & $\mathrm{R}$ & $-0,875$ & 1,000 & 0,928 & $-0,985$ & $-0,824$ \\
\hline & sig & 0,000 & - & 0,000 & 0,000 & 0,000 \\
\hline & $\mathrm{N}$ & 31 & 31 & 31 & 31 & 31 \\
\hline \multirow{3}{*}{$\begin{array}{c}\text { Kreatinin } \\
\text { u serumu } \\
(\mu \mathrm{mol} / 1)\end{array}$} & $\mathrm{R}$ & $-0,975$ & 0,928 & 1,000 & $-0,949$ & $-0,895$ \\
\hline & sig & 0,000 & 0,000 & - & 0,000 & 0,000 \\
\hline & $\mathrm{N}$ & 31 & 31 & 31 & 31 & 31 \\
\hline \multirow{3}{*}{ 1/cistatin $C$} & $\mathrm{R}$ & 0,900 & $-0,985$ & $-0,949$ & 1,000 & 0,839 \\
\hline & sig & 0,000 & 0,000 & 0,000 & - & 0,000 \\
\hline & $\mathrm{N}$ & 31 & 31 & 31 & 31 & 31 \\
\hline \multirow{3}{*}{ Grupa } & $\mathrm{R}$ & 0,925 & $-0,824$ & $-0,895$ & 0,839 & 1,000 \\
\hline & sig & 0,000 & 0,000 & 0,000 & 0,000 & - \\
\hline & $\mathrm{N}$ & 31 & 31 & 31 & 31 & 31 \\
\hline
\end{tabular}

\subsubsection{Korelacija cistatina $C$ u serumu sa klirensom kreatinina, koncentracijom kreatinina i recipročnim vrednostima cistatina $C$ kod bolesnika sa DM zavisno od grupe}

Ispitivanje međusobnih odnosa posmatranih parametara unutar svake grupe pojedinačno pokazalo je da u I grupi tj. sa klirensom kreatinina $<40 \mathrm{ml} / \mathrm{min}$ postoji statistički značajna obrnuta korelacija cistatina $C$ sa klirensom kreatinina, $(R=-0,697$ $\mathrm{p}<0,005)$.

Takođe postoji i direktna statistički značajna korelacija cistatina $\mathrm{C}$ sa kreatininom, i obrnuta statistički značajna korelacija 1 /cistatina $\mathrm{C}$ sa kreatininom. Klirens kreatinina je u obrnutoj statistički značajnoj korelaciji sa kreatininom u serumu $(\mathrm{p}<0,001)($ Tabela 62) 
Tabela 62. Korelacija klirensa kreatinina, kreatinina i cistatina $\mathrm{C}$ u serumu i recipročnih vrednosti cistatina $\mathrm{C}$ kod bolesnika I grupe sa DM

\begin{tabular}{|c|c|c|c|c|c|}
\hline & & $\begin{array}{c}\text { Klirens } \\
\text { kreatinina } \\
(\mathrm{ml} / \mathrm{min})\end{array}$ & $\begin{array}{c}\text { Cistatin C } \\
(\mathrm{mg} / \mathrm{l})\end{array}$ & $\begin{array}{c}\text { Kreatinin } \\
\text { u serumu } \\
(\mu \mathrm{mol} / \mathrm{l})\end{array}$ & 1/cistatin $\mathrm{C}$ \\
\hline \multirow{3}{*}{\begin{tabular}{|c|} 
Klirens \\
kreatinina \\
$(\mathrm{ml} / \mathrm{min})$ \\
\end{tabular}} & $\mathrm{R}$ & 1,000 & $-0,697$ & $-0,785$ & 0,767 \\
\hline & sig & - & 0,004 & 0,001 & 0,001 \\
\hline & $\mathrm{N}$ & 15 & 15 & 15 & 15 \\
\hline \multirow{3}{*}{$\begin{array}{c}\text { Cistatin C } \\
(\mathrm{mg} / \mathrm{l})\end{array}$} & $\mathrm{R}$ & $-0,697$ & 1,000 & 0,842 & $-0,912$ \\
\hline & sig & 0,004 & - & 0,000 & 0,000 \\
\hline & $\mathrm{N}$ & 15 & 15 & 15 & 15 \\
\hline \multirow{3}{*}{$\begin{array}{c}\text { Kreatinin } \\
\text { u serumu } \\
(\mu \mathrm{mol} / \mathrm{l})\end{array}$} & $\mathrm{R}$ & $-0,785$ & 0,842 & 1,000 & $-0,781$ \\
\hline & sig & 0,001 & 0,000 & - & 0,001 \\
\hline & $\mathrm{N}$ & 15 & 15 & 15 & 15 \\
\hline \multirow{3}{*}{ 1/cistatin C } & $\mathrm{R}$ & 0,767 & $-0,912$ & $-0,781$ & 1,000 \\
\hline & sig & 0,001 & 0,000 & 0,001 & - \\
\hline & $\mathrm{N}$ & 15 & 15 & 15 & 15 \\
\hline
\end{tabular}

U II grupi, koju čine bolesnici sa DM čija je vrednost klirensa kreatinina između $60 \mathrm{ml} / \mathrm{min}$ i $40 \mathrm{ml} / \mathrm{min}$, takođe je utvrđena obrnuta statistički značajna korelacija cistatina $\mathrm{C}$ sa klirensom kreatinina, tj. više vrednosti cistatina $\mathrm{C}$ odgovaraju nižim vrednostima klirensa kreatinina $(\mathrm{R}=-0,707 \mathrm{p}<0,05)($ Tabela 63).

Tabela 63. Korelacija klirensa kreatinina, kreatinina i cistatina $\mathrm{C}$ u serumu i recipročnih vrednosti cistatina C kod bolesnika II grupe sa DM

\begin{tabular}{|c|c|c|c|c|c|}
\hline & & $\begin{array}{c}\text { Klirens } \\
\text { kreatinina } \\
\text { ml/min }\end{array}$ & $\begin{array}{c}\text { Cistatin C } \\
(\mathrm{mg} / \mathrm{l})\end{array}$ & $\begin{array}{c}\text { Kreatinin } \\
\text { u serumu } \\
(\mu \mathrm{mol} / \mathrm{l})\end{array}$ & 1/cistatin $C$ \\
\hline \multirow{3}{*}{$\begin{array}{c}\text { Klirens } \\
\text { kreatinina } \\
\text { ml/min }\end{array}$} & $\mathrm{R}$ & 1,000 & $\begin{array}{l}-0,707 \\
\end{array}$ & $-0,967$ & 0,630 \\
\hline & sig & - & 0,050 & 0,000 & 0,094 \\
\hline & $\mathrm{N}$ & 8 & 8 & 8 & 8 \\
\hline \multirow{3}{*}{$\begin{array}{c}\text { Cistatin C } \\
(\mathrm{mg} / \mathrm{l})\end{array}$} & $\mathrm{R}$ & $-0,707$ & 1,000 & 0,834 & $-0,994$ \\
\hline & sig & 0,050 & - & 0,010 & 0,000 \\
\hline & $\mathrm{N}$ & 8 & 8 & 8 & 8 \\
\hline \multirow{3}{*}{$\begin{array}{c}\text { Kreatinin } \\
\text { u serumu } \\
(\mu \mathrm{mol} / 1) \\
\end{array}$} & $\mathrm{R}$ & $-0,967$ & 0,834 & 1,000 & $-0,779$ \\
\hline & sig & 0,000 & 0,010 & - & 0,023 \\
\hline & $\mathrm{N}$ & 8 & 8 & 8 & 8 \\
\hline \multirow{3}{*}{ 1/cistatin C } & $\mathrm{R}$ & 0,630 & $-0,994$ & $-0,779$ & 1,000 \\
\hline & sig & 0,094 & 0,000 & 0,023 & - \\
\hline & $\mathrm{N}$ & 8 & 8 & 8 & 8 \\
\hline
\end{tabular}

${ }^{*} \mathrm{p}<0,05$ postoji statistička značajnost, ${ }^{*} \mathrm{p}<0,01$ postoji statistička značajnost 
U II grupi je utvrđena direktna statistički značajna korelacija cistatina $\mathrm{C}$ sa kreatininom $(\mathrm{R}=0,8342 \mathrm{p}<0,01)$ i obrnuta statistički značajna korelacija cistatina $\mathrm{C}$ sa $1 /$ cistatin $C(R=-0,994 p<0,0001)$. Takođe kreatinin statistički značajno korelira sa klirensom kreatinina u ovoj grupi $(\mathrm{R}=-0,967 \mathrm{p}<0,01)$.

U III grupi koju su činili bolesnici sa klirensom kreatinina $>60 \mathrm{ml} / \mathrm{min}$ nije dokazana statistički značajna korelacija cistatina $\mathrm{C}$ sa klirensom kreatinina, premda više vrednosti cistatina $\mathrm{C}$ koreliraju sa nižim vrednostima klirensa kreatinina, ali bez statističke značajnosti $(\mathrm{R}=0,310 \mathrm{p}=\mathrm{ns})$ (Tabela 64$)$.

Tabela 64. Korelacija klirensa kreatinina, kreatinina i cistatina $\mathrm{C}$ u serumu i recipročnih vrednosti cistatina $\mathrm{C}$ kod bolesnika III grupe sa DM

\begin{tabular}{|c|c|c|c|c|c|}
\hline & & $\begin{array}{c}\text { Klirens } \\
\text { kreatinina } \\
(\mathrm{ml} / \mathrm{min})\end{array}$ & $\begin{array}{c}\text { Cistatin C } \\
(\mathrm{mg} / \mathrm{l})\end{array}$ & $\begin{array}{c}\text { Kreatinin } \\
\text { u serumu } \\
(\mu \mathrm{mol} / \mathrm{l})\end{array}$ & $\mathbf{1}$ /cistatin C \\
\hline \multirow{2}{*}{$\begin{array}{c}\text { Klirens } \\
\text { kreatinina } \\
(\mathrm{ml} / \mathrm{min})\end{array}$} & $\mathrm{R}$ & 1,000 & 0,310 & $-0,695$ & $-0,134$ \\
\cline { 2 - 6 } & $\mathrm{sig}$ & - & 0,455 & 0,056 & 0,751 \\
\hline \multirow{2}{*}{$\begin{array}{c}\text { istatin C } \\
(\mathrm{mg} / \mathrm{l})\end{array}$} & $\mathrm{R}$ & 0,310 & 1,000 & $-0,578$ & $-0,983$ \\
\cline { 2 - 6 } & $\mathrm{sig}$ & 0,455 & - & 0,133 & 0,000 \\
\cline { 2 - 6 } & $\mathrm{N}$ & 8 & 8 & 8 & 8 \\
\hline \multirow{2}{*}{$\begin{array}{c}\text { Kreatinin } \\
\mathbf{u} \text { serumu } \\
(\mu \mathrm{mol} / \mathrm{l})\end{array}$} & $\mathrm{R}$ & $-0,695$ & $-0,578$ & 1,000 & 0,445 \\
\cline { 2 - 6 } & $\mathrm{sig}$ & 0,056 & 0,133 & - & 0,269 \\
\hline \multirow{2}{*}{$\mathbf{1} /$ cistatin C } & $\mathrm{N}$ & 8 & 8 & 8 & 8 \\
\cline { 2 - 6 } & $\mathrm{R}$ & $-0,134$ & $-0,983$ & 0,445 & 1,000 \\
\cline { 2 - 6 } & $\mathrm{N}$ & 0,751 & 0,000 & 0,269 & - \\
\hline
\end{tabular}

${ }^{*} \mathrm{p}<0,05$ postoji statistička značajnost

Takođe nije dokazana statistički značajna korelacija između cistatina $\mathrm{C}$ i vrednosti kreatinina u serumu iako je sa porastom nivoa kreatinina rastao i nivo cistatina $\mathrm{C}(\mathrm{R}=-$ $0,578 \mathrm{p}=\mathrm{ns}$ ). Očekivano je dokazana statistički značajna korelacija cistatina $\mathrm{C}$ sa $1 /$ cistatin $C$, rast cistatina $C$ korelira sa padom vrednosti $1 /$ cistatin $C(R=-0,983$ $\mathrm{p}<0,0001)($ Tabela 64). 


\section{DISKUSIJA}

Značaj koji bubreg ima u organizmu kao i rasprostranjenost i ozbiljnost bubrežnih bolesti obavezuju profesionalne nacionalne organizacije da izdaju preporuke za praćenje rizičnih grupa da bi se što ranije otkrilo ostecenje bubrega i planirala startegija lečenja i praćenja bolesti bubrega uz edukaciju stanovništva i medicinskih profesionalaca. Izuzetno je značajno da se određenim dijagnostičkim testovima prati stanje i funkcija bubrega jer adekvatan i blagovremen tretman može znatno da uspori progresiju bubrežne slabosti i da u znatnoj meri očuva funkciju bubrega.

Bubreg je izuzetno složen organ sa višestrukom ulogom u održavanju homeostaze u organizmu pa je vrlo teško pronaći idealni pokazatelj koji bi na jednostavan način mogao da proceni funkciju bubrega i obuhvati najveći broj promena koji se dešavaju tokom razvoja patološkog procesa. Bez obzira što se jačinom glomerularne filtracije $u$ prvom redu procenjuju filtracioni procesi u glomerulu, JGF se ipak nameće kao mera preko koje se može pratiti najveći broj promena u funkciji bubrega i progresija oštećenja bubrežne funkcije.

Jačinu glomerulske filtracije nije moguće određivati direktno tako da se određivanje JGF zasniva na merenju koncentracije različitih endogenih i egzogenih supstanci u krvi i u urinu te se na taj način procenjuje JGF. Supstance koje se koriste za merenje JGF moraju da poseduju određena svojstva tj. da ne budu vezana za protein i da se slobodno filtriraju u glomerulima, kao i da se ne reapsorbuju, sekretuju, sintetišu ili metabolišu u tubulima bubrega. Shodno ovome količina supstance koja se filtrira u glomerulima mora da bude ista kao i količina koja se ekskretuje u urin.

Za procenu stanja bubrega najčešće se u kliničkoj praksi koristi kreatinin i njegov renalni klirens. Kreatinin ima molekulsku masu 113 Da, produkt je hidrolize kreatina i fosfokreatina koja se odvija u mišićima, pa je njegova koncentracija u krvi proporcionalna mišićnoj masi. Koncentracija mu se menja kod promene ishrane kao što su mali ili prevelik unos proteina, malnutricija, kao i pri amputaciji ekstremiteta, dužem ležanju u bolnici, kod ciroze jetre, inflamacije i drugih hroničnih bolesti (npr. maligniteti, teške kardiovaskularne bolesti). Kreatininemija zavisi od pola, starosne dobi 
i rase pa je i zato nepouzdana za preciznu procenu JGF i to naročito kod početnih oštećenja bubrežne funkcije (32). Smatra se da neki od nedostataka serumskog kreatinina $\mathrm{u}$ proceni JGF mogu da budu prevaziđeni upotrebom njegovog renalnog klirensa. Uobičajeno je da se u laboratorijama meri klirens kreatinina tako što se urin sakuplja 24 sata i tokom tog perioda se uzima krv za utvrđivanje koncentracije kreatinina $\mathrm{u}$ serumu. Poseban nedostatak metode su problemi oko nekompletnog sakupljanja urina. Sakupljanje uzoraka urina tokom određenih vremenskih perioda je komplikovan postupak za bolesnike naročito ako nisu dovoljno upoznati sa načinom i svrhom prikupljanja urina. Nekompletno prikupljanje urina može dovesti do velike greške u određivanju klirensa kreatinina. Iako se klirens kreatinina svakodnevno koristi u rutinskoj praksi za dijagnostikovanje i praćenje bubrežnih bolesti kod mnogih stanja on ne odražava stvarnu JGF te je često neophodno primeniti neki precizniji test.

\subsection{VREDNOSTI KLIRENSA ${ }^{99}$ Tc-DTPA, KREATININA I CISTATINA C KOD BOLESNIKA SA RAZLIČITIM BOLESTIMA BUBREGA}

Inulin kao neizotpska supstanca koji se nakon aplikovanja kompletno filtrira $\mathrm{u}$ glomerulima i ne reapsorbuje se u tubulima predstavlja „, zlatni“ standard za pouzdano i precizno merenje JGF. Na žalost, inulin se u normalnm okolnostima ne nalazi $u$ organizmu. Zbog toga je potrebno sprovesti komplikovani postupak neprekidnog davanja inulina, da bi se stabilizovala njegova koncentracija u krvi. Tek potom je moguće početi proceduru određivanja klirensa inulina. Ovo je zametna i skupa procedura, pa se zato klirens inulina ne koristi u svakodnevnoj praksi, nego samo u istraživačke svrhe. Pored klirensa inulina primenjuje se i klirens supstanci obeleženih radioakivnim elementima.

Zbog dostupnosti, dobre korelacije sa klirensom inulina i jednostavnog merenje $u$ plazmi i urinu ${ }^{125} \mathrm{~J}$-iotalamat se preporučuje za precizno i pouzdano određivanje JGF. Jačinu glomerulske filtracije možemo proceniti i radionukleidima kao što su ${ }^{99 \mathrm{~m}} \mathrm{Tc}$ DTPA, ${ }^{99 m}$ Tc-mercaptoacetyltriglycine (MAG3) ili ${ }^{123} \mathrm{~J}$-iodohipurat, koji se inače koriste u bubrežnim imidžing tehnikama. Smatra se da je u odnosu na druge metode sa primenom radiofarmaka, ${ }^{99 \mathrm{~m}}$ Tc-DTPA relativno jeftin i dostupan, jednostavan za pripremu, dobro korelira sa klirensom inulina a bolesnik je izložen niskoj dozi radijacije. Dokazano je da ne postoje značajne razlike između izotopskih i neizotopskih metoda. Izotopske metode su reproducibilne i u visokoj korelaciji sa klirensom inulina 
kao zlatnim standardom za određivanje JGF, te je i određivanje klirensa ${ }^{99 \mathrm{~m}}$ Tc-DTPA, metoda u kojoj se koristi jedna izotopska supstanca najviše primenljivana metoda za procenu JGF u rutinskim laboratorijama (24-29).

Dinamska scintigrafija bubrega uz primenu ${ }^{99 \mathrm{~m}}$ Tc-DTPA je metoda koja se često koristi u praksi jer ne zahteva sakupljanje uzoraka krvi i urina. Poznato je da inulin klirens kao „zlatni standard" za procenu JGF ima vrlo dobro slaganje sa klirensom ${ }^{99 m}$ Tc-DTPA. Ispitivanjem međusobnog slaganja inulin klirensa i klirensa ${ }^{99 m}$ Tc-DTPA kod 51 osobe od kojih su oko $60 \%$ bili zdravi donori bubrega dobijena je statistički značajna pozitivna korelacija $\left(r=0,97 ; r^{2}=0,94 ; p<0,01\right)(102)$. Isti stepen korelacije dobijen je i kod 20 bolesnika sa hroničnom bubrežnom bolešću (103). Takođe poređenjem klirensa ${ }^{99 m}$ Tc-DTPA sa klirensom iotalamata dobijena je adekvatna korelacija (104).

Činjenica da se JGF može meriti jedino indirektno $i$ da su tehnike sa radiofarmacima skupe uz upotrebu specijalizovane opreme i da zahtevaju posebno obučeno osoblje, uslovila je pojavu čitavog niza studija čiji je cilj pronalaženje najboljeg pokazatelja JGF. Iz savremenih literaturnih podataka se vidi da postoji široko naučno interesovanje za utvrđivanje primenljivosti cistatina $\mathrm{C}$ za određivanje jačine glomerulske filtracije. Zbog male molekulske mase cistatin $\mathrm{C}$ se lako filtrira kroz bazalnu membranu glomerula i na taj način skoro se potpuno eleiminiše iz cirkulacije posle čega se u tubulima u potpunosti kataboliše i ne vraća se u cirkulaciju, što znači da njegova koncentarcija u serumu prvenstveno zavisi od jačine glomerulske filtracije pa se zato i smatra dobrim endogenim pokazateljom bubrežne funkcije odnosno JGF. Studija koja je obuhvatila 102 bolesnika sa hroničnom srčanom slabošću pokazala je da je cistatin $\mathrm{C}$ a naročito njegova recipročna vrednost podjednako dobar za procenu JGF kao i JGF određena iotalamatom uz visok stepen korelacije $(r=0,867, p<0,001)(105)$.

Ovaj rad predstavlja doprinos proučavanju pouzdanosti cistatina C kao pokazatelja jačine glomerulske filtracije u različitim grupama rizičnim za razvoj slabosti bubrega. Na taj način će biti moguće jednostavnije otkrivanje slabosti bubrega u ranom, početnom stadijumu kada je kreatinin u serumu nedovoljno osetljiv i kada su mu vrednosti još uvek u granicama normalnog.

Da bi se utvrdilo da li cistatin C može da se primeni za procenu JGF, grupi od 62 bubrežna bolesnika $(\mathrm{BB})$ sa različitim stepenom glomerulske filtracije određen je 
klirens ${ }^{99 \mathrm{~m}}$ Tc-dietilentriaminpentasirćertne kiseline ( $\left.{ }^{99 \mathrm{~m}} \mathrm{Tc}-\mathrm{DTPA}\right)$ kao i koncentracija cistatina C i kreatinina u serumu (Tabela 4). U grupi su bili bolesnici oba pola, različite životne dobi, prosečna starost bila je 45,04 \pm 12,88 godina. Ustanovili smo da su vrednosti kreatinina bile visoko statistički značajno više kod muškaraca nego kod žena $(\mathrm{p}<0,0001)$. Ovaj podatak je u potpunosti saglasan sa literaturnim podacima i opšte prihvaćenom činjenicom o polnoj zavisnosti nivoa kreatinina u krvi što se pokazalo i u drugim studijama, u kojima je takođe među polovima postojala visoko statistički značajna razlika vrednosti serumskog kreatinina $(\mathrm{P}<0,0001)(86)$.

$\mathrm{Za}$ razliku od kreatinina vrednosti klirensa ${ }^{99 \mathrm{~m}}$ Tc-DTPA se nisu statistički značajno razlikovale $u$ odnosu na pol bolesnika $(p=0,629)$. Vrednosti cistatina $C$ su bile nešto više kod muškaraca nego kod žena ali bez statističkog značaja $(p=0,226)$. Statistički se nisu razlikovale u odnosu na pol ni vrednosti $1 /$ cistatin $C(p=0,118)$ što je takođe saglasno literaturnim podacima $(31,106)$. Vrednost klirensa ${ }^{99 m}$ Tc-DTPA obrnuto, visoko statistički značajno korelira sa koncentracijom cistatina $\mathrm{C}(\mathrm{p}<0,001)$, kada sa rastom klirens ${ }^{99 \mathrm{~m}}$ Tc-DTPA najčešće opada vrednost cistatina $\mathrm{C}$ kod ispitivane grupe bubrežnih bolesnika. Utvrđena je direktna visoko statistički značajna korelacija između klirensa ${ }^{99 m}$ Tc-DTPA i recipročne vrednosti cistatina $\mathrm{C}(\mathrm{p}<0,001)$. Takođe je bila dobra korelacija i između serumskog kreatinina i cistatina C kao i klirensa ${ }^{99 \mathrm{~m}} \mathrm{Tc}-$ DTPA i serumskog kreatinina $(\mathrm{p}<0.001)$.

Primenom korelacionih testova utvrđeno je da u grupi muškaraca postoji obrnuto statistički značajno slaganje klirensa ${ }^{99 m}$ Tc-DTPA sa vrednostima cistatina $\mathrm{C}(\mathrm{p}<0,035)$, odnosno direktno, statistički značajna korelacija sa recipročnim vrednostima cistatina $\mathrm{C}$ $(p<0,049)$. Takođe klirens ${ }^{99 m}$ Tc-DTPA obrnuto statistički značajno korelira sa kreatininom u serumu muškaraca $(\mathrm{p}<0,006)$, dok cistatin $\mathrm{C}$ u serumu muškaraca direktno statistički značajno korelira sa kreatininom, $(\mathrm{p}<0,0001)$ (Tabela 6).

Kada je analizirano slaganje klirensa ${ }^{99 m}$ Tc-DTPA sa cistatinom C kod žena dobijena jejača korelacija u odnosu na muškarce $(p<0,011)$, sa porastom klirensa ${ }^{99 m}$ TcDTPA kod žena opada nivo cistatina C (Tabela 7) a raste recipročna vrednost cistatina $\mathrm{C}(\mathrm{p}<0,007)$. Kod oba pola postoji visok stepen slaganja između klirensa ${ }^{99 \mathrm{~m}}$ Tc-DTPA i cistatina $\mathrm{C}$ premda je korelacija bila jača kod žena. Slične rezultate su dobili i drugi autori ispitivanjem grupe bolesnika sa različitim bubrežnim bolestima među kojima je bilo i bolesnika na dijalizi. Iako je vrednost cistatina $\mathrm{C}$ za grupu ne dijalizarinih 
bolesnika u toj studiji bila 1,90 $\pm 0,98 \mathrm{mg} / \mathrm{l}$, dobijen je visok stepen slaganja između ${ }^{99 m}$ Tc-DTPA klirensa i $1 /$ cistatin $C(r=0,91 \mathrm{p}<0,0001)$ (107). Ispitivanjem bubrežne funkciju kod bolesnika sa ascitom dobijen je visok stepen slaganja između klirensa ${ }^{99 m}$ Tc-DTPA i cistatina $\mathrm{C}$ i zaključeno je da je cistatin $\mathrm{C}$ kod ovih bolesnika dobar pokazatelj ranog oštećenja bubrega (108). U studiji koja je obuhvatila 460 odrasle osobe dobijen je visok stepen korelacije $(r=0,853)$ između JGF i cistatina $\mathrm{C}$ za grupu ispitanika koja je imala bubrežnu bolest dok je kod zdravih ispitanika stepen korelacije bio niži (109). Iz literature je poznato da na nivo cistatina $C$ ne utiču godine života ni pol (110), što je dokazano u našem ispitivanju jer iako je sa starošću nivo cistatina $\mathrm{C}$ rastao nije utvrđena statistički značajna razlika u vrednostima cisatina $\mathrm{C}$ između starosnih grupa a nije se statistički značajno menjala sa starošću ni recipročna vrednost cistatina C (Tabela 10). Koncentracija kreatinina u serumu je rasla sa starošću ali nismo utvrdili statistički značajnu razliku u zavisnosti od starosne dobi bolesnika sa BB (Tabele 8, 11). Za razliku od kreatinina klirens ${ }^{99 \mathrm{~m}}$ Tc-DTPA se statistički značajno razlikovao po starosnim grupama, sa starošću je uglavnom opadao ali je najvišu vrednost kao i 1/cistatin C imao u starosnoj dobi od 30 do 40 godina. Poznato je da renalni klirens za jednu dekadu opadne za oko $8 \mathrm{ml} / \mathrm{min}$ kod starijih osoba što bi odgovaralo našim rezultatima kada posmatramo grupu bolesnika do 30 godina u odnosu na starosnu grupu preko 40 godina (111).

\subsection{VREDNOSTI ODREĐIVANJA KREATININA, KLIRENSA KREATININA I CISTATINA C KOD TRUDNICA}

$\mathrm{U}$ toku trudnoće dolazi do hormonskih i hemodinamskih promena koje povećavaju opterećenje bubrega pa je zbog toga izuzetno važno pratiti bubrežnu funkciju tokom graviditeta. $U$ trudnoći se povećava ekskrecija proteina tako da proteinurija može da bude rani subklinički znak poremećene bubrežne funkcije. Poremećena bubrežna funkcija u trudnoći može da dovede do čitavog niza komplikacija kao što su preeklampsija i eklampsija. Da bi se tokom trudnoće izbegle komplikacije ili smanjio njihov broj i težina, veoma je važno da se pre pojave bilo proteinurije, hipertenzije ili preeklampsije, znači što ranije, otkriju promene na bubrezima. Mogućnost ranog otkrivanja promena funkcije bubrega predstavlja veliki izazov za kliničare $\mathrm{i}$ istraživače, a odabiranje najpouzdanijeg markera bubrežne funkcije je od izuzetne važnosti. 
Ranije je konstatovano da JGF dobro odražava funkcionalno stanje bubrega pa se i tehnike i parametri za procenu funkcije bubrega zasnivaju na proceni JGF. Tradicionalni pokazatelji JGF kao što su kreatinin i klirens kreatinina nisu dovoljno osetljivi za rane promene JGF, što je kod trudnica izuzetno važno. Sama trudnoća sužava izbor najboljih markera i tehnika za procenu JGF, konkretno tehnika koje se zasnivaju na upotrebi radioaktivnih supstanci kao što su ${ }^{99 \mathrm{~m}} \mathrm{Tc}-\mathrm{DTPA},{ }^{125} \mathrm{~J}$-iothalamata, ${ }^{51}$ Cr-EDTA i drugi. Formule za procenu JGF koje su zasnovane na nivou kreatinina u serumu i koje su razvijene za negravidnu populaciju nepouzdane su kada se primene za procenu JGF kod trudnica jer smanjenje kreatinina kod trudnica nije samo posledica povećanja JGF zbog trudnoće već i hemodilucije koja dovodi do povećanja volumena plazme $(34,112)$.

Ovarijalni hormon, relaksin, povećava aktivnost vaskularne želatinize i posredno, preko azot oksida, dovodi tokom trudnoće do vazodilatacije u bubrezima. Usled toga pored vazodilatacije dolazi i do hiperfiltracije i smanjenja miogene reaktivnosti malih renalnih arterija (113). Povećana ekskrecija proteina je posledica povećane JGF, smanjene reapsorpcije u proksimalnim tubulima $\mathrm{i}$ verovatno je pod uticajem elektrostatskog naelektrisanja glomerulskog filtra $(17,18)$.

Poznato je da trudnoća utiče na patofiziološka svojstva bubrega. Normalnu trudnoću prati niz metaboličkih i funkcionalnih promena. Promene u glomerulskoj filtraciji se zapažaju već posle četiri nedelje trudnoće a takođe dolazi i do promena $\mathrm{u}$ sistemskoj hemodinamici. Utvrđeno je da tokom trudnoće u odnosu na vrednosti kod negravidnih zdravih žena dolazi do smanjenja nivoa ALT, AST, albumina, bilirubina, GGT i LDH dok je alkalna fosfataza u trudnoći u porastu uz blagi pad nivoa kalcijuma. U trudnoći takođe značajno opada nivo feritina dok je transferin u porastu. Rastu i trigliceridi i TSH a naročito je značajan porast urata i cistatina C (114). Za cistatin C je u mnogim studijama pokazano da ne zavisi od pola, starosti, težine, mišićne mase ili stanja $(92,95)$.

Istraživanje $\mathrm{u}$ ovoj tezi je $\mathrm{u}$ prvom trenutku obuhvatilo zdrave trudnice $\mathrm{u}$ različitim periodima gestacije, prosečne starosti približno 32 godina (Tabela 12). Trudnice $u$ prvom trimestru su bile značajno mlađe $u$ odnosu na trudnice $u$ ostala dva trimestra (Tabela 13).

Kreatinin se kod ispitivanih zdravih trudnica kretao u referentnom opsegu i bio je $63,5 \pm 10,07 \mu \mathrm{mol} / 1$ (Tabela 14). Bio je najniži kod trudnica u prvom trimestru, dok je najviši bio u drugom trimestru i utvrđena je statistički značajna razlika $(p<0,003)$ 
između prvog i ostala dva trimestra (Tabela 18). Smatra se da trudnice imaju niži nivo kreatinina u odnosu na negravidne žene i to po nekim autorima zbog smanjene sinteze, a po drugima zbog povećanja JGF. Smatra se da su kod trudnica normalne vrednosti kreatinina od $35 \mu \mathrm{mol} / 1$ do $72 \mu \mathrm{mol} / 1$, dok kreatinemija od $88 \mu \mathrm{mol} / 1$, koja je normalna za negravidne žene, može predstavljati znak smanjenja renalne funkcije kod trudnica (115). Neki autori smatraju da za razliku od cistatina $\mathrm{C}$ koji tokom trudnoće raste, nema značajne razlike u kreatininemiji među trimestrima $(116,117)$. U istraživanju koje je rađeno da bi se ustanovile referentne vrednosti pojedinih parametara u trudnoći, dobijene su slične vrednosti kreatinina kao u našem ispitivanju. Utvrđeno je da su $u$ odnosu na zdrave negravidne žene trudnice imale niže vrednosti kreatinina u serumu (114). Zdrave negravidne žene u našoj populaciji su imale vrednost kreatinina 71,8 \pm $8,83 \mu \mathrm{mol} / 1$ (118). U odnosu na ove vrednosti zdrave trudnice naše populacije imaju niži nivo kreatinina što se slaže sa prethodno iznetim literaturnim podacima. Prilikom upoređivanja vrednosti kreatinina u serumu kod različitih grupa pa i trudnica uvek treba imati u vidu da nivo kreatinina u serumu zavisi i od nutritivnog statusa što može da bude uzrok neslaganja različitih studija.

Da bi ispitali uticaj životne dobi na posmatrane parametre trudnice su razvrstane $u$ petogodišnje inervale (Slika 24). Statističkim testovima potvrđeno je da nivoi kreatinina u serumu zavise od životne dobi trudnica, jer je u našem istraživanju grupa trudnica koja je imala preko 40 godina imala je značajno više vrednosti kreatinina (Slika 25, Tabela 30). Najviša prosečna koncentraciju kreatinina u I trimestru je bila $63,25 \mu \mathrm{mol} / 1$ u dobnoj grupi 30-34,9 godina, a najniža je bila 55,75 $\mu \mathrm{mol} / 1 \mathrm{u}$ dobnoj grupi 35-39,9 godina, dok u drugom trimestru nije bilo razlike u vrednostima kreatinina u odnosu na životnu dob ali je ustanovljeno da je kreatinemija u trećem trimestru značajno viša kod najstarijih trudnica (Tabela 39 ).

Utvrđeno je da najmlađe trudnice na početku trudnoće imaju značajno nižu vrednost kreatinina $u$ odnosu na trudnice iste životne dobi drugog trimestra $(p<0,05)$. U sva tri trimestra vrednosti kreatinina imale su trend blagog rasta (Slika 31).

Prosečna vrednost klirensa kreatinina kod trudnica obuhvaćenih istraživanjem iznosila je 107,11_19,91 ml/min (Tabela 15). Između trimestara nije postojala statistički značajna razlika u srednjim vrednostima klirensa kreatinina (Tabela 19). U ovom ispitivanju kao i kod drugih autora je ustanovljeno je da se klirens kreatinina posle početnog povećanja u odnosu na period pre trudnoće ne menja tokom čitave gestacije (119). Od ranije je poznato da zbog hiperfiltracije raste JGF tako da dolazi i do rasta 
klirensa kreatinina $\mathrm{u}$ trudnoći. Prema nekim autorima normalne vrednosti klirensa kreatinina za nekomplikovanu trudnoću bi bile za prvi trimestar od 69 do $140 \mathrm{ml} / \mathrm{min}$, za drugi $55 \mathrm{ml} / \mathrm{min}$ do $136 \mathrm{ml} / \mathrm{min}$ i za treći $50 \mathrm{ml} / \mathrm{min}$ do $166 \mathrm{ml} / \mathrm{min}$ (120). Očigledno je da su u našoj studiji neke trudnice imale značajniju hiperfiltraciju jer je maksimalni klirens kreatinina bio 169,20 ml/min, dok je najniži bio $63 \mathrm{ml} / \mathrm{min}$.

Posmatrano $u$ odnosu na trimestre trudnoće $\mathrm{i}$ životnu dob, najviše vrednosti klirensa kreatinina zabeležene su kod trudnica u prvom trimestru koje su imale između 35 i 39,9 godina i iznosile su u proseku $126,6 \pm 15,04 \mathrm{ml} / \mathrm{min}$, a najniže su bile u drugom trimestru u dobi od 25-29,9 godina starosti i iznosile su u proseku 91,8 $\pm 16,81$ $\mathrm{ml} / \mathrm{min}$ (Tabela 40).

Očigledno je da su početkom trudnoće izraženi filtracioni procesi i da su toliko povećani da je kod ispitivanih trudnica u prvom trimestru klirens kreatinina imao trend porasta sa starošću (Slika 32). Smatra se da hiperfiltracija svoj maksimum dostiže u drugom trimestru pa iako se prosečni klirens kreatinina nije razlikovao tokom trudnoće ipak je pojedinačna najviša vrednost klirensa kreatinina bila baš u drugom trimestru. $U$ odnosu na dobne grupe klirens kreatinina u drugom i trećem trimestru imao je opadajući trend. Smatra se takođe da u normalnoj trudnoći klirens kreatinina tri nedelje pred porođaj opada do nivoa pre trudnoće $(121,122)$.

Trudnice koje su pripadale životnoj dobi od 30 do 40 godina imale su značajno više $(\mathrm{p}<0,01)$ prosečne vrednosti klirensa kreatinina (Tabela 32).

Bez obzira što se u rutinskoj praksi za praćenje funkcije bubrega široko primenjuje klirens kreatinina problem sa nekompletnim sakupljanjem urina pa samim tim i preciznim određivanjem klirensa kreatinina u trudnoći posebno dolazi do izražaja. U trudnoći značajna količina urina se zadržava u dilatiranom kolekcionom sistemu. Da bi se predupredile greške koje mogu usled toga nastati neophodna je dobra hidracija i naročito odmor pre početka prikupljanja urina.

U nastojanju da se nađe što pouzdaniji parametar bubrežne funkcije u trudnoći, $u$ ovom momentu se govori o cistatinu $\mathrm{C}$ koji smo mi ispitavali, premda su se dosta ispitivali kao potencijalni markeri JGF i drugi proteini male molekulske mase kao što su $\alpha 1$-mikroglobulin i $\beta_{2}$-mikroglobulin oba sa izvesnim ograničenjima. Serum $\alpha_{1}$ mikroglobulin, poreklom je iz jetre, vezuje se u velikom obimu za IgA i albumin pa se filtrira slobodan dok stvaranje $\beta_{2}$-mikroglobulin varira i zavisi od imunih reakcija kao deo histokompatibilnog antigen kompleksa. Ova ograničenja se ne odnose na cistatin $\mathrm{C}$ jer se on produkuje u konstantnom obimu i slobodno filtrira pa se uglavnom većina 
istraživača slaže da nivo cistatina $\mathrm{C}$ u krvi zdravih osoba ne zavisi od pola, godina i mišićne mase (31). U najnovijem istraživanju za našu populaciju zdravih žena dobijena je prosečna vrednost cistatina C $0,82 \pm 0,0952 \mathrm{mg} / \mathrm{l}$ (118). U drugim studijama koncentracije cistatina $\mathrm{C}$ je bila u opsegu od 0,49 do 0,94 mg/l i 0,65 $\pm 0,085 \mathrm{mg} / \mathrm{l} \mathrm{kod}$ negravidnih žena starosne dobi od 20 do 59 godina $(123,124)$. Sličnu vrednost cistatina C kao za našu populaciju dobili su i drugi istraživači gde je medijana bila $0,84 \mathrm{mg} / \mathrm{l}$, a opseg od $0,56 \mathrm{mg} / 1$ do $1,29 \mathrm{mg} / 1$ i nije zavisila od životne dobi (125). Takođe neki istraživači smatraju da nema razlike u vrednostima cistatina $\mathrm{C}$ među polovima pa je dobijena srednja vrednost cistatina $C$ za žene od $0,62 \pm 0,12 \mathrm{mg} / 1$ dok je za muškarce bila $0,65 \pm 0,12 \mathrm{mg} / 1$ (126). S druge strane ima autora koji su utvrdili strogu korelaciju između vrednosti cistatina C i životne dobi kod oba pola (127). Za razliku od negravidnih žena trudnice koje su ispitivane imale su prosečnu vrednost cistatina $\mathrm{C} \mathrm{u}$ serumu $0,90 \pm 0,34 \mathrm{mg} / \mathrm{l}$ i kretala se u rasponu od $0,35 \mathrm{mg} / \mathrm{l}$ do 1,93 mg/l (Tabela 16) i bile su više u odnosu na vrednosti cistatina $\mathrm{C}$ koje su dobijene u različitim studijama za negravidne žene iste životne dobi. U normalnoj trudnoći drugi autori su dobili vrednosti cistatina $\mathrm{C}$ u serumu trudnica $0,64-2,30 \mathrm{mg} / 1$ što je bila nešto viša vrednost u odnosu na onu koju smo mi dobili (128). Treba imati u vidu da vrednost cistatina C zavisi i od metode određivanja pa tako PETIA metoda daje nešto više vrednosti u odnosu na PENIA metodu (Particle-Enhanced Nephelometric Immuno-Assay) koju smo mi koristili u našem ispitivanju.

U odnosu na gestacioni period trudnice u našem istraživanju su imale značajno različite vrednosti cistatina $C$, počev od $0,69 \pm 0,16 \mathrm{mg} / 1 \mathrm{u}$ prvom preko $0,78 \pm 0,26 \mathrm{mg} / 1$ u drugom da bi u trećem trimestru imale značajno više $(\mathrm{p}<0,0001)$ vrednosti cistatina $\mathrm{C}$, 1,21 \pm 0,30 mg/l, (Tabela 19, Slika 19). Većina autora registruje u nekomlikovanoj trudnoći znatni porast cistatina $\mathrm{C}$ u odnosu na gestacioni period pa se na primer dobija pred porođaj, $0,63-1,70 \mathrm{mg} / 1 \mathrm{u}$ odnosu na $0,50-0,82 \mathrm{mg} / 1 \mathrm{u}$ drugom trimestru dok su drugi dobili srednju vrednost cistatina $\mathrm{C}$ 0,61 mg/l u drugom i $0,88 \mathrm{mg} / \mathrm{l} \mathrm{u}$ trećem trimestru (117, 129-131). Međutim ima autora koji su posle početnog povećanja cistatina $\mathrm{C}$ dobili niže posečne vrednosti cistatina $\mathrm{C}$ u drugom trimestru (119).

Ovo istraživanje je pokazalo da je starosna dob trudnica imala uticaj na nivo cistatina $\mathrm{C}$ u svim trimestrima (Tabela 37). U I trimestru najviša vrednost cistatina $\mathrm{C}$ je bila $0,74 \pm 0,12 \mathrm{mg} 1 \mathrm{u}$ dobnoj grupi $25-29.9$ godina dok je najniža bila $0,59 \pm 0,03$ mg1 u dobnoj grupi 35-39,9 godina i pri tom je razlika bila značajna $(\mathrm{p}<0,05)($ Slika 
29). U II trimestru najviša vrednost cistatina $C$ je bila $0,99 \pm 0,43 \mathrm{mg} 1 \mathrm{u}$ najstarijoj dobnoj grupi dok je najniža bila 0,64 $\pm 0,07 \mathrm{mg} 1 \mathrm{u}$ dobnoj grupi 20-24.9 godina pri tom je razlika bila značajna $(p<0,05)$ čime je pokazano da starije trudnice imaju više vrednosti cistatina $\mathrm{C}$ od mlađih. U III trimestru najviša vrednost cistatina $\mathrm{C}$ je bila $1,35 \pm 0,38 \mathrm{mg} 1 \mathrm{u}$ najstarijoj dobnoj grupi dok je najniža bila $1,0 \pm 0,32 \mathrm{mg} 1 \mathrm{u}$ dobnoj grupi 20-24,9 godina ali nije uočena značajna razlika u srednjim vrednostima cistatina C među dobnim grupama tokom trećeg trimestra $(\mathrm{p}=0,414)$. Kada su upoređeni trimestri unutar svake dobne grupe dokazano je da postoji značajna razlika prosečnih vrednosti cistatina $\mathrm{C}$ u starosnoj dobi 35-40 godina između I i II trimestra, kada cistatin C značajno raste $(\mathrm{p}<0,05)$. Poređenjem II i III trimestra dokazali smo da postoji značajna razlika vrednosti cistatina $\mathrm{C}$ u svim dobnim grupama između ovih trimestara $(\mathrm{p}<0,05)$, a takođe postoji značajna razlika prosečnih vrednosti cistatina $\mathrm{C} \mathrm{u}$ svim dobnim grupama između I i III trimestra $(p<0,05)$ i u svim trimestrima vrednosti cistatina $\mathrm{C}$ imaju trend rasta po dobnim grupama, odnosno sa starošću raste prosečna vrednost cistatina C (Slika 29).

U literaturi gotovo da nema podataka o uticaju životne dobi na nivo cistatina $\mathrm{C}$ tokom trudnoće dok postoje podaci o uticaju životne dobi na zdravu populaciju (123). Istraživanje na populaciji od 300 zdravih stanovnika Saudijske Arabije je pokazalo da cistatin $\mathrm{C}$ značajno raste u dobi preko 50 godina i kretao se prosečno $0,738 \pm 0,11 \mathrm{mg} / 1$ za dobnu grupu od 21 do 30 godina do $0,807 \pm 0,12 \mathrm{mg} / 1$ za osobe starije od 50 godina $\mathrm{i}$ pri tom je značajno viša vrednost cistatina $\mathrm{C}$ dobijena za zdravu žensku populaciju $(p<0,0001)$ ali nije bilo značajne razlike između dobnih grupa unutar ženske populacije iako je po dekadi cistatin $\mathrm{C}$ rastao od 1,3 do 1,8 \% (132). Takođe su i studije koje su uključile 8058 ispitanika životne dobi od 28 do 75 godina života pokazale da životna dob kao i pol kao nezavisni faktori utiču na nivo cistatina C u krvi (133).

Recipročne vrednosti cistatina $\mathrm{C}$ su pokazivale iste odnose $\mathrm{u}$ odnosu na trimestre $\mathrm{i}$ po dobnim grupama kao i prosečne vrednosti cistatina $\mathrm{C}$ ali su imale obrnut trend $\mathrm{tj}$. sa starošću su vrednosti opadale. Za razliku od vrednosti cistatina C koje u III trimestru nisu pokazivale značajnu zavisnost od dobne grupe, prosečna recipročna vrednost cistatina $\mathrm{C}$ je kod trudnica u dobi od 20 do 24,9 godina bila značajno viša u odnosu na prosečne recipročne vrednosti cistatina $\mathrm{C}$ u dobnim grupama 30-34,9 godina i preko 40 $(p<0,05)$. Razlog za ovo može biti i u činjenici da je u ovim grupama bilo manje trudnica što se moglo odraziti na stepen značajnosti kada se izračunavala recipročna vrednost cistatina $\mathrm{C}$. 
$\mathrm{U}$ ovom istraživanju pokazano je da u trudnoći nivo kreatinina u serumu obrnuto statistički visoko značajno korelira sa klirensom kreatinina $(\mathrm{p}<0,0001)$, dok sa porastom kreatinina u serumu opada klirens kreatinina kod trudnica. Kada su korelacije među parametrima posmatrane po trimestrima, u prvom trimestru je dobijena stroga, obrnuta korelacija između koncentracija kreatinina u serumu i klirensa kreatinina $(p<0,026)$. Kod trudnica $u$ drugom trimestu trudnoće $u$ ovom ispitivanju nije uočena značajna korelaciju između koncentracija kreatinina u serumu i klirensa kreatinina $(p=n s)$. U trećem trimestru trudnoće koncentracija kreatinina u serumu obrnuto statistički visoko značajno korelira sa klirensom kreatinina $(\mathrm{p}<0,0001)$.

Takođe je pokazano da koncentracija cistatina C u serumu trudnica direktno visoko statistički značajno korelira sa vrednostima kreatinina $(\mathrm{p}<0,0001)$, odnosno sa porastom cistatina $\mathrm{C}$ u serumu značajno raste i nivo kreatinina (Tabela 22). Pri tom kod trudnica, cistatin $\mathrm{C}$ obrnuto statistički neznačajno korelira sa klirensom kreatinina ( $p>0,05)$ odnosno sa opadanjem nivoa cistatina $\mathrm{C}$ raste klirens kreatinina, bez statističke značajnosti. Vrednosti klirensa kreatinina direktno statistički neznačajno koreliraju sa recipročnim vrednostima cistatin $\mathrm{C}(\mathrm{p}>0,05)$, sa porastom klirensa kreatinina raste recipročna vrednost cistatina $\mathrm{C}(1 /$ cistatin $\mathrm{C})$ bez statističke značajnosti. Postoje studije u kojima nije dobijena korelacija cistatina C i kreatinina tokom trudnoće odnosno koncentracija kreatinina se zavisno od gestacionog perioda nije značajno menjala (130). Ovo istraživanje je pokazalo da cistatin $\mathrm{C}$ kod trudnica ne korelira sa klirensom kreatinina. Grupa autora koja je ispitivala dvadeset trudnica takođe nije ustanovila da postoji značajan nivo povezanosti između cistatina $\mathrm{C}$ i klirensa inulina. Kod njih se tokom trudnoće nivo cistatina $\mathrm{C}$ kretao u rasponu $0,66-1,48 \mathrm{mg} / \mathrm{l}$ a posle porođaja je bio 0,72-1,26 mg/l dok su vrednosti klirensa inulina bile u opsegu 130-188 $\mathrm{ml} / \mathrm{min}$ tokom trudnoće a posle porođaja su bile $110-167 \mathrm{ml} / \mathrm{min}$ te su ustanovili da ni u jednom momentu tokom trudnoće cistatin C ne korelira sa klirensom inulina (134). Slično našim rezultaima i u studiji gde je klirens kreatinina služio kao referentni metod za procenu JGF u trudnoći se pokazala slaba korelacija klirenasa kreatinina i cistatina $\mathrm{C}$ u serumu trudnica jer je JGF tokom trudnoće ostajala nepromenjena ili je vrlo malo rasla (130). Međutim, ima istraživača koji smatraju da tokom čitave trudnoće postoji stroga korelacija između JGF i cistatina $\mathrm{C}$ i da u kasnoj trudnoći cistatin $\mathrm{C}$ u serumu trudnica odražava zapravo promene u JGF kako u normalnoj trudnoći tako i u stanju preeklampsije (90). Za razliku od naših rezultata u ispitivanju 197 trudnica različite gestacione dobi je utvrđena stroga statistički značajna korelacija klirensa kreatinina i 
cistatina $\mathrm{C}$, a takođe je utvrđena značajna korelacija cistatina $\mathrm{C}$ i gestacionog perioda što smo i mi dobili u našem istraživanju (135).

Kada su korelacije među parametrima posmatrane po trimestrimma, u prvom trimestru je dobijena direktna, značajna korelacija kreatinina u serumu sa nivoom cistatina $\mathrm{C}(\mathrm{p}<0,014)$. Takođe klirens kreatinina je bio u obrnutoj visoko značajnoj korelaciji sa koncentracijom cistatina $\mathrm{C}$ i direktnoj visoko značajnoj korelaciji sa recipročnim vrednostima cistatina $\mathrm{C}(\mathrm{p}<0,0001)$ (Tabela 23). Ovakvi rezultati su $\mathrm{u}$ skladu sa literaturnim podacima (135). Iz ROC analize se zaključuje da su specifičnost i osetljivost u prvom trimestru bili najveći za cistatin C (Slika 21).

U drugom trimestru trudnoće neki autori su dobili značajnu korelaciju između cistatina C i klirensa kreatinina uz zaključak da se cistatin C može korisiti kao marker JGF u trudnoći (135) dok su drugi dobili rezultate saglasno našim (129). Kod trudnica u drugom trimestu trudnoće i u našem ispitivanju uočena je direktna značajna korelacija nivoa kreatinina $\mathrm{u}$ serumu $\mathrm{i}$ koncentracije cistatina $\mathrm{C}(\mathrm{p}<0,004)$, tj. sa porastom kreatinina u serumu visoko značajno češće raste i nivo cistatina $\mathrm{C}$. Takođe kod trudnica u drugom trimestru trudnoće klirens kreatinina obrnuto statistički neznačajno korelira sa koncentracijom cistatina $\mathrm{C}(\mathrm{p}=\mathrm{ns})$, a direktno statistički neznačajno korelira sa recipročnim vrednostima cistatina $\mathrm{C}(\mathrm{p}=\mathrm{ns})$ (Tabela 25$)$. Iz ROC analize je utvrđeno da je specifičnost i osetljivost najveća za cistatin $\mathrm{C}$ u drugom trimestru (Slika 22). U trećem trimestru trudnoće koncentracija kreatinina u serumu obrnuto statistički visoko značajno korelira sa koncentracijom cistatina $\mathrm{C}(\mathrm{p}<0,003)$ tako da porast vrednosti kreatinina u serumu najčešće prati visoko statistički značajano porast nivoa cistatina $\mathrm{C}$, odnosno opada značajno recipročna vrednost cistatina $C$, što je u skladu sa literaturnim podacima $(128,135,136)$. Klirens kreatinina obrnuto statitstički neznačajno korelira sa koncentracijom cistatina $\mathrm{C}$ i direktno neznačajno korelira sa recipročnom vrednošću cistatina C (Tabela 27). Analizom ROC krive zaključeno je da je klirens kreatinina bez statistički značajne površine pod krivom $(p=0,868)$ dok vrednost kreatinina u serumu imaju manju specifičnost i osetljivost $u$ odnosu na cistatin $\mathrm{C}$ i 1/cistatin $\mathrm{C}$ koji imaju visoku osetljivost i specifičnost u trećem trimestru (Slika 23).

Kao što se iz literaturnih podataka vidi, a što je i u ovoj tezi dobijeno, nivo cistatina $\mathrm{C}$ u serumu je u direktnoj korelaciji sa gestacionim periodom trudnica. Drugi autori su na različite načine objašnjavali porast cistatina $C$ tokom normalne trudnoće. Svakako je povezano više faktora od endotelijaze, hormonskog uticaja preko promene u glomerulskoj filtraciji tokom trećeg trimestra. Grupa skandinavskih autora tvrdi da $\mathrm{u}$ 
normalnoj trudnoći dolazi do endotelijaze što uslovljava smanjenje veličine i naelektrisanja filtracionih pora u glomerulu, usled čega proteini male molekulske mase koji se inače normalno filtriraju ne mogu da prođu. Slično cistatinu C se u trudnoći ponašaju beta 2 -mikroglobulin i beta-trace protein (137). Nasuprot ovoj tvrdnji postoje mišljenja da je stepen endotelijaze koji je normalan tokom trudnoće suviše mali da bi rezultovao značajnim povećanjem nivoa cistatina $\mathrm{C}$ u serumu trudnica (138). Takođe neki autori su uzrok pronalazili u sintezi cistatina $\mathrm{C}$ u placenti (139), da bi isti autori narednim istraživanjima utvrdili da povećani nivo cistatina $\mathrm{C} u$ serumu trudnica ne potiče iz uteroplacentalne jedinice (140). Poznato je da cistatin C zajedno sa drugim cistatinima kao inhibitor proteinaza u organizmu učestvuje u lancu reakcija koje imaju cilj da za sebe vežu matriks metaloproteinaze (MMP-9 i MMP-2), da bi se sprečila autoliza usled aktivacije MMP (141). Mišljenja smo da do povećanja cistatina C tokom normalne trudnoće dolazi upravo zbog težnje organizma da uskladi nivo proteinaza i njihovih inhibitora da bi zaštiti fetus od destrukcije (142).

Ne postoji jedinstveni stav o stepenu korelacije klirensa kreatinina odnosno JGF i koncentracije cistatina $\mathrm{C}$ u serumu trudnica. Međutim daleko više podataka je slično našim rezultatima koji podržavaju stav da ne postoji zadovoljavajući stepen korelacije cistatina C i JGF bez obzira na izbor metode procene JGF.

\subsection{VREDNOSTI KREATININA, KLIRENSA KREATININA I CISTATINA C KOD TRUDNICA SA PIH}

Hipertenzija koja se javlja u 2-3\% tokom trudnoće je najčešći medicinski probelm kod trudnica. Prema National High Blood Pressure Education Program

Working Group on High Blood Pressure in Pregnancy hipertenzivni problemi tokom trudnoće klasifikuju se u 4 kategorije:

1. hronična hipertenzija

2.preeklampsija-eklampsija

3. preeklampsija superponirana na hroničnu hipertenziju

4. gestaciona hipertenzija (prolazna hipertenzija u trudnoći ili hronična hipertenzija otkrivena u drugoj polovini trudnoće). Javlja se obično posle 20 nedelje trudnoće 
bez proteinurije. Ova je nova terminologija ali se široko primenjuje stara terminologija: trudnoćom izazvana hipertenzija $(\mathrm{PIH})$ jer je preciznija.

Hronična hipertenzija je definisana krvnim pritiskom preko 140/90 mm Hg pre trudnoće ili pre 20. nedelje trudnoće. Kada se hipertenzija prvi put registruje kod žene pre 20 nedelje trudnoće, krvni pritisak se obično kreće ka hroničnoj hipertenziji, dok gestaciona hipertenzija prolazi posle trudnoće (143). Gestaciona hipertenzija odnosno PIH definiše se ako je krvni pritisak $\geq 140$ i/ili $\geq 90 \mathrm{mmHg}$ i javlja se kod $6-8 \%$ trudnica koje imaju hipertenziju. PIH može tokom trudnoće da dovede do preeklampsije pa je izuzetno značajno radi pravovremnog sprovđena adekvatne terapije uočiti je na vreme. Naročiti rizik od pojave PIH postoji kod žena koje su prvi put trudne, kod žena čije su majke ili sestre imale PIH, kod višestruke trudnoće kao i kod trudnica mlađih od 20 godina odnosno starijih od 40 godina života. Takođe rizik od pojave PIH postoji i kod žena koje su pre trudnoće imale bolest bubrega ili visok krvni pritisak. Poremećaji koji mogu da izazovu hipertenziju tokom trudnoće mogu da dovedu i do smrti fetusa i trudnice (144).

Gotovo jedna trećina žena kod kojih se tokom trudnoće pojavi PIH razvije sindrom preeklampsije. Preeklampsija se karakteriše povećanim krvnim pritiskom i pojavom proteinurije tokom trudnoće. Inače još uvek nisu poznati tačni patofiziološki procesi koji dovode do gestacijske hipertenzije i obično se trudnoća završava normalno. Međutim, između 1991. i 1999. godine u Sjedinjenim američkim državama 15,7\% smrti trudnica je uzrokovana PIH (145). Iz ovih razloga razumljiv je interes da se rano prepoznaju i pravovremeno počnu da prate hipertenzivne promene tokom trudnoće. Poslednjih godina ispitivan je veliki broj biohemijskih parametara koji treba da odraze rane promene koje se usled PIH dešavaju u organizmu trudnice.

Jedan od ciljeva ovog rada je bio da se odredi cistatin C kod 33 trudnice koje su u trećem trimestru imale gestacijsku hipertenziju (PIH) da bi utvrdi da li kod njih cistatin C može da bude dobar pokazatelj JGF. Prosečna starost trudnica je bila 28,91 $\pm 6,1$ godinu. Najmlađa trudnica je imala 20 godina dok je najstarija imala 44 godina. Prosečna koncentracija kreatinina u serumu ispitivanih trudnica sa PIH bila je 65,27 \pm 10,62 $\mu \mathrm{mol} / 1$, dok je prosečna vrednost klirensa kreatinina bila 103,05 ml/min uz prosečni nivo cistatina $\mathrm{C} 1,45 \pm 0,43 \mathrm{mg} / 1$ i prosečnu recipročnu vrednost cistatina $\mathrm{C}$ $0,74 \pm 0,20$ (Tabela 41). Oskudni su literaturni podaci o cistatinu C i ostalim parametrima kod trudnica sa PIH, više autora se bavilo određivanjem ovih parametra $\mathrm{u}$ 
stanju preeklampsije i eklampsije. U studiji koja je ispitivala 37 trudnica od kojih je 13 trudnica $\mathrm{u}$ trećem trimestru predstavljalo kontrolnu grupu sa prosečnim cistatinom $\mathrm{C}$ $1,12 \pm 0,16 \mathrm{mg} / \mathrm{l}$, bilo je 9 trudnica $\mathrm{u}$ trećem trimestru sa blagom preeklampsijom i prosečnim cistatinom C $1,51 \pm 0,16 \mathrm{mg} / \mathrm{l}$, dok su trudnice sa ozbiljnom preeklampsijom na početku trećeg trimestra imale cistatin C 1,43 $\pm 0,19 \mathrm{mg} / 1$ a krajem trećeg trimestra cistatin $\mathrm{C}$ je bio $1,73 \pm 0,29 \mathrm{mg} / 1$ (139). Poređenjem ovih vrednosti sa našim uočava se da se vrednost cistatina $\mathrm{C}$ kod trudnica sa PIH nalazi između vrednosti za trudnice sa nekomplikovanom trudnoćom i vrednosti za trudnice sa blagom preeklampsijom dok je kod ozbiljne preeklampsije u trećem trimestru nivo cistatina $\mathrm{C}$ bio znatno viši. Takođe su i drugi autori uočili značajnu razliku u vrednostima cistatina $\mathrm{C}$ u normalnoj trudnoći u odnosu na trudnice sa preeklampsijom (147). Utvrđeno je takođe da značajniji porast cistatina $\mathrm{C}$ u ranom stadijumu trudnoće može da bude pokazatelj rizika za kasniji razvoj PIH odnosno preeklampsije (148).

Ispitivanje međusobne korelacije posmatranih parametara trudnica sa PIH pokazalo je da su odnosi među njima slični kao u trećem trimestru nekomplikovane trudnoće. Nismo utvrdili značajnu korelaciju vrednosti kreatinina u serumu sa vrednostima cistatina $\mathrm{C}$, a takođe i klirens kreatinina obrnuto statistički neznačajno korelira sa cistatinom $\mathrm{C}$ i direktno statistički neznačajno korelira sa 1/cistatin C. Nije potvrđena veza između cistatina $\mathrm{C}$ i kreatinina, ni između cistatina $\mathrm{C}$ i klirensa kreatinina. Utvrdili smo jedino značajnu povezanost između kreatinina u serumu i klirensa kreatinina $(\mathrm{p}<0,017)($ Tabela 42).

Poređenjem vrednosti koje su dobijene za kreatinin, klirens kreatinina, cistatin C i recipročnu vrednost cistatina $\mathrm{C}$ kod trudnica koje su bile u trećem trimestru i imale PIH sa vrednostima kod trudnica u trećem trimestru nekomplikovane trudnoće zaključili smo da su se jedino vrednosti cistatina $\mathrm{C}$ i recipročne vrednosti cistatina $\mathrm{C}$ značajno razlikovale između ove dve posmatrane grupe $(\mathrm{p}<0,004)$ (Tabela 43). Ove rezultate je potvrdila i ROC kriva (Slika33). I drugi istraživači su utvrdili značajnu vezu između cistatina $\mathrm{C}$ u trećem trimestru kod trudnica sa hipertenzivnim komplikacijama a da se pri tom vrednost kreatinina nije značajno menjala (149).

Utvrđeno je takođe da veći porast cistatina $\mathrm{C}$ kao i beta-2-mikroglobulina već tokom drugog trimestra mogu da nagoveste hipertenzivne komplikacije $\mathrm{u}$ daljem toku trudnoće i da budu potencijalni prediktivni marker preeklampsije (150). Ispitujući uticaj životne dobi trudnica na posmatrane parametre zaključeno je da iako su mlađe 
trudnice imale niže prosečne vrednosti kreatinina u serumu nije bilo značajne razlike među dobnim grupama u vrednostima kreatinina (Tabela 45). LSD testiranjem dokazano je da životna dob trudnica sa PIH ne utiče na vrednost kreatinina (Tabela 46). Slične vrednosti su dobijene i za trudnice trećeg trimestra nekomlikovane trudnoće.

Najviša vrednost klirensa kreatinina je bila 153,6 ml/min i zabeležena je kod trudnice iz dobne grupe 20 - 24,9 dok je najniži klirens imala trudnica iz dobne grupe 25 - 29,9 godina. Trudnice sa PIH koje su imale preko 35 godina imale su najniže prosečne vrednosti klirensa kreatinina i značajno su se razlikovale u odnosu na vrednosti za dobnu grupu 30 - 34,9 godina (Tabela 48). Kod ostalih starosnih grupa vrednosti klirensa kreatinina su bile približne (Slika 36).

Kod trudnica sa PIH najniža vrednost cistatina $C$ je dobijena za trudnicu koja pripada dobnoj grupi 20 - 24,9 godina i iznosila je 0,86 mg/l dok je najviša koncentracija cistatina $\mathrm{C}$ u serumu iznosila $2,54 \mathrm{mg} / \mathrm{l}$ i dobijena je za trudnicu koja je starija od 35 godina. Zaključili smo da sa starošću raste nivo cistatina C (Tabela 49). Vrednosti cistatina $\mathrm{C}$ kod trudnica sa PIH su se značajno razlikovale u odnosu na životnu dob $\mathrm{i}$ to tako da su trudnice sa PIH koje pripadaju dobnoj grupi od $20-24,9$ godina u odnosu na trudnice od $30-34,9(\mathrm{p}<0,05)$ i starije od 35 godina imale značajno niže vrednosti $(\mathrm{p}<0,005)($ Slika 37). Već je rečeno da životna dob kod trudnica sa hipertenzivnim poremećajima predstavlja faktor rizika (144). Slični odnosi su dobijeni i za recipročnu vrednost cistatina $\mathrm{C}$ kod trudnica sa $\mathrm{PIH}$ odnosno dokazano je da sa starenjem opada značajno srednja recipročna vrednost cistatina $(\mathrm{p}<0,05)$ (Tabela 51, Slika 38).

Porast cistatina $\mathrm{C}$ tokom trudnoće a naročito pred porođaj kao i u hipertenzivnim komplikacijama kao što je PIH i preeklampsija neki istraživači objašnjavaju promenama u bubrežnom prometu proteina. Kao mogućnost se navodi i povećanje sinteze i sekrecije proteina tokom trudnoće (151). Takođe ima istraživača koji smatraju da povećanje cistatina $\mathrm{C}$ tokom trudnoće i preeklampsije dolazi usled njegove sinteze u placenti mada nije dokazana povezanost težine posteljice i koncentracije cistatina $\mathrm{C}$ a dokazano je $\mathrm{i}$ da ne postoji transport cistatina $\mathrm{C}$ kroz placentu (139). Poznato je i da je nivo cistatina $\mathrm{C} \mathrm{u}$ krvi fetusa znatno viši od vrednosti u krvi majke (128). S druge strane u amnionskoj tečnosti cistatin $\mathrm{C}$ se nalazi u znatno manjoj količini od one u krvi fetusa i krvi majke i tokom trudnoće dolazi do smanjenja njegovog nivoa (152). Smatra se da se zapravo mehanizmi preeklampsije i ne razlikuju suštinski od normalne trudnoće već da je preeklampsija samo na ekstremnom kraju kontinuiranog spektra zapaljenskih reakcija 
koje su uslovljene samom trudnoćom, odnosno da preeklampsija nastaje kao prekomeran intravaskularni inflamatorni odgovor na trudnoću. Taj odgovor može da bude preteran i uključuje aktivaciju urođenog i adaptivnog imuno sistema (153). Još pre dve decenije je pokazano da kod trudnica sa PIH postoji aktivacija neutrofila koja je ograničena na cirkulaciju majke i usled koje dolazi do oštećenja krvnih sudova (154). U prilog ovoj teoriji govore i modeli sa pacovima kojima je izazvan PIH nakon čega su im farmakološki suprimirani limfociti, što je rezultovalo poboljšanjem pritiska i endotelne funkcije (155). Međutim inflamacija može, pored drugih višestrukih uzroka, da bude razlog za preeklampsiju u trudnoći ali i ne jedini i dovoljan uzrok (156).

Korelacija cistatina C sa JGF potpuno je drugačija kod negravidnih žena u odnosu na gravidne. Takođe i kod trudnica sa PIH i peeklampsijom nije utvrđena korelacija između cistatina $\mathrm{C}$ i JGF što govori u prilog činjenici da su procesi glomerulske filtracije potpuno drugačiji u trudnoći. Neki autori ovu pojavu objašnjavaju prisustvom znatnog stepena endotelijaze usled čega dolazi do tzv. oticanja glomerula usled čega im se menja promer kao i naelektrisanje, što uslovljava smanjenu filtraciju pozitivno naelektrisanog cistatina $\mathrm{C}$ dok negativno naelektrisan manji molekul albumina prolazi $\mathrm{u}$ većem obimu (137). Endotelijaza je u različitom stepenu prisutna i u normalnoj trudnoći i u gestacionoj hipertenziji i ne može se smatrati dijagnostičkim kriterijumom preeklampsije ali može da predstavlja vezu na putu pretvaranja normalne trudnoće $u$ preeklampsiju. Određivanje cistaina $\mathrm{C}$ u serumu može da bude korisno u praćenju trudnoće, dijagnozi PIH i preeklampsije kao i za praćenje glomerulske filtracije jer je on stabilan pokazatelj filtracionih procesa. Svakako su povezani različiti faktori od endotelijaze, hormonskog uticaja preko promene u glomerulskoj filtraciji tokom trećeg trimestra i u preeklampsiji. Rast cistatina C tokom trudnoće se može sagledati kao posledica napora organizma trudnice da uskladi odnos proteaza i njihovih inhibitora (157), jer je održavanje ravnoteže ovog kompleksa izuzetno značajno kako u periodu placentacije tako i dalje tokom razvoja trudnoće u cilju sprečavanja gubitka ploda. Neophodno je daljim ispitivanjima tačno definisati vrednosti cistatina $\mathrm{C}$ zavisno i od starosne dobi trudnica. 


\subsection{VREDNOSTI KREATININA, KLIRENSA KREATININA I CISTATINA C KOD BOLESNIKA SA BALKANSKOM ENDEMSKOM NEFROPATIJOM}

Endemska nefropatija je bolest bubrega koja ima progresivni i hronični karakter. To je porodična bolest koja može da obuhvati više generacija i rasprostranjena je u slivu reke Dunav, zemljama jugostočne Evrope, Rumuniji, Bugarskoj i na prostorima bivše Jugoslavije, gde predstavlja veliki zdravstveni problem već više decenija. Početna istraživanja su pokazala da je bolest povezana sa seoskim načinom života uz tvrdnju da ne pogađa autohtono gradsko stanovništvo a takođe je poznato da doseljenici mogu da obole ukoliko u endemskom mestu provedu dovoljno dugo vremena kao i da napuštanje endemskog žarišta u ranom životnom dobu može da spreči nastanak bolesti. Na osnovu ovoga su ispitivane brojne teorije nastanka bolesti gde se kao uzrok navode i toksini iz različitih rodova buđi (158). Jedna od teorija dovodi BEN u vezu sa oboljenjem sličnog kliničkog toka koje nastaje usled korišćenja biljki iz roda Aristolochia a naziva se kineska biljna nefropatija $(\mathrm{CHN})$. Aristolohinska kiselina ima nefrotoksična, kancerogena i mutagena svojstva. Aristolohinska kiselina se nalazi u biljakama kao što su kopitnjak i vučja jabučica kao i u drugim biljkama iz ove familije koje se koriste u tradicionalnoj kineskoj medicini kao i u zapadnoj medicini u biljnim preparatima za mršavljenje (159). Pretpostavlja se da dolazi do kontaminacije brašna od koga se $u$ kućnim uslovima pravi hleb, semenima iz zaražene zemlje pa usled dovoljno duge upotrebe može doći do pojave bolesti što bi objasnilo regionalni karakter bolesti (160). Takođe hronična izloženost štetnom dejstvu aristolohinske kiseline može da dovede do pojave uroepitelnog karcinoma kod obolelih od EN (161). Uprkos obimnim istraživanjima i naporima da se reše brojni problemi kao što su rana dijagnostika i prevencija bolesti kao i udruženost bolesti sa tumorima gornjeg urotelijuma, etiologija EN ostaje još uvek nejasna (162). Dalja istraživanja BEN treba da budu usmerena na ispitivanje incidence $\mathrm{i}$ prevalence bolesti $\mathrm{u}$ žarištima kao $\mathrm{i}$ na ispitivanje patomorfoloških karakterisitka savremenim metodama (163).

Kod osoba obolelih od endemske nefropatije registrovani su brojni funkcionalni poremećaji koji u ranom stadijumu ukazuju na poremećaj tubulskih funkcija. Često su ovi bolesnici imali smanjenu jačinu glomerulske filtracije pa ponekad i izraženu bubrežnu insuficijenciju. Jačina glomerulske filtracije najčešće je određivana merenjem klirensa endogenog kreatinina. Određivanje JGF i efektivnog protoka plazme merenjem klirensa Tc-DTPA i J-hipurana kod zdravih osoba iz porodica sa endemskom 
nefropatijom i kod bolesnika sa tumorima gornjeg urotelijuma pokazalo je da zdrave osobe iz endemskog područja imaju smanjen protok plazme što bi mogao da bude veoma rani poremećaj koji prethodi promeni glomerulske filtracije i oštećenja tubula (164). Dijagnoza BEN se postavlja kod osoba iz endemskih naselja korišćenjem dijagnostičkih kriterijuma koji uključuju epidemiološke kriterijume, proteinuriju generalno $<1 \mathrm{~g} / 24 \mathrm{~h}$, mikroalbuminuriju, tubulske markere i pad nivoa glomerulske filtracije kao i isključivanje ostalih bubrežnih oboljenja (165).

Radi ispitivanja da li se cistatin $\mathrm{C}$ može uspešno korisititi za rano otkrivanje poremećaja JGF kod obolelih od endemske nefropatije ispitana je grupa od 26 muškaraca i 31 žene koji su imali BEN (Slika 39). Prosečna starost ispitivanih osoba bila je 68,9 \pm 9,6 godina. Najmlađi bolesnik je imao 45 godina dok je najstariji imao 83 godine i ujedno je postojala statistički značajna razlika u godinama bolesnika $(p<0,05)$. Dobijeni rezultati govore $\mathrm{u}$ prilog izrazitijem pomeranju oboljevanja ka starijim uzrastima i izmenjenom toku bolesti jer su prva klinička istraživanja sredinom dvadesetog veka ukazivala na najveće oboljevanje između treće i pete decenije života.

Bolesnici sa BEN su imali prosečne vrednosti klirensa kreatinina 103,85 $\pm 48,05$ $\mathrm{ml} / \mathrm{min}$, i vrednost se kretala od $11,7 \mathrm{ml} / \mathrm{min}$, do $203 \mathrm{ml} / \mathrm{min}$. Povećanje klirensa kreatinina u početku bolesti opisali su i drugi autori iako su kod bolesnika sa BEN našli da su bubrezi simetrično smanjeni (166). Srednja vrednost kreatinina bila je 170,42 \pm $150,79 \mu \mathrm{mol} / 1$ i kretala se od najniže $60 \mu \mathrm{mol} / 1$ do najviše $858 \mu \mathrm{mol} / \mathrm{l}$. Ujedno je prosečna vrednost cistatina $C$ bila $1,94 \pm 1,25 \mathrm{mg} / 1$ i pri tom je najniža vrednost bila $0,76 \mathrm{mg} / \mathrm{l}$ a najviša $6,31 \mathrm{mg} / \mathrm{l}$. Prosečna recipročna vrednost cistatina $\mathrm{C}$ je kod bolesnika sa BEN bila $0,70 \pm 0,33$ uz najnižu vrednost 0,16 i najvišu 1,32.

Ispitivanjem uticaja starosti bolesnika sa BEN na dobijene vrednosti kreatinina, klirensa kreatinina i cistatina $\mathrm{C}$ u serumu utvrđeno je da ne postoji statistički značajna povezanost između starosti ovih bolesnika i klirensa kreatinina $(p=0,8)$. Takođe ne postoji statistički značajna povezanost između starosti bolesnika sa BEN i cistatina $\mathrm{C}$ $(p>0,05)$ dok je utvrđeno da sa starošću statistički visoko značajno raste nivo kreatinina u serumu bolesnika sa BEN ( $p<0,005)$ što su dobili i drugi istraživači (167).

Bolesnici sa BEN su u ovom radu podeljeni u četiri grupe zavisno od vrednosti klirensa kreatinina kao pokazatelja jačine glomerulske funkcije. U prvu grupu su izdvojeni bolesnici sa vrednostima klirensa kreatinina do $39,9 \mathrm{ml} / \mathrm{min}$, u drugu sa vrednostima klirensa od $40 \mathrm{ml} / \mathrm{min}$ do 79,9 $\mathrm{ml} / \mathrm{min}$, treća od $80 \mathrm{ml} / \mathrm{min}$ do $119,9 \mathrm{ml} / \mathrm{min}$ a četvrtu grupu sačinjavali su bolesnici sa vrednostima klirensa preko $120 \mathrm{ml} / \mathrm{min}$. 
Između I i III, I i IV, II i III, II i IV grupe postojala je značajna razlika u srednjim vrednostima klirensa kreatinina $(p<0,01)$ a takođe i između I i II, kao i III i IV grupe ispitanika $(\mathrm{p}<0,05)($ Slika 43).

Prosečna starost bolesnika približno je ista kod osoba koje pripadaju prvoj $(73,2 \pm$ 8,8 godina) i drugoj grupi (73,12 godina), dok je prosečna starost značajno niža u trećoj $(61,2 \pm 9,7$ godina $),(p<0,001)$ i četvrtoj grupi $(64,1 \pm 9,9$ godine $)(p<0,05)$, u odnosu na prvu i drugu grupu bolesnika (Slika 41). Stariji bolesnici su imali veći stepen oštećenja funkcije bubrega što je saglasno podacima drugih autora koji su dobili da je prosečna starost bolesnika sa BEN koji su na hemodijalizi 72,5 godina $(168,169)$.

Bolesnici sa BEN čiji je klirens kreatinina bio manji od $40 \mathrm{ml} / \mathrm{min}$, imali su srednje vrednosti kreatinina 345,5 $\pm 140,45 \mu \mathrm{mol} / 1$, i pokazali smo da je ta vrednost značajno viša $u$ odnosu na ostale grupe bolesnika sa BEN $(p<0,01)$. Bolesnici u drugoj grupi su imali srednju vrednost kreatinina $170,05 \pm 74,96 \mu \mathrm{mol} / \mathrm{l}$ i ta vrednost je bila značajno različita $u$ odnosu na ostale posmatrane grupe bolesnika $(p<0,01)$. Srednju vrednost kreatinina od $100,3 \pm 47,97 \mu \mathrm{mol} / 1$ imali su bolesnici iz treće grupe sa vrednostima klirensa kreatinina između $80 \mathrm{ml} / \mathrm{min}$ i 119,9 $\mathrm{ml} / \mathrm{min}$ (Tabela 53). Ispitanici iz četvrte grupe gde su vrednosti klirensa kreatinina više od $120 \mathrm{ml} / \mathrm{min}$ imali su prosečne vrednosti kreatinina 83,4 $\pm 31,46 \mu$ mol/1 i između III i IV grupe nije bilo statistički značajne razlike u vrednostima kreatinina u serumu bolesnika sa BEN $(\mathrm{p}>0,05)$ (Slika 42). Iako su u IV grupi bolesnici imali srednju vrednost kreatinina u referentnom opsegu postojali su klinički znaci bolesti.

$\mathrm{U}$ ovom istraživanju dobijeno je da je prosečna vrednost cistatina $\mathrm{C}$ u prvoj grupi bolesnika sa BEN bila 3,68 mg/l dok je srednja vrednosti cistatina $\mathrm{C}$ kod bolesnika u drugoj grupi bila 2,23 mg/l. U trećoj grupi bolesnika sa BEN srednja vrednost cistatina Cje bila 1,26 mg/l. Ispitanici u četvrtoj grupi su imali srednju vrednost cistatina C 1,13 $\mathrm{mg} / \mathrm{l}$ pri tom je najniža bila $0,78 \mathrm{mg} / 1$ a najviša $1,69 \mathrm{mg} / \mathrm{l}$ (Slika 44). Ujedno je utvrđeno da postoji statistički značajna razlika između prve i svih ostalih grupa u vrednostima cistatina $\mathrm{C}, \mathrm{p}<0,01$. Između druge $\mathrm{i}$ četvrte grupe postoji statistički značajna razlika, $(p<0,05)$ dok nema statistički značajne razlike između druge i treće, kao i treće i četvrte grupe ispitanika $(\mathrm{p}>0,05)$. Srednja recipročna vrednost cistatina $\mathrm{C}$ kod bolesnika u prvoj grupi iznosila je 0,407 dok je u drugoj grupi bila 0,49 a u tećoj grupi srednja recipročna vrednost cistatina $\mathrm{C}$ je bila 0,92 . Srednja recipročna vrednost cistatina $\mathrm{C}$ u četvrtoj grupi je iznosila 0,93 (Slika 45). Do sada nije bilo zapaženijih radova koji su ispitivali 
povezanost $\mathrm{BEN}$ i cistatina $\mathrm{C}$ već je većina autora bila usmerena ka ispitivanju oštećenja tubula u ovoj bolesti.

Kako postoji značajna razlika u srednjim vrednostima klirensa kreatinina u svim grupama bolesnika sa BEN a nije utvrđena značajna razlika u srednjim vrednostima cistatina C između III i IV grupe bolesnika stiče se utisak da cistatin C u odnosu na klirens kreatinina u ovom slučaju nije dovoljno osetljiv za procenu JGF. Međutim, bez obzira što se međusobno nisu značajno razlikovale srednje vrednosti cistatina $\mathrm{C}$ između III i IV grupe bolesnika, tj. onih sa klirensom kreatinina preko $80 \mathrm{ml} / \mathrm{min}$, dobijene vrednosti su više u odnosu na vrednosti koje su drugi autori dobili za zdravu opštu populaciju osoba starijih od 50 godina $(114,123)$. Slične vrednosti su dobijene i za našu zdravu populaciju (118). Ova činjenica kao i saznanje da početkom bolesti počinje progresivno da se smanjuje veličina bubrega i broj nefrona pa samim tim i opada JGF, a da se klirens kreatinina zadržava u normalnom opsegu kandiduje cistatin $\mathrm{C}$ kao rani marker u otkrivanju početka bolesti. Ovo je naročito značajno u cilju skrininga porodica sa BEN da se blagovremeno uoči promena u funkciji bubrega. Ispitivanje stanovništva u cilju ranog otkrivanja početka bolesti primenom MDRD formule za izračunavanje JGF, poređenjem endemičnih i neendemičnih regiona nije pokazalo dovoljnu dijagnostičku pouzdanost za procenu ranog početka bolesti (170). Neki autori su pokušavali da praćenjem mikroalbuminurije definišu pouzdan početak bolesti, međutim pokazalo se iako su povišene vrednosti mikroalbumina u urinu rasle sa smanjenjem bubrežne funkcije, odnosno padom klirensa kreatinina, srednja vrednost mikroalbuminurije nešto iznad gornje referentne vrednosti, zabeležena je čak i kod osoba sa klirensom kreatinina izmedju 80 i $120 \mathrm{ml} / \mathrm{min}$, dok je srednja vrednost mikroalbuminurije kod osoba sa klirensom preko $120 \mathrm{ml} / \mathrm{min}$, bila u granicama referentnih vrednosti (171).

Imajući sve ovo u vidu nivo cistatin $\mathrm{C}$ bi uz dodatna ispitivanja mogao ipak da predstavlja pouzdan marker poremećaja bubrežne funkcije bolesnika sa BEN. 


\subsection{UTICAJ PROTEINURIJE NA KONCENTRACIJU CISTATINA C U SERUMU BOLESNIKA SA NEFROTSKIM SINDROMOM}

Nefrotski sindrom predstavlja skup znakova i simptoma koji se obično povezuju sa određenim glomerulskim bolestima. Nefrotski sindrom nastaje usled povećane propustljivost bazalne membrane glomerula za albumine i druge makromolekule srednje i velike molekulske mase. Klinički se prezentuje pojavom protenurije, hipoalbuminemijom, pojavom otoka kao i hiperlipidemijom i mogućom lipidurijom. Takođe dolazi i do hiperkoagulabilnosti krvi. Za nefrotski sindrom je karakteristična proteinurija preko $3,5 \mathrm{~g}$ na dan. Usled gubitka proteina njihov nivo u krvi je manji od 55 g/ dok je nivo albumina manji od $25 \mathrm{~g}$ 1. Pojava edema u nefrotskom sindromu je u vezi sa hipoalbumienijom koja dovodi do smanjenja onkotskog pritiska plazme usled čega dolazi do prelaska tečnosti iz krvnih sudova u intersticijum. Nastala hipovolemija i smanjen protok krvi kroz bubreg aktiviraju sistem renin-angiotenzin-aldosteron što usled zadržavanja vode i natrijuma dovodi do edema. Nefrotski sindrom mogu da prate akutne i hronične bolesti kao i razne komplikacije. Smanjenje albumina u krvi ovih bolesnika nizom povezanih uticaja dovodi do tromboze renalnih vena, što predstavlja jednu od ozbiljnih komplikacija nefrotskog sindroma. Komlikacije NS su i hipertezija, akutna reverzibilna bubrežna insuficijencija, endokrinološki poremećaji, pojava metala $\mathrm{u}$ tragu i povećana sklonost ka infekcijama usled smanjenog nivoa imonoglobulina $\mathrm{u}$ krvi, nepotpunog imunološkog odgovora i niza drugih razloga.

Nefrotski sindrom može da pogodi sve starosne dobi. Češće se javlja kod muškaraca nego kod žena. Kod dece se najčešće javlja između 2. i 6. godine života.

U početku je nefrotski sindrom često vrlo podmukao tako da je funkcija bubrega $\mathrm{u}$ vreme prezentacije bolesti njačešće normalna. Međutim, dalji tok bolesti dobija težak oblik pa je značajno ranim, pouzdanim markerima otkriti bolest u samom početku dok je funkcija bubrega u najvećem procentu očuvana.

Da bi utvrdili da li cistatin C može da bude dobar pokazatelj JGF kod bolesnika sa

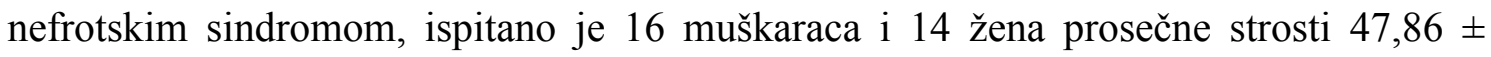
14,23 godine koji su bolovali od ove bolesti i imali su prosečnu proteinuriju 6,39 $\pm 2,95$ g/24 sata, (Slika 46). Najmlađi bolesnik bila je žena i imala je 24 godine dok je najstariji bolesnik bio muškarac i imao je 73 godine.

Uporedo je ispitana i kontrolna grupa koju je činilo 15 zdravih osoba od kojih je bilo 6 muškaraca i 9 žena, prosečne starosti 35,86 \pm 9,83 (Slika 47). Najmlađi ispitanik 
je imao 18 godina i bio je iz grupe muškaraca dok je najstariji ispitanik bila žena i imala je 58 godina. Prosečan nivo kreatinina u serumu bolesnika sa nefrotskim sindrom bio je $114,70 \pm 41,45 \mu \mathrm{mol} / 1$ dok je u kontrolnoj gupi iznosio 85,34 $\pm 7,45 \mu \mathrm{mol} / 1$. Bolesnici sa nefrotskim sindromom su imali statistički značajno više vrednosti kreatinina $u$ serumu u odnosu na kontrolnu grupu $(\mathrm{p}<0,05)($ Tabela 54).

Prosečna vrednost klirensa kreatinina je bila 75,90 $\pm 29,68 \mathrm{ml} / \mathrm{min}$ kod bolesnika sa nefrotskim sindromom, i bila je statistički značajno niža $(p<0,05)$, u odnosu na vrednost dobijenu za kontrolnu grupu koja je iznosila 99,29 $\pm 13,74 \mathrm{ml} / \mathrm{min}$.

Bolesnici sa nefrotskim sindromom su imali prosečnu vrednost cistatina $\mathrm{C} \mathrm{u}$ serumu $1,45 \pm 0,62 \mathrm{mg} / \mathrm{l}$, dok je u kontrolnoj grupi prosečna vrednost cistatina $\mathrm{C}$ bila $0,82 \pm 0,11 \mathrm{mg} / 1$ što predstavlja statistički značajnu razliku među grupama $(\mathrm{p}<0,05)$. Pri istoj proteinuriji $(6,4 \mathrm{~g} / 24$ sata) i sličnoj životnoj dobi bolesnika sa nefrotskim sindromom, drugi istraživači su dobili nešto niže vrednosti za kreatinin i cistatin $\mathrm{C} \mathrm{u}$ serumu, $101 \mu \mathrm{mol} / 1$ (42 - 368) i 1,14 mg/l (0,56 - 4,00) (172). Ispitivanje cistatina $\mathrm{C}$ kod dece sa nefrotskim sindromom pokazalo je da je $\mathrm{u}$ odnosu na kontrolnu grupu zdrave dece vrednost cistatina $\mathrm{C}$ statistički značajno viša kod dece sa nefrotskim sindromom, dok nije ustanovljena statistički značajna razlika u vrednostima serumskog kreatinina među posmatranim grupama (173). Deca koja su bolovala od različitih bubrežnih bolesti među kojima je bio i nefrotski sindrom imala su normalan nivo kreatinina dok je cistatin $\mathrm{C}$ u serumu bio blago povećan u odnosu na gornji referentni interval (174). Srednje vrednosti cistatina C kod bolesnika koji su bolovali od primarnog glomerulonefritisa i koji su imali različiti stepen proteinurije, bile su $\mathrm{u}$ granici normalnih vrednosti s tim što su kod bolesnika sa proteinurijom većom od $\geq 3,5$ $\mathrm{g} / 24 \mathrm{~h}$ bile oko gornje granice referentnog opsega. Između ispitivanih grupa nije bilo statistički značajne razlike $(\mathrm{p}>0,05) \mathrm{u}$ vrednostima koncentracije cistatina $\mathrm{C}$ u serumu. Ispitivanjem su obuhvaćeni samo bolesnici čiji je klirens kreatinina bio veći od 80 $\mathrm{ml} / \mathrm{min}(175)$. U ovom ispitivanju prosečna recipročna vrednost cistatina $\mathrm{C}$ je kod bolesnika sa nefrotskim sindromom bila $0,79 \pm 0,29$ i bila je statistički značajno niža $u$ odnosu na prosečnu recipročnu vrednost cistatina $\mathrm{C}$ u kontrolnoj grupi koja je iznosila $1,27 \pm 0,23(\mathrm{p}<0,05)$.

Da bi ispitali uticaj životne dobi bolesnika sa nefrotskim sindromom na nivo kreatinina u serumu, klirensa kreatinina i cistatina $\mathrm{C}$ bolesnici su grupisani prema 
životnoj dobi u tri grupe. Prvu grupu je činilo 9 bolesnika mlađih od 40 godina, prosečne starosti $30,14 \pm 3,28$ godina.

U drugoj grupi je bilo najviše bolesnika 13 (43\%), životne dobi od 40 do 60 godina sa prosečnom starošću 48,46 $\pm 3,18$ godina. Treću grupu je činilo 8 bolesnika starijih od 60 godina prosečne starosti $66,86 \pm 3,79$ godina (Sika 48). U sve tri grupe proteinurija je bila približno istih vrednosti.

Najvišu prosečnu vrednost kreatinina u serumu 127,16 $\pm 40,99 \mu \mathrm{mol} / 1$, imali su bolesnici koji su bili u životnoj dobi od 40 - 60 godina, dok su najmlađi i najstariji posmatrani bolesnici imali približno jednake prosečne vrednosti kreatinina u serumu (Tabela 55).

Primenom korelacionih testova nije ustanovljena statistički značajna razlika vrednosti kreatinina bolesnika sa nefrotskim sindromom $\mathrm{u}$ odnosu na životnu dob $(\mathrm{p}>0,05)($ Slika 49).

Najvišu prosečnu vrednost klirensa kreatinina 92,23 ml/min, imali su bolesnici koji su pripadali grupi do 40 godina života. Bolesnici srednje i starije životne dobi imali su približno jednake vrednosti klirensa kreatinina (Slika 50).

Primenom korelacionih testova ustanovljena je statistički značajna razlika vrednosti klirensa kreatinina bolesnika sa nefrotskim sindromom u odnosu na životnu dob, tako da bolesnici mlađi od 40 godina imaju statistički značajno više prosečne vrednosti klirensa kreatinina $\mathrm{u}$ odnosu na bolesnike srednje životne dobi $(\mathrm{R}=0,889$ $\mathrm{p}<0,05)$ i bolesnike najstarije životne dobi $(\mathrm{R}=-0,986 \mathrm{p}<0,0001)$.

Nije bilo statistički značajne razlike između vrednosti klirensa kreatinina bolesnika srednje životne dobi u odnosu na najstarije bolesnike sa nefrotskim sindromom $(\mathrm{p}>0,05)$. Kod bolesnika sa nefrotskim sindromom zbog povećane tubulske sekrecije kreatinina modifikovana MDRD jednačina za procenu JGF precenjuje vrednosti JGF kada se porede sa klirensom inulina (176). Količina proteina izlučenih urinom kod bolesnika sa NS određuje stepen težine bolesti, dok je klirens kreatinina pokazatelj gubitka JGF jer veći stepen proteinurije dovode do bržeg opadanja JGF. Tubulska sekrecija kreatinina ograničava značaj klirensa kreatinina pa su nužni bolji pokazatelji JGF kod bolesnika sa značajnijim stepenom proteinurije (177).

Prosečna vrednost cistatina $\mathrm{C}$ u serumu bila je najviša, $1,53 \mathrm{mg} / \mathrm{l}$, kod bolesnika mlađih od 40 godina, najniža, 1,16 mg/l, kod bolesnika od 40 - 60 godina (Tabela 55), a kod starijih od 60 godina bila je 1,34 mg/l (Slika 51). Korelacionim testovima nije 
ustanovljena statistički značajna razlika vrednosti cistatina C kod bolesnika sa nefrotskim sindromom u odnosu na životnu dob $(\mathrm{p}>0,05)$.

Kod bolesnika sa nefrotskim sindromom prosečne recipročne vrednosti cistatina $\mathrm{C}$ su bile najniže u grupi mlađih od 40 godina, 0,74 i bile su vrlo slične vrednostima kod najstarijih bolesnika, 0,79. U grupi srednje životne dobi prosečne recipročne vrednosti cistatina $\mathrm{C} 0,95$ su najviše.

Korelacionim testovima nije ustanovljena statistički značajna razlika recipročnih vrednosti cistatina $\mathrm{C}$ bolesnika sa nefrotskim sindromom $\mathrm{u}$ odnosu na životnu dob $(\mathrm{p}>0,05)$ (Slika 52).

Studija koja je obuhvatila 254 dece sa različitim bolestima bubrega, među kojima je i nefrotski sindrom, je za razliku od rezultata koja je dobijena u studiji za kontrolnu grupu pokazala da je procena JGF upotrebom jednačine na bazi cistatina $\mathrm{C}$ znatno osetljivija u odnosu na vrednosti JGF koje su dobijene upotrebom Schwartzove formule. Preko $50 \%$ bolesnika je imalo smanjenu JGF kada se ona izračuna pomoću jednačina na bazi cistatina $\mathrm{C}$ dok su istovremeno upotrebom Schwartzove formule pokazivali normalnu JGF (178).

Kombinovano merenje koncentracije cistatina $\mathrm{C}$ u serumu i količine izlučivanja cistatina $\mathrm{C}$ mokraćom, korisno je za procenu početnog smanjenja jačine glomerulske filtracije i oštećenja proksimalnih tubula bubrega (179). Bolesnici sa klirensom endogenog kreatinina manjim od $30 \mathrm{ml} / \mathrm{min}$, statistički značajno izlučuju veću količinu cistatina $\mathrm{C}$ mokraćom $\mathrm{u}$ odnosu na ispitanike sa normalnim klirensom endogenog kreatinina. Povećanje frakcionog klirensa cistatina $\mathrm{C}$ odražava oštećenje funkcije epitelnih ćelija proksimalnih tubula (180).

Proteinurija nema statistički značajnog uticaja na koncentraciju cistatina $\mathrm{C} \mathrm{u}$ serumu kod bolesnika sa klirensom endogenog kreatinina $>80 \mathrm{ml} / \mathrm{min}$ (175).

Kod bolesnika sa hroničnim bolestima bubrega progresivno opada bubrežna funkcija. Merenje koncentracije kreatinina u serumu za procenu GFR treba uraditi najmanje jednom godišnje kod bolesnika sa hroničnim bolestima bubrega, a mnogo češće kod bolesnika sa: GFR $<60 \mathrm{ml} / \mathrm{min} / 1,73 \mathrm{~m}^{2}$, brzim opadanjem GFR $(\geq 4$ $\mathrm{ml} / \mathrm{min} / 1,73 \mathrm{~m}^{2} /$ godišnje. Stepen opadanja jačine glomerulske filtracije iznosi $\geq 4$ $\mathrm{ml} / \mathrm{min} / 1,73 \mathrm{~m}^{2} /$ godišnje (181).

U ovom radu pokazali smo da cistatin $\mathrm{C}$ ne zavisi od životne dobi bolesnika sa nefrotskim sindrom pri značajnoj proteinuriji. U svim životnim dobima koje su 
ispitivalne pri istom stepenu proteinurije cistatin $\mathrm{C}$ je ostao nepromenjen. $\mathrm{U}$ ranijim radovima smo pokazali da se pri klirensu kreatinina preko $80 \mathrm{ml} / \mathrm{min}$ cistatin $\mathrm{C}$ ne menja značajno, ali sa porastom proteinurije raste mu vrednost i kreće se oko gornje granice referentnog intervala (175). Uprkos masovnijem gubitku proteina i oštećenju tubulske funkcije kod bolesnika sa NS organizam teži da zadrži cistatin C, verovatno u cilju održavanja ravnoteže između proteaza koje se tokom bolesti aktiviraju i njihovih inhibitora pa cistatin $\mathrm{C}$ ima protektivnu ulogu. Kako kod bolesnika sa nefrotskim sindromom može doći do gubitka četvrtine JGF bez promene nivoa kreatinina u serumu i bez značajne promene $u$ klirensu kreatinina (177) to je neophodno $u$ daljim istraživanjima u svrhu upotrebe cistatina $\mathrm{C}$ za procenu JGF, ispitati nivo cistatina $\mathrm{C}$ kod bolesnika sa nefrotskim sindromom pri svakom porastu proteinurije za $1 \mathrm{~g} / 24$ sata.

\subsection{VREDNOSTI KREATININA, KLIRENSA KREATININA I CISTATINA C KOD BOLESNIKA SA DIABETES MELLITUS}

Prema podacima Svetske zdravstvene organizacije (WHO), prevalenca dijabetesa u svetu za sve starosne grupe 2000. godine iznosila je 2,8 \% dok se procenjuje da će 2030. godine biti 4,4 \% (182). Dijabetes je uzrok preko $30 \%$ slučajeva hronične terminalne bubrežne insuficijencije. Skup funkcionalnih i strukturnih oštećenja koja se javljaju tokom DM opisuju se pod nazivom dijabetesna nefropatija. Nefropatija nastaje kao posledica složenih interakcija između glomerula, tubula, intersticijuma i vaskularnih delova bubrega a čitav proces započinje izlučivanje glukoze u urin. Kako šećerna bolest (DM) vremenom dovodi do oštećenja bubrežne funkcije neophodno je pouzdanim testovima pratiti stanje bubrega kod osoba koje već imaju dijabetes ili kod kojih postoji rizik da ga dobiju, kao što su gojazni. Mogućnost da pouzdano procenimo rano oštećenje bubrega kod dijabetesne nefropatije još uvek nije na dovoljnom nivou koji iziskuje aktivan pristup u prevenciji oštećenja (183).

Da bi utvrdili da li kod Diabetes mellitus (DM) cistatin C može da bude pouzdani pokazatelj JGF kod 31 bolesnika, koji su bolovali od DM tip 2, prosečne starosti 57,29 godina (najmlađi bolesnik imao je 24 godine, a najstariji 79 godina), od kojih je bilo 15 muškaraca i 16 žena, određen je kreatinin, klirens kreatinina i cistatin C.

Poznato je da se DM tip 2 uglavnom javlja u starijem životnom dobu, što je bio slučaj i sa našim ispitivanim bolesnicima. Svi ispitanici su imali i druge različite bolesti bilo kao posledicu već prisutnog Diabetes mellitus ili nezavisno kao prateću bolest. Da 
bi utvrdili osetljivost posmatranih parametra za procenu JGF pri različitom stepenu smanjenja renalne funkcije, bolesnici su podeljeni $\mathrm{u}$ tri grupe $\mathrm{u}$ odnosu na klirens kreatinina (Slika 54). U prvoj grupi bolesnika sa prosečnim klirensom ispod $40 \mathrm{ml} / \mathrm{min}$, bilo je 15 bolesnika, u drugoj grupi sa prosečnim klirensom kreatinina od $40 \mathrm{ml} / \mathrm{min}$ do $59,9 \mathrm{ml} / \mathrm{min}$ bilo je 8 bolesnika, dok je u trećoj grupi bolesnika sa prosečnim klirensom kreatinina preko $60 \mathrm{ml} / \mathrm{min}$ bilo 8 ispitanika.

Grupu sa klirensom kreatinina većim od $60 \mathrm{ml} / \mathrm{min}$ činili su najmlađi bolesnici, prosečne starosti 48 godina dok su u II grupi bili bolesnici prosečne starosti 62,63 godina a u I grupi su bili bolesnici prosečne starosti 60,33 godina (Tabela 56). Nije bilo statistički značajna razlika u životnoj dobi među grupama $(\mathrm{F}=2,43 \mathrm{p}=0,106)$ (Slika 55).

Najvišu prosečnu vrednost kreatinina u serumu 435,27 $\pm 244,00 \mu \mathrm{mol} / 1$, imali su bolesnici koji pripadaju I grupi tj. sa najnižim klirensom kreatinina, dok su bolesnici iz II grupe imali prosečni kreatinin u serumu 168,75 $\pm 40,33 \mu \mathrm{mol} / \mathrm{l}$ a u III grupi prosečna vrednost kreatinina je bila 75,25 $\pm 11,88 \mu \mathrm{mol} / \mathrm{l}$ i ujedno su se vrednosti visoko statistički značajno razlikovale u odnosu na grupu koja je formirana prema klirensu kreatinina (Tabela 57). Bolesnici sa nižim klirensom kreatinina imaju statistički značajno više vrednosti kreatinina u serumu $(\mathrm{F}=13,13 \mathrm{p}<0,0001)$ (Slika 56).

U ispitivanju koje je obuhvatilo 335 bolesnika sa DM tip 2 bolesnici su u odnosu na albuminuriju razvrstani u tri grupe. Kao i u našem ispitivanju dobijeno je da se vrednosti kreatinina u serumu statistički značajno razlikuju među grupama od 79,56 $\mu \mathrm{mol} / 1$ kod normoalbuminuričnih bolesnika koji su imali jačinu glomerulske filtracije procenjenu MDRD jednačinom 84,6 \pm 23,3 ml/min, preko 97,24 $\mu \mathrm{mol} / 1 \mathrm{kod}$ bolesnika sa mikroalbuminurijom i JGF od 76,0 $\pm 27,8 \mathrm{ml} / \mathrm{min}$ do $203,32 \mu \mathrm{mol} / 1 \mathrm{kod}$ bolesnika sa makroalbuminurijom i JGF 44,9 $\pm 26,6 \mathrm{ml} / \mathrm{min}$. JGF se takođe statistički značajno razlikovala među grupama (184). Uobičajeno bolesnike sa DM prati pojava mikroalbuminurije, smanjenje klirensa kreatinina i porast serumskog kreatinina. Međutim pokazalo se da $20 \%$ do $30 \%$ bolesnika sa DM tip 2 i pratećom bubrežnom insuficijencijom ima normoalbuminuriju. Iz ovog razloga se smatra da samo praćenje stepena albuminurije i nivoa serumskog keatinina, zbog njegove zavisnosti od životne dobi, mišićne mase, rase i pola kao i načina ishrane, nije dovoljno da opiše sve promene u funkciji bubrega koje kod ovih bolesnika nastaju (185).

Kao što smo i očekivali, u našem ispitivanju najvišu prosečnu vrednost klirensa kreatinina $141,49 \pm 26,79 \mathrm{ml} / \mathrm{min}$ imali su bolesnici koji pripadaju III grupi tj. sa klirensom preko $60 \mathrm{ml} / \mathrm{min}$, dok su bolesnici iz II grupe imali prosečni klirens 
kreatinina 49,65 $\pm 8,70 \mathrm{ml} / \mathrm{min}$ a u I grupi prosečni klirens kreatinina je bio $17,88 \pm$ $11,88 \mathrm{ml} / \mathrm{min}$ uz postojanje statistički značajne razlike u odnosu na grupu bolesnika sa DM (F=149,64 p<0,0001) (Tabela 58, Slika 57).

Bolesnici sa DM čiji je klirens kreatinina bio niži od $40 \mathrm{ml} / \mathrm{min}$ imali su najvišu prosečnu vrednost cistatina $\mathrm{C}$ u serumu 3,18 $\pm 1,03 \mathrm{mg} / \mathrm{l}$, dok su bolesnici iz II grupe imali prosečni nivo cistatina $\mathrm{C}$ u serumu 2,22 $\pm 0,34 \mathrm{mg} / \mathrm{l}$, dok su bolesnici sa klirensom kreatinina preko $60 \mathrm{ml} / \mathrm{min}$ imali najniže vrednosti cistatina C $0,93 \pm 0,23 \mathrm{mg} / 1$ (Tabela 59). Vrednosti cistatina $\mathrm{C}$ su se visoko statistički značajno razlikovale među grupama formiranim prema klirensu kreatinina $(\mathrm{F}=23,377 \mathrm{p}<0,0001)$ (Slika 58). Ovi rezultati su saglasni sa rezultatima drugih istraživača koji su utvrdili da su normoalbuminurični bolesnici sa DM imali statistički značajno viši cistatin C pri JGF $\leq 60 \mathrm{ml} / \mathrm{min} / 1,73 \mathrm{~m}^{2}$ od bolesnika čija je JGF bila $>60 \mathrm{ml} / \mathrm{min} / 1,73 \mathrm{~m}^{2}$ (184).

Najvišu prosečnu recipročnu vrednost cistatina $\mathrm{C}$ od 1,14 $\pm 0,27$ imali su bolesnici koji pripadaju III grupi tj. sa najvišim klirensom kreatinina (Tabela 60).

Bolesnici iz II grupe su imali prosečnu recipročnu vrednost cistatina $\mathrm{C} 0,46 \pm 0,07 \mathrm{a}$ najnižu prosečnu recipročnu vrednost cistatina $\mathrm{C}, 0,34 \pm 0,27$ imali su bolesnici sa najnižim klirensom kreatinina tj. iz I grupe. Statistički značajno različite vrednosti 1/cistatin $\mathrm{C}$ su bile među grupama koje su formirane prema klirensu kreatinina ( $\mathrm{F}=65,14$ $\mathrm{p}<0,0001)($ Slika 59).

Ispitivana grupa je bila nehomogena što je uslovilo veliki koeficijent varijacije među vrednostima posmatranih parametara pa su primenjeni dodatni statistički testovi u cilju definisanja razlika među grupama. Primenom Kruskal Wallis testa dokazana je visoko statistički značajna razlika vrednosti klirensa kreatinina, kreatinina, cistatina $\mathrm{C}$ i recipročne vrednosti cistatina $\mathrm{C}$ među ispitivanim grupama $(\mathrm{p}<0,0001)$.

Primenom Spearmanovog korelacionog testa utvrdjeno je da kod 31 bolesnika sa DM postoji visoko statistički značajna obrnuta korelacija cistatina $\mathrm{C}$ sa klirensom kreatinina, tj. višim vrednostima cistatina $\mathrm{C}$ odgovaraju niže vrednosti klirensa kreatinina $(\mathrm{R}=-0,875 \mathrm{p}<0,0001)($ Tabela 61).

Takođe je dokazana direktna visoko statistički značajna korelacija cistatina $\mathrm{C}$ sa kreatininom i obrnuta statistički značajna korelacija cistatina $C$ sa $1 /$ cistatin $C$. Ispitivanje koje je obuhvatilo 30 Pima Indijanaca sa DM tip 2 i JGF $>120 \mathrm{ml} / \mathrm{min} / 1,73$ $\mathrm{m}^{2}$, pokazalo je serijskim merenjem jednom godišnje tokom tri godine, da JGF određivana primenom odnosa 100/cistatin C bolje nego odnos 100/kreatinin odražava promene koje se u ovom periodu dešavaju u JGF. Takođe odnos 100/cistatin C bolje 
korelira sa direktno merenim klirensom iotalamata od odnosa 100/kreatinin. Takođe ovi autori smatraju da serijsko određivanje cistatina $\mathrm{C}$ omogućava dugoročnu prognozu trenda bubrežnih bolesti kod bolesnika DM (186).

Ispitivanje međusobnih odnosa posmatranih parametara unutar svake grupe pojedinačno pokazalo je da u I grupi tj. sa klirensom kreatinina $<40 \mathrm{ml} / \mathrm{min}$ postoji statistički značajna obrnuta korelacija cistatina $C$ sa klirensom kreatinina $(R=-0,697$ $\mathrm{p}<0,005)$.

Takođe postoji i direktna statistički značajna korelacija cistatina $\mathrm{C}$ sa kreatininom, i obrnuta statistički značajna korelacija 1/cistatina C sa kreatininom. Klirens kreatinina je u obrnutoj statistički značajnoj korelaciji sa kreatininom u serumu $(\mathrm{p}<0,001)($ Tabela 62)

U II grupi, koju čine bolesnici sa DM čija je vrednost klirensa kreatinina između $60 \mathrm{ml} / \mathrm{min}$ i $40 \mathrm{ml} / \mathrm{min}$, takođe je utvrđena obrnuta statistički značajna korelacija cistatina $\mathrm{C}$ sa klirensom kreatinina, tj. više vrednosti cistatina $\mathrm{C}$ odgovaraju nižim vrednostima klirensa kreatinina, $(\mathrm{R}=-0,707 \mathrm{p}<0,05)($ Tabela 63$)$.

U II grupi je utvrđena direktna statistički značajna korelacija cistatina $\mathrm{C}$ sa kreatininom $(\mathrm{R}=0,8342 \mathrm{p}<0,01)$ i obrnuta statistički značajna korelacija cistatina $\mathrm{C}$ sa $1 /$ cistatin $C(R=-0,994 p<0,0001)$. Takođe kreatinin statistički značajno korelira sa klirensom kreatinina u ovoj grupi $(\mathrm{R}=-0,967 \mathrm{p}<0,01)$.

U III grupi koju su činili bolesnici sa klirensom kreatinina $>60 \mathrm{ml} / \mathrm{min}$ nije dokazana statistički značajna korelacija cistatina $\mathrm{C}$ sa klirensom kreatinina, premda više vrednosti cistatina $\mathrm{C}$ koreliraju sa nižim vrednostima klirensa kreatinina, ali bez statističke značajnosti $(\mathrm{R}=0,310 \mathrm{p}=\mathrm{ns})$ (Tabela 64$)$. Takođe nije dokazana statistički značajna korelacija između cistatina $\mathrm{C}$ i vrednosti kreatinina u serumu iako je sa porastom nivoa kreatinina rastao i nivo cistatina $C(R=-0,578 \mathrm{p}=\mathrm{ns})$. Naši rezultati su $\mathrm{u}$ skladu sa podacima iz literature. Ispitivanje koje je obuhvatilo 40 bolesnika sa DM tip 2 koji su podeljeni u 4 grupe u zavisnosti od albuminurije je pokazalo da cistatin $\mathrm{C}$ dobro korelira sa klirensom kreatinina i kreatininom u serumu kod svih grupa bolesnika osim kod bolesnika sa DM bez albuminurije (187).

Rane promene na glomerulima kod bolesnika sa DM započinju povećanjem glomerulske filtracije, koja može da se poveća i za 40 \%. Uzroci hiperfiltracije u prvim godinama dijabetesne nefropatije nisu sasvim poznati i naročito su izraženi kod bolesnika sa DM tip 1. Na povećanje glomerulske filtracije utiču i natriuretski peptidi. Usled oštećenja bazalne membrane glomerula dolazi do većeg prolaska proteina kroz 
glomerul a naročito onih sa negativnim naelektrisanjem male molekulske mase. Takođe vezivanje glukoze za proteine povećava njihov transport kroz glomerulsku membranu usled čega dolazi do opterećenja tubula i poremećaja njihove funkcije jer nisu u stanju da reapsorbuju sve proteine, te se oni pojavljuju u urinu (188). Usled povećanog prisustva glukoze dodatno dolazi do oštećenja epitelnih ćelija tubula, pa se smatra da je nivo cistatina $\mathrm{C}$ u serumu i urinu u vezi sa subkliničkim tubulskim oštećenjem te može da bude raniji merljivi renalni marker pre pojave albuminurije (184).

Mnogi slučajevi krajnjeg stadijuma bubrežnih bolesti (ESRD) su uzrokovani dijabetesom $\mathrm{i}$ taj broj neprestano raste posebno $\mathrm{u}$ poslednjih nekoliko dekada. Dijabetična nefropatija dovodi do kardiovaskularnih bolesti i prevremene smrti i pojedinačno je vrlo čest uzrok krajnjeg satdijuma bubrežnih bolesti (ESRD) u razvijenim zemljama. Takođe je važno da se idealan marker dijabetesne nefropatije ne ograničava na određeni stadijum bolesti bubrega ili konkretnu starosnu grupu, jer dijabetična nefropatija napreduje tokom čitavog života dijabetičara i ima čitav spektar manifestacija od blagog oštećenja JGF do krajnjeg stadijuma bubrežne bolesti kada je neophodna dijaliza. Bez obzira što cistatin $\mathrm{C}$ nije dovoljno osetljiv pokazatelj JGF u početnim stadijumima dijabetesne nefropatije, verujemo da cistatin $\mathrm{C}$ može pouzdano da reprezentuje stanje bubrega kod bolesnika sa šećernom bolešću čiji je klirens kreatinina manji od $60 \mathrm{ml} / \mathrm{min}$. 


\section{ZAKLJUČCI}

Na osnovu izloženih ispitivanja može se zaključiti da:

\section{1. poređenje vrednosti klirensa ${ }^{99 m}$ Tc-DTPA i cistatina $C$ pokazuje da}

a. kod osoba sa različitim bubrežnim bolestima postoji visoko statistički značajna korelacija između klirensa ${ }^{99 \mathrm{~m}}$ Tc-DTPA i cistatina $\mathrm{C}$,

b. kod bolesnika sa različitim bubrežnim bolestima postoji visoko statistički značajna korelacija cistatina $\mathrm{C}$ sa kreatininom u serumu,

c. na nivo cistatina $\mathrm{C}$, kao ni na klirens ${ }^{99 \mathrm{~m}}$ Tc-DTPA kod bolesnika sa različitim bubrežnim bolestima ne utiče pol bolesnika, za razliku od vrednosti kreatinina, koje su više kod muškaraca,

d. kod muškaraca i kod žena sa različitim bubrežnim bolestima postoji statistički značajna korelacija između klirensa ${ }^{99 \mathrm{~m}}$ Tc-DTPA i cistatina $\mathrm{C}$,

e. recipročna vrednost cistatina $\mathrm{C}$ jače (visoko statistički značajno) korelira sa klirensom ${ }^{99 \mathrm{~m}}$ Tc-DTPA od korelacije cistatina C i klirensa ${ }^{99 \mathrm{~m}}$ Tc-DTPA kod osoba ženskog pola,

f. na nivo cistatina $\mathrm{C}$ kod bolesnika sa različitim bubrežnim bolestima ne utiče životna dob,

g. cistatin $\mathrm{C}$ je dobar pokazatelj jačine glomerulske filtracije kod osoba sa različitim bubrežnim bolestima jer dobro korelira sa klirensom ${ }^{99 \mathrm{~m}} \mathrm{Tc}$ DTPA,

\section{2. u nekomplikovanoj trudnoći}

a. se klirens kreatinina ne menja tokom čitavog gestacionog perioda,

b. u drugom i trećem trimestru cistatin $\mathrm{C}$ ima trend rasta,

c. ne postoji korelacija klirensa kreatinina $\mathrm{i}$ gestacionog perioda, postoji statistički značajna korelacija cistatina $\mathrm{C}$ i gestacionog perioda, a visoko statistički značajna korelacija 1/cistatin $\mathrm{C}$ i gestacionog perioda,

d. postoji visoko statistički značajna korelacija cistatina $\mathrm{C}$ i $1 /$ cistatin $\mathrm{C}$ sa klirensom kreatinina u prvom trimestru trudnoće, 
e. ne postoje korelacije cistatina $\mathrm{C}$ i $1 /$ cistatin $\mathrm{C}$ sa klirensom kreatinina $\mathrm{u}$ drugom i trećem trimestru trudnoće,

f. u posmatranim starosnim grupama nivo cistatin $C$ ima trend porasta $u$ svim gestacionim periodima, koji je statistički značajan u trećem trimestru u odnosu na prvi i drugi trimestar,

g. cistatin C nije dobar pokazatelj jačine glomerulske filtracije kod trudnica u drugom i trećem trimestru jer ne postoji korelacija sa klirensom kreatinina,

\section{3. kod trudnica sa trudnoćom izazvanom hipertenzijom}

a. prosečne vrednosti cistatina $\mathrm{C}$ su statistički značajno više kod trudnica sa trudnoćom izazvanom hipertenzijom $u$ odnosu na zdrave trudnice iste gestacione dobi,

b. ne postoji statistički značajna korelacija cistatina $\mathrm{C}$ i 1/ cistatin $\mathrm{C}$ sa klirensom kreatinina kod trudnica sa PIH,

c. nivo cistatina $\mathrm{C}$ statistički značajno raste sa starošću trudnica sa PIH, dok klirens kreatinina ostaje nepromenjen,

d. trudnice sa PIH preko 35 godina života imaju statistički značajno najviše vrednosti cistatina $C$,

e. cistatin C nije dobar pokazatelj jačine glomerulske filtracije kod trudnica sa PIH, jer ne postoji korelacija sa klirensom kreatinina,

f. da rast cistatina $C$ tokom normalne trudnoće ima protektivnu ulogu jer sprečava prekomerni porast raznih proteaza koje bi mogle negativno da utiču na razvoj ploda i normalan tok trudnoće,

g. da rast cistatina $C$ tokom trudnoće može da predstavlja meru transformacije normalne trudnoće u komlikovanu do preeklampsije,

\section{4. kod obolelih od Balkanske endemske nefropatije}

a. cistatin $\mathrm{C}$ statistički značajno raste sa padom klirensa kreatinina, 
b. cistatin $\mathrm{C}$ statistički značajno raste sa rastom koncentracija kreatinina $\mathrm{u}$ serumu,

c. nije utvrdjena statistički značajna razlika u vrednostima klirensa kreatinina i cistatina $\mathrm{C}$ u odnosu na starost,

d. cistatin C je osetljiv pokazatelj jačine glomerulske filtracije kod bolesnika sa Balkanskom endemskom nefropatijom,

\section{2. kod obolelih sa nefrotskim sindromom}

a. cistatin $\mathrm{C}$ je statistički značajno viši kod bolesnika sa nefrotskom proteinurijom u odnosu na osobe bez proteinurije,

b. klirens kreatinina je statistički značajno niži kod bolesnika sa nefrotskom proteinurijom u odnosu na osobe bez proteinurije,

c. kod bolesnika sa nefrotskim sindromom nivo cistatina $\mathrm{C}$ i kreatinina ne zavisi od životne dobi bolesnika,

d. klirens kreatinina se statistički značajno razlikovao kod bolesnika sa nefrotskom proteinurijom u odnosu na životnu dob bolesnika,

e. cistatin $\mathrm{C}$ je osetljiv pokazatelj jačine glomerulske filtracije jer na njegov nivo ne utiče starosna dob,

\section{5. kod obolelih od Diabetes Mellitus tip 2}

a. cistatin $\mathrm{C}$ direktno statistički značajno korelira sa kreatininemijom u odmaklim stadijumima bubrežne slabosti kad je klirens kreatinina manji od $60 \mathrm{ml} / \mathrm{min}$

b. cistatin $\mathrm{C}$ obrnuto statistički značajno korelira sa klirensom kreatinina kod bolesnika koji imaju odmaklu bubrežnu slabost i klirens kreatinina manji od $60 \mathrm{ml} / \mathrm{min}$, a ne korelira sa onima koji imaju više vrednosti klirensa kreatinina,

c. cistatin $\mathrm{C}$ nije dovoljno osetljiv pokazatelj jačine glomerulske filtracije u početnim stadijumima dijabetesne nefropatije. 


\section{LITERATURA}

1. Delaney MP, Price CP, Newman DJ, Lamb E. Kidney disease. In: Burtis CA, Ashwood ER, Bruns DE, editors. Tietz textbook of clinical chemistry and molecular diagnosis. 4th ed. St Louis: Elsevier Saunders; 2006; pp. 1671-46.

2. Stefanović S i saradnici: Specijalna klinička fiziologija, III izdanje ("Medicinska knjiga" Beograd-Zagreb, 1980.).

3. Anđelković Z, Somer Lj, Perović M, Avramović V, Milenkova Lj, Kostovska N, Petrović A. Histološka građa organa, I izdanje ("Bonafides" Niš, 2001.).

4. Trpinac D: Histologija za studente farmacije, IV izdanje ("Kuća štampe" Beograd, 2000.).

5. Guyton A, Hall J. Medical phisiology, $11^{\text {th }}$ edition, W.B. Saunders, Philadelphia, 2006.

6. Majkić-Singh N. Funkcija bubrega i neproteinska azotna jedinjenja. Medicinska biohemija, drugo izdanje, DMBS, 2006.

7. Renal Data System. 2005 Annual data report: atlas of end-stage renal disease in the United States. Bethesda, Md.: National Institute of Diabetes and Digestive and Kidney Diseases, 2005.

8. Coresh J, Byrd-Holt D, Astor B. C et al. Chronic kidney disease awareness, prevalence, and trends among U.S. adults, 1999 to 2000. J Am Soc Nephrol 2005; 16: 180-8.

9. Chobanian AV, Bakris GL, Black HR et al. The Seventh Report of the Joint National Committee on Prevention, Detection, Evaluation, and Treatment of High Blood Pressure: the JNC 7 report. JAMA 2003; 289(19): 2560-72.

10. Sarnak MJ, Levey AS, Schoolwerth AC, et al. Kidney disease as a risk factor for development of cardiovascular disease: a statement from the American Heart Association Councils on Kidney in Cardiovascular Disease, High Blood Pressure Research, Clinical Cardiology, and Epidemiology and Prevention. Hypertension 2003; 42: 1050-65. 
11. Brosius FC III, Hostetter TH, Kelepouris E, Mitsnefes MM, Moe SM, Moore MA, Pennathur S, Smith GL, Wilson PW. Detection of chronic kidney disease in patients with or at increased risk of cardiovascular disease: a science advisory from the American Heart Association Kidney and Cardiovascular Disease Council; the Councils on High Blood Pressure Research, Cardiovascular Disease in the Young, and Epidemiology and Prevention; and the Quality of Care and Outcomes Research Interdisciplinary Working Group: developed in collaboration with the National Kidney Foundation. Circulation. 2006; 114: 1083-7.

12. Levey AS, Eckardt KU, Tsukamoto $\mathrm{Y}$ et al. Definition and classification of chronic kidney disease: a position statement from Kidney Disease: Improving Global Outcomes (KDIGO). Kidney Int 2005; 67: 2089-100.

13. National Kidney Foundation. K/DOQI clinical practice guidelines for chronic kidney disease: evaluation, classification, and stratification. Am J Kidney Dis 2002; 39:Suppl 1:S1-S266.

14. Lindeman RD. Hypertension and kidney protection in the elderly: what is the evidence in 2007? Int Urol Nephrol. 2007; 39(2): 669-78.

15. Marieb Elaine N. Human Anatomy \& Physiology, Sixth Edition, Pearson Education, 2004; Inc., USA 1000-22.

16. Maynard SE, Min JY, Merchan J, Lim KH, Li J, Mondal S, Libermann TA, Morgan JP, Sellke FW, Stillman IE, Epstein FH, Sukhatme VP, Karumanchi SA. Excess placental soluble fms-like tyrosine kinase 1 (sFlt1) may contribute to endothelial dysfunction, hypertension, and proteinuria in preeclampsia. $\mathrm{J}$ Clin Invest 2003; 111: 649-58.

17. Lu F, Longo M, Tamayo E, Maner W, Al-Hendy A, Anderson GD, Hankins GDV, Saade GR. The effect of over-expression of sFlt-1 on blood pressure and the occurrence of other manifestations of preeclampsia in unrestrained conscious pregnant mice. Am J Obstet Gynecol 2007; 196, 396.

18. Jeyabalan A, Conrad KP. Renal function during normal pregnancy and preeclampsia. Front Biosci. 2007; 12(1): 2425-37.

19. Sharon E, Thadhani M and R. Pregnancy and the Kidney. JASN 2009; 20(1): $14-22$.

20. Brochner-Mortensen J, Giese J, Rossing N. Renal inulin clearance versus total plasma clearance of 51Cr-EDTA. Scand J Clin Lab Invest 1969; 23: 301-5. 
21. Aurell M. Accurate and feasible measurements of GFR - is the iohexol clearance the answer? Nephrol Dial Transplant 1994; 9: 1222-4.

22. Stevens LA, Coresh J, Greene T, Levey AS. Assessing kidney function: Measured and estimated glomerular filtration rate. New England Journal of Medicine, 2006; 354(23): 2473-83.

23. Itoh K. Comparison of methods for determination of glomerular filtration rate: Tc-99m-DTPA renography, predicted creatinine clearance method and plasma sample method. Ann Nucl Med 2003; 17(7): 561-5.

24. Fotopoulos A, Bokharhli JA, Tsiouris S, Katsaraki A, Papadopoulos A, Tsironi $\mathrm{M}$ et al. Comparison of six radionuclidic and nonradionuclidic methods for the assessment of glomerular filtration rate in patients with chronic renal failure. Hell J Nucl Med 2006; 9(2): 133-40.

25. Effersoe H, Rosenkilde P, Groth S. Measurement of renal function with iohexol. A comparison of iohexol, 99mTc-DTPA, and 51Cr-EDTA clearance. Invest Radiol 1990; 25: 778-82.

26. John S, Peter W, James A et al. Methods for measuring GFR with 99mTcDTPA: an analysis of several common methods. J Nucl Med 1990; 31: 121119.

27. Natale G, Pirtro A, Massimo $\mathrm{C}$ et al. Measurement of glomerular Filtration Rate by the 99mTc-DTPA Renal dynamic imaging Is Less Precise than Measured and Predicted Creatinine learance. Nephron 1999; 81: 136-40.

28. Rehling M, Moller ML, Thamdrup B, Lund JO, Trap-Jensen J. Simultaneous measurement of renal clearance and plasma clearance of 99mTc-labelled diethylenetriaminepenta-acetate, 51Cr-labelled ethylenediaminetetra-acetate and inulin in man.Clin Sci 1984; 66: 613-19.

29. Cousins C, Gunasekera RD, Mubashar M, Mohammadtaghi S, Strong R, Myers MJ. Comparative kinetics of microvascular inulin and 99m Tc-labelled diethylenetriaminepenta-acetic acid exchange. Clin Sci 1997; 93: 471-77.

30. Stevens LA, Levey AS. Measurement of kidney function. Med Clin North Am 2005; 89: 457-73.

31. Bokenkamp A, Domanetzki M, Zinck R, Schumann G, Byrd D et al.Cystatin C - a new marker of glomerular filtration rate in children independent of age and height. Pediatrics 1998; 101: 875-81. 
32. Perrone RD, Madias NE, Levey AS. Serum creatinine as an index of renal function: new insights into old concepts. Clin Chem 1992; 38: 1933-53.

33. Levey AS. Measurement of renal function in chronic renal disease. Kidney Int 1990; 38: 167-84.

34. Marques PJL, Rocco R, Victor MH, de Novaes BC, de Carvalho ALB, da Rosa Santos O. Clinical use of estimating glomerular filtration rate equ-ations during pregnancy . Health 2011;3(1): 32-6.

35. Fischer MJ. Chronic kidney disease and pregnancy: Maternal and fetal outcomes. Adv Chronic Kidney Dis 2007; 14: 132-45.

36. Smith MC, Moran P, Ward MK, Davison JM. Assessment of glomerular filtration rate during pregnancy using the MDRD formula. BJOG 2008; 115 : 109-12.

37. Alper AB, Yi Y, Webber LS, Pridjian G, Mumuney AA, Saade G, Morgan J, Nuwayhid B, Belfort M, Puschett J. Estimation of glomerular filtration rate in preeclamptic patients. Am J Perinatol 2007; 24: 569-74.

38. Rule AD, Larson TS, Bergstralh EJ, Slezak JM, Jacobsen SJ, Cosio FG. Using serum creatinine to estimate glomerular filtration rate: Accuracy in good health and in chronic kidney disease. Ann Intern Med 2004; 141: 929-37.

39. Myers GL, Miller WG, Coresh J, Fleming J, Greenberg N, Greene T et al. Recommendarions for improving serum creatinine measurement: a report from the laboratory working group of the National Kidney Disease Educarion program. Clin Chem 2006; 52: 5-18.

40. Carobene A, Ferrero C, Ceriotti F, Modenese A, Besozzi M, De Giorgi E et al. Creatinine measurement proficiency testing: assignment of matrix-adjusted ID GSMS target values. Clin Chem 1997; 43: 1342-7.

41. Panteghini M, Myers GL, Miller WG, Greenberg N. The importance of metrological traceability on the validity of creatinine measurement as an index of renal function. Clin Chem Lab Med 2006; 44: 1287-92.

42. Thomas L, Huber AR. Renal function - estimation of glomerular filtration rate. Clin Chem Lab Med 2006; 44(11): 1295-302.

43. White CA, Knoll GA, Poggio ED. Measuring vs estimating glomerular filtration rate in kidney transplantation. Transplant Rev (Orlando) 2010; 24(1): $18-27$. 
44. Koetje MJLP, Spaan JJ, Kooman PJ, Spaanderman EAM, Peeters LL. Pregnancy Reduces the Accuracy of the Estimated Glomerular Filtration Rate Based on Cockroft-Gault and MDRD Formulas. Reproductive Sciences 2011; 18(5): 456-62.

45. Skali H, Uno H, Levey AS, Inker LA, Pfeffer MA, Solomon SD. Prognostic assessment of estimated glomerular filtration rate by the new Chronic Kidney Disease Epidemiology Collaboration equation in comparison with the Modification of Diet in Renal Disease Study equation. American Heart Journal 2011; 162: 548-54.

46. Grubb A, Simonsen O, Sturfelt G. Serum concentration of cystatin C, factor D and beta 2-microglobulin as a measure of glomerular filtration rate. Acta Med Scand $1985 ; 218: 499-503$.

47. Simonsen $\mathrm{O}$, Grubb A, Thysell $\mathrm{H}$. The blood serum concentration of cystatin $\mathrm{C}$ (gamma-trace) as a measure of the glomerular filtration rate. Scand J Clin Lab Invest 1985; 45: 97-101.

48. Tenstad O, Roald AB, Grubb A, Aukland K. Renal handling of radiolabelled human cystatin C in the rat. Scand J Clin Lab Invest 1996; 56: 409-14.

49. Grubb A, Löfberg H. "Human gamma-trace, a basic microprotein: amino acid sequence and presence in the adenohypophysis". Proc Natl Acad Sci USA1982; 79(9): 3024-7.

50. Janowski R, Kozak M, Jankowska $\mathrm{E}$ et al. "Human cystatin C, an amyloidogenic protein, dimerizes through three-dimensional domain swapping". Nat Struct Biol 2001; 8(4): 316-20.

51. Grubb A. Diagnostic value of analysis of cystatin $\mathrm{C}$ and protein $\mathrm{HC}$ in biological fluids. Clin Nephrol 1992; 38(Suppl 1): S20-7.

52. Abrahamson M, Barrett AJ, Salvesen G, Grubb A. Isolation of six cysteine proteinase inhibitors from human urine. Their physicochemical and enzyme kinetic properties and concentrations in biological fluids. J Biol Chem. 1986; 261: 11282-9.

53. Mussap M, Plebani M. Biochemistry and clinical role of human cystatin C. Crit i Rev Clin Lab Sci 2004; 41: 467-50.

54. Eikel I and Abrahamson M. Folding-related dimerization of human cystatin C. J Biol Chem 1996; 271(3): 1314. 
55. Mi W, Pawlik M, Sastre M et al. "Cystatin C inhibits amyloid-beta deposition in Alzheimer's disease mouse models". Nat Genet 2007; 39(12): 1440-2.

56. Sun B, Zhou Y, Halabisky B, Lo I, Cho HS, Mueller-Steiner S, Wang X, Grubb A and Gan L. Cystatin C-Cathepsin B Axis Regulates Amyloid Beta Levels and Associated Neuronal Deficits in an Animal Model of Alzheimer's Disease Neuron 2008; 60(2): 247-57.

57. Levy E, Lopez-Otin C, Ghiso J, Geltner D, Frangione B. "Stroke in Icelandic patients with hereditary amyloid angiopathy is related to a mutation in the cystatin C gene, an inhibitor of cysteine proteases". J Exp Med 1989; 169(5): 1771-8.

58. Levy E, Jaskolski M, Grubb A. "The role of cystatin C in cerebral amyloid angiopathy and stroke: cell biology and animal models". Brain Pathol 2006; 16(1): 60-70.

59. Coresh J, Byrd-Holt D, Astor BC, Briggs JP, et al. Chronic kidney disease awareness, prevalence, and trends among U.S. adults, 1999 to $2000 \mathrm{~J}$ Am Soc Nephrol 2005; 16: 180-8.

60. Spanaus K-S, Kollerits B, Ritz E, Hersberger M, et al. Serum creatinine, cystatin $\mathrm{C}$, and $\beta$-Trace protein in diagnostic staging and predicting progression of primary nondiabetic chronic kidney disease. Clin Chem 2010; 56: 740-9.

61. Mehta RL, Mcdonald B \& Gabbai FB et al. A randomized clinical trial of continuous versus intermittent dialysis for acute renal failure. Kidney Int 2001; 60: $1154-63$.

62. Morgera S, Kraft AK\&Siebert $\mathrm{G}$ et al. Long-term outcomes in acute renal failure patients treated with continuous renal replacement therapies. Am J Kidney Dis 2002; 40: 275-9.

63. Chertow GM, Levy EM\&Hammermeister KE et al. Independent association between acute renal failure and mortality following cardiac surgery. Am J Med 1998; 104: 343-8.

64. LianoF\&Pascual J. Epidemiology of acute renal failure: A prospective, multicenter, community-based study. Kidney Int 1996; 50: 811-8.

65. Metnitz PGH, Krenn CG\&Steltzer $\mathrm{H}$ et al. Effect of acute renal failure requiring renal replacement therapy on outcome in critically ill patients. Crit Care Med 2002; 30: 2051-8. 
66. Clermont G, Acker CG \& Angus DC et al. Renal failure in the ICU: Comparison of the impact of acute renal failure and end-stage renal disease on ICU outcomes. Kidney Int 2002; 62: 986-96.

67. Bellomo R, Kellum JA \& Ronco C. Defining acute renal: Physiological principles. Intensive Care Med 2004; 30: 33-7.

68. Herget-Rosenthal S, Marggraf G, Hüsing J,Göring F, Pietruck F, Janssen O, Philipp $\mathrm{T}$ and Kribben A. Early detection of acute renal failure by serum cystatin C. Kidney International 2004; 66: 1115-22.

69. Soto K, Coelho S, Rodrigues B, Martins H, Frade F, Lopes S, Cunha L, Papoila AL, Devarajan P. Cystatin C as a marker of acute kidney injury in the emergency department. Clin J Am Soc Nephrol 2010; 5(10): 1745-54.

70. Lassus JP, Harjola VP, Peuhkurinen K, Sund R, Mebazaa A, Siirilä-Waris K, Miettinen K, Punnonen K R, Melin J, Pulkki K, Nieminen M S. Cystatin C, NT-proBNP, and inflammatory markers in acute heart failure: insights into the cardiorenal syndrome. Biomarkers 2011; 16(4): 302-10.

71. Stickle D, Cole B, Hock K, Hruska KA, Scott MG. Correlation of plasma concentrations of cystatin $\mathrm{C}$ and creatinine to inulin clearance in a pediatric population. Clin Chem 1998; 44: 1334-8.

72. Bökenkamp A, Dieterich C, Dressler F, Mühlhaus K, Gembruch U, Bald R et al. Fetal serum concentrations of cystatin $\mathrm{C}$ and $\beta_{2}$-microglobulin as predictors of postnatal kidney function. American Journal of Obstetrics \& Gynecology 2001; 185(2): 468-75.

73. Bahar A, Yilmaz Y, Unver S, Gocmen I, Karademir F. Reference values of umbilical cord and third-day cystatin $\mathrm{C}$ levels for determining glomerular filtration rates in newborns. J Int Med Res 2003; 31: 231-5.

74. Filler G, Priem F, Lepage N, Sinha P, Vollmer I, Clark H, Keely E, Matzinger M, Akbari A, Althaus H, Jung K. Beta-trace protein, cystatin C, beta $2^{-}$ microglobulin, and creatinine compared for detecting impaired glomerular filtration rates in children. Clin Chem 2002; 48: 729-36.

75. Willems HL, Hilbrands LB, van de Calseyde JF, Monnens LA, Swinkels DW. Is serum cystatin $\mathrm{C}$ the marker of choice to predict glomerular filtration rate in paediatric patients? Ann Clin Biochem 2003; 40: 60-4. 
76. Martini S, Prevot A, Mosig D, Werner D, van Melle G, Guignard JP. Glomerular filtration rate: measure creatin-ine and height rather than cystatin C. Acta Paediatr 2003; 92: 1052-7.

77. Zaffanello M, Franchini $M$ and Fanos V. Is Serum Cystatin-C a Suitable Marker of Renal Function in Children? Annals of Clinical \& Laboratory Science 2007; 37: 233-40.

78. Sharma AP, Yasin A, Garg AX, Filler G. Diagnostic Accuracy of Cystatin CBased eGFR Equations at Different GFR Levels in Children CJASN 2011; 6: 1599-608.

79. Blufpand HN, Tromp J, Abbink FCH, Stoffel-Wagner B, Bouman AA, Schouten-van Meeteren AYN, van Wijk JAE, Kaspers GJL, Bökenkamp A. Cystatin C more accurately detects mildly impaired renal function than creatinine in children receiving treatment for malignancy. Pediatric Blood \& Cancer 2011; 57(2): 262-267.

80. Bacchetta J, Cochat P, Rognant N, Ranchin B, Hadj-Aissa A, Dubourg L. Which Creatinine and Cystatin C Equations Can Be Reliably Used in Children? CJASN March 2011; 6(3): 552-60.

81. Pöge U, Stoschus B, Stoffel-Wagner B, Gerhardt T, Klehr HU, Sauerbruch T, Woitas RP. Cystatin $\mathrm{C}$ as an endogenous marker of glomerular filtration rate in renal transplant patients. Kidney Blood Press Res 2003; 26(1): 55-60.

82. Risch L, Blumberg A, Huber A. Rapid and accurate assessment of glomerular filtration rate in patients with renal transplants using serum cystatin C. Nephrol Dial Transplant 1999; 14: 1991-6.

83. Le Bricon T, Thervet E, Froissart M,Benlakehal M, Bousquet B, Legendre C, Erlich D. Plasma Cystatin C Is Superior to 24-h Creatinine Clearance and Plasma Creatinine for Estimation of Glomerular Filtration Rate 3 Months after Kidney Transplantation Clinical Chemistry 2000; 46: 1206-7.

84. Bökenkamp A, Domanetzki M, Zinck R, Schumann G, Byrd D, Brodehl J. Cystatin $\mathrm{C}$ serum concentrations underestimate glomerular filtration rate in renal transplant recipients. Clin Chem 1999; 45: 1866-8. 
85. Uhlmann EJ, Hock GK, Issitt C, Sneeringer MR., Cervelli DR, Gorman RT and Scott MG. Reference Intervals for Plasma Cystatin $\mathrm{C}$ in Healthy Volunteers and Renal Patients, as Measured by the Dade Behring BN II System, and Correlation with Creatinine. Clinical Chemistry 2001; 47(11): 2031-3.

86. Hojs R, Bevc S, Ekart R, Gorenjak M and Puklavec L. Serum cystatin C as an endogenous marker of renal function in patients with mild to moderate impairment of kidney function. Nephrology Dialysis Transplantation 2006; 21(7): 1855-62.

87. White CA, Akbari A. The Estimation, Measurement, and Relevance of the Glomerular Filtration Rate in Stage 5 Chronic Kidney Disease. Seminars in Dialysis 2011; 24:(5): 540-9.

88. Tan GD, Lewis AV, James TJ, Altmann P, Taylor RP, Levy JC. Clinical Usefulness of Cystatin $\mathrm{C}$ for the Estimation of Glomerular Filtration Rate in Type 1 Diabetes: Reproducibility and accuracy compared with standard measures and iohexol clearance. Diabetes Care 2002; 25: 2004-9.

89. Olusegun A, Abdella $\mathrm{M}$ and Abdella N. Evaluation of cystatin $\mathrm{C}$ and $\beta-2$ microglobulin as markers of renal function in patients with type 2 diabetes mellitus. Journal of Diabetes and its Complications 2003; 17(3): 160-8.

90. Strevens H, Wide-Swensson D, Torffvit O, Grubb A. Serum cystatin C for assessment of glomerular filtration rate in pregnant and non-pregnant women. Indications of altered filtration process in pregnancy. Scand J Clin Lab Invest 2002; 62(2): 141-7.

91. Tangri N, Stevens LA, Schmid CH, Zhang YL, Beck GJ, Greene T, Coresh J, Levey Changes in dietary protein intake has no effect on serum cystatin $\mathrm{C}$ levels independent of the glomerular filtration rate. AS. Kidney Int 2011; 79(4): 471-7.

92. Grubb A, Björk J, Nyman U, Pollak J, Bengzon J, Ostner G, Lindström V. Cystatin C, a marker for successful aging and glomerular filtration rate, is not influenced by inflammation. Scand J Clin Lab Invest 2011; 71(2): 145-9.

93. Sokol JP, Schiemann WP. Cystatin C antagonizes transforming growth factor beta signalling in normal and cancer cells. Mol Cancer Res 2004; 2: 183-95. 
94. Peter W, Beat S, Gianten AS, Christoph S. Serum cystatin C is sensitive to small changes in thyroid function. Clinica Chimica Acta 2003; 338: 87-90.

95. Dharnidharka VR, Kwon C, Stevens G. Serum cystatin C is superior to serum creatinine as a marker of kidney function: a meta-analysis. Am J Kidney Dis 2002; 40: 221-6.

96. Li J, Dunn W, Breaud A, Elliott D, et al. Analytical performance of 4 automated assays for measurement of cystatin C. Clin Chem 2010; 56: 1336-9.

97. Larsson A, Hansson L-O, Flodin M, Katz R, Shlipak MG. Calibration of the Siemens cystatin C immunoassay has changed over time. Clin Chem 2011; 57 : $777-8$.

98. Grubb A, Blirup-Jensen S, Lindström V, Schmidt C, et al. First certified reference material for cystatin $\mathrm{C}$ in human serum ERM-DA471/IFCC. Clin Chem Lab Med 2010; 48: 1619-21.

99. Dajak M, Ignjatović S, Majkić-Singh N. Funkcija bubrega- procena brzine glomerularne filtracije. JMB 2007; 26: 51-7.

100. Inker LA, Aghogho O. Cystatin $\mathrm{C}$ as a marker of glomerular filtration rate: prospects and limitations. Current Opinion in Nephrology \& Hypertension 2011; 20(6): 631-9.

101. Jakšić E, Artiko V, Beatović S, Đokić D, Janković D, Šobić Šaranović D et al. Clinical investigations of ${ }^{99 \mathrm{~m}} \mathrm{Tc}$-p-aminohippuric acid as a new renal agent. Nuclear Nedicine Communications 2009; 30: 76-81.

102. Ocampo HJ, Rosales TA, Castellanos RF. Comparison of four methods for measuring glomerular filtration rate by inulin clearance in healthy individuals and patients with renal failure. Nefrologia 2010; 30(3): 324-30.

103. Rehling M, Moller ML, Thamdrup B, Lund JO, Trap-Jensen J. Simultaneous measurement of renal clearance and plasma clearance of $99 \mathrm{mTc}$-labelled diethylenetriaminepenta-acetate, 51Cr-labelled ethylenediaminetetra-acetate and inulin in man. Clin Sci 1984; 66: 613-9.

104. LaFrance ND, Drew HH, Walser M. Radioisotopic Measurement of Glomerular Filtration Rate in Severe Chronic Renal Failure. J Nuc Med 1988; 29: $1927-30$.

105. Damman K, van der Harst P, Smilde TDJ, Voors AA, Navis G, van Veldhuisen JD, Hillege LH. Use of cystatin $\mathrm{C}$ levels in estimating renal function and 
prognosis in patients with chronic systolic heart failure. Heart 2012; 98: 31924.

106. Filler G, Bokenkamp A, Hofmann W, Le Bricon T, Martinez-Bru C, Grubb A. Cystatin $\mathrm{C}$ as a marker of GFR-history, indications, and future research. Clin Biochem 2005; $38: 1-8$.

107. Randers E, Kristensen JH, Erlandsen EJ, Danielsen H. Serum cystatin C as a marker of the renal function. Scand J Clin Lab Invest 1998; 58: 585-592.

108. Kim JD et al. Cystatin C in patients with cirrhotic ascites. Korean J Hepatol 2011; 17: 130-8.

109. Rule AD, Bergstralh EJ, Slezak JM, Bergert J, Larson TS. Glomerular filtraton rate estimated by cystatin $\mathrm{C}$ among different clinical presentations. Kidney Int 2006; 69: 399-405.

110. Filler G, Priem F, Lepage N, Sinha P, Vollmer I, Clark H, Keely E, Matzinger M, Akbari A, Althaus H, Jung K. Beta-trace protein, cystatin C, beta(2)microglobulin, and creatinine compared for detecting impaired glomerular filtration rates in children. Clin Chem 2002; 48(5): 729-36

111. Kasiske BL, Umen AJ. The influence of age, sex, race, and body habitus on kidney weight in humans. Arch Pathol Lab Med 1986; 110: 55-60.

112. Ahmed SB, Bentley-Lewis R, Hollenberg NK, Graves SW, Seely EW. A comparison of prediction equations for estimating glomerular filtration rate in pregnancy. Hypertens Pregnancy 2009; 28: 243-55.

113. Conrad K. Mechanisms of renal vasodilation and hiperfiltration during pregnancy. Journal of the Society for Gynecologic Investigation 2004; 7: 43843.

114. Larsson A, Palm M, Hansson L, Axelsson O. Reference values for clinical chemistry tests during normal pregnancy. BJOG 2008; 115: 874-81.

115. Finney H, Newman D.J and Price CP. Adult reference ranges for serum cystatin $\mathrm{C}$, creatinine and predicted creatinine clearance. Ann Clin Biochem 2000; 37: 49.

116. Bramham K, Kakanjuola D, Hussein W, Cafful D, Shehata H.Serum cystatin is not a marker of glomerular filtration rate in pregnancy. Obstet Med 2009; 2: $121-2$. 
117. Girling C. J. Re-evaluation of plasma creatinine concentration in normal pregnancy. Journal of Obstetrics \& Gynaecology 2000; 20(2): 128-31

118. Dajak M. Klinička vrednost beta-trace protein kao biomarkera hronične bolesti bubrega. Doktorska disertacija. Farmaceutski fakultet, Beograd 2011.

119. Akbari A, Filler G, Keely E, Clark HD, Mackinnon M, Lepage N. Measurement of small molecular weight proteins as markers of GFR in pregnancy. J Am Soc Nephrol 2002; 13: 420A.

120. Abbassi-Ghanavati M, Greer LG, Cunningham FG. Pregnancy and laboratory studies: a reference table for clinicians. Obstet Gynecol 2009; 114(6): 1326-31.

121. Davison JM, Dunlop W: Changes in renal hemodynamics and tubular function induced by normal pregnancy. Semin Nephrol 1984; 4: 198-207.

122. Linheimer MD, Katz AI. Renal physiology and disease in pregnancy. In Seldin DW, Giebisch G (eds): The Kidney: Physiology and Pathophysiology, pp 3d ed. Philadelphia, Lippincott Williams and Wilkins 2000.

123. Galteau MM, Guyon M, Gueguen R, Siest G. Determination of serum cystatin C: biological variation and reference values. Clin Chem Lab Med 2001; 39: $850-57$.

124. Weinert LS, Prates AB, do Amaral FB, Vaccaro MZ, Camargo JL, Silveiro SP. Gender does not influence cystatin $\mathrm{C}$ concentrations in healthy volunteers. Clin Chem Lab Med 2010; 48(3): 405-8.

125. Erlandsen EJ, Randers E, Kristensen JH. Reference intervals for serum cystatin C and serum creatinine in adults. Clin Chem Lab Med 1998; 36(6): 393-7.

126. Ognibene A, Mannucci E, Caldini A, Terreni A, Brogi M, Bardini G, Sposato I, Mosconi V, Salvadori B, Rotella CM, Messeri G. Cystatin C reference values and aging. Clin Biochem 2006; 39(6): 658-61.

127. Fischer MJ. Chronic kidney disease and pregnancy: Maternal and fetal outcomes. Adv Chronic Kidney Dis 2007; 14: 132-45.

128. Cataldi L, Mussap M, Bertelli L, Ruzzante N, Fanos V, Plebani M.Cystatin C in healthy women at term pregnancy and in their infant newborns: relationship between maternal and neonatal serum levels and reference values. Am J Perinatol 1999; 16(6): 287-95. 
129. Akbari A, Lepage N, Keely E, Clark HD, Jaffey J, MacKinnon M, Filler G.. Cystatin- $\mathrm{C}$ and beta trace protein as markers of renal function in pregnancy. BJOG 2005; 112(5): 575-8.

130. Kristensen K, Lindstrom V, Schmidt C, Blirup-Jensen S, Grubb A, WideSwenson D, Stevens H. Temporal changes of the plasma levels of cystatin C, $\beta$-trace protein, $\beta 2$-microglobulin, urate and creatinine during pregnancy indicate continuous alterations in the renal filtration process. Scand J Clin Lab Invest 2007; 67: 612-8.

131. Bramham K, Kakanjuola D, Hussein W, Cafful D, Shehata H. Serum cystatin is not a marker of glomerular filtration rate in pregnancy. Obstet Med 2009; 2: $121-2$.

132. All Wakeel SJ, Mamon AN, Choudhary RA, Mitwalli HA, Tarif N, Isnani A, Hammad D. Normal reference levels of serum cystatin C in Saudi Adults. Saudi J Kidney Dis Transpl 2008; 19(3): 361-70.

133. Knight EL, Verhave JC, Spiegelman D, Hillege HL, deZeeuw D, Curhan GC, deJong PE. Factors influencing cystatin $\mathrm{C}$ levels other than renal function and the impact on renal function measurement. Kidney Int 2004; 65: 1416-21.

134. Saxena RA, Karumanchi AS, Fan LF, Horowitz LG, Hollenberg KN, Graves WS et al. Correlation of Cystatin-C with Glomerular Filtration Rate by Inulin Clearance in Pregnancy. Hypertension in Pregnancy 2012; 31(1): 22-30.

135. Babay Z, Al-Wakeel J, Addar M, Mittwalli A, Tarif N, Hammad D, Ali N, AlAskar A, Choudhary RA. Serum cystatin C in pregnant women: reference values, reliable and superior diagnostic accuracy. Clin Exp Obstet Gynecol 2005; 32(3): 175-9.

136. Novo AC, Sadeck Ldos S, Okay TS, Leone CR. Longitudinal study of Cystatin $\mathrm{C}$ in healthy term newborns. Clinics (Sao Paulo) 2011; 66(2): 217-20.

137. Strevens H, Wide-Swensson D, Grubb A, Hansen A, Horn T, Ingemarsson I, et al. Serum cystatin $\mathrm{C}$ reflects glomerular endotheliosis in normal, hypertensive and pre-eclamptic pregnancies. BJOG 2003; 110: 825-30.

138. Lindheimer MD, Mahowald MB. Glomerular endotheliosis in normal pregnancy and pre-eclampsia. Br J Obstet Gynaecol 2004; 111: 191.

139. Kristensen K, Larsson I, Hansson SR. Increased cystatin C expression in the pre-eclamptic placenta. Mol Hum Reprod 2007; 13(3): 189-95. 
140. Kristensen K, Strevens H, Lindstrom V, Grubb A, Wide-Swensson D. Increased plasma levels of $\beta_{2}$-microglobulin, cystatin $C$ and $b$-trace protein in term pregnancy are not due to utero-placental production. Scand J Clin Lab Invest 2008; 68(7): 649-53.

141. Ray S, Lukyanov P, Ochieng J. Members of the cystatin superfamily interact with MMP-9 and protect it from autolytic degradation without affecting its gelatinolytic activities. Biochim Biophys Acta 2003; 1652: 91-102.

142. Obrenovic R, Petrovic D, Majkic-Singh N, Trbojevic-Stankovic J, Stojimirovic B. Serum cystatin c levels in normal pregnancy. Clin Nephrol $20116(3): 174-9$.

143. Report of the National High Blood Pressure Education Program Working Group on High Blood Pressure in Pregnancy. Am J Obstet Gynecol 2000; 183(1): S1-S22.

144. Magee LA, Helewa M, Moutquin J-M et al. Diagnosis, Evaluation, and Management of the Hypertensive Disorders of Pregnancy. Journal of Obstetrics and Gynaecology Canada 2008; 30: 1-48.

145. Chang J, Elam-Evans LD, Berg CJ, Herndon J, Flowers L, Seed KA, et al. Pregnancy-related mortality surveillance-United States, 1991-1999. MMWR Surveill Summ 2003; 52(2): 1-8.

146. Moodley J, Gangaram R, Khanyile R, Ojwang PJ. Serum cystatin C for assessment of glomerular filtration rate in hypertensive disorders of pregnancy. Hypertens Pregnancy 2004; 23(3): 309-17.

147. Franceschini N, Qiu C, Barrow AD, Williams AM. Cystatin C and preeclampsia: a case control study. Renal Failure 2008; 30(1): 89-95.

148. Thilaganathan B, Ralph E, Papageorghiou TA, Melchiorre K, Sheldon J. Raised Maternal Serum Cystatin C: An Early Pregnancy Marker for Preeclampsia. Reprod Sci 2009; 16(8): 788-93.

149. Saleh S, Antoniou A, Harrington K, Aquilina J. Second Trimester Maternal Serum Cystatin C Levels in Preeclamptic and Normotensive Pregnancies: A Small Case-Control Study. Hypertens Pregnancy 2010; 29(1): 112-9. 
150. Farag KM, Abd El Maksoud N, Ragab MH, Gaber RK. Predictive value of cystatin $\mathrm{C}$ and beta-2 microglobulin in preeclampsiaJournal of Genetic Engineering and Biotechnology 2011; 9: 133-6.

151. Strevens H, Wide-Swensson D, Grubb A. Serum cystatin C is a better marker for preeclampsia than serum creatinine or serum urate. Scand J Clin Lab Invest $2001 ; 61: 575-80$.

152. Mussap M, Fanos V, Pizzini C, Marcolongo A, Chiaffoni G, Plebani M. . Predictive value of amniotic fluid cystatin $\mathrm{C}$ levels for the early identification of fetuses with obstructive uropathies, Br J Obstet Gynerol 2002; 109: 778-83.

153. Redman CW, Sacks GP and Sargent IL. Preeclampsia: an excessive maternal inflammatory response to pregnancy. Am. J. Obstet. Gynecol. 1999; 180: 499506.

154. Greer IA, Dawes J, Johnston TA and Calder AA. Neutrophil activation is confined to the maternal circulation in pregnancy-induced hypertension. Obstet Gynecol 1991; 78: 28-32.

155. Elmarakby AA, Quigley JE, Imig JD, Pollock JS, Pollock DM. TNF- $\alpha$ inhibition reduces renal injury in DOCA-salt hypertensive rats. Am. J. Physiol. Regul. Integr. Comp. Physiol 2008; 294: 76-83.

156. Ramma W, Ahmed A. Is inflammation the cause of pre-eclampsia? Biochem Soc Trans 2011; 39(6): 1619-27.

157. Nakanishi T, Ozaki Y, Blomgren K, Tateyama H, Sugiura-Ogasawara M, Suzumori K. (2005) Role of cathepsins and cystatins in patients with recurrent miscarriage. Mol Hum Reprod 2005; 11(5): 351-355.

158. Pfohl-Leszkowicz A, Manderville RA. Ochratoxin A: An overview on toxicity and carcinogenicity in animals and humans. Mol Nutr Food Res 2007; 51(1): 61-99.

159. De Broe ME. Chinese herbs nephropathy and Balkan endemic nephropathy: toward a single entity, aristolochic acid nephropathy Kidney International 2012; 81: 513-5.

160. Hranjec T, Kovac A, Kos J, Mao W, Chen JJ, Grollman AP, Jelaković B. Endemic nephropathy: the case for chronic poisoning by aristolochia. Croat Med J 2005; 46(1): 16-25. 
161. Grollman AP, Shibutani S, Moriya M, Miller F, Wu L, Moll U, Suzuki N, Fernandes A, Rosenquist T, Medverec Z, Jakovina K, Brdar B, Slade N, Turesky RJ, Goodenough AK, Rieger R, Vukelić M, Jelaković B. Aristolochic acid and the etiology of endemic (Balkan) nephropathy. Proc Natl Acad Sci U S A. 2007; 104(29): 12129-34.

162. Djukanović L, Stefanović V, Basta-Jovanović G, Bukvić D, Glogova S, Dimitrijević $J$ et all. Investigation of Balkan endemic nephropathy in Serbia: how to proceed? Srp Arh Celok Lek 2010; 138(3-4): 256-61.

163. Stefanovic V, Polenakovic M, Toncheva D. Urothelial carcinoma associated with Balkan endemic nephropathy. A worldwide disease. Pathol Biol (Paris) 2011; 59(5): 286-91.

164. Bogićević M, Strahinjić S, Stevanović V. Protok plazme kroz bubreg i glomerulska filtracija u zdravih osoba iz porodica sa endemskom nefropatijom. In: Etology of Endemic (Balcan) Nephropathy-Proc. Of the 6 th Symp. Eds. S. Strahinjić and V. Stefanović. University Press, Niš 1987; 159-64.

165. Bukvić D, Nikolić J, Lukić L, Gluhovschi G, Toncheva D, Polenaković M, Cosyns JP: Diagnostic criteria for Balkan endemic nephropathy: proposal by an international panel. Ren Fail 2007; 29: 867-80.

166. Djukanovic L, Bukvie D. Marie I. Creatinine clearance and kidney size in Balkan endemic nephropathy patients. Clin Nephrol 2004; 61(6): 384-6.

167. Toncheva D, Galabov SA, Laich A, Atanassova S, Kamarinchev B, Dimitrov T and Fuchs D. Urinary neopterin concentrations in patients with Balkan endemic nephropathy (BEN). Kidney International 2003; 64: 1817-21.

168. Cukuranovic R, Jovanovic I, Miljkovic S, Stefanovic N, Vlajkovic S, Prokopovic M, Stefanovic V. Hemodialysis treatment in patients with Balkan endemic nephropathy: an epidemiological study. Renal Fail 2007; 29(7): 80510.

169. Mesic E, Lukic L, Dolenec L, Petkovic N, Stipancic Z, Resic H, Trnacevic S, Halilbasic A. Balkan endemic nephropathy in Bosnia and Herzegovina- renal registry report. Med Arh 2006; 60(4): 240-2. 
170. Alecković M, Mesić E, Trnacević S, Stipancić Z, Hamidović D, Hasanović E. Glomerular filtration rate in examined population of Bosnian Posavina - region of Balkan Endemic Nephropathy. Bosn J Basic Med Sci 2010; 10(1): 68-72.

171. Pakić V. Magistarska teza. Medicinski fakultet, Beograd 2010.

172. Hofstra JM, Willems JL, Wetzels JF. Estimated glomerular filtration rate in the nephrotic syndrome. Nephrol Dial Transplant 2011; 26(2): 550-6.

173. Özden TA, Palandüz A, Cahide Gökkusu A, Issever H. Serum Cystatin C Levels in Children with Nephrosis or Diabetes: A Pilot Study. The Journal of Applied Research 2004; 4(1): 135-40

174. Cho SY, Lee HJ, Suh JT, Hahn WH, Cho BS, Lee A and Suh JS. The Significance of Serum Cystatin C Accompanied by a Normal Serum Creatinine Level in Pediatric Patients With Chronic Kidney Disease. LabMedicine 2011; 42: $549-52$.

175. Obrenović R, Petrović D, Majkić-Singh N, Trbojević J, Stojimirović B. Influence of proteinuria on cystatin $\mathrm{C}$ serum concentration in patients with primary glomerulonephritis. Jugoslov Med Biohem 2006; 25 (1): 21-5

176. Branten AJ, Vervoort G, Wetzels JF: Serum creatinine is a poor marker of GFR in nephrotic syndrome. Nephrol Dial Transplant 2005; 20: 707-11.

177. Wu I, Parikh R. CH. Screening for Kidney Diseases: Older Measures versus Novel Biomarkers. CJASN 2008; 3(6): 1895-901.

178. Weinert LS, Camargo EG, Soares AA, Silveiro SP. Glomerular filtration rate estimation: Performance of serum cystatin C-based prediction equations. Clinical Chemistry and Laboratory Medicine 2011; 49(11): 1761-71.

179. Dworkin LD. Serum cystatin $\mathrm{C}$ as a marker of glomerular filtration rate. Curr Opin Nephrol Hypertens 2001; 10(5): 551-3.

180. Salgado JV, Neves FA, Bastos MG, França AK, Brito DJ, Santos EM and Salgado FN. Monitoring renal function: measured and estimated glomerular filtration rates - a review. Brazilian Journal of Medical and Biological Research (2010) 43: 528-36. 
181. Rossert JA, Wauters JP. Recommendations for the screening and management of patients with chronic kidney disease. Nephrol Dial Transplant 2002; 17(Suppl 1): 19-28.

182. Wild S, Roglic G, Green A, Sicree R, King H. Global prevalence of diabetes: Estimates for the year 2000 and projections for 2030. Diabetes Care 2004; 27: 1047-53.

183. de Boer IH, Steffes MW. Glomerular filtration rate and albuminuria: twin manifestations of nephropathy in diabetes. J Am Soc Nephrol 2007; 18: 10367.

184. Jeon YK, Kim MR, Huh JE, Mok JY, Song SH, Kim SS, Kim BH, Lee SH, Kim YK, Kim IJ. Cystatin C as an early biomarker of nephropathy in patients with type 2 diabetes. J Korean Med Sci 2011; 26(2): 258-63.

185. Rigalleau V, Lasseur C, Raffaitin C, Beauvieux MC, Barthe N, Chauveau P, Combe C, Gin H. Normoalbuminuric renal-insufficient diabetic patients: a lower-risk group. Diabetes Care 2007; 30: 2034-9

186. Perkins BA, Nelson RG, Ostrander BE, et al. Detection of renal function decline in patients with diabetes and normal or elevated GFR by serial measurements of serum cystatin $\mathrm{C}$ concentration: results of a 4-year follow-up study. J Am Soc Nephro. 2005; 16(5): 1404-12.

187. El-Shafey EM, El-Nagar GF, Selim MF, El-Sorogy HA, Sabry AA. Is serum cystatin $\mathrm{C}$ an accurate endogenous marker of glomerular filteration rate for detection of early renal impairment in patients with type 2 diabetes mellitus? Ren Fail 2009; 31(5): 355-9.

188. Vlatković V, Stojimirović B, Obrenović R, Nogić S. Tubular kidney function in patients with type 2 diabetes mellitus, microalbuminuria and proteinuria. Srp Arh Celok Lek 2007; 135(1-2): 38-42.

189. United States Renal Data System. USRDS 2010 annual data report: atlas of chronic kidney disease and end-stage renal disease in the United States. Bethesda: National Institutes of Health, National Institute of Diabetes and Digestive and Kidney Diseases; 2010. 